\title{
A phylogenetic study of the subtribe Dicrepidiina (Elateridae, Elaterinae, Ampedini)
}

\author{
Sônia A. Casari ${ }^{1,2}$ \\ ${ }^{1}$ Museu de Zoologia, Universidade de São Paulo. Caixa Postal 42494, 04218-970 São Paulo-SP, Brasil. \\ ${ }^{2}$ Pesquisadora do CNPq.
}

\begin{abstract}
A phylogenetic study of the subtribe Dicrepidiina (Elateridae, Elaterinae, Ampedini). It is presented a cladistic analysis of the Dicrepidiina aiming to test the monophyletism of the subtribe and to establish the relationships among the genera. The subtribe is composed by 36 genera and all of them, except Asebis, Lamononia, Neopsephus, Semiotopsis and Spilomorphus were included in the analysis. Fifty two species, especially the type-species of each genus were studied: Achrestus flavocinctus (Candèze, 1859), A. venustus Champion, 1895, Adiaphorus gracilis Schwarz, 1901, A. ponticerianus Candèze, 1859, Anoplischiopsis bivittatus Champion, 1895, Anoplischius bicarinatus Candèze, 1859, A. conicus Candèze, 1900, A. haematopus Candèze, 1859, A. pyronotus Candèze, 1859, Atractosomus flavescens (Germar, 1839), Blauta cribraria (Germar, 1844), Calopsephus apicalis (Schwarz, 1903), Catalamprus angustus (Fleutiaux, 1902), Crepidius flabellifer (Erichson, 1847), C. resectus Candèze, 1859, Cyathodera auripilosus Costa, 1968, C. lanugicollis (Candèze, 1859), C. longicornis Blanchard, 1843, Dayakus angularis Candèze, 1893, Dicrepidius ramicornis (Palisot de Beauvois, 1805), Dipropus brasilianus (Germar, 1824), D. factuellus Candèze, 1859, D. laticollis (Eschscholtz, 1829), D. pinguis (Candèze, 1859), D. schwarzi (Becker, 1961), Elius birmanicus Candèze, 1893, E. dilatatus Candèze, 1878, Heterocrepidius gilvellus Candèze, 1859, H. ventralis Guérin-Méneville, 1838, Lampropsephus cyaneus (Candèze, 1878), Loboederus appendiculatus (Perty, 1830), Olophoeus gibbus Candèze, 1859, Ovipalpus pubescens Solier, 1851, Pantolamprus ligneus Candèze, 1896, P. mirabilis Candèze, 1896, P. perpulcher Westwood, 1842, Paraloboderus glaber Golbach, 1990, Proloboderus crassipes Fleutiaux, 1912, Propsephus beniensis (Candèze, 1859), P. cavifrons (Erichson, 1843), Pseudolophoeus guineensis (Candèze, 1881), Rhinopsephus apicalis (Schwarz, 1903), Sephilus formosanus Schwarz, 1912, S. frontalis Candèze, 1878, Singhalenus gibbus Candèze, 1892, S. taprobanicus Candèze, 1859, Sphenomerus antennalis Candèze, 1859, S. brunneus Candèze, 1865, Spilus atractomorphus Candèze, 1859, S. nitidus Candèze, 1859, Stenocrepidius simonii Fleutiaux, 1891 and Trielasmus varians Blanchard, 1846. Chalcolepidius zonatus (Hemirhipini, Agrypninae), Ctenicera silvatica (Prosternini, Prosterninae), and species of the other subtribes of Ampedini (Elaterinae): Ampedus sanguineus (Ampedina), Melanotus spernendus (Melanotina) and Anchastus digittatus and Physorhinus xanthocephalus (Physorhinina) were used as outgroups. The results of the phylogenetic analysis demonstrated that Dicrepidiina, as formerly defined, does not form a monophyletic group. One genus, represented by Ovipalpus pubescens, was removed from the subtribe. The subtribe is characterized by presence of lamella under $2^{\text {nd }}$ and $3^{\text {rd }}$ tarsomeres of all legs. Also, it was revealed that the genera Achrestus, Anoplischius, Dipropus and Propsephus are not monophyletic. Due to the scarcity of information, all the studied species are redescribed and illustrated.
\end{abstract}

KEYWORDS. Ampedina; Hemirhipini; Melanotina; Physorhinina; Prosternini.

RESUMO. Estudo filogenético da subtribo Dicrepidiina (Elateridae, Elaterinae, Ampedini). Neste trabalho é apresentada uma análise cladística de Dicrepidiina visando testar o monofiletismo da subtribo e estabelecer as relações entre os gêneros. A subtribo está formada por 36 gêneros e todos, exceto Asebis, Lamononia, Neopsephus, Semiotopsis e Spilomorphus foram incluídos na análise. Foram estudadas 52 espécies, principalmente as espécies-tipo de cada gênero: Achrestus flavocinctus (Candèze, 1859), A. venustus Champion, 1895, Adiaphorus gracilis Schwarz, 1901, A. ponticerianus Candèze, 1859, Anoplischiopsis bivittatus Champion, 1895, Anoplischius bicarinatus Candèze, 1859, A. conicus Candèze, 1900, A. haematopus Candèze, 1859, A. pyronotus Candèze, 1859, Atractosomus flavescens (Germar, 1839), Blauta cribraria (Germar, 1844), Calopsephus apicalis (Schwarz, 1903), Catalamprus angustus (Fleutiaux, 1902), Crepidius flabellifer (Erichson, 1847), C. resectus Candèze, 1859, Cyathodera auripilosus Costa, 1968, C. lanugicollis (Candèze, 1859), C. longicornis Blanchard, 1843, Dayakus angularis Candèze, 1893, Dicrepidius ramicornis (Palisot de Beauvois, 1805), Dipropus brasilianus (Germar, 1824), D. factuellus Candèze, 1859, D. laticollis (Eschscholtz, 1829), D. pinguis (Candèze, 1859), D. schwarzi (Becker, 1961), Elius birmanicus Candèze, 1893, E. dilatatus Candèze, 1878, Heterocrepidius gilvellus Candèze, 1859, H. ventralis Guérin-Méneville, 1838, Lampropsephus cyaneus (Candèze, 1878), Loboederus appendiculatus (Perty, 1830), Olophoeus gibbus Candèze, 1859, Ovipalpus pubescens Solier, 1851, Pantolamprus ligneus Candèze, 1896, P. mirabilis Candèze, 1896, P. perpulcher Westwood, 1842, Paraloboderus glaber Golbach, 1990, Proloboderus crassipes Fleutiaux, 1912, Propsephus beniensis (Candèze, 1859), P. cavifrons (Erichson, 1843), Pseudolophoeus guineensis (Candèze, 1881), Rhinopsephus apicalis (Schwarz, 1903), Sephilus formosanus Schwarz, 1912, S. frontalis Candèze, 1878, Singhalenus gibbus Candèze, 1892, S. taprobanicus Candèze, 1859, Sphenomerus antennalis Candèze, 1859, S. brunneus Candèze, 1865, Spilus atractomorphus Candèze, 1859, S. nitidus Candèze, 1859, Stenocrepidius simonii Fleutiaux, 1891 e Trielasmus varians Blanchard, 1846. Como grupos externos foram usados Chalcolepidius zonatus (Hemirhipini, Agrypninae), Ctenicera silvatica (Prosternini, Prosterninae), e algumas espécies de outras subtribos de Ampedini (Elaterinae): Ampedus sanguineus (Ampedina), Melanotus spernendus (Melanotina) e Anchastus digittatus e Physorhinus xanthocephalus (Physorhinina). Os resultados da análise filogenética demonstraram que Dicrepidiina, como definida anteriormente, não forma um grupo monofilético. Um gênero, representado por Ovipalpus pubescens, foi removido da subtribo. A subtribo está caracterizada pela presença de lamela no $2^{\circ}$ e $3^{\circ}$ tarsômeros de todas as pernas. Também está evidente que os gêneros Achrestus, Anoplischius, Dipropus e Propsephus não são monofiléticos. Devido à falta de informações sobre o grupo, todas as espécies estudadas são redescritas e ilustradas.

PALAVRAS-CHAVE. Ampedina; Hemirhipini; Melanotina; Physorhinina; Prosternini. 
The subfamily Elaterinae is composed by 6 tribes: Elaterini, Megapenthini, Pomachilini, Ampedini, Eudicronychini and Odontonychini. The tribe Ampedini is divided into 4 subtribes: Ampedina, Physorhinina, Dicrepidiina and Melanotina (Johnson 2002a).

The subtribe Dicrepidiina is a group very rich in species and recorded from every tropical area of the world. It includes 36 genera and about 1,520 species. They are usually recognized by at least $2^{\text {nd }}$ and $3^{\text {rd }}$ tarsomeres lamellate beneath and frons carinate with nasal plate high. The coloration is not attractive, usually they are brown uniform and pubescent. The notosternal sutures are short, grooved and curved.

In this work it is presented the cladistic analysis of Dicrepidiina aiming to test the monophyletism of the subtribe and to verify the relationships among the genera. It was included as many species as available for each analysed genus, and at least the type-species of each, when possible, was studied.

To increase the knowledge of the group, the historical review and the list of species (except for Anoplischius, Dipropus and Propsephus) of each genus and the redescriptions and illustrations of all studied species are also presented.

Historical review. Lacordaire (1857) divided the "Élatérides" in 8 tribes. He included in the Tribe VII, the "Élatérides Vrais", divided in two groups according to the presence or absence of the frontal carina. The genera with frontal carina, Piezophilus Hope, 1842, Aemidius Latreille, 1834, Lobederus [sic] Guérin-Méneville, 1831, Heterocrepidius Guérin-Méneville, 1838, Atractosomus Lacordaire, 1857, Pomachilius Eschscholtz, 1829, Physorhinus Eschscholtz, 1836, Anchastus LeConte, 1853, Brachycrepis LeConte, 1853, Monocrepidius Eschscholtz, 1829, Pityobius LeConte, 1853 and Pedetes Kirby, 1837 were in the subdivision "Tarses munis de lamelles". He presented a key to genera and stated that these genera were erected based on the number of lamellae of tarsi: the Trielasmus Blanchard, 1846 presents the three first tarsomeres lamellate; the Blauta LeConte, 1853 also, but the lamellae are from tarsomeres 2-4 [in fact, the tarsi are 4- lamellate]. The majority has two lamellae under tarsomeres 2-3 and Eschscholtz (1829) included all in Dicrepidius Eschscholtz, 1829, but there is some American species with triangular nasal plate, opened antennal cavities and flabellate antennae in males that are not congeneric. The Heterocrepidius "vrais" are characterized by presence of lamellae under tarsomeres 2-3 of anterior and median tarsi and only tarsomere 3 of posterior tarsi.

Candèze (1859) in "Dicrépidiites" redescribed 6 genera (Aemidius, Atractosomus, Dicrepidius, Heterocrepidius, Loboederus Guérin-Méneville, 1831, Piezophyllus Hope, 1842) and erected 11: Adiaphorus, Anoplischius, Crepidius, Elius, Ischiodontus, Olophoeus, Pantolamprus, Psephus, Singhalenus, Sphenomerus and Spilus. These genera were separate into two groups according to the shape of borders of mesosternal cavity. He presented identification key to genera and species.
Candèze (1865) erected the genus Anathesis and described 7 species belonging to 5 genera.

Candèze (1891) catalogued 25 genera to "Tribu VI. Dicrépidiites", including the 17 genera treated in 1859 (except Atractosomus, considered as synonym of Atractodes Germar,1839), besides Anathesis Candèze, 1865 (later transferred to Agrypninae, Agrypnini), Coresus Candèze, 1891 (later transferred to Tetralobinae), Cyathodera Blanchard, 1846, Ovipalpus Solier, 1851, Sephilus Candèze, 1878, Sossor Candèze, 1883 (later transferred to Denticollinae, Senodonini), Tarsalgus Candèze, 1881 (later transferred to Elaterinae, Eudicronychini) and Trielasmus.

Candèze (1893) erected the genus, Dayakus, and described 11 species belonged to 6 other genera.

Champion (1894) included in the "Group Dicrepidiini", Anoplischius, Atractosomus, Crepidius, Dicrepidius, Heterocrepidius, Ischiodontus, Spilus and two new genera, Anoplischiopsis and Spilomorphus.

Schwarz (1906) presented a key to 28 genera of Dicrepidiini: Adiaphorus, Aemidius (later transferred to Elaterinae, Elaterini), Anoplischiopsis, Asebis, Atractosomus, Crepidius, Coresus (later transferred to Tetralobinae), Dayakus, Dicrepidius, Elius, Heterocrepidius, Ischiodontus, Odontonychus (Candèze, 1896), Loboederus, Olophoeus (Subgen. Cyathodera), Ovipalpus, Pantolamprus, Piezophylus (later transferred to Tetralobinae), Psephus, Rhinopsephus, Semiotopsis, Singhalenus, Sossor (later transferred to Denticollinae, Senodonini), Sphenomerus, Sephilus, Spilomorphus, Spilus and Stenocrepidius.

Hyslop (1917) presented a phylogeny of the Elateridae based on larval characters and included the subtribes Elaterina and Dicrepidiina in the tribe Elaterini of the subfamily Elaterinae. He studied the larva of Ischiodontus oblitus Candèze and characterized Dicrepidiina by transverse muscular impressions of abdomen obliquely placed upon the tergites.

Schenkling (1925) catalogued 33 genera for the subfamily Dicrepidiinae, including the same genera catalogued by Candèze (1891) except Dicronychus, Tarsalgus, Anathesis and also including Aemidioides Fleutiaux, 1922, Anoplischiopsis, Asebis Candèze, 1894, Dayakus, Odontonychus, Proloboderus Fleutiaux, 1912, Rhinopsephus Schwarz, 1906, Semiotopsis Candèze, 1887, Spilomorphus, Stenocrepidius Schwarz, 1902 and Subathous Fleutiaux, 1918. Besides, the name Propsephus Hyslop 1921, replaced Psephus and Atractosomus replaced Atractodes, both preoccupied, and Cyathodera was considered as subgenus of Anoplischius.

Fleutiaux (1928) in the study of the elaterids from "Indochine Française", amplified the characterization of the subfamily Dicrepidiinae and presented a generic key to Elius, Singhalenus, Sphenomerus and a new genus, Lampropsephus.

Fleutiaux (1935a) included in Dicrepidiinae: Piezophyllus (later included in Tetralobini), Olophoeus, Propsephus and also a new genus, Eupsephus (later synonymyzed under Dayakus). In this same year (1935b) described Xantholamprus, a subgenus to Pantolamprus. 
Blackwelder (1944) catalogued 15 genera to Dicrepidiina: Anoplischiopsis, Anoplischius, Atractosomus, Crepidius, Dicrepidius, Heterocrepidius, Ischiodontus, Lobaederus [sic], Ovipalpus, Proloboderus, Semiotopsis, Spilomorphus, Spilus, Stenocrepidius and Trielasmus.

Basilewsky (1958) studying the Dicrepidiinae from "Congo Belge", erected two genera, Catalamprus and Calopsephus, synonymized Eupsephus under Dayakus and presented a key to 9 genera: Calopsephus, Catalamprus, Dayakus, Odontonychus (later transferred to Odontonychini), Olophoeus, Pantolamprus, Piezophyllus (later transferred to Tetralobini), Propsephus and Rhinopsephus. He followed Dicrepidiinae sensu Schwarz (1906) with some modifications.

Van Zwaluwenburg (1959) designated some lectotypes of Pacific Elateridae including some Dicrepidiinae belonged to genera Sephilus and Propsephus. He also commented about the position of Sossor, belonged to subfamily Senodoniinae. According to him, this genus was formerly included in the Dicrepidiinae because of inaccurate description of the tarsal structure, but Fleutiaux (1936) assigned it correctly in Senodoniinae.

Crowson (1960) presented a key to Elateridae subfamilies including also the characters of the tip of hindwing, in Elaterinae with two sclerotisations.

Cobos (1970) studying the "faune du Congo (Brazzville)" included in Dicrepidiinae: Pantolamprus, Dayakus, Propsephus, Rhinopsephus and Calopsephus.

Girard (1971) in your paper about "Les Coléoptères de Lamto (Côte d'Ivoire)" stated that Dicrepidiina are very common, specially collecting at night. He collected, at light, hundreds of specimens belonged to 4 genera and 25 species, from which 10 new species. He also erected a genus, Pseudolophoeus.

Dolin (1975) based on the wing venation, discussed about its significance in the taxonomy of the family and presented a key to subfamilies. He presented a characterization to the subfamily Elaterinae Leach, 1815, based on wing, larva and adult, and included in Dicrepidiini 13 genera: Anoplischiopsis, Anoplischius, Crepidius, Cyathodera, Dicrepidius, Heterocrepidius, Ischiodontus, Loboederus, Odontonychus (later transferred to Odontonychini), Olophoeus, Pantolamprus, Propsephus and Singhalenus.

Gurjeva (1974) studying the thoracic structure of click beetles presented a key to subfamilies and characterized and illustrated the thorax of each one. He incorporated in the subfamily Elaterinae 7 tribes including Dicrepidiini with Dicrepidius, Elius, Ischiodontus and Pantolamprus. About Dicrepidiini he stated "The last-mentioned tribe is clearly composite".

Smith \& Enns (1977) presented a key to subfamilies, tribes and genera of Missouri Elateridae. From Dicrepidiini (Elaterinae) he treated of Dicrepidius and Dipropus.

Stibick (1979) presented the relationships of the Elateridae subfamilies and tribes, based on adult and larval characters. He included in Elaterinae, besides Dicrepidiini, also Odontonychyni, Ampedini, Megapentini, Physorhinini,
Adrastini, Pomachilini, Agriotini and Elaterini and presented a key to these tribes.

Johnson (2002b) presented a classification of the Elateridae genera of Mexico and Central America where he included in the subtribe Dicrepidiina 11 genera: Achrestus, Anoplischiopsis, Anoplischius, Atractosomus, Crepidius, Cyathodera, Dicrepidius, Dipropus, Heterocrepidius, Spilomorphus and Spilus.

Currently, the subtribe Dicrepidiina is formed by the following genera: Achrestus, Adiaphorus, Anoplischiopsis, Anoplischius, Asebis, Atractosomus, Blauta, Calopsephus, Catalamprus, Crepidius, Cyathodera, Dayakus, Dicrepidius, Dipropus, Elius, Heterocrepidius, Lamononia, Lampropsephus, Loboederus, Neopsephus, Olophoeus, Ovipalpus, Pantolamprus, Paralobederus, Proloboderus, Propsephus, Pseudolophoeus, Rhinopsephus, Semiotopsis, Sephilus, Singhalenus, Sphenomerus, Spilomorphus, Spilus, Stenocrepidius, Trielasmus.

\section{MATERIAL AND METHODS}

The material studied belongs to following institutions (curator parenthesized): DZUP: Coleção de Entomologia Pe. J. S. Moure, Departamento de Zoologia, Curitiba, Paraná, Brazil (L. M. Almeida); FSCA: Florida State Collection of Arthropods, Gainesville, U.S.A. (M.C. Thomas); IMLA: Instituto Miguel Lillo, Tucuman, Argentina (S. Aranda); ISNB: Institut Royal des Sciences Naturelles de Belgique, Brussels, Belgium (P. Grootaert); IBSP: Instituto Biológico de São Paulo, São Paulo, Brazil (S. Ide); MNHN: Museum National d'Histoire Naturelle, Paris, France (C. Girard); MZSP: Museu de Zoologia, Universidade de São Paulo, São Paulo, Brazil (S. Casari).

All genera of the subtribe, except Asebis, Lamononia, Neopsephus, Semiotopsis and Spilomorphus were studied. When possible, at least the type-species of each genera were analysed. The following species were studied: Achrestus flavocinctus (Candèze, 1859), A. venustus Champion, 1895, Adiaphorus gracilis Schwarz, 1901, A. ponticerianus Candèze, 1859, Anoplischiopsis bivittatus Champion, 1895, Anoplischius bicarinatus Candèze, 1859, A. conicus Candèze, 1900, A. haematopus Candèze, 1859, A. pyronotus Candèze, 1859, Atractosomus flavescens (Germar, 1839), Blauta cribraria (Germar, 1844), Calopsephus apicalis (Schwarz, 1903), Catalamprus angustus (Fleutiaux, 1902), Crepidius flabellifer (Erichson, 1847), C. resectus Candèze, 1859, Cyathodera auripilosus Costa, 1968, C. lanugicollis (Candèze, 1859), C. longicornis Blanchard, 1843, Dayakus angularis Candèze, 1893, Dicrepidius ramicornis (Palisot de Beauvois, 1805), Dipropus brasilianus (Germar, 1824), D. factuellus Candèze, 1859, D. laticollis (Eschscholtz, 1829), D. pinguis (Candèze, 1859), D. schwarzi (Becker, 1961), Elius birmanicus Candèze, 1893, E. dilatatus Candèze, 18578, Heterocrepidius gilvellus Candèze, 1859, H. ventralis Guérin-Méneville, 1838, Lampropsephus cyaneus (Candèze, 1878), Loboederus appendiculatus (Perty, 1830), Olophoeus gibbus Candèze, 1859, Ovipalpus pubescens Solier, 1851, Pantolamprus 
ligneus Candèze, 1896, P. mirabilis Candèze, 1896, $P$. perpulcher Westwood, 1842, Paraloboderus glaber Golbach, 1990, Proloboderus crassipes Fleutiaux, 1912, Propsephus beniensis (Candèze, 1859), P. cavifrons (Erichson, 1843), Pseudolophoeus guineensis (Candèze, 1881), Rhinopsephus apicalis (Schwarz, 1903), Sephilus formosanus Schwarz, 1912, S. frontalis Candèze, 1878, Singhalenus gibbus Candèze, 1892, S. taprobanicus Candèze, 1859, Sphenomerus antennalis Candèze, 1859, S. brunneus Candèze, 1865, Spilus atractomorphus Candèze, 1859, S. nitidus Candèze, 1859, Stenocrepidius simonii Fleutiaux, 1891 and Trielasmus varians Blanchard, 1846. All these species were redescribed because the majority of them present only the original description, frequently very succinct.

As out groups were used Chalcolepidius zonatus Eschscholtz, 1829 (Hemirhipini, Agrypninae) Ctenicera silvatica (Van Dyke, 1932)(Prosternini, Prosterninae) and the followings Ampedini (Elaterinae): Ampedus sanguineus (Linnaeus, 1758)(Ampedina), Melanotus spernendus Candèze, 1873 (Melanotina) and Anchastus digittatus LeConte, 1853 and Physorhinus xanthocephalus Germar, 1840 (Physorhinina).

In the historical review of each genus it is presented a list of species included in the genus except for Anoplischius, Dipropus and Propsephus, that are formed by, respectively, about 110, 150 and 380 species. The large number of species did not permit to write down all them. Before the species redescriptions is presented the position and the characterization of each genus based on the present analysis. When only one species was studied, the discussion is based on this species that suggests the genus position.

The redescriptions of Blauta cribraria, Loboederus appendiculatus and Chalcolepidius zonatus are very succinct, restricted to characters included in the analysis. A very complete redescription is found, respectively, in Casari (2005, 2004, 2002).

The following abbreviations were used: D (dorsal), ex. (exemplar), F (female), L (lateral), M (male), V (ventral).

Cladistic analysis. Seventy eight characters were selected, most of which are based on external morphology. Multistate characters were used, always being treated as unordered. Fifty two taxa were included in the data matrix as representatives of various groups accepted in Dicrepidiina and six from other subtribes or tribes (out groups).

The matrix (Table 1) was edited by Nexus program, version 0.5.0 (Page 2001) and the missing data were represented by "?" and the innaplicable characters by "-". The trees were conducted using the TNT program (Goloboff et al. 2003), and represented through Winclada version 1.00.08 (Nixon 2002), with optimization "unambig changes only". All characters are treated initially as unweighted. The trees were rooted a posteriori (Nixon \& Carpenter 1993), in Chalcolepidius. The analyses were conducted based on 20000 random addition sequences with 2 trees save per replication. The swapping algorithm used was tree bisection reconnection (TBR).
In a second analysis the characters were weighted using successive weighting, giving the highest weight to those characters which have the highest fit (Goloboff 1993; Goloboff et al. 2003). It was tested fits 5, 10, 15, 20, 25, 30, 40 and 50.

\section{Characters.}

0. Frons (CI 0.16, RI 0.66: (0) wider than long; (1) longer than wide; (2) as wide as long.

1. Frontal carina (CI 0.66, RI 0.80): (0) complete; (1) absent; (2) incomplete.

2. Anterior margin of frons (CI 0.26, RI 0.42): (0) declivous at middle; (1) rounded; (2) prominent at middle; (3) straight; (4) prominent and rounded at middle.

3. Anterior margin of frons (CI 0.25, RI 0.57): (0) at nasal level; (1) prominent; (2) strongly prominent; (3) fused to nasal; (4) at nasal level at middle.

4. Median anterior region of frons (CI 0.28, RI 0.58): (0) convex; (1) concave; (2) stronlgy convex; (3) grooved at middle; (4) downwards.

5. Nasal (CI 1.00, RI 1.00): (0) present; (1) absent.

6. Ridge of nasal (CI 0.50, RI 0.00): (0) present (Figs. 155, 156); (1) absent.

7. Nasal size (CI 0.37, RI 0.64): (0) wider than long; (1) longer than wide; (2) as wide as long; (3) very narrow, almost absent at middle.

8. Antennae of male (CI 0.31, RI 0.43): (0) filiform (Fig. 5); (1) serrate (Fig. 3); (2) subserrate (Fig. 16); (3) flabellate (Fig. 4); (4) serrate in both sides (Fig. 27); (5) strongly serrate (Fig. 23); (6) serrate wide (Fig. 33).

9. Antennae of female (CI 0.28, RI 0.37): (0) filiform; (1) serrate; (2) subserrate; (3) serrate in both sides; (4) pectinate; (5) serrate wide.

10. Antennomeres shape (CI 1.00, RI 1.00): (0) cylindrical; (1) flattened.

11. Length of scape in relation to eye (CI 0.33, RI 0.00): (0) shorter; (1) same length; (2) longer.

12. Shape of antennomere 2 (CI 1.00, RI 1.00): (0) globular (Fig.3); (1) transverse (Fig. 37).

13. Shape of antennomere 3 of male (CI 0.53, RI 0.50): (0) elongate, cylindrical (Fig. 5); (1) triangular (Fig. 3); (2) subtrapezoidal (Fig. 37); (3) elongate, short (Fig. 11); (4) globular (Fig. 36); (5) elongate, triangular (Fig. 15); (6) flabellate (Fig. 4); (7) triangular and prominent laterally (Fig. 23).

14. Antennomere 3 (CI 0.20, RI 0.20): (0) longer than 4 (Fig. 30); (1) shorter than 4 (Fig. 7); (2) as long as 4 (Fig. 13).

15. Length of antennae of male in relation to hind angles of pronotum (CI 0.18, RI 0.50): (0) until 2.4 antennomeres longer; (1) 2.5-4.4 antennomeres longer; (2) more than 4.5 antennomeres longer; (3) not reaching hind angles apices.

16. Longitudinal carina of antennae (CI 0.50, RI 0.50): (0) present (Fig. 12); (1) absent (Fig.3); (2) incomplete (Fig. 22).

17. Longitudinal smooth band of antennae (CI 1.00, RI 1.00): (0) present; (1) absent. 
18. Labrum (CI 0.19, RI 0.30): (0) semielliptical (Fig. 66); (1) semicircular (Figs. 56, 63); (2) subtrapezoidal (Fig. 68); (3) subrectangular (Fig. 65); (4) elliptical narrowed at base (Fig. 58); (5) narrow band-like (Fig. 71).

19. Anterior margin of labrum (CI 0.33, RI 0.27): (0) rounded (Fig. 54); (1) notched at middle (Fig. 56); (2) sinuous (Fig. 92); (3) trapezoidal (Fig. 68); (4) straight (Fig. 65).

20. Mandibles (CI 0.28, RI 0.73): (0) wide (Fig. 101); (1) narrow (Fig. 103); (2) quadrangular (Fig. 137).

21. Mesal area of mandibles (CI 0.41, RI 0.65): (0) with one apical tooth (Fig. 123); (1) with one apical and one subapical tooth near apex (Fig. 101); (2) with one apical and one subapical tooth distant from apex (Fig. 103); (3) with 3 teeth (Fig. 139); (4) with 2 teeth and one small lobe between them (Fig. 120); (5) with one bilobate subapical tooth (Fig. 149).

22. Penicillus (CI 0.50, RI 0.50): (0) long (Fig. 101); (1) reduced (Fig. 137).

23. Tooth at base of left penicillus (CI 1.00, RI 1.00): (0) present (Figs. 116, 117); (1) absent (Fig. 105).

24. Shape of galea (CI 0.83, RI 0.75): (0) brush-like (Fig. 160); (1) brush-like wide (Fig. 162); (2) transverse (Fig. 163); (3) bilobed (Fig. 166); (4) narrow (tongue-like) (Fig. 169); (5) butterfly wing-like (Fig. 175).

25. Setae of galea (CI 0.37, RI 0.52): (0) simple (Fig. 161); (1) spatulate (Fig. 160); (2) short bristle (Fig. 164); (3) long and bristle (Fig. 167); (4) simple and spatulate (Fig. 163); (5) spiniform and spatulate; (6) thick and spatulate.

26. Lacinia (CI 1.00, RI 1.00): (0) striated (Fig. 167); (1) smooth (Fig. 160).

27. Last palpomere (CI 0.25, RI 0.47): (0) securiform (Fig. 160); (1) slightly widened apicad (Fig. 161); (2) ellipticall (Fig. 165); (3) cylindrical (Fig. 174).

28. Pronotum (CI 0.25, RI 0.33): (0) wider than long (Fig. 204); (1) longer than wide (Fig. 216); (2) as long as wide (Fig. 234).

29. Hind angles of pronotum (CI 0.22, RI 0.22): (0) backwardly directed or slightly divergent (Fig. 204); (1) divergent (Fig. 206); (2) apex inwards (Fig. 217).

30. Hind angles of pronotum (CI 1.00, RI 1.00): (0) with posterolateral appendix (Fig. 230); (1) without posterolateral appendix (Fig. 204).

31. Carina of hind angles of pronotum (CI 0.28, RI 0.16): (0) present (Fig. 204); (1) absent (Fig. 208); (2) weak.

32. Number of carina of hind angles of pronotum (CI 1.00, RI 1.00): (0) one carina present (Fig. 204); (1) 2 carinae present (Fig. 210).

33. Prosternal channel (CI 0.14, RI 0.57): (0) absent; (1) present.

34. Prosternal spine (CI 0.30, RI 0.44): (0) with bilobed apex (Fig. 190); (1) with rounded apex (Fig. 194); (2) with subapical lobe (Fig. 189); (3) with apex widened with tooth (Fig. 191); (4) with subapical prominent lobe (noselike) (Fig. 187); (5) with sharpened apex (Fig. 195); (6) with subapical tooth .

35. Borders of mesosternal cavity (CI 0.50, RI 0.55): (0) declivous; (1) horizontal; (2) horizontal folllowed by declivous; (3) raised and declivous (Fig. 186); (4) slightly declivous followed by strongly declivous.

36. Lateral margin of metacoxal plate (CI 0.50, RI 0.00): (0) strongly narrowed (Fig. 252); (1) slightly narrowed (Fig. 255); (2) widened laterally (Fig. 266).

37. Free margin of metacoxal plate (CI 0.25, RI 0.53): (0) straight (Fig. 270); (1) with small lobe (Fig. 263); (2) with very developed lobe (Fig. 252); (3) with very developed tooth (Fig. 253); (4) with small tooth (Fig. 262); (5) with huge lobe (Fig. 259).

38. Femur (CI 1.00, RI 1.00): (0) normal; (1) widened; (2) very widened.

39. Tibial spurs (IC 0.50, IR 0.50): (0) present; (1) absent.

40. Tibial spurs (CI 0.16, RI 0.56): (0) short; (1) long; (2) very long.

41. Tarsomere 1 (CI 1.00, RI 1.00): (0) normal; (1) very long.

42. Lamella of protarsomere 1 (CI 0.33, RI 0.91): (0) present; (1) absent.

43. Lamella of mesotarsomere 1 (CI 0.33, RI 0.91): (0) present; (1) absent.

44. Lamella of metatarsomere 1 (CI 0.33, RI 0.92): (0) present; (1) absent.

45. Lamella of protarsomere 2 (CI 1.00, RI 1.00): (0) present; (1) absent.

46. Lamella of mesotarsomere 2(CI 1.00, RI 1.00): (0) present; (1) absent.

47. Lamella of metatarsomere 2(CI 1.00, RI 1.00): (0) present; (1) absent.

48. Lamella of protarsomere 3 (CI 1.00, RI 1.00): (0) present; (1) absent.

49. Lamella mesotarsomere 3 (CI 1.00, RI 1.00): (0) present; (1) absent.

50. Lamella of metatarsomere 3 (CI 1.00, RI 1.00): (0) present; (1) absent.

51. Lamella of protarsomere 4 (CI 1.00, RI 1.00): (0) present; (1) absent.

52. Lamella of mesotarsomere 4 (CI 1.00, RI 1.00): (0) present; (1) absent.

53. Lamella of metatarsomere 4 (CI 1.00, RI 1.00): (0) present; (1) absent.

54. Claws (CI 1.00, RI 1.00): (0) without teeth; (1) pectinate.

55. Basal setae of claws (CI 1.00, RI 1.00): (0) present; (1) absent.

56. Shape of sternite 8 of male (CI 0.12, RI 0.50): (0) transversal band (Fig. 273); (1) gradually narrowed to apex (Fig. 283).

57. Anterior margin of sternite 8 of male (CI 0.36, RI 0.44): (0) straight (Fig. 273); (1) narrowed and straight (Fig. 285); (2) straight with prominent angles (Fig. 274); (3) notched at middle (Fig. 283); (4) narrowed and notched at middle (Fig. 281); (5) prominent at middle (Fig. 277); (6) contricted and notched at middle (Fig. 279); (7) slightly notched at middle (Fig. 286); (8) rounded (Fig. 293).

58. Distal margin of tergite 9 of male (CI 0.40, RI 0.55): (0) 
V-shaped (Fig. 332); (1) strongly notched at middle (Fig. 331); (2) moderately notched at middle (Fig. 337); (3) widely notched at middle (Fig. 335); (4) slightly notched at middle (Fig. 344); (5) rounded (Fig. 340); (6) narrowed notched (Fig. 342).

59. Median region of tergite 9 of male (CI 0.33, RI 0.60): (0) wider than a half of tergite (Fig. 331); (1) very narrow (Fig. 339).

60. Apex of sternite 9 of male (CI 0.42, RI 0.55): (0) gradually narrowed (Fig.319); (1) abruptly narrowed (Fig. 322); (2) slightly narrowed (Fig. 330); (3) triangular (Fig. 320).

61. Aedeagus (CI 0.16, RI 0.23): (0) short and wide (Fig. (Fig. 375); (1) elongate (Fig. 379); (2) narrow and long (Fig. 376).

62. Basal piece (CI 0.33, RI 0.50): (0) short and wide (Fig. 383); (1) shorter than parameres (Fig. 375); (2) longer than parameres (Fig. 376); (3) twice parameres length (Fig. 396).

63. Parameres (CI 0.33, RI 0.50): (0) separated (Fig. 401); (1) fused (Fig. 397).

64. Distal region of parameres (CI 1.00, RI 1.00): (0) with setae (Fig. 396); (1) without setae (Fig. 400).

65. Subapical region of parameres (IC 0.53, IR 0.50): (0) securiform (Fig. 375); (1) slitted (Fig. 394); (2) dilated (boot-like) (Fig. 400); (3) narrowed and rounded (Fig. 441); (4) narrowed and truncate (Fig. 466); (5) slightly securiform (Fig. 397); (6) securiform and slitted (Fig. 405); (7) securiform with tooth (Fig. 407).

66. Median lobe (CI 0.25, RI 0.52): (0) slightly longer than parameres (Fig. 374); (1) moderately longer than parameres (Fig. 378); (2) strongly longer than parameres (Fig. 414); (3) twice parameres length (Fig. 402); (4) 1/ 3 longer than parameres (Fig. 422).

67. Lateral margins of median lobe (CI 0.46, RI 0.61): (0) almost straight (Fig. 376); (1) strongly constrict at middle (Fig. 392); (2) gradually narrowed to apex (Fig. 386); (3) strongly narrowed at distal half (Fig. 442); (4) slightly narrowed at distal half (Fig. 406); (5) sinuous (Fig. 412); (6) slightly narrowed at middle (Fig. 422); (7) wider at base (Fig. 449).

68. Apex of median lobe (CI 0.20, RI 0.52): (0) narrowed (Fig. 376); (1) rounded (Fig. 374); (2) widely rounded (Fig. 422).

69. Apex of sternite 8 of female (CI 0.50, RI 0.62): (0) prominent and rounded (Fig. 467); (1) truncate (Fig. 485); (2) widely rounded (Fig. 470); (3) notched at middle (Fig. 473).

70. Length of spiculum gastrale $X$ length of sternite 8 of female (CI 0.33, RI 0.46): (0) below 3 times (Fig. 473); (1) 3.0-3.9 times (Fig. 476); (2) 4.0-4.9 times (Fig. 472); (3) 5.0-5.9 times (Fig. 469); (4) above 6 times (Fig. 485).

71. Ovipositor (CI 1.00, RI 1.00): (0) with styli; (1) without styli.

72. Bursa copulatrix (CI 0.25, RI 0.62): (0) without spines; (1) with spines (Fig. 496).
73. Spines of bursa copulatrix (CI 0.75, RI 0.50): ( 0 ) forming regular areas (Fig. 503); (1) disposed in irregular way (Fig. 502); (2) covering bursa partially (Fig. 508); (3) disposed in spiral or tubular (Fig. 495).

74. Number of spiny areas of bursa copulatrix (CI 0.66, RI 0.66): (0) 3 areas (Fig. 503); (1) 4 areas (Fig. 504); (2) 5 areas (Fig. 501); (3) 6 areas (Figs. 497, 498); (4) 7 areas (Fig. 507).

75. Spiny areas of bursa copulatrix (CI 1.00, RI 1.00): (0) making star-like (Fig. 496); (1) disposed in narrow very long band (Fig. 495); (2) disposed in band and circles (Fig. 503).

76. Bursa copulatrix (CI 0.66, RI 0.50): (0) rounded (Fig. 503); (1) elongate (Fig. 508); (2) elongate and spiraled (Fig. 495) .

77. Openings of colleterial glands (CI 1.00, RI 1.00): (0) without sclerotized structures; (1) with pieces sclerotized (Fig. 511); (2) with rings sclerotized (Fig. 503) .

\section{Matrix}

Table I. Data matrix for Dicrepidiina. (?) missing data; (-) inapplicable characters.

\section{RESULTS}

The first analysis, using equally weighted characters produced 11 equally most-parsimonious trees. The strict consensus tree (L 694, CI 28, RI 37) is showed in Fig. 1.

The second analysis was conducted after aplication of the sucessive weighting option according to the maximum value of the fitness. Using fit 5 resulted in four trees and fits from 10-50 produced one tree with different topology of the anterior ones. For the discussions and conclusions it was used the tree representing the common clades from these five trees (Fig.2).

The trees represented by Figs. 1 and 2 demonstrate that the genus Ovipalpus, represented by type-species, $O$. pubescens, does not belong to Dicrepidiina and even to Ampedini. It is removed from the subtribe and appears to be closely related to Prosternini (Prosterninae).

The subtribe Dicrepidiina (excluding Ovipalpus) (Fig. 2) is a monophyletic group and Physorhinina is the sister group. The subtribe is defined especially by tarsomeres 2 and 3 lamellate in all legs. This result agrees with the characterization commonly used to the subtribe, tarsomeres 2 and 3 lamellate. The tarsomere 3 lamellate (characters $48,49,50$ ) usually used to characterize the Physorhinina, represents here the synapomorphies that define the monophyletic group formed by Physorhinina and Dicrepidiina.

The genera Achrestus, Anoplischius, Dipropus and Propsephus demonstrated not to be monophyletics. In this work, the number of analysed species of each one is insufficient to establish new genera.

The subtribe, as defined here, is composed by: Achrestus, Adiaphorus, Anoplischiopsis, Anoplischius, Atractosomus, Blauta, Calopsephus, Catalamprus, Crepidius, Cyathodera, Dayakus, Dicrepidius, Dipropus, Elius, Heterocrepidius, 
Table I. Data matrix for Dicrepidiina. (?) missing data; (-) inapplicable characters.

\begin{tabular}{llllllllllllllllllllllllllllllllll}
\hline Characters & 0 & 1 & 2 & 3 & 4 & 5 & 6 & 7 & 8 & 9 & 10 & 11 & 12 & 13 & 14 & 15 & 16 & 17 & 18 & 19 & 20 & 21 & 22 & 23 & 24 & 25
\end{tabular}

Chalcolepidius zonatus

Ctenicera silvatica

Melanotus spernendus

Anchastus digittatus

Physorhinus xanthoceplalus

Ampedus sanguineus

Achrestus flavocinctus

Achrestus venustus

Adiaphorus gracilis

Adiaphorus ponticerianus

Anoplischiopsis bivittatus

Anoplischius bicarinatus

Anoplischius conicus

Anoplischius haematopus

Anoplischius pyronotus

Atractosomus flavescens

Blauta cribraria

Calopsephus apicalis

Catalamprus angustus

Crepidius flabellifer

Crepidius resectus

Cyathodera auripilosus

Cyathodera lanugicollis

Cyathodera longicornis

Dayakus angularis

Dicrepidius ramicornis

Dipropus brasilianus

Dipropus factuellus

Dipropus laticollis

Dipropus pinguis

Dipropus schwarzi

Elius birmanicus

Elius dilatatus

Heterocrepidius gilvellus

Heterocrepidius ventralis

Lampropsephus cyaneus

Loboederus appendiculatus

Olophoeus gibbus

Ovipalpus pubescens

Pantolamprus ligneus

Pantolamprus mirabilis

Pantolamprus perpulcher

Paraloboderus glaber

Proloboderus crassipes

Propsephus beniensis

Propsephus cavifrons

Pseudolophoeus guineensis

Rhinopsephus apicalis

Sephilus formosanus

Sephilus frontalis

Singhalenus gibbus

Singhalenus taprobanicus

Sphenomerus antennalis

Sphenomerus brunneus

Spilus atractomorphus

Spilus nitidus

Stenocrepidius simoni

Trielasmus varians $\begin{array}{llllllllllllllllllllllllll}0 & 1 & 0 & 0 & 1 & 1 & - & - & 1 & 1 & 1 & 1 & 0 & 1 & 1 & 3 & 1 & 1 & 3 & 4 & 0 & 0 & 0 & 1 & 0 & 0\end{array}$

$\begin{array}{lllllllllllllllllllllllllllll}0 & 1 & 0 & 0 & 1 & 1 & - & - & 2 & 2 & 1 & 0 & 0 & 5 & 2 & 0 & 1 & 1 & 0 & 0 & 0 & 4 & 0 & 1 & 0 & 0\end{array}$

$\begin{array}{lllllllllllllllllllllllllll}0 & 0 & 1 & 1 & 0 & 0 & 1 & 0 & 2 & 2 & 1 & 0 & 0 & 0 & 1 & 0 & 1 & 1 & 1 & 0 & 1 & 1 & 0 & 1 & 0 & 3\end{array}$

$\begin{array}{llllllllllllllllllllllllllllll}0 & 0 & 1 & 1 & 0 & 0 & 1 & 0 & ? & 2 & 1 & 0 & 0 & ? & 1 & ? & 1 & 1 & 4 & 0 & 0 & 1 & 0 & 1 & 0 & 1\end{array}$

$\begin{array}{lllllllllllllllllllllllllllllll}0 & 0 & 1 & 1 & 0 & 0 & 1 & 0 & 2 & 2 & 1 & 0 & 0 & 4 & 1 & 0 & 0 & 1 & 1 & 0 & 0 & 1 & 0 & 1 & 0 & 1\end{array}$

$\begin{array}{llllllllllllllllllllllllllll}0 & 0 & 1 & 1 & 0 & 0 & 1 & 0 & 2 & 2 & 1 & 0 & 0 & 0 & 1 & 3 & 1 & 1 & 0 & 1 & 0 & 1 & 0 & 1 & 0 & 1\end{array}$

$\begin{array}{llllllllllllllllllllllllll}0 & 0 & 1 & 2 & 0 & 0 & 1 & 0 & 1 & 1 & 1 & 0 & 0 & 1 & 1 & 0 & 1 & 1 & 0 & 0 & 0 & 1 & 0 & 1 & 0 & 1\end{array}$

$\begin{array}{lllllllllllllllllllllllllllllllll}0 & 0 & 1 & 2 & 0 & 0 & 1 & 1 & 3 & 4 & 1 & 0 & 0 & 6 & 2 & 1 & 1 & 1 & 3 & 0 & 0 & 1 & 0 & 1 & 0 & 1\end{array}$

$\begin{array}{lllllllllllllllllllllllllllllllll}0 & 0 & 1 & 1 & 0 & 0 & 1 & 0 & 0 & 1 & 0 & 0 & 0 & 0 & 1 & 2 & 1 & 1 & 0 & 0 & 1 & 2 & 0 & 1 & 0 & 5\end{array}$

$\begin{array}{llllllllllllllllllllllllllllllllll}0 & 0 & 1 & 1 & 0 & 0 & 1 & 0 & 0 & 1 & 0 & 0 & 0 & 0 & 1 & 2 & 1 & 1 & 1 & 1 & 1 & 2 & 0 & 1 & 0 & 0\end{array}$

$\begin{array}{lllllllllllllllllllllllllllllllll}0 & 0 & 1 & 1 & 0 & 0 & 1 & 1 & 1 & 1 & 1 & 0 & 0 & 0 & 1 & 0 & 1 & 1 & 0 & ? & ? & 0 & ? & ? & \text { ? } & \text { ? }\end{array}$

$\begin{array}{llllllllllllllllllllllllll}0 & 2 & 2 & 0 & 1 & 0 & 1 & 0 & 1 & 1 & 1 & 0 & 0 & 1 & 1 & 1 & 1 & 1 & 0 & 1 & 1 & 2 & 0 & 1 & 0 & 1\end{array}$

$\begin{array}{lllllllllllllllllllllllllllllllll}1 & 0 & 1 & 1 & 1 & 0 & 1 & 0 & 1 & 1 & 1 & 0 & 0 & 1 & 2 & 2 & 1 & 1 & ? & ? & ? & ? & ? & ? & ? & \text { ? }\end{array}$

$\begin{array}{llllllllllllllllllllllllll}2 & 2 & 0 & 0 & 1 & 0 & 1 & 0 & 2 & 2 & 1 & 0 & 0 & 1 & 1 & 1 & 1 & 1 & 1 & 1 & 0 & 2 & 0 & 1 & 0 & 1\end{array}$

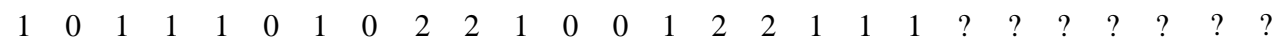

$\begin{array}{llllllllllllllllllllllllll}0 & 2 & 3 & 0 & 0 & 0 & 1 & 0 & 1 & 1 & 1 & 0 & 0 & 1 & 1 & 0 & 1 & 1 & 0 & 1 & 0 & 1 & 0 & 1 & 0 & 0\end{array}$

$\begin{array}{llllllllllllllllllllllllllllll}1 & 0 & 1 & 1 & 0 & 0 & 1 & 0 & 1 & 1 & 1 & 0 & 0 & 3 & 1 & 0 & 1 & 1 & 3 & 4 & 0 & 2 & 0 & 1 & 0 & 0\end{array}$

$\begin{array}{llllllllllllllllllllllllll}2 & 0 & 1 & 2 & 0 & 0 & 1 & 0 & 1 & 2 & 1 & 0 & 0 & 1 & 1 & 1 & 0 & 1 & 1 & 0 & 0 & 1 & 0 & 1 & 1 & 1\end{array}$

$\begin{array}{llllllllllllllllllllllllllllllll}0 & 0 & 1 & 2 & 0 & 0 & 1 & 0 & ? & 1 & 1 & 0 & 0 & 1 & 2 & ? & 0 & 1 & 0 & 0 & 0 & 1 & 0 & 1 & 2 & 4\end{array}$

$\begin{array}{llllllllllllllllllllllllll}1 & 0 & 1 & 2 & 1 & 0 & 1 & 1 & 3 & 1 & 1 & 0 & 0 & 6 & 1 & 1 & 1 & 1 & 3 & 4 & 0 & 1 & 0 & 0 & 0 & 1\end{array}$

$\begin{array}{llllllllllllllllllllllllllllll}1 & 0 & 1 & 2 & 1 & 0 & 1 & 1 & 3 & 1 & 1 & 0 & 0 & 6 & 1 & 1 & 1 & 1 & 0 & 0 & 0 & 1 & 0 & 0 & 0 & 1\end{array}$

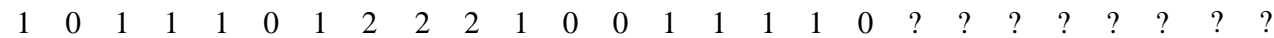

$\begin{array}{llllllllllllllllllllllllllllllllll}1 & 0 & 2 & 1 & 2 & 0 & 1 & 2 & 2 & 2 & 1 & 0 & 0 & 1 & 1 & 1 & 1 & 0 & 2 & 3 & 1 & 2 & 0 & 1 & 0 & 0\end{array}$

$\begin{array}{llllllllllllllllllllllllll}1 & 0 & 2 & 1 & 2 & 0 & 1 & 2 & 2 & 2 & 1 & 0 & 0 & 1 & 2 & 1 & 1 & 0 & 0 & 1 & 1 & 2 & 0 & 1 & 0 & 0\end{array}$

$\begin{array}{lllllllllllllllllllllllllll}0 & 0 & 1 & 1 & 1 & 0 & 1 & 0 & 1 & ? & 1 & 0 & 0 & 1 & 1 & 1 & 1 & 1 & 0 & 0 & 0 & 0 & 0 & 1 & 0 & 2\end{array}$

$\begin{array}{llllllllllllllllllllllllll}1 & 0 & 2 & 0 & 1 & 0 & 0 & 1 & 3 & 1 & 1 & 0 & 0 & 6 & 1 & 1 & 1 & 1 & 5 & 0 & 0 & 1 & 0 & 0 & 0 & 1\end{array}$

$\begin{array}{llllllllllllllllllllllllllll}1 & 0 & 3 & 2 & 1 & 0 & 1 & 0 & 1 & ? & 1 & 0 & 0 & 1 & 1 & 1 & 1 & 1 & 3 & 0 & 0 & 1 & 0 & 1 & 0 & 6\end{array}$

$\begin{array}{llllllllllllllllllllllllll}1 & 0 & 1 & 2 & 1 & 0 & 1 & 0 & 1 & 1 & 1 & 0 & 0 & 1 & 1 & 1 & 1 & 1 & 3 & 0 & 0 & 1 & 0 & 1 & 0 & 1\end{array}$

$\begin{array}{lllllllllllllllllllllllllllll}1 & 0 & 1 & 1 & 0 & 0 & 1 & 0 & 2 & 2 & 1 & 0 & 0 & 1 & 1 & 1 & 1 & 1 & 0 & 0 & 0 & 1 & 0 & 1 & 0 & 1\end{array}$

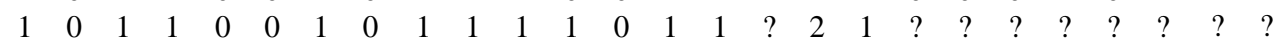

$\begin{array}{lllllllllllllllllllllllllll}1 & 0 & 3 & 1 & 0 & 0 & 1 & 0 & 1 & ? & 1 & 0 & 0 & 1 & 2 & 1 & 1 & 1 & 0 & 0 & 0 & 1 & 0 & 1 & 0 & 1\end{array}$

$\begin{array}{llllllllllllllllllllllllll}1 & 0 & 3 & 2 & 0 & 0 & 1 & 0 & 5 & ? & 1 & 0 & 0 & 7 & 1 & 1 & 1 & 1 & 1 & 0 & 1 & 2 & 0 & 1 & 0 & 0\end{array}$

$\begin{array}{lllllllllllllllllllllllllllll}1 & 0 & 1 & 2 & 0 & 0 & 1 & 0 & 1 & 1 & 1 & 0 & 0 & 1 & 1 & 0 & 1 & 1 & 5 & 1 & 1 & 2 & 0 & 1 & 0 & 0\end{array}$

$\begin{array}{lllllllllllllllllllllllllllllllll}1 & 0 & 1 & 1 & 1 & 0 & 1 & 0 & 2 & ? & 1 & 0 & 0 & 3 & 1 & 0 & 1 & 1 & 5 & 0 & 1 & 2 & 0 & 1 & 0 & 0\end{array}$

$\begin{array}{llllllllllllllllllllllllllllllll}1 & 0 & 1 & 1 & 1 & 0 & 1 & 0 & 2 & ? & 1 & 0 & 0 & 0 & 1 & 0 & 1 & 1 & 0 & 0 & 1 & 2 & 0 & 1 & 0 & 0\end{array}$

$\begin{array}{llllllllllllllllllllllllllllllll}0 & 0 & 1 & 1 & 0 & 0 & 1 & 0 & 4 & 3 & 1 & 0 & 0 & 1 & 1 & 3 & 1 & 1 & 1 & 0 & 0 & 1 & 0 & 1 & 3 & 4\end{array}$

$\begin{array}{llllllllllllllllllllllllllllllllll}0 & 0 & 4 & 2 & 3 & 0 & 1 & 2 & 2 & 2 & 1 & 0 & 0 & 1 & 2 & 1 & 1 & ? & 1 & 0 & 1 & 1 & 1 & 1 & 0 & 0\end{array}$

$\begin{array}{llllllllllllllllllllllllllllllll}2 & 0 & 1 & 0 & 0 & 0 & 1 & 0 & 5 & ? & 1 & 0 & 0 & 1 & 0 & 0 & 1 & 1 & 3 & 0 & 2 & 2 & 1 & 1 & 0 & 0\end{array}$

$\begin{array}{llllllllllllllllllllllllllllll}0 & 1 & 3 & 3 & 4 & 1 & - & - & 1 & ? & 1 & 0 & 0 & 3 & 1 & 0 & 1 & 1 & 2 & 0 & 1 & 3 & 0 & 1 & 4 & 0\end{array}$

$\begin{array}{lllllllllllllllllllllllllllllll}0 & 0 & 1 & 1 & 0 & 0 & 1 & 0 & 6 & ? & 1 & 0 & 0 & 1 & 1 & 0 & 1 & 1 & 1 & 0 & 0 & 1 & 0 & 1 & 3 & 4\end{array}$

$\begin{array}{llllllllllllllllllllllllllllllll}0 & 0 & 1 & 1 & 0 & 0 & 1 & 0 & ? & 5 & 1 & 0 & 0 & 1 & 1 & ? & 1 & 1 & 1 & 0 & 0 & 1 & 0 & 1 & 3 & 4\end{array}$

$\begin{array}{llllllllllllllllllllllllllllllll}0 & 0 & 1 & 1 & 0 & 0 & 1 & 0 & 1 & ? & 1 & 0 & 0 & 1 & 1 & 3 & 1 & 1 & 1 & 0 & 0 & 1 & 0 & ? & 3 & 4\end{array}$

$\begin{array}{llllllllllllllllllllllllllllllll}0 & 0 & 4 & 2 & 3 & 0 & 1 & 0 & 1 & 1 & 1 & 0 & 0 & 1 & 0 & 1 & 1 & 1 & 1 & 0 & ? & ? & ? & ? & ? & ?\end{array}$

$\begin{array}{llllllllllllllllllllllllll}0 & 0 & 4 & 2 & 3 & 0 & 1 & 0 & 4 & 3 & 1 & 0 & 1 & 2 & 1 & 1 & 1 & 1 & 1 & 0 & 1 & 2 & 0 & 1 & 0 & 0\end{array}$

$\begin{array}{llllllllllllllllllllllllllllllll}1 & 0 & 3 & 2 & 1 & 0 & 1 & 1 & 2 & ? & 1 & 0 & 0 & 1 & 1 & 0 & 1 & 1 & 5 & 0 & 0 & 1 & 0 & 1 & 0 & 0\end{array}$

$\begin{array}{llllllllllllllllllllllllllllllll}1 & 0 & 3 & 2 & ? & 0 & 1 & 1 & ? & 1 & 1 & 0 & 0 & 1 & 1 & ? & 1 & 1 & 0 & 0 & 0 & 1 & 0 & 1 & 0 & 0\end{array}$

$\begin{array}{lllllllllllllllllllllllllllll}0 & 0 & 1 & 0 & 4 & 0 & 1 & 0 & 1 & 1 & 1 & 0 & 0 & 1 & 1 & 1 & 0 & 1 & 0 & 1 & 1 & 5 & 1 & 1 & 0 & 2\end{array}$

$\begin{array}{lllllllllllllllllllllllllll}1 & 0 & 1 & 2 & 0 & 0 & 0 & 1 & 1 & 4 & 1 & 0 & 0 & 1 & 1 & 1 & 0 & 1 & 0 & 0 & 0 & 1 & 0 & 1 & 0 & 6\end{array}$

$\begin{array}{llllllllllllllllllllllllllllllll}2 & 0 & 0 & 2 & 0 & 0 & 1 & 1 & 1 & ? & 1 & 0 & 0 & 1 & 1 & 0 & 1 & 1 & 5 & 0 & 0 & 1 & 0 & 1 & 0 & 0\end{array}$

$\begin{array}{llllllllllllllllllllllllllllllllllll}1 & 0 & 0 & 2 & 0 & 0 & 1 & 1 & 5 & 1 & 1 & 1 & 0 & 7 & 2 & 0 & 1 & 1 & 0 & 2 & 0 & 1 & 0 & 1 & 0 & 0\end{array}$

$\begin{array}{llllllllllllllllllllllllll}1 & 0 & 3 & 1 & 0 & 0 & 1 & 0 & 2 & 2 & 1 & 0 & 0 & 1 & 1 & 0 & 1 & 1 & 0 & 1 & 1 & 2 & 0 & 1 & 0 & 0\end{array}$

$\begin{array}{llllllllllllllllllllllllll}1 & 0 & 3 & 1 & 0 & 0 & 1 & 0 & 2 & 2 & 1 & 0 & 0 & 1 & 1 & ? & 1 & 1 & 0 & 1 & 1 & 2 & 0 & 1 & 0 & 0\end{array}$

$\begin{array}{lllllllllllllllllllllllllll}1 & 0 & 3 & 1 & 1 & 0 & 1 & 0 & 5 & 1 & 1 & 0 & 0 & 1 & 1 & 0 & 1 & 1 & 5 & 0 & 1 & 2 & 0 & 1 & 5 & 4\end{array}$

$\begin{array}{lllllllllllllllllllllllllllllllll}1 & 0 & 2 & 0 & 0 & 0 & 1 & 0 & 1 & ? & 1 & 0 & 0 & 1 & 0 & 3 & 1 & 1 & 5 & 0 & 1 & 2 & 0 & 1 & 5 & 4\end{array}$

$\begin{array}{lllllllllllllllllllllllllll}2 & 0 & 1 & 4 & 1 & 0 & 1 & 3 & 1 & 1 & 1 & 0 & 0 & 1 & 1 & 0 & 1 & 1 & 1 & 0 & 0 & 1 & 0 & 1 & 0 & 0\end{array}$

$\begin{array}{llllllllllllllllllllllllllllllll}2 & 0 & 1 & 4 & 1 & 0 & 1 & 3 & 1 & 1 & 1 & 0 & 0 & 1 & 1 & 3 & 1 & 1 & 5 & 0 & 0 & 1 & 0 & 1 & 0 & 0\end{array}$

$\begin{array}{lllllllllllllllllllllllllll}2 & 0 & 1 & 0 & 1 & 0 & 1 & 0 & \text { ? } & ? & 1 & 0 & 0 & 3 & 1 & ? & 1 & 1 & 5 & 0 & 1 & 2 & 0 & 1 & 0 & 0\end{array}$

$\begin{array}{llllllllllllllllllllllllllll}0 & 2 & 1 & 0 & 1 & 0 & 1 & 3 & ? & 1 & 1 & 0 & 0 & 1 & 1 & ? & 1 & 1 & 3 & 0 & 1 & 2 & 0 & 1 & 0 & 0\end{array}$ 
Table I. Cont.

\begin{tabular}{|c|c|c|c|c|c|c|c|c|c|c|c|c|c|c|c|c|c|c|c|c|c|c|c|c|c|c|}
\hline Characters & 26 & 27 & 28 & 29 & 30 & 31 & 32 & 33 & 34 & 35 & 36 & 37 & 38 & 39 & 40 & 41 & 42 & 43 & 44 & 45 & 46 & 47 & 48 & 49 & 50 & 5 \\
\hline Chalcolepidius zonatus & 1 & 0 & 1 & 0 & 1 & 1 & - & 1 & 1 & 1 & 0 & 0 & 0 & 1 & - & 0 & 1 & 1 & 1 & 1 & 1 & 1 & 1 & 1 & 1 & t \\
\hline Ctenicera silvatica & 1 & 0 & 1 & 1 & 1 & 0 & 0 & 0 & 2 & 0 & 0 & 0 & 0 & 0 & 1 & 0 & 1 & 1 & 1 & 1 & 1 & 1 & 1 & 1 & 1 & 1 \\
\hline Melanotus spernendus & 0 & 0 & 0 & 0 & 1 & 0 & 0 & 1 & 2 & 0 & 0 & 0 & 0 & 0 & 1 & 0 & 1 & 1 & 1 & 1 & 1 & 1 & 1 & 1 & 1 & 1 \\
\hline Anchastus digittatus & 1 & 0 & 0 & 0 & 1 & 1 & - & 1 & 2 & 0 & 0 & 3 & 0 & 0 & 2 & 1 & 1 & 1 & 1 & 1 & 1 & 1 & 0 & 0 & 0 & 1 \\
\hline Physorhinus xanthoceplalus & 1 & 0 & 0 & 0 & 1 & 0 & 0 & 1 & 2 & 3 & 0 & 3 & 0 & 0 & 2 & 1 & 1 & 1 & 1 & 1 & 1 & 1 & 0 & 0 & 0 & 1 \\
\hline Ampedus sanguineus & 1 & 0 & 0 & 0 & 1 & 0 & 0 & 1 & 2 & 0 & 0 & 2 & 0 & 0 & 2 & 0 & 1 & 1 & 1 & 1 & 1 & 1 & 1 & 1 & 1 & 1 \\
\hline Achrestus flavocinctus & 1 & 0 & 0 & 0 & 1 & 0 & 0 & 0 & $?$ & 3 & 0 & $?$ & 0 & 0 & 0 & 0 & 0 & 0 & 0 & 0 & 0 & 0 & 0 & 0 & 0 & 1 \\
\hline Achrestus venustus & 1 & 0 & 0 & 1 & 1 & 0 & 0 & 0 & 2 & 0 & 0 & 1 & 0 & 0 & 0 & 0 & 0 & 0 & 0 & 0 & 0 & 0 & 0 & 0 & 0 & 1 \\
\hline Adiaphorus gracilis & 1 & 0 & 1 & 1 & 1 & 0 & 0 & 1 & 1 & 0 & 0 & 1 & 0 & 0 & 0 & 0 & 1 & 1 & 1 & 0 & 0 & 0 & 0 & 0 & 0 & 1 \\
\hline Adiaphorus ponticerianus & 1 & 0 & 1 & 1 & 1 & 0 & 0 & 1 & 1 & 0 & 0 & 1 & 0 & 0 & 0 & 0 & 1 & 1 & 1 & 0 & 0 & 0 & 0 & 0 & 0 & 1 \\
\hline Anoplischiopsis bivittatus & 1 & 2 & 0 & 0 & 1 & 2 & 0 & 1 & 2 & 0 & 0 & 1 & 0 & 0 & 1 & 0 & 1 & 1 & 1 & 0 & 0 & 0 & 0 & 0 & 0 & 1 \\
\hline Anoplischius bicarinatus & 1 & 0 & 0 & 0 & 1 & 0 & 1 & 1 & 0 & 0 & 0 & 0 & 0 & 0 & 1 & 0 & 0 & 0 & 0 & 0 & 0 & 0 & 0 & 0 & 0 & 1 \\
\hline Anoplischius conicus & $?$ & 0 & 0 & 0 & 1 & 0 & 0 & 1 & 2 & 0 & 0 & 0 & 0 & 0 & 1 & 0 & 1 & 1 & 1 & 0 & 0 & 0 & 0 & 0 & 0 & 1 \\
\hline Anoplischius haematopus & 1 & 0 & 0 & 0 & 1 & 0 & 0 & 1 & 0 & 0 & 0 & 0 & 0 & 0 & 2 & 0 & 0 & 0 & 0 & 0 & 0 & 0 & 0 & 0 & 0 & 1 \\
\hline Anoplischius pyronotus & 1 & 0 & 0 & 0 & 1 & 0 & 0 & 1 & 0 & 0 & 0 & 3 & 0 & 0 & 1 & 0 & 1 & 1 & 1 & 0 & 0 & 0 & 0 & 0 & 0 & 1 \\
\hline Atractosomus flavescens & 1 & 0 & 0 & 1 & 1 & 1 & - & 1 & 3 & 1 & 0 & 1 & 0 & 0 & 1 & 0 & 0 & 0 & 0 & 0 & 0 & 0 & 0 & 0 & 0 & 1 \\
\hline Blauta cribraria & 1 & 1 & 2 & 0 & 1 & 0 & 0 & 1 & 1 & 0 & 0 & 3 & 0 & 0 & 0 & 0 & 0 & 0 & 0 & 0 & 0 & 0 & 0 & 0 & 0 & 0 \\
\hline Calopsephus apicalis & 1 & 0 & 0 & 0 & 1 & 0 & 0 & 1 & 0 & 0 & 1 & 3 & 0 & 1 & - & 0 & 1 & 1 & 1 & 0 & 0 & 0 & 0 & 0 & 0 & 1 \\
\hline Catalamprus angustus & 1 & 1 & 0 & 0 & 1 & 0 & 0 & 1 & 3 & 2 & 0 & 3 & 0 & 1 & - & 0 & 1 & 1 & 1 & 0 & 0 & 0 & 0 & 0 & 0 & 1 \\
\hline Crepidius flabellifer & 1 & 0 & 0 & 0 & 1 & 0 & 0 & 0 & 2 & 0 & 0 & 3 & 0 & 0 & 0 & 0 & 0 & 0 & 0 & 0 & 0 & 0 & 0 & 0 & 0 & 1 \\
\hline Crepidius resectus & 1 & 0 & 0 & 0 & 1 & 0 & 0 & 0 & 2 & 0 & 0 & 3 & 0 & 0 & 0 & 0 & 0 & 0 & 0 & 0 & 0 & 0 & 0 & 0 & 0 & 1 \\
\hline Cyathodera auripilosus & 1 & 0 & 0 & 0 & 1 & 0 & 0 & 1 & 2 & 0 & 0 & 0 & 0 & 0 & 2 & 0 & 0 & 0 & 0 & 0 & 0 & 0 & 0 & 0 & 0 & 1 \\
\hline Cyathodera lanugicollis & 1 & 1 & 0 & 0 & 1 & 0 & 0 & 1 & 2 & 0 & 0 & 0 & 0 & 0 & 2 & 0 & 0 & 0 & 0 & 0 & 0 & 0 & 0 & 0 & 0 & 1 \\
\hline Cyathodera longicornis & 1 & 1 & 0 & 1 & 1 & 0 & 0 & 1 & 1 & 0 & 0 & 0 & 0 & 0 & 2 & 0 & 0 & 0 & 0 & 0 & 0 & 0 & 0 & 0 & 0 & 1 \\
\hline Dayakus angularis & 1 & 0 & 0 & 0 & 1 & 0 & 0 & 0 & 5 & 3 & 1 & 5 & 0 & 0 & 1 & 0 & 0 & 0 & 0 & 0 & 0 & 0 & 0 & 0 & 0 & 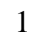 \\
\hline Dicrepidius ramicornis & 1 & 0 & 0 & 1 & 1 & 0 & 0 & 0 & 2 & 2 & 0 & 3 & 0 & 0 & 0 & 0 & 0 & 0 & 0 & 0 & 0 & 0 & 0 & 0 & 0 & 1 \\
\hline Dipropus brasilianus & 1 & 0 & 0 & 0 & 1 & 0 & 0 & 1 & 1 & 0 & 0 & 3 & 0 & 0 & 0 & 0 & 1 & 1 & 1 & 0 & 0 & 0 & 0 & 0 & 0 & 1 \\
\hline Dipropus factuellus & 1 & 0 & 0 & 0 & 1 & 0 & 0 & 1 & 1 & 0 & 0 & 3 & 0 & 0 & 0 & 0 & 1 & 1 & 1 & 0 & 0 & 0 & 0 & 0 & 0 & 1 \\
\hline Dipropus laticollis & 1 & 0 & 0 & 2 & 1 & 0 & 0 & 1 & 2 & 0 & 0 & 0 & 0 & 0 & 1 & 0 & 0 & 0 & 0 & 0 & 0 & 0 & 0 & 0 & 0 & 1 \\
\hline Dipropus pinguis & 1 & 0 & 0 & 0 & 1 & 0 & 0 & 1 & 1 & 0 & 0 & 4 & 0 & 0 & 0 & 0 & 1 & 1 & 1 & 0 & 0 & 0 & 0 & 0 & 0 & 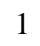 \\
\hline Dipropus schwarzi & 1 & 1 & 0 & 0 & 1 & 0 & 0 & 1 & 2 & 0 & 0 & 4 & 0 & 0 & 1 & 0 & 1 & 1 & 1 & U & 0 & 0 & 0 & 0 & 0 & 1 \\
\hline Elius birmanicus & 1 & 1 & 0 & 0 & 1 & 0 & 0 & 1 & 1 & 0 & 0 & 1 & 0 & 0 & 1 & 0 & 0 & 0 & 1 & 0 & 0 & 0 & 0 & 0 & 0 & 1 \\
\hline Elius dilatatus & 1 & 1 & 0 & 0 & 1 & 0 & 0 & 1 & 1 & 0 & 0 & 1 & 0 & 0 & 1 & 0 & 0 & 0 & 1 & 0 & 0 & 0 & 0 & 0 & 0 & 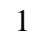 \\
\hline Heterocrepidius gilvellus & 1 & 2 & 0 & 0 & 1 & 2 & 0 & 0 & 2 & 0 & 0 & 2 & 1 & 0 & 1 & 0 & 0 & 0 & 1 & 0 & 0 & 0 & 0 & 0 & 0 & 1 \\
\hline Heterocrepidius ventralis & 1 & 2 & 0 & 0 & 1 & 2 & 0 & 0 & 2 & 0 & 0 & 2 & 1 & 0 & 1 & 0 & 0 & 0 & 1 & 0 & 0 & 0 & 0 & 0 & 0 & 1 \\
\hline Lampropsephus cyaneus & 1 & 0 & 0 & 0 & 1 & 0 & 0 & 1 & 2 & 4 & 0 & 1 & 0 & 0 & 0 & 0 & 1 & 1 & 1 & 0 & 0 & 0 & 0 & 0 & 0 & 1 \\
\hline Loboederus appendiculatus & 1 & 0 & 0 & 0 & 0 & 1 & - & 1 & 1 & 0 & 0 & 1 & 0 & 0 & 1 & 0 & 1 & 1 & 1 & 0 & 0 & 0 & 0 & 0 & 0 & 1 \\
\hline Olophoeus gibbus & 1 & 2 & 0 & 0 & 1 & 0 & 0 & 1 & 2 & 0 & 0 & 0 & 0 & 0 & 1 & 0 & 1 & 1 & 1 & 0 & 0 & 0 & 0 & 0 & 0 & 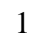 \\
\hline Ovipalpus pubescens & 1 & 2 & 0 & 1 & 1 & 0 & 0 & 0 & 2 & 0 & 2 & 0 & 0 & 0 & 1 & 0 & 1 & 1 & 1 & 1 & 1 & 1 & 1 & 1 & 1 & 1 \\
\hline Pantolamprus ligneus & 1 & 0 & 0 & 0 & 1 & 0 & 0 & 1 & 3 & 3 & 0 & 0 & 0 & 0 & 1 & 0 & 0 & 0 & 0 & 0 & 0 & 0 & 0 & 0 & 0 & 1 \\
\hline Pantolamprus mirabilis & 1 & 0 & 2 & 0 & 1 & 0 & 0 & 1 & 3 & 3 & 0 & 0 & 0 & 0 & 1 & 0 & 0 & 0 & 0 & 0 & 0 & 0 & 0 & 0 & 0 & 1 \\
\hline Pantolamprus perpulcher & 1 & 0 & 2 & 0 & 1 & 0 & 0 & 1 & 3 & 3 & 0 & 0 & 0 & 0 & 1 & 0 & 0 & 0 & 0 & 0 & 0 & 0 & 0 & 0 & 0 & 1 \\
\hline Paraloboderus glaber & $?$ & 1 & 0 & 0 & 1 & 0 & 0 & 0 & 2 & 0 & 0 & 0 & 0 & 0 & 1 & 0 & 0 & 0 & 0 & 0 & 0 & 0 & 0 & 0 & 0 & 1 \\
\hline Proloboderus crassipes & 1 & 1 & 0 & 0 & 1 & 0 & 0 & 0 & 1 & 0 & 0 & 0 & 2 & 0 & 1 & 0 & 1 & 1 & 1 & 0 & 0 & 0 & 0 & 0 & 0 & 1 \\
\hline Propsephus beniensis & 1 & 0 & 0 & 0 & 1 & 0 & 0 & 1 & 2 & 0 & 0 & 4 & 0 & 0 & 1 & 0 & 0 & 0 & 0 & 0 & 0 & 0 & 0 & 0 & 0 & 1 \\
\hline Propsephus cavifrons & 1 & 0 & 0 & 0 & 1 & 0 & 0 & 1 & 2 & 0 & 0 & 4 & 0 & 0 & 1 & 0 & 0 & 0 & 0 & 0 & 0 & 0 & 0 & 0 & 0 & 1 \\
\hline Pseudolophoeus guineensis & 1 & 3 & 0 & 0 & 1 & 0 & 0 & 0 & 2 & 0 & 0 & 4 & 0 & 0 & 2 & 0 & 1 & 1 & 1 & 0 & 0 & 0 & 0 & 0 & 0 & 1 \\
\hline Rhinopsephus apicalis & 1 & 1 & 1 & 0 & 1 & 0 & 0 & 1 & 6 & 0 & 1 & 3 & 0 & 0 & 0 & 0 & 1 & 1 & 1 & 0 & 0 & 0 & 0 & 0 & 0 & 1 \\
\hline Sephilus formosanus & 1 & 0 & 0 & 0 & 1 & 0 & 0 & 1 & 1 & 0 & 0 & 0 & 0 & 0 & 0 & 0 & 0 & 0 & 0 & 0 & 0 & 0 & 0 & 0 & 0 & 1 \\
\hline Sephilus frontalis & 1 & 0 & 0 & 0 & 1 & 0 & 0 & 1 & 1 & 0 & 0 & 0 & 0 & 0 & 0 & 0 & 0 & 0 & 0 & 0 & 0 & 0 & 0 & 0 & 0 & 1 \\
\hline Singhalenus gibbus & 1 & 0 & 1 & 0 & 1 & 0 & 0 & 1 & 1 & 0 & 0 & 4 & 0 & 0 & 0 & 0 & 0 & 0 & 0 & 0 & 0 & 0 & 0 & 0 & 0 & 1 \\
\hline Singhalenus taprobanicus & 1 & 0 & 1 & 0 & 1 & 0 & 0 & 1 & 1 & 0 & 0 & 4 & 0 & 0 & 0 & 0 & 0 & 0 & 0 & 0 & 0 & 0 & 0 & 0 & 0 & 1 \\
\hline Sphenomerus antennalis & 1 & 1 & 1 & 1 & 1 & 1 & - & 1 & 1 & 0 & 0 & 1 & 0 & 0 & 1 & 0 & 0 & 0 & 0 & 0 & 0 & 0 & 0 & 0 & 0 & 1 \\
\hline Sphenomerus brunneus & 1 & 1 & 0 & 0 & 1 & 0 & 0 & 1 & 2 & 0 & 0 & 1 & 0 & 0 & 1 & 0 & 0 & 0 & 0 & 0 & 0 & 0 & 0 & 0 & 0 & 1 \\
\hline Spilus atractomorphus & 1 & 0 & 0 & 0 & 1 & 0 & 0 & 1 & 4 & 3 & 0 & 3 & 0 & 0 & 1 & 0 & 0 & 0 & 0 & 0 & 0 & 0 & 0 & 0 & 0 & 1 \\
\hline Spilus nitidus & 1 & 0 & 0 & 0 & 1 & 0 & 0 & 1 & 4 & 3 & 0 & 3 & 0 & 0 & 1 & 0 & 0 & 0 & 0 & 0 & 0 & 0 & 0 & 0 & 0 & 1 \\
\hline Stenocrepidius simoni & 1 & 2 & 0 & 1 & 1 & 0 & 0 & 0 & 0 & 0 & 0 & 1 & 0 & 0 & 1 & 0 & 1 & 1 & 1 & 0 & 0 & 0 & 0 & 0 & 0 & 1 \\
\hline Trielasmus varians & 1 & 1 & 0 & 0 & 1 & 0 & 0 & 0 & 2 & 0 & 0 & 0 & 0 & 0 & 1 & 0 & 0 & 0 & 0 & 0 & 0 & 0 & 0 & 0 & 0 & 1 \\
\hline
\end{tabular}


Table I. Cont.

Characters

$\begin{array}{llllllllllllllllllllllllll}52 & 53 & 54 & 55 & 56 & 57 & 58 & 59 & 60 & 61 & 62 & 63 & 64 & 65 & 66 & 67 & 68 & 69 & 70 & 71 & 72 & 73 & 74 & 75 & 76 & 77\end{array}$

Chalcolepidius zonatus

Ctenicera silvatica

Melanotus spernendus

Anchastus digittatus

Physorhinus xanthoceplalus

Ampedus sanguineus

Achrestus flavocinctus

Achrestus venustus

Adiaphorus gracilis

Adiaphorus ponticerianus

Anoplischiopsis bivittatus

Anoplischius bicarinatus

Anoplischius conicus

Anoplischius haematopus

Anoplischius pyronotus

Atractosomus flavescens

Blauta cribraria

Calopsephus apicalis

Catalamprus angustus

Crepidius flabellifer

Crepidius resectus

Cyathodera auripilosus

Cyathodera lanugicollis

Cyathodera longicornis

Dayakus angularis

Dicrepidius ramicornis

Dipropus brasilianus

Dipropus factuellus

Dipropus laticollis

Dipropus pinguis

Dipropus schwarzi

Elius birmanicus

Elius dilatatus

Heterocrepidius gilvellus

Heterocrepidius ventralis

Lampropsephus cyaneus

Loboederus appendiculatus

Olophoeus gibbus

Ovipalpus pubescens

Pantolamprus ligneus

Pantolamprus mirabilis

Pantolamprus perpulcher

Paraloboderus glaber

Proloboderus crassipes

Propsephus beniensis

Propsephus cavifrons

Pseudolophoeus guineensis

Rhinopsephus apicalis

Sephilus formosanus

Sephilus frontalis

Singhalenus gibbus

Singhalenus taprobanicus

Sphenomerus antennalis

Sphenomerus brunneus

Spilus atractomorphus

Spilus nitidus

Stenocrepidius simoni

Trielasmus varians $\begin{array}{lllllllllllllllllllllllllllll}1 & 1 & 0 & 0 & 1 & 1 & 5 & 0 & 0 & 1 & 1 & 1 & 0 & 1 & 0 & ? & 1 & 3 & 0 & 1 & 1 & 0 & 0 & 2 & 0 & 2\end{array}$

$\begin{array}{lllllllllllllllllllllllllllllllllll}1 & 1 & 0 & 1 & 0 & 2 & 0 & 0 & 0 & 0 & 0 & 0 & 1 & 2 & 0 & 2 & 0 & 0 & 1 & 0 & 0 & - & - & - & 1 & 0\end{array}$

$\begin{array}{llllllllllllllllllllllllll}1 & 1 & 1 & 1 & 0 & 4 & 1 & 0 & 0 & 0 & 1 & 0 & 0 & 0 & 0 & 2 & 0 & 0 & 0 & 0 & 1 & 2 & - & - & 1 & 0\end{array}$

$\begin{array}{llllllllllllllllllllllllllllll}1 & 1 & 0 & 1 & \text { ? } & \text { ? } & \text { ? } & \text { ? } & \text { ? } & \text { ? } & \text { ? } & \text { ? } & \text { ? } & \text { ? } & \text { ? } & \text { ? } & \text { ? } & 0 & 3 & 0 & 1 & 3 & - & 1 & 2 & 0\end{array}$

$\begin{array}{lllllllllllllllllllllllllllll}1 & 1 & 0 & 1 & 0 & 4 & 0 & 1 & 0 & 0 & 2 & 1 & 0 & 3 & 1 & 3 & 1 & 1 & 4 & 0 & 1 & 3 & - & - & 1 & 1\end{array}$

$\begin{array}{llllllllllllllllllllllllll}1 & 1 & 0 & 1 & 0 & 2 & 1 & 0 & 0 & 0 & 0 & 0 & 0 & 0 & 1 & 0 & 0 & ? & ? & ? & ? & ? & ? & ? & \text { ? }\end{array}$

$\begin{array}{llllllllllllllllllllllllll}1 & 1 & 0 & 1 & 0 & 0 & 1 & 0 & 0 & 0 & 1 & 1 & 0 & 0 & 0 & 0 & 1 & 0 & 0 & 0 & 1 & 0 & 3 & 0 & 0 & 0\end{array}$

$\begin{array}{llllllllllllllllllllllllllllllllll}1 & 1 & 0 & 1 & 0 & 0 & 1 & 0 & 0 & 2 & 2 & 1 & 0 & 0 & 2 & 0 & 0 & 0 & 3 & 0 & 0 & - & - & - & 0 & 0\end{array}$

$\begin{array}{lllllllllllllllllllllllllllllll}1 & 1 & 0 & 1 & 0 & 2 & 0 & 0 & 0 & 1 & 1 & 1 & 0 & 0 & 1 & 2 & 1 & ? & ? & ? & ? & ? & ? & ? & \text { ? }\end{array}$

$\begin{array}{llllllllllllllllllllllllllllllll}1 & 1 & 0 & 1 & 0 & 2 & 0 & 0 & 0 & 1 & 1 & 1 & 0 & 0 & 1 & 2 & 1 & ? & ? & ? & ? & ? & ? & ? & ?\end{array}$

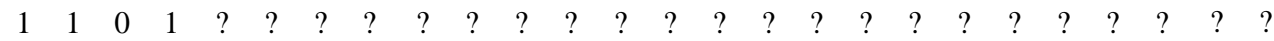

$\begin{array}{llllllllllllllllllllllllllllll}1 & 1 & 0 & 1 & 0 & 0 & 3 & 0 & 0 & 2 & 1 & 1 & 0 & 0 & 1 & 2 & 1 & ? & ? & ? & ? & ? & ? & ? & ? & \text { ? }\end{array}$

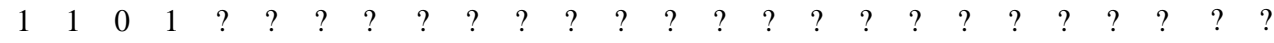

$\begin{array}{llllllllllllllllllllllllll}1 & 1 & 0 & 1 & 0 & 0 & 3 & 0 & 0 & 1 & 1 & 1 & 0 & 0 & 1 & 2 & 1 & ? & ? & ? & ? & ? & ? & ? & ? & ?\end{array}$

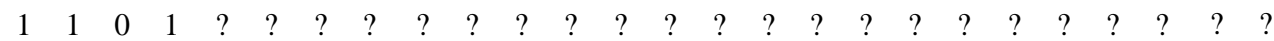

$\begin{array}{llllllllllllllllllllllllll}1 & 1 & 0 & 1 & 0 & 5 & 2 & 0 & 0 & 0 & 1 & 1 & 0 & 0 & 0 & 2 & 0 & 2 & 1 & 0 & 1 & 0 & 3 & 0 & 0 & 0\end{array}$

$\begin{array}{llllllllllllllllllllllllllllllll}0 & 0 & 0 & 1 & 0 & 0 & 1 & 0 & 0 & 1 & 1 & 1 & 0 & 0 & 0 & 2 & 0 & 0 & 1 & 0 & 1 & 0 & 3 & 0 & 0 & 0\end{array}$

$\begin{array}{llllllllllllllllllllllllll}1 & 1 & 0 & 1 & 0 & 6 & 0 & 1 & 0 & 1 & 1 & 1 & 0 & 0 & 1 & 1 & 1 & 0 & 1 & 0 & 1 & 0 & 2 & 0 & 0 & 0\end{array}$

$\begin{array}{llllllllllllllllllllllllllllll}1 & 1 & 0 & 1 & \text { ? } & \text { ? } & \text { ? } & \text { ? } & \text { ? } & \text { ? } & \text { ? } & \text { ? } & \text { ? } & \text { ? } & \text { ? } & \text { ? } & \text { ? } & 0 & 2 & 0 & 1 & 1 & - & - & 0 & 0\end{array}$

$\begin{array}{llllllllllllllllllllllllll}1 & 1 & 0 & 1 & 0 & 4 & 2 & 0 & 3 & 1 & 3 & 1 & 0 & 5 & 1 & 0 & 0 & 2 & 3 & 0 & 1 & 0 & 1 & 0 & 0 & 0\end{array}$

$\begin{array}{llllllllllllllllllllllllllllll}1 & 1 & 0 & 1 & 0 & 4 & 6 & 0 & 0 & 1 & 3 & 1 & 0 & 5 & 1 & 0 & 0 & 2 & 3 & 0 & 1 & 1 & - & - & 0 & 0\end{array}$

$\begin{array}{lllllllllllllllllllllllllllllll}1 & 1 & 0 & 1 & ? & ? & 4 & 0 & 1 & 1 & 2 & 1 & 0 & 0 & 3 & 0 & 0 & ? & ? & ? & ? & ? & ? & ? & \text { ? } & \text { ? }\end{array}$

$\begin{array}{lllllllllllllllllllllllllllllll}1 & 1 & 0 & 1 & 1 & 3 & 4 & 0 & 1 & 1 & 2 & 1 & 0 & 0 & 3 & 0 & 0 & ? & ? & ? & ? & ? & ? & \text { ? } & \text { ? } & \text { ? }\end{array}$

$\begin{array}{llllllllllllllllllllllllll}1 & 1 & 0 & 1 & 1 & 3 & 4 & 0 & 1 & 1 & 2 & 1 & 0 & 6 & 3 & 0 & 0 & 2 & 2 & 0 & 0 & - & - & - & 0 & 0\end{array}$

$\begin{array}{llllllllllllllllllllllllll}1 & 1 & 0 & 1 & 1 & 1 & 5 & 0 & 0 & 0 & 2 & 1 & 0 & 7 & 0 & 4 & 0 & ? & ? & ? & ? & ? & ? & ? & \text { ? } & \text { ? }\end{array}$

$\begin{array}{lllllllllllllllllllllllllllll}1 & 1 & 0 & 1 & 1 & 7 & 4 & 0 & 0 & 1 & 3 & 1 & 0 & 5 & 1 & 4 & 0 & 0 & 3 & 0 & 1 & 0 & 1 & - & 0 & 0\end{array}$

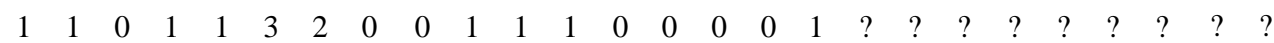

$\begin{array}{llllllllllllllllllllllllll}1 & 1 & 0 & 1 & 1 & 3 & 1 & 0 & 0 & 0 & 2 & 1 & 0 & 5 & 1 & 5 & 0 & 0 & 2 & 0 & 0 & - & - & - & 0 & 0\end{array}$

$\begin{array}{llllllllllllllllllllllllll}1 & 1 & 0 & 1 & 1 & 3 & 4 & 0 & 0 & 2 & 1 & 1 & 0 & 6 & 2 & 0 & 0 & 0 & 2 & 0 & 0 & - & - & - & ? & 0\end{array}$

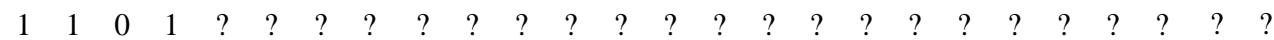

$\begin{array}{lllllllllllllllllllllllllllllll}1 & 1 & 0 & 1 & 1 & 1 & 1 & 0 & 0 & 1 & 1 & 1 & 0 & 7 & 1 & 0 & 0 & ? & ? & ? & ? & ? & ? & ? & ? & \text { ? }\end{array}$

$\begin{array}{llllllllllllllllllllllllll}1 & 1 & 0 & 1 & 1 & 3 & 1 & 0 & 0 & 1 & 1 & 1 & 0 & 7 & 2 & 0 & 0 & ? & ? & ? & ? & ? & ? & ? & ? & ?\end{array}$

$\begin{array}{llllllllllllllllllllllllllllll}1 & 1 & 0 & 1 & 1 & 7 & 2 & 0 & 2 & 1 & 1 & 1 & 0 & 7 & 1 & 0 & 0 & ? & ? & ? & ? & ? & ? & ? & ? & \text { ? }\end{array}$

$\begin{array}{llllllllllllllllllllllllllllllll}1 & 1 & 0 & 1 & 0 & 8 & 1 & 1 & 1 & 1 & 2 & 1 & 0 & 0 & 4 & 6 & 2 & ? & ? & ? & ? & ? & ? & ? & ? & \text { ? }\end{array}$

$\begin{array}{llllllllllllllllllllllllll}1 & 1 & 0 & 1 & 0 & 0 & 1 & 1 & 0 & 1 & 2 & 1 & 0 & 0 & 4 & 0 & 2 & ? & ? & ? & ? & ? & ? & \text { ? } & \text { ? } & \text { ? }\end{array}$

$\begin{array}{llllllllllllllllllllllllll}1 & 1 & 0 & 1 & 0 & 0 & 0 & 1 & 1 & 0 & 1 & 1 & 0 & 0 & 1 & 2 & 1 & 0 & 1 & 0 & 1 & 0 & 4 & 0 & 0 & 0\end{array}$

$\begin{array}{lllllllllllllllllllllllllllllllll}1 & 1 & 0 & 1 & 1 & 3 & 4 & 0 & 1 & 1 & 1 & 0 & 0 & 6 & 2 & 6 & 0 & 0 & 1 & 0 & 0 & - & - & - & 0 & 0\end{array}$

$\begin{array}{lllllllllllllllllllllllllllllll}1 & 1 & 0 & 1 & 0 & 0 & 2 & 0 & 0 & 0 & 1 & 1 & 0 & 0 & 2 & 2 & 1 & ? & ? & ? & ? & ? & ? & \text { ? } & \text { ? } & \text { ? }\end{array}$

$\begin{array}{lllllllllllllllllllllllllllllll}1 & 1 & 0 & 1 & 1 & 4 & 2 & 0 & 0 & 1 & 0 & 0 & 1 & 2 & 0 & 2 & 1 & ? & ? & ? & ? & ? & ? & ? & ? & ?\end{array}$

$\begin{array}{llllllllllllllllllllllllllllllll}1 & 1 & 0 & 1 & ? & ? & ? & ? & ? & 1 & 1 & 1 & 0 & 0 & 0 & 6 & 0 & ? & ? & ? & ? & ? & ? & ? & \text { ? } & \text { ? }\end{array}$

$\begin{array}{llllllllllllllllllllllllll}1 & 1 & 0 & 1 & ? & ? & ? & ? & ? & ? & ? & ? & ? & ? & ? & ? & ? & 0 & 0 & 0 & 1 & 0 & 2 & 0 & 0 & 0\end{array}$

$\begin{array}{llllllllllllllllllllllllllllllll}1 & 1 & 0 & 1 & ? & ? & ? & ? & ? & 1 & 1 & 1 & 0 & 0 & 0 & 6 & 0 & ? & ? & ? & ? & ? & ? & ? & \text { ? } & \text { ? }\end{array}$

$\begin{array}{lllllllllllllllllllllllllllll}1 & 1 & 0 & 1 & ? & ? & ? & ? & ? & 1 & 1 & 1 & 0 & 6 & 2 & 0 & 1 & ? & ? & ? & ? & ? & ? & ? & \text { ? } & \text { ? }\end{array}$

$\begin{array}{llllllllllllllllllllllllll}1 & 1 & 0 & 1 & 1 & 3 & 4 & 0 & 1 & 1 & 1 & 1 & 0 & 6 & 4 & 0 & 0 & 0 & 1 & 0 & 0 & - & - & - & 0 & 0\end{array}$

$\begin{array}{lllllllllllllllllllllllllllllllll}1 & 1 & 0 & 1 & 0 & 0 & 1 & 0 & 0 & 1 & 1 & 1 & 0 & 0 & 0 & 2 & 1 & ? & ? & ? & ? & ? & ? & ? & \text { ? } & \text { ? }\end{array}$

$\begin{array}{lllllllllllllllllllllllllll}1 & 1 & 0 & 1 & \text { ? } & \text { ? } & \text { ? } & \text { ? } & \text { ? } & \text { ? } & \text { ? } & \text { ? } & \text { ? } & \text { ? } & \text { ? } & \text { ? } & ? & 2 & 1 & 0 & 1 & 0 & 3 & 0 & 0 & 0\end{array}$

$\begin{array}{lllllllllllllllllllllllllllllllll}1 & 1 & 0 & 1 & 0 & 0 & 4 & 0 & 0 & 1 & 1 & 1 & 0 & 0 & 0 & 0 & 1 & 0 & 0 & 0 & 0 & - & - & - & 0 & 0\end{array}$

$\begin{array}{lllllllllllllllllllllllllll}1 & 1 & 0 & 1 & 0 & 2 & 0 & 1 & 0 & 1 & 1 & 1 & 0 & 0 & 0 & 7 & 1 & 2 & 2 & 0 & 1 & 0 & 2 & 0 & 0 & 0\end{array}$

$\begin{array}{lllllllllllllllllllllllllllllll}1 & 1 & 0 & 1 & 0 & 0 & 1 & 0 & 0 & 1 & 1 & 1 & 0 & 0 & 1 & 0 & 0 & ? & ? & ? & ? & ? & ? & \text { ? } & \text { ? } & \text { ? }\end{array}$

$\begin{array}{lllllllllllllllllllllllllll}1 & 1 & 0 & 1 & 1 & 3 & 1 & 0 & 0 & 1 & 1 & 1 & 0 & 7 & 1 & 0 & 0 & 0 & 0 & 0 & 1 & 0 & 4 & 0 & 0 & 0\end{array}$

$\begin{array}{lllllllllllllllllllllllllll}1 & 1 & 0 & 1 & 0 & 2 & 1 & 0 & 0 & 1 & 1 & 1 & 0 & 0 & 1 & 2 & 0 & 2 & 1 & 0 & 1 & 0 & 4 & 0 & 0 & 0\end{array}$

$\begin{array}{lllllllllllllllllllllllllll}1 & 1 & 0 & 1 & 0 & 3 & 1 & 0 & 1 & 1 & 1 & 1 & 0 & 0 & 1 & 2 & 0 & 2 & 2 & 0 & 1 & 0 & 4 & 0 & 0 & 0\end{array}$

$\begin{array}{llllllllllllllllllllllllllll}1 & 1 & 0 & 1 & 0 & 2 & 1 & 0 & 2 & 0 & 1 & 1 & 0 & 0 & 2 & 2 & 1 & ? & ? & ? & ? & ? & ? & \text { ? } & \text { ? } & \text { ? }\end{array}$

$\begin{array}{llllllllllllllllllllllllllll}1 & 1 & 0 & 1 & 0 & 2 & 1 & 0 & 2 & 1 & 1 & 1 & 0 & 0 & 2 & 2 & 0 & ? & ? & ? & ? & ? & ? & ? & \text { ? } & \text { ? }\end{array}$

$\begin{array}{lllllllllllllllllllllllllll}1 & 1 & 0 & 1 & \text { ? } & ? & ? & ? & ? & ? & ? & ? & ? & ? & ? & ? & ? & 2 & 1 & 0 & 1 & 0 & 3 & 0 & 0 & 0\end{array}$

$\begin{array}{lllllllllllllllllllllllllllllll}1 & 1 & 0 & 1 & 0 & 8 & 1 & 0 & 0 & 1 & 1 & 1 & 0 & 0 & ? & 2 & ? & ? & ? & ? & ? & ? & ? & ? & \text { ? } & \text { ? }\end{array}$

$\begin{array}{llllllllllllllllllllllllllllll}1 & 1 & 0 & 1 & 0 & 8 & 1 & 0 & 0 & 0 & 1 & 1 & 0 & 4 & 2 & 2 & 0 & ? & ? & ? & ? & ? & ? & ? & ? & \text { ? }\end{array}$

$\begin{array}{lllllllllllllllllllllllllllllll}1 & 1 & 0 & 1 & \text { ? } & \text { ? } & \text { ? } & \text { ? } & \text { ? } & \text { ? } & \text { ? } & \text { ? } & \text { ? } & \text { ? } & \text { ? } & \text { ? } & \text { ? } & 0 & 2 & 0 & 0 & - & - & - & 0 & 0\end{array}$ 
Lampropsephus, Loboederus, Olophoeus, Pantolamprus, Paralobederus, Proloboderus, Propsephus, Pseudolophoeus, Rhinopsephus, Sephilus, Singhalenus, Sphenomerus, Spilus, Stenocrepidius, Trielasmus. The genera Asebis, Lamononia, Neopsephus, Semiotopsis and Spilomorphus were not examined, but based on the original descriptions it was possible to indicate that they belong to Dicrepidiina except Asebis, that probably belongs to Physorhinina.

The tree (Fig. 2) represents the relationships among the Dicrepidiina genera. One monophyletic group is formed by 22 genera, separated in several groups of genera. The relationships of these groups, the majority defined by homoplastic synapomorphies, are not clear. The same occur with the remainder genera. A more consistent and better resolved topology will be possible, including in the analysis more taxa and more characters, not available at moment.

\section{Dicrepidiina Candèze, 1859}

Elatérides vrais (pars) Lacordaire, 1857: 137, 167

Dicrépidiites Candèze, 1859: 3, 5; 1891: 49 (cat.)

Dicrepidiini; Champion, 1894: 292; Schwarz, 1906: 4, 59; Heyne \& Taschenberg., 1908: 155

Dicrepidiina; Blackwelder, 1944: 297 (cat.).

Dicrepidina Hyslop, 1917: 258 (incorrect stem formation)

Dicripidiinae Fleutiaux, 1919: 5 (incorrect stem spelling).

Dicrepidiinae Fleutiaux, 1919: 38; 1922: 407, 428; Schenkling, 1925: 73 (cat.).

Type genus: Dicrepidius Eschscholtz, 1829.

It is characterized by synapomorphies, 45(0) lamella of protarsomere 2 present, 46(0) lamella of mesotarsomere 2 present and 47(0) lamella of metatarsomere 2 present, and by homoplasies, 9(1) antennae of female serrate, 57(0) anterior margin of sternite 8 of male straight and 68(0) apex of median lobe narrowed. Besides, it presents tarsomere 3 lamellate in all legs, character shared with Physorhinina.

\section{Achrestus Candèze, 1869}

Anepsius Candèze, 1859: 155, 156 (preoccupied).

Achrestus Candèze, 1869: 122; Candèze, 1891: 64 (cat.); Champion, 1895: 339; Schwarz, 1906: 83; Schenkling, 1925: 99 (cat.); Blackwelder, 1944: 291 (cat.); Costa \& Casari-Chen, 1990: 304.

Type-species: Anepsius flavocinctus Candèze, 1859, designated by Hyslop, 1921.

Candèze (1859) erected the genus Anepsius to 4 new species and included it in "Eudactylites". The genus was characterized specially by tarsomeres slightly widened, $2^{\text {nd }}$ and $3^{\text {rd }}$ lamellate and $4^{\text {th }}$ small, not dilatate. In 1869 he changed the name Anepsius to Achrestus, because the former was preoccupied with Anepsius LeConte, 1851 (Tenebrionidae).

Fleutiaux (1919) changed the name Eudactylini to Pachyderini.

Schenkling (1925) and Blackwelder (1944) included Achrestus in Pachyderinae.

Costa \& Casari-Chen (1990) transferred Achrestus to

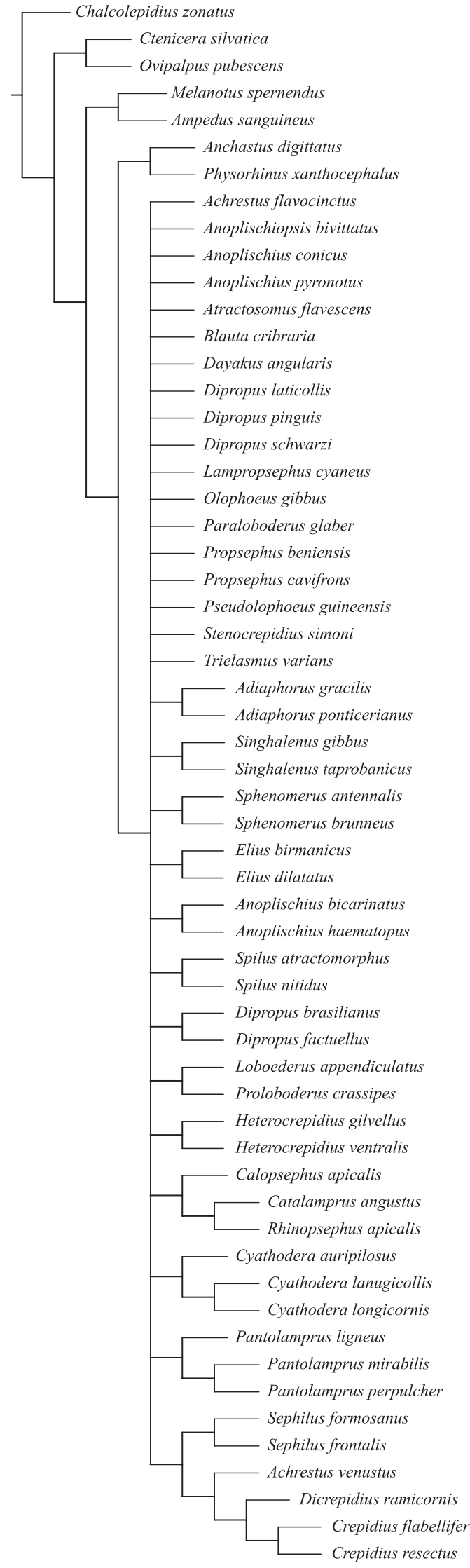

Fig. 1. Consensus tree of 11 equally most parsimonious trees (L 694, CI 28, RI 37). All characters were weighted equally. 
Dicrepidiinae. They studied nine species and presented a generic discussion and the redescription of the type-species, A. flavocinctus (Candèze, 1859). They concluded that the genus is composed by two characteristic groups, separated specially by body and antennal shapes. In $A$. antennalis, $A$. flavocinctus, A. marginatus, A. ruficollis, A. saucius, A. suturalis $\mathrm{e}$ A. trilineatus, the antennae are serrate in both sexes and the elytra laterally parallel giving more robust appearance. In the remainder species, the antennae are flabellate in male and serrate in female and the elytra narrowed apicad, giving a slender appearance.

The genus is composed by 12 species: Achrestus antennalis Schwarz, 1902, A. flavocinctus (Candèze, 1859), A. fulvovittatus Champion, 1895, A. lycidioides (Candèze, 1859), A marginatus (Candèze, 1859), A marginicollis Fleutiaux, 1902, A. phyllocerus (Candèze, 1859), A ruficollis Fleutiaux, 1902, A saucius (Candèze, 1859), A suturalis Schwarz, 1902, A trilineatus Schwarz, 1902 and A venustus Champion, 1895. It is recorded from Central (Nicaragua, Costa Rica) and South America (Colombia, Venezuela, Guyana, French Guiana, Brazil, Peru and Bolivia).

The present cladistic analysis demonstrates that the studied Achrestus species do not form a monophyletic group. This result agrees with Costa \& Casari-Chen (1990) that recognized two groups of species in this genus. A new genus was not established because the number of examined species is not sufficient to do it, considering the size of the genus. Achrestus flavocinctus, the type-species, is the sister-group of Dayakus angularis, and is characterized by homoplasies, 3(2) anterior margin of frons strongly prominent, 40(0) tibial spurs short and 68(1) apex of median lobe rounded. Achrestus venustus is the sister-group of ((Dicrepidius ramicornis)(Crepidius)) and is characterized by homoplasies, $0(0)$ frons wider than long, 9(4) antennae of female pectinate, 14(2) antennomere 3 as long as 4, 61(2) aedeagus narrow and long, 66(2) median lobe strongly longer than parameres and 72 (0) bursa copulatrix with spines.

Achrestus flavocinctus (Candèze, 1859)

(Figs. 3, 54, 101, 186, 187, 204, 273, 312, 331, 374, 375, 467, 496).

Anepsius flavocinctus Candèze, 1859: 157; 1891: 64 (cat.).

Achrestus flavocinctus; Schenkling, 1925: 99 (cat.); Blackwelder, 1944: 291; Costa \& Casari, 1990: 304.

Length: 10.5-14.5 mm. General integument dark-brown and yellow; frons dark-brown with median anterior triangular yellow spot; prothorax yellow with a median large dark-brown spot, narrower on anterior half and two lateromedian spots reaching hypomera; meso-, metathorax, scutellum and elytra dark-brown; elytra with sutural short yellow band behind scutellum; legs clearer than general integument; coxae and trochanters yellow; antennae dark-brown or black. Pubescence moderately dense and long; yellowish on yellow integument and brownish on dark-brown. Frons carinate, wider than long, concave at middle near anterior margin in a triangular area; anterior margin prominent and surpassing nasal; punctuation small and dense. Nasal wider than long. Antennae (Fig. 3) with 11 antennomeres; in male 1.5 antennomere longer than hind angles of pronotum; slightly serrate in both sexes; scape shorter than eye; $2^{\text {nd }}$ antennomere globular, $3^{\text {rd }}$ triangular elongate, shorter than $4^{\text {th }}$, last narrowed at apex. Labrum (Fig. 54) semielliptical with long setae. Mandibles (Fig. 101) robust, with one apical and one subapical tooth; penicillus formed by short setae disposed in whole mesal area; molar area well developed; dorsal region with carina and moderadely long setae. Maxillae: galea with spatulate setae; last palpomere securiform. Labium: prementum with setae in front of palpi; postmentum with two long setae and several moderately short. Pronotum (Fig. 204) wider than long, narrowed anteriad; strongly convex; lateral margins carinate; anterior margin strongly notched; hind angles long, backwards, carinate; median basal tubercle indistinct; punctuation small and dense. Prosternal channel absent. Prosternal spine (Fig. 187) with narrowed apex and subapical lobe or not. Borders of mesosternal (Fig. 186) cavity raised at base and vertical. Metacoxal plate normal, moderately narrowed laterally; free margin straight or with small lobe. Tibial spurs small; tarsomeres 1-3 lamellate beneath. Scutellum elongate with posterior margin rounded. Elytra convex; striae punctuate and grooved; interstices equal and flat.

Male. Tergite 8 (Fig. 312) subtriangular with distal margin rounded; punctuate and marginate by setae; clothed with microtrichiae. Sternite 8 (Fig. 273) transverse, translucent with sclerotized transverse narrow band near base; anterior margin straight with rounded angles; setae concentrate near angles. Sternite 9: distal half gradually narrow to apex and setous. Tergite 9 (Fig. 331) strongly notched at middle; punctuate with setae concentrate near angles; tergite 10 longer than 9 with distal margin rounded; with lateral setae at distal half. Aedeagus (Figs. 374, 375) short and wide; basal piece as long as parameres; parameres fused ventrally; median lobe narrow, slightly longer than parameres; apex of parameres securiform with external margin rounded.

Female. Tergite 8 subtrapezoidal, densely setous. Sternite 8 (Fig. 467) subpentagonal with short setae longer at margins and more concentrate near middle; spiculum gastrale 2.84 times sternite length. Ovipositor with stylus; bursa copulatrix (Fig. 496) with 6 spiny areas, some disposed star-like.

Material examined. GUYANA. Ex-coll. Fleutiaux, 1 ex. (MNHN). FRENCH GUIANA. [Saint Laurent du] Maroni, ex-coll. Le Moult, 1 ex. (MNHN); Kourou, 1 ex. (MHNH). BRAZIL. Pará: Mocambo, 1 M (MZSP); P. Museu, 1 F (MZSP).

Achrestus venustus Champion, 1895

(Figs. 4, 102, 188, 205, 376, 377, 468).

Achrestus venustus Champion, 1895: 340; Fleutiaux, 1902: 114; Schenkling, 1925: 100 (cat.); Blackwelder, 1944: 291 (cat.).

Achrestus lamellicornis Schwarz, 1902: 140; Fleutiaux, 1907: 162.

Length: 10.0-13.5 mm. General integument black or darkbrown and yellow; frons black with median anterior triangular 


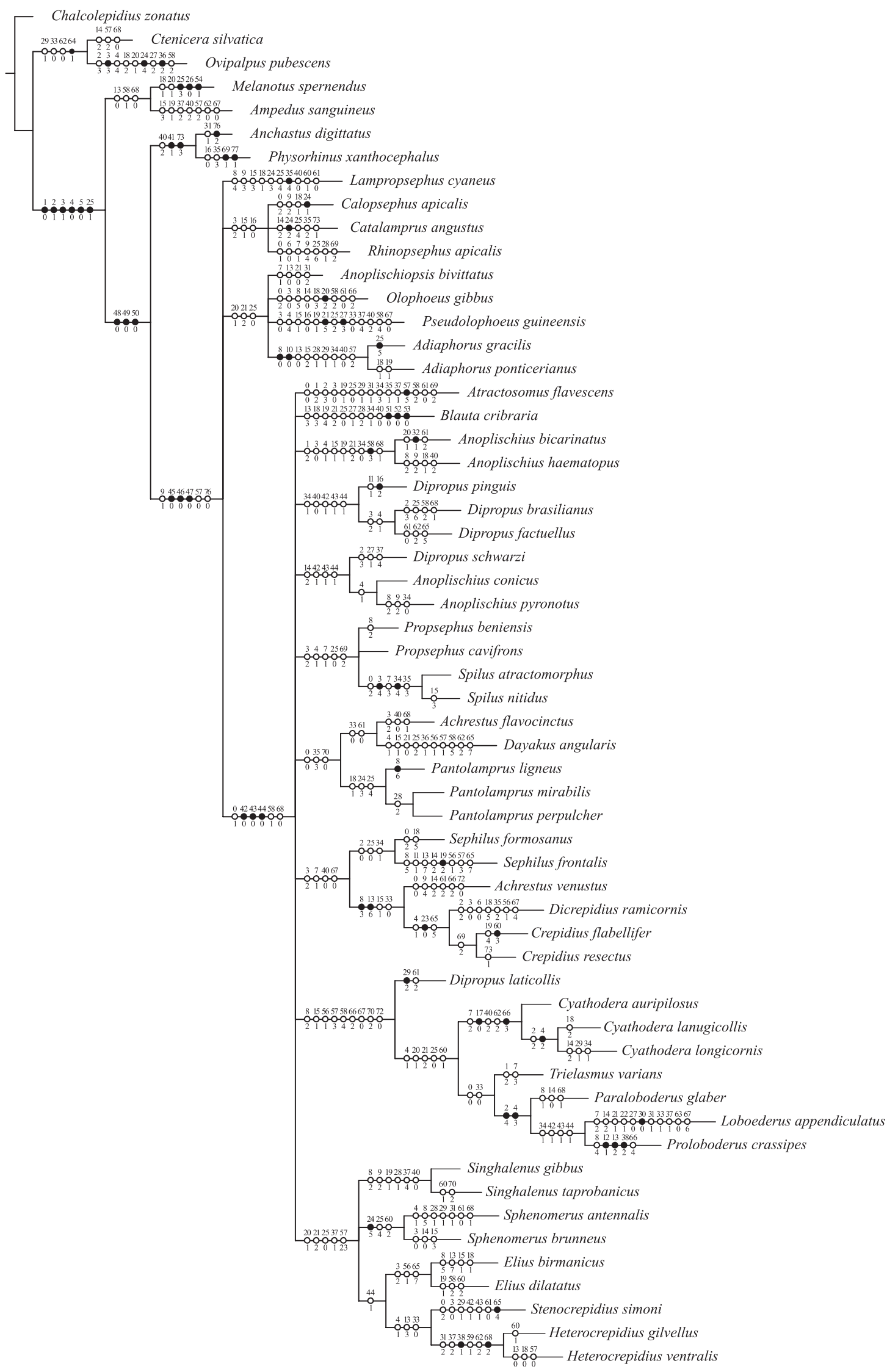

Fig. 2. Tree representing the common clades among five trees calculate with fits 5-50. (open circles = homoplasies; black circles = synapomorphies). 
spot yellow; pronotum black with 3 narrow longitudinal yellow bands: one median and 2 lateral; hypomera dark-brown with margins yellow; prosternum yellow except prosternal spine dark-brown; elytra with a yellow spot each anterior angle and a transversal band near distal third; scutellum yellow bordered black; remainder areas including antennae dark-brown. Pubescence dense and long, accompanying integument color. Frons carinate, wider than long, wider frontally; concave medioanteriorly in a triangular area; anterior margin prominent and surpassing nasal; punctuation moderately coarse and dense. Nasal longer than wide. Antennae (Fig. 4) with 11 antennomeres; flabellate in male and pectinate in female; in male 3.5 antennomeres longer than hind angles of pronotum; scape shorter than eye; $2^{\text {nd }}$ antennomere globular, $3^{\text {rd }}$ with lateral appendix, as long as $4^{\text {th }}$, last with rounded apex. Labrum subrectangular with anterior angles rounded and long setae. Mandibles (Fig. 102) robust, with one apical and one subapical tooth; penicillus formed by short setae disposed in whole mesal area; molar area well developed; dorsal region with carina and moderadely long setae. Maxillae: galea with spatulate and spiniform setae; last palpomere securiform. Labium: prementum with setae in front of palpi; postmentum with two long setae and several moderately short. Pronotum (Fig. 205) wider than long, narrowed anteriad and at hind angles base; strongly convex; lateral margins incompletely carinate; anterior margin slightly notched; hind angles divergent and carinate; median basal tubercle flat; punctuation moderately coarse and very dense, sparser on yellow integument. Prosternal channel absent. Prosternal spine (Fig. 188) sharpened with subapical lobe. Borders of mesosternal cavity declivous. Metacoxal plate moderately narrowed laterally; free margin with small lobe. Tibial spurs small; tarsomeres 1-3 lamellate beneath. Scutellum elongate, narrowed apicad. Elytra convex; striae punctuate and grooved; interstices, flat, equal and punctuate.

Male. Tergite 8 elongate with distal margin rounded; punctuate and marginate by setae; clothed with microtrichiae. Sternite 8 transverse with anterior angles rounded; translucent in irregular area on basal half; setae concentrate on distal half. Sternite 9: distal half gradually narrow to apex and setous. Tergite 9 strongly notched at middle; punctuate with setae concentrate near angles; tergite 10 longer than 9 with distal margin rounded; with lateral setae at distal half. Aedeagus (Figs. 376, 377) long and narrow; basal piece longer than parameres; parameres fused ventrally; median lobe almost straight, constricted at apex, longer than parameres; apex of parameres securiform with external margin rounded.

Female. Tergite 8 elongate, slightly narrowed apicad, setous. Sternite 8 (Fig. 468) elongate, distal half gradually narrowed apicad; short specially on distal half; spiculum gastrale 5 times sternite length. Ovipositor with stylus; bursa copulatrix membranous, without spines.

Material examined. BRAZIL. Rondônia: Vilhena, 1 M, 1 F (DZUP). Amazonas: Benjamin Constant, 1 F (MZSP). Goiás. Jataí, 2 exs (MNHN). São Paulo: Castilho, margem esquerda do rio Paraná, 1 M (MZSP). Peru. Cumbase, ex-coll. Fleutiaux, 1 ex. (MNHN). Bolivia. Santa Cruz, 1 ex. (MNHN).
Adiaphorus Candèze, 1859

Adiaphorus Candèze, 1859: 9, 47; 1891: 57 (cat.); Schwarz, 1906: 60, 71; Schenkling, 1925: 83 (cat.).

Type-species: Adiaphorus gracilicornis Candèze, 1859, designated by Hyslop, 1921.

Candèze (1859) erected Adiaphorus to two species from East Indies and included it in "Dicrépidiites".

Candèze (1891) catalogued 3 species to this genus; Schenkling (1925) catalogued 6.

Schwarz (1906) included 6 species into the genus.

Fleutiaux (1942) described A. malaisei.

Vats \& Chauhan (1992) described two new species from North India.

The genus is composed by 9 species: Adiaphorus elevatus Vats \& Chauhan, 1992, A. gracilicornis Candèze, 1859, A. gracilis Schwarz, 1901, A. levisus Vats \& Chauhan, 1992, A. malaisei Fleutiaux, 1942, A. modestus Candèze, 1892, A. parallelus Schwarz, 1901, A. ponticerianus Candèze, 1859(=Elius rufus Schwarz, 1902, =Adiaphorus rufus Schwarz, 1906) and A. punctatus Duviv., 1890. It is recorded from India and Sri Lanka.

The Adiaphorus species included in this analysis form a monophyletic group. It makes a polytomy with Anoplischiopsis bivittatus, Olophoeus gibbus and Pseudolophoeus guineensis. It is characterized by synapomorphies, $8(0)$ antennae of male filiform and 10(0) antennomeres cylindrical, and by homoplasies, 13(0) $3^{\text {rd }}$ antennomere of male elongate, cylindrical, 15(2) antennae of male more than 4.5 antennomeres longer than hind angles of pronotum, 28(1) pronotum longer than wide, 29(1) hind angles of pronotum divergent, 34(1) prosternal spine with rounded apex, 40(0) tibial spurs short and 57(2) anterior margin of sternite 8 of male straight with prominent angles.

Adiaphorus gracilis Schwarz, 1901

(Figs. 5, 55, 103, 332, 378, 379).

Adiaphorus gracilis Schwarz, 1901: 22; Schenkling, 1925: 83 (cat.).

Length: 7.5-9.0 mm. General integument brown; elytra brownish-yellow with lateral band brown, 4 interstices wide; legs clearer than general integument. Pubescence yellowish, moderately long and dense. Frons carinate, wider than long, convex; anterior margin wide, surpassing nasal; punctuation small and dense. Nasal wider than long. Antennae (Fig. 5) with 11 antennomeres; in male 5.2 antennomeres longer than hind angles of pronotum; filiform, cylindrical; scape shorter than eye; $2^{\text {nd }}$ antennomere globular, $3^{\text {rd }}$ elongate, shorter than $4^{\text {th }}$, last with rounded apex. Labrum (Fig. 55) semielliptical with long setae. Mandibles (Fig. 103) narrow, with one apical and one small subapical tooth; penicillus formed by short setae disposed in whole mesal area; dorsal region with carina and moderadely long setae. Maxillae: galea with simple setae; last palpomere slightly widened apicad. Labium: prementum with 
setae in front of palpi disposed in 2 inclined rows; postmentum with 2 long and several moderately short setae. Pronotum strongly longer than wide, almost subrectangular; strongly convex; anterior margin almost straight; lateral carina not visible dorsally; hind angles divergent and carinate; median basal tubercle flat; punctuation small and dense. Prosternal channel short. Prosternal spine with rounded apex. Borders of mesosternal cavity declivous. Metacoxal plate strongly narrowed laterally; free margin with small lobe. Tibial spurs small; tarsomeres 2-3 lamellate beneath. Scutellum elongate, triangular. Elytra convex; striae coarsely punctuate; interstices equal and slightly convex.

Male. Tergite 8 elongate with distal margin rounded; punctuate and marginate by setae; clothed with microtrichiae. Sternite 8 transverse with anterior angles prominent; translucent except narrow lateral band yellow. Sternite 9: distal half gradually narrow to apex and setous. Tergite 9 (Fig. 332) strongly notched at middle (V-shaped); sparsely punctuate with moderately long setae concentrate near angles; tergite 10 shorter than 9 with setae near apex. Aedeagus (Figs. 378, 379): basal piece shorter than parameres; parameres fused ventrally; median lobe narrow, gradually narrowed apicad, apex rounded, slightly longer than parameres; apex of parameres cuneiform, notched at base.

Material examined. SRI LANKA. (Ceylon) Kandy 2 exs (MNHN)

Adiaphorus ponticerianus Candèze, 1859

(Figs. 56, 104, 206, 274, 333, 380, 381).

Adiaphorus ponticeranus Candèze, 1859: 48; 1891: 57 (cat.); Schenkling, 1925: 83 (cat.).

Elius rufus Schwarz, 1902: 223

Adiaphorus rufus; Schwarz, 1906: 72.

Length: 10.5-11.0 mm. General integument yellowishbrown; antennae sometimes darker and legs clearer than general integument. Pubescence yellowish, thin, moderately long and dense. Frons carinate, longer than wide, convex; anterior margin wide, surpassing nasal; punctuation small and dense. Nasal wider than long. Antennae with 11 antennomeres; in male 5.5 antennomeres longer than hind angles of pronotum; filiform, cylindrical; scape shorter than eye; $2^{\text {nd }}$ antennomere globular, $3^{\text {rd }}$ elongate, shorter than $4^{\text {th }}$, last with rounded apex. Labrum (Fig. 56) semicircular, notched at middle, with long setae. Mandibles (Fig. 104) narrow, with one apical and one small subapical tooth; penicillus formed by short setae disposed in whole mesal area; dorsal region with carina and moderadely long setae. Maxillae: galea with simples etae; last palpomere slightly widened at apex. Labium: prementum with setae in front of palpi disposed in 2 transverse rows; postmentum with 2 long and several moderately short setae. Pronotum (Fig. 206) strongly longer than wide, almost subrectangular; strongly convex; anterior margin almost straight; lateral carina not visible dorsally; hind angles strongly divergent and carinate; median basal tubercle flat; punctuation small and dense. Prosternal channel short. Prosternal spine with rounded apex. Borders of mesosternal cavity declivous.
Metacoxal plate strongly narrowed laterally; free margin with small lobe. Tibial spurs small; tarsomeres 2-3 lamellate beneath. Scutellum elongate, triangular. Elytra convex; striae coarsely punctuate; interstices equal and slightly convex.

Male. Tergite 8 elongate with distal margin rounded; punctuate and marginate by setae; clothed with microtrichiae. Sternite 8 (Fig. 274) transverse with anterior angles prominent; translucent except narrow lateral yellow band. Sternite 9: distal half gradually narrow to apex and setous. Tergite 9 (Fig. 333) strongly notched at middle; sparsely punctuate with moderately long setae concentrate near angles; tergite 10 shorter than 9 with some very short setae. Aedeagus (Figs. 380, 381): basal piece shorter than parameres; parameres fused ventrally; median lobe narrow, gradually narrowed apicad, slightly longer than parameres with rounded apex; apex of parameres cuneiform, notched at base.

Material examined. INDIA. Fraserpet [Kushalnagar], 2 exs (MNHN); Madura 3 exs (MNHN); Shembaganur 10 exs. (MNHN). Nilguiri Hills, 6 exs (MNHN). Locality not found: Indi ohury 1 (MNHN).

\section{Anoplischiopsis Champion, 1895}

Anoplischiopsis Champion, 1895: 301; Schwarz, 1906: 59, 69; Schenkling, 1925: 81 (cat.); Blackwelder, 1944: 298 (cat.).

Type-species: Anoplischiopsis bivittatus Champion, 1895, designated by Hyslop, 1921.

Champion (1895) erected Anoplischiopsis to 6 new species from Central America and also Ischiodontus crocicollis Candèze, 1859 from Colombia. He presented a key for CentralAmerican species.

Schwarz (1906) included 7 species into the genus.

Schenkling (1925) and Blackwelder (1944) catalogued 8 species to Anoplischiopsis and did not include Ischiodontus crocicollis.

The genus Anoplischiopsis is composed by 9 species: A. basimaculatus Champion, 1895, A. bivittatus Champion, 1895, A. crocicollis (Candèze, 1859), A. divisa Schwarz, 1898, A. flavovittatus Champion, 1895, A. fuscipennis Champion, 1895, A. lineatocollis Champion, 1895, A. luteus Champion, 1895 and A. trinotaus Champion, 1896. It is recorded from North America (Mexico) and Central America (Nicaragua, Costa Rica, Panama).

Anoplischiopsis bivittatus forms a polytomy with Olophoeus gibbus, Pseudolophoeus guineensis and Adiaphorus. It is characterized especially by homoplasies, 7(1) nasal longer than wide, 13(0) antennomere 3 of male elongate, cylindrical, 21(0) mesal area of mandibles with one apical tooth and 31(2) carina of hind angles of pronotum weak.

\section{Anoplischiopsis bivittatus Champion, 1895}

(Figs. 8, 209).

Anoplischiopsis bivittatus Champion, 1895: 301; Schenkling, 1925: 81 (cat.)

Length: 6.8-7.3 mm. General integument brownish with legs, 


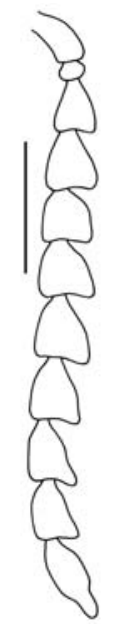

3

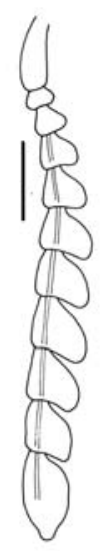

12

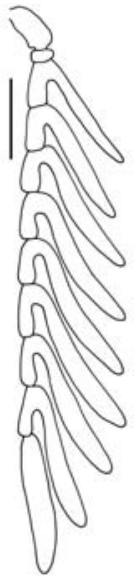

4

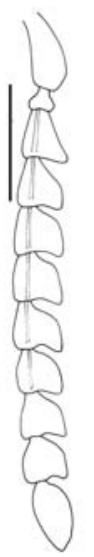

13

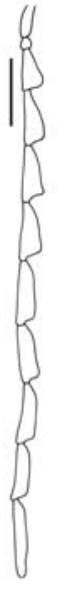

21
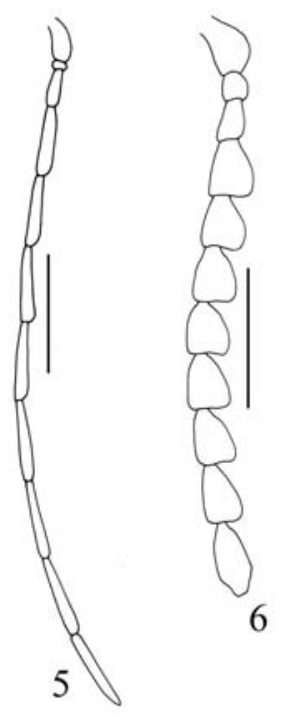

6

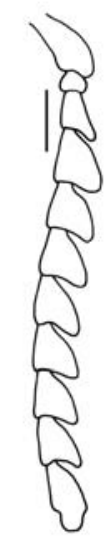

14
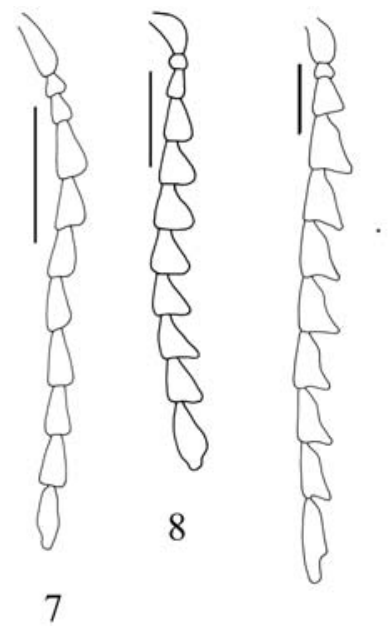

9

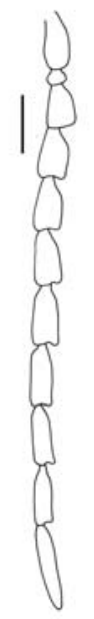

16

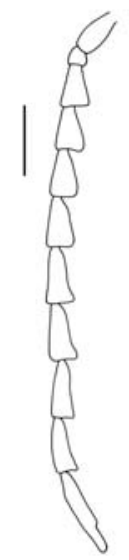

17
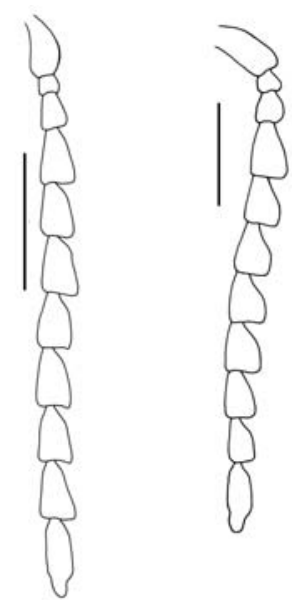

11

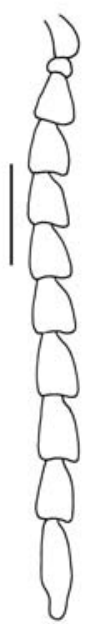

19

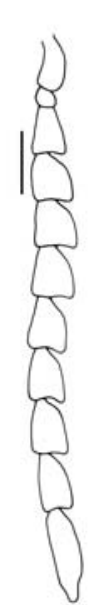

20

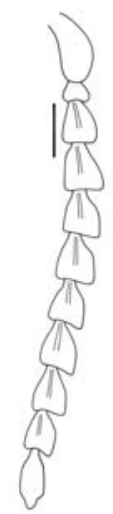

22

15

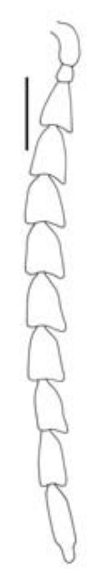

18

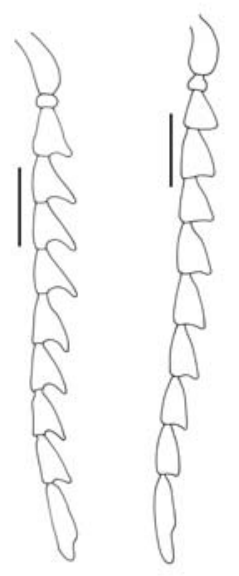

23

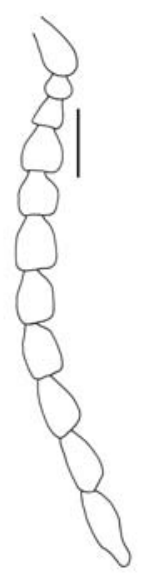

25

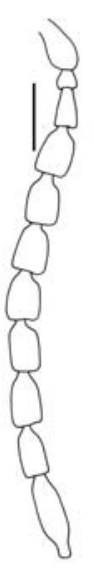

26

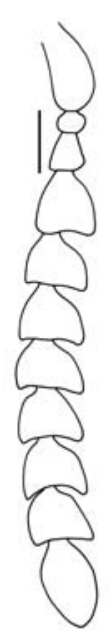

27

Figs. 3-27. Antenna: 3, Achrestus flavocinctus; 4, Achrestus venustus; 5, Adiaphorus gracilis; 6, Ampedus sanguineus; 7, Anchastus digittatus; 8, Anoplischiopsis bivittatus; 9, Anoplischius bicarinatus; 10, Atractosomus flavescens; 11, Blauta cribraria; 12, Calopsephus apicalis; 13, Catalamprus angustus; 14, Chalcolepidius zonatus; 15, Ctenicera silvatica; 16, Cyathodera lanugicollis; 17, Cyathodera longicornis; 18, Dayakus angularis; 19, Dipropus brasilianus; 20, Dipropus factuellus; 21, Dipropus laticollis; 22, Dipropus pinguis; 23, Elius birmanicus; 24, Elius dilatatus; 25, Heterocrepidius gilvellus; 26, Heterocrepidius ventralis; 27, Lampropsephus cyaneus. Bars = 1 mm. 
hind angles of pronotum and a longitudinal band on elytra yellowish; band of elytra 2.5 interstices wide and $2 / 3$ of elytral length. Pubescence thin, long and dense, accompanying integument color. Frons carinate, wider than long; convex; anterior margin slightly rounded, not surpassing nasal; punctuation moderately coarse and dense. Nasal very narrow, much wider than long. Antennae (Fig. 8) with 11 antennomeres, strongly serrate; in male 2 antennomeres longer than hind angles of pronotum; scape shorter than eye; $2^{\text {nd }}$ antennomere globular; $3^{\text {rd }}$ cylindrical, elongate, shorter than $4^{\text {th }}$; last with narrowed apex. Labrum semielliptical with long setae. Mandibles with apical tooth. Last palpomere maxillar ovalar. Pronotum (Fig. 209) wider than long, narrowed anteriad; moderately convex on anterior $2 / 3$, declivous on basal $1 / 3$; lateral margins incompletely carinate; anterior margin notched; hind angles backwardly directed and weakly carinate; median basal tubercle flat, preceeded by carina; punctuation moderately coarse and dense on anterior half and small and sparser on basal half. Prosternal channel long. Prosternal spine with subapical lobe. Borders of mesosternal cavity narrow and declivous. Metacoxal plate moderately narrowed laterally; free margin with small lobe. Tibial spurs long; tarsomeres 2-3 lamellate beneath. Elytra moderately convex, slightly narrowed on distal half; striae coarsely punctuate and grooved; interstices slightly convex.

Material examined. COSTA RICA. Turrialba, ex-coll. Fleutiaux, 3 exs (MNHN). PANAMA. Chiriqui: Volcan de Chiriqui, 25-4000 ft, Champion, 1 ex. (ISNB); B.C.A. Col. III(1), 1 ex (MNHN).

\section{Anoplischius Candèze, 1859}

Anoplischius Candèze, 1859: 9, 45; 1891: 57 (cat.); Champion, 1895: 305; Schwarz, 1906: 59, 66; Fleutiaux, 1907: 174; Schenkling, 1925: 78 (cat.); Blackwelder, 1944: 297 (cat.).

Dipropus (pars) Germar, 1839: 215; Lacordaire, 1857: 172.

Heterocrepidius (pars) Lacordaire, 1857: 170.

Oxycleidius Eschscholtz, 1836: tab.

Type-species: Anoplischius pallidipes Candèze, 1859, designated by Hyslop, 1921.

Candèze (1859) erected Anoplischius to included 39 new species, one removed from Cyathodera and one from Dicrepidius, totalizing 41 species. He divided the genus in 4 sections according to the length and structures of antennae, and the shapes of prothorax and nasal plate.

Candèze (1891) considered Dipropus Germar (pars) as synonym of Anoplischius. He catalogued 54 American species except one, A. laminatus Candèze, 1859, from Ceylon. He separated the species in three groups based on: a) antennae shorter than half of body length; b) antennae very long and c) hind angles of pronotum straight or curved inward bearing strong carina.

Champion (1895) described 8 new species.

Schwarz (1906) included into the genus, 94 species divided in three groups and 3 species in the subgenus Cyathodera.

Fleutiaux (1907) recharacterized the genus and stated that it comprehends 90 species. He also decribed Anoplischius candezei based on one specimen named as "Ovipalpus (Anoplischius) pubescens Solier".

Hyslop (1921) designated Anoplischius pallidipes Candèze as the type species of the genus.

Schenkling (1925) catalogued 102 species to this genus including 3 of subgenus Cyathodera.

Blackwelder (1944) catalogued 101 species to genus.

The genus Anoplischius is composed by about 110 species. It is recorded from North America (Mexico), Central America (Belize, Guatemala, Nicaragua, Panama), Antilles (Cuba, Hispaniola, Guadeloupe), South America (Colombia, Venezuela, Guyana, French Guiana, Brazil, Ecuador, Peru, Bolivia, Chile, Argentina).

The Anoplischius species included in this analysis do not form a monophyletic group. The group ((A.bicarinatus) $(A$. haematopus)) is characterized by sinapomorphy 58(3) distal margin of tergite 9 of male widely notched at middle and by homoplasies, 1(2) frontal carina incomplete, 3(0) anterior margin of frons at nasal level, 4(1) median anterior region of frons concave, 15(1) antennae of male 2.5-4.4 antennomeres longer than hind angles of pronotum, 19(1) anterior margin of labrum notched at middle, 21(2) mesal area of mandibles with one apical and one subapical tooth distant of apex, 34(0) prosternal spine with bilobed apex and 68(1) apex of median lobe rounded. It belongs to a polytomy formed by some genera and several groups of genera. The group $((A$. conicus $)(A$. pyronotus)) is characterized by homoplasy, 4(1) median anterior region of frons concave. It is the sister-group of Dipropus schwarzi and also belongs to the anterior polytomy. The type-species of this genus was not studied and the species analysed are insufficient to establish a new genus.

Anoplischius bicarinatus Candèze, 1859

(Figs. 9, 59, 109, 190, 210, 335, 384, 385).

Anoplischius bicarinatus Candèze, 1859: 62; 1891: 58 (cat.); Schenkling, 1925: 78 (cat.); Blackwelder, 1944: 297 (cat.)

Length: 19-22 mm. General integument reddish-brown with antennae and legs clearer. Pubescence yellowish, very long, thin and moderately dense. Frons incompletely carinate, wider than long, concave medioanteriorly; anterior margin not prominent; punctuation moderately coarse and dense. Nasal wider than long. Antennae (Fig. 9) with 11 antennomeres; in male 3 antennomeres longer than hind angles of pronotum; serrate; scape shorter than eye; $2^{\text {nd }}$ antennomere globular, $3^{\text {rd }}$ triangular, shorter than $4^{\text {th }}$, last narrowed at apex. Labrum (Fig. 59) semielliptical, notched at middle, with long setae. Mandibles (Fig. 109) narrow with one apical and one subapical tooth; penicillus formed by short setae disposed in whole mesal area; molar area well developed; dorsal region with carina and moderadely long setae. Maxillae: galea with spatulate setae; last palpomere securiform. Labium: prementum with setae in front of palpi; postmentum with two long setae and many moderately short. Pronotum (Fig. 210) wider than long, strongly convex frontally; convexity decreasing basad; lateral margins carinate; anterior margin slightly prominent at middle; 

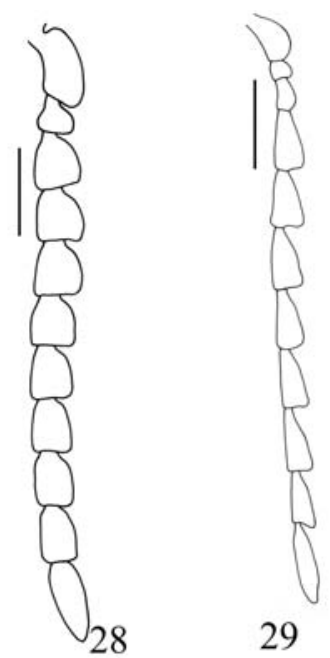

29

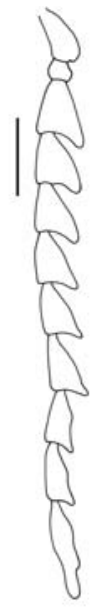

30

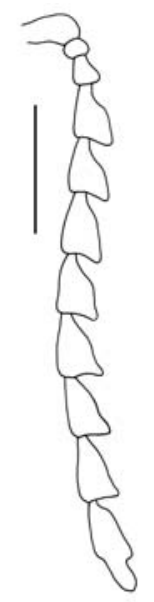

31

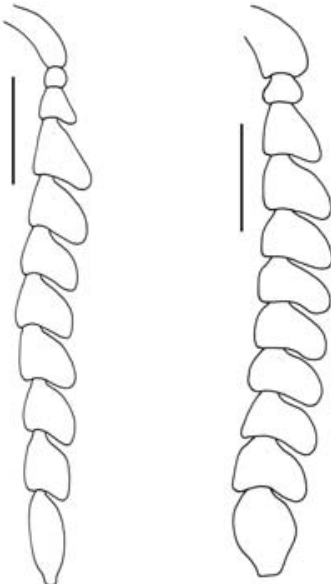

32

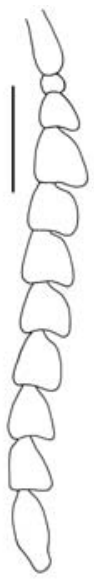

34

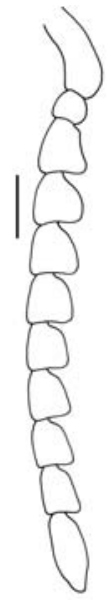

35

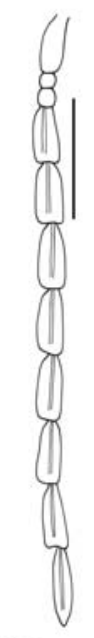

36

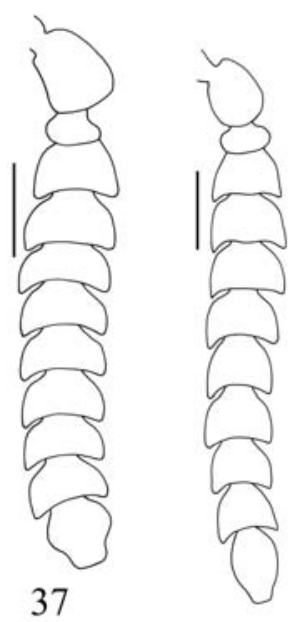

38

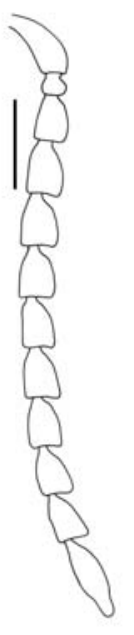

39

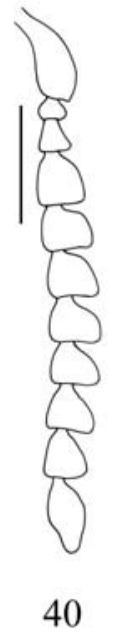

40

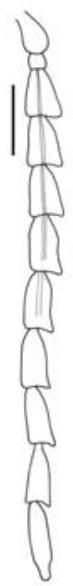

41

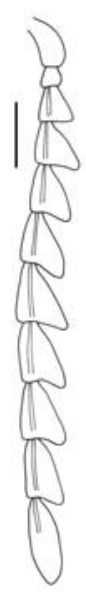

42

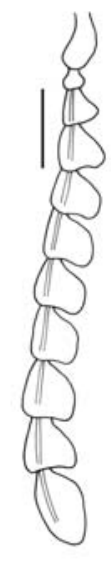

43

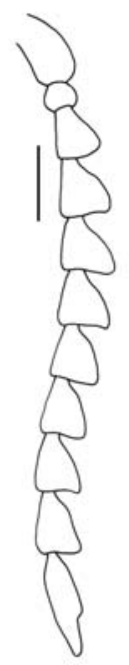

44

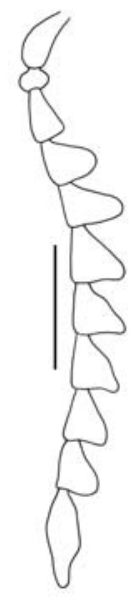

50

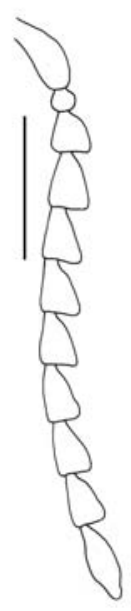

51
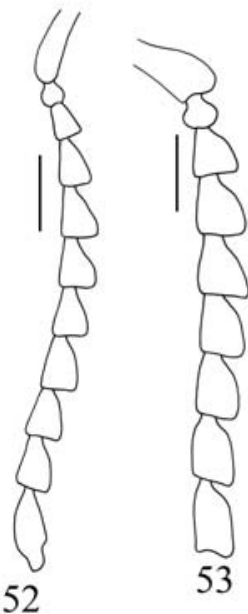

Figs. 28-53. Antenna: 28, Loboederus appendiculatus; 29, Melanotus spernendus; 30, Olophoeus gibbus; 31, Ovipalpus pubescens; 32, Pantolamprus ligneus; 33, Pantolamprus mirabilis; 34, Pantolamprus perpulcher; 35, Paraloboderus glaber; 36, Physorhinus xanthocephalus; 37, 38, Proloboderus crassipes (F, M); 39, Propsephus beniensis; 40, Propsephus cavifrons; 41, Pseudolophoeus guineensis; 42, 43, Rhinopsephus apicalis (M, F); 44, Sephilus formosanus; 45, 46, Sephilus frontalis (M, F); 47, Singhalenus gibbus; 48, Singhalenus taprobanicus; 49, Sphenomerus antennalis; 50, Sphenomerus brunneus; 51, Spilus atractomorphus; 52, Spilus nitidus; 53, Trielasmus varians. Bars = 1 mm. 
hind angles backwardly directed, bicarinate; median basal tubercle indistinct; punctuation coarse and dense. Prosternal channel long. Prosternal spine (Fig. 190) with bilobed apex. Borders of mesosternal cavity narrow and declivous. Metacoxal plate strongly narrowed laterally; free margin straight. Tibial spurs long; tarsomeres 1-3 lamellate beneath. Scutellum elongate, narrowed apicad; distal margin rounded. Elytra convex, slightly narrowed at apex; striae grooved at base, marked by weak punctuation; interstices convex at base and near apex; remainder area flat.

Male. Tergite 8 elongate, subtriangular, with short setae on distal half; clothed with microtrichiae. Sternite 8 translucent, slightly sclerotized laterally and in a small transverse median basal area; anterior margin straight and anterior angles rounded; setae more concentrate near angles. Sternite 9: distal half slightly narrowed apicad; short setae on distal half. Tergite 9 (Fig. 335) widely notched at middle; setae moderately long laterally, near angles; tergite 10 wide, longer than 9 , with setae near margins. Aedeagus (Figs. 384, 385): short and wide; basal piece shorter than parameres; parameres fused ventrally; median lobe narrowed apicad.

Material examined. BRAZIL. Goiás: Campinas, 2 exs (MZSP); Vianópolis, 1 ex. (MZSP). São Paulo: São Paulo (Ipiranga), 1 ex. (MZSP); St. Paul; coll. Chevrolat; bicarinatus Cand. Type; Anoplischius bicarinatus Cand. Type Fleutiaux (MNHN).

\section{Anoplischius conicus Candèze, 1900}

Anoplischius conicus Candèze, 1900: 8; Schenkling, 1925: 78 (cat.); Blackwelder, 1944: 297 (cat.).

Length: 10.5-12.0 mm. General integument bright, darkbrown and yellowish: head dark-brown, prothorax and legs yellow; antennae brownish; anterior half of elytra yellow; remainder areas dark-brown. Pubescence long, yellow and moderately dense. Frons carinate, longer than wide; slightly grooved longitudinal medially and near anterior margin; anterior margin rounded, surpassing nasal; punctuation moderately coarse and sparse. Nasal wider than long. Antennae with 11 antennomeres; in male very long, 5.25 antennomeres longer than hind angles of pronotum; serrate in both sexes; scape shorter than eye; $2^{\text {nd }}$ antennomere globular; $3^{\text {rd }}$ triangular, as long as $4^{\text {th}}$; last with narrowed apex. Labrum semicircular with long setae. Maxillae: last palpomere securiform. Pronotum wider than long, narrowed anteriorly and at hind angles base; slightly convex; lateral margins incompletely carinate; anterior margin U-shaped; hind angles backwardly directed and carinate; median basal tubercle flat; punctuation small and sparse. Prosternal channel present. Prosternal spine with subapical lobe. Borders of mesosternal cavity slightly declivous, almost horizontal. Metacoxal plate strongly narrowed laterally; free margin straight. Tibial spurs long; tarsomeres 2-3 lamellate beneath. Scutellum pentagonal with posterior margin rounded. Elytra gradually narrowed apicad; striae distinct only at base; interstices convex at base.
Material examined. BOLIVIA. Coroico, ex-coll. Fleutiaux, 1 ex. (MNHN); S. Antonia, ex-coll. Fleutiaux, 1 ex. (MNHN).

Anoplischius haematopus Candèze, 1859

(Figs. 60, 110, 211, 276, 313, 336, 386, 387).

Anoplischius haematopus Candèze, 1859: 64; 1891: 58 (cat.); Heyne \& Taschenberg, 1908: 156; Schenkling, 1925: 79 (cat.); Blackwelder, 1944: 298 (cat.).

Length: 23-30 mm. General integument reddish darkbrown; legs and antennae clearer. Pubescence yellowish, long and moderately long. Frons incompletely carinate, as long as wide, slightly concave medioanteriorly; anterior margin not prominent; punctuation moderately coarse and dense. Nasal wider than long. Antennae with 11 antennomeres; in male 3 antennomeres longer than hind angles of pronotum; subserrate in both sexes; scape shorter than eye; $2^{\text {nd }}$ antennomere globular, $3^{\text {rd }}$ triangular elongate, shorter than $4^{\text {th }}$, last narrowed at apex. Labrum (Fig. 60) semicircular; anterior margin excavate at middle; with long setae. Mandibles (Fig. 110) wide with one apical and one subapical rounded tooth; penicillus formed by short setae disposed in whole mesal area; molar area well developed; dorsal region with carina and moderadely long setae. Maxillae: galea with spatulate setae; last palpomere securiform. Labium: prementum with setae in front of palpi; postmentum with two long setae and many moderately short. Pronotum (Fig. 211) wider than long, strongly convex frontally; convexity decreasing basad; lateral margins carinate; anterior margin slightly prominent at middle; hind angles backwardly directed with weak carina; median basal tubercle indistinct; punctuation moderately coarse, dense and heterogeneous. Prosternal channel long. Prosternal spine with apex bilobed. Borders of mesosternal cavity narrow and declivous. Metacoxal plate strongly narrowed laterally; free margin straight. Tibial spurs very long; tarsomeres 1-3 lamellate beneath. Scutellum subpentagonal elongate. Elytra convex, gradually narrowed to apex with sutural spine; striae marked by punctuation; interstices slightly convex.

Male. Tergite 8 (Fig. 313) elongate, narrowed to apex; with short setae on distal half; clothed with microtrichiae. Sternite 8 (Fig. 276) transverse with anterior angles rounded; translucent with a transverse basal sclerite and irregular darker lateral bands; setae more concentrate near lateral margins. Sternite 9: distal half gradually narrowed to apex; setous on distal half. Tergite 9 (Fig. 336) widely notched at middle; moderately long setae laterally near angles; tergite 10 longer than 9, wide with setae near margins. Aedeagus (Figs. 386, 387) narrow; basal piece shorter than parameres; parameres fused ventrally; median lobe narrow, slightly longer than parameres, narrowed to apex; apex of parameres securiform.

Material examined. BRAZIL. Goiás: Vianópolis, 1 ex. (MZSP). São Paulo: São Paulo, 1 ex. (MZSP); (Ipiranga), 1 ex. (MZSP). Without locality: 2 exs. (MZSP). 

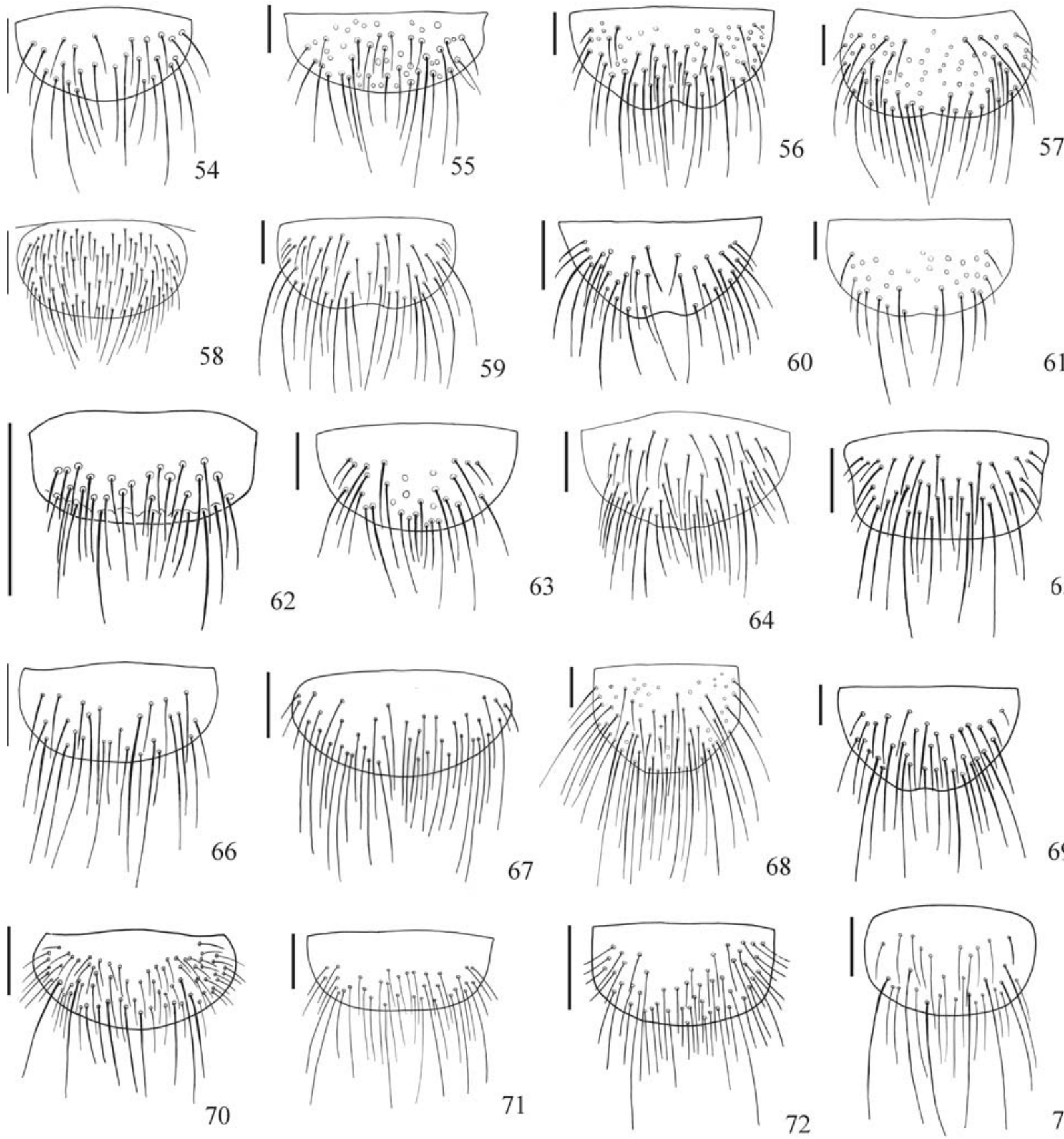

73
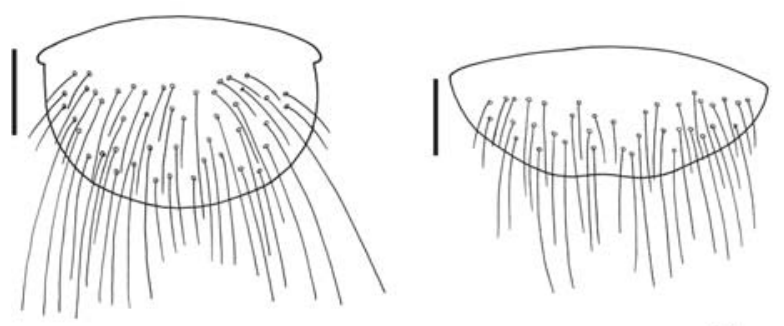

74

75
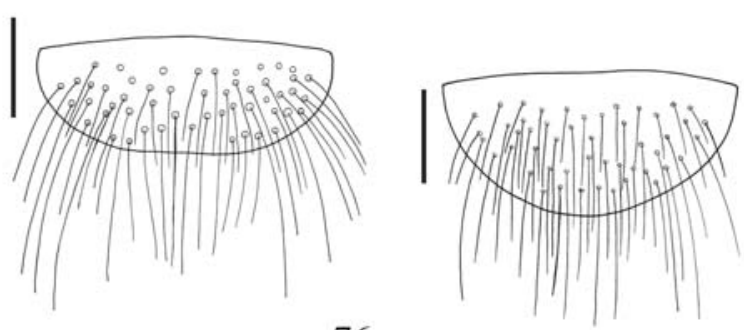

Figs. 54-77. Labrum: 54, Achrestus flavocinctus; 55, Adiaphorus gracilis; 56, Adiaphorus ponticerianus; 57, Ampedus sanguineus; 58, Anchastus digittatus; 59, Anoplischius bicarinatus; 60, Anoplischius haematopus; 61, Atractosomus flavescens; 62, Blauta cribraria; 63, Calopsephus apicalis; 64, Catalamprus angustus; 65, Crepidius flabellifer; 66, Crepidius resectus; 67, Ctenicera silvatica; 68, Cyathodera lanugicollis; 69, Cyathodera longicornis; 70, Dayakus angularis; 71, Dicrepidius ramicornis; 72, Dipropus brasilianus; 73, Dipropus laticollis; 74, Elius birmanicus; 75, Elius dilatatus;76, Heterocrepidius gilvellus; 77, Heterocrepidius ventralis. Bars $=2 \mathrm{~mm}$ except fig. $62=5 \mathrm{~mm}$. 
Anoplischius pyronotus Candèze, 1859

Anoplischius pyronotus Candèze, 1859: 71; 1891: 58 (cat.); Schenkling, 1925: 80 (cat.); Blackwelder, 1944: 298 (cat.).

Length: 8-9 mm. General integument brown with prothorax yellow. Pubescence yellowish and moderately long and dense. Frons carinate, longer than wide, concave at middle near anterior margin; anterior margin rounded and prominent, surpassing nasal; punctuation coarse and dense. Nasal wider than long. Antennae with 11 antennomeres; in male 4.5 antennomeres longer than pronotum; subserrate in both sexes; scape shorter than eye; $2^{\text {nd }}$ antennomere globular; $3^{\text {rd }}$ triangular as long as $4^{\text {th }}$. Labrum semicircular with long setae. Maxillae: last palpomere securiform. Pronotum wider than long, gradually narrowed anteriad; lateral margins carinate; anterior margin almost straight; hind angles backwardly directed and carinate; median basal tubercle flat; punctuation moderately coarse and dense. Prosternal channel present. Prosternal spine with bilobed apex. Borders of mesosternal cavity declivous. Metacoxal plate strongly narrowed laterally; free margin with a tooth. Tibial spurs present, moderately long; tarsomeres 2-3 lamellate beneath. Scutellum elongate, triangular. Elytra convex, narrowed on distal 2/3; striae grooved and punctuate; interstices punctuate and flat.

Material examined. CUBA. Ex-coll. Fleutiaux, 1 ex. (MNHN). Without locality; ex-coll. Fleutiaux, 1 ex. (MNHN).

\section{Asebis Candèze, 1894}

Asebis Candèze, 1894: 487; Schwarz, 1906: 59, 73: Schenkling, 1925: 84 (cat.).

Type-species: Asebis modiglianii Candèze, 1894, by monotypy.

Candèze (1894) erected Asebis based on one specimen "aux bords du lac de Toba" (Sumatra). According to him this genus is near Heterocrepidius. It presents $3^{\text {rd }}$ tarsomere lamellate and $4^{\text {th }}$ very small. Based on tarsi it would be placed into the tribe "Physorhinites", but, the flat frontal shape and the metacoxal plates strongly narrowed and, at the end, the fascies, put it into the Indian "Dicrépidiites", despite of tarsi similar to Anchastus (Physorhinina).

The genus Asebis, monotypical, is recorded from Sumatra.

No specimen of Asebis was examined but, as already observed by Candèze, the presence of tarsomere 3 lamellate indicates that this genus belongs to Physorhinina.

\section{Atractosomus Lacordaire, 1857}

Atractosomus Lacordaire, 1857: 167, 173; Candèze, 1859: 10, 132; Champion, 1895: 297; Schwarz, 1906: 59, 75; Schenkling, 1925: 86 (cat.); Blackwelder, 1944: 299 (cat.).

Atractodes Germar, 1839: 219 (preocc.); Candèze, 1891: 63 (cat.).

Type-species: Atractodes flavescens Germar, 1839, designated by Hyslop, 1921.
Lacordaire (1857) presented a new name to Atractodes Germar, 1839 that was preoccupied in Hymenoptera. He also redescribed the genus and stated about the horizontal shape of mesosternum and the prosternal spine straight, characteristics of the genus. The genus was formed only by A. flavescens (Germar, 1839).

Candèze (1859) redescribed the genus, described 14 new species, presented a key for 15 species and divided it in two sections according to the length of third antennal segment. According to him, Germar (1839) included several species with mesosternum not horizontal, which form the second division. The genus formed by Lacordaire (1857) excludes all species with mesostenum declivous and not corresponds exactly to characters from Germar (l.c.). At the footnote, he stated that some species present a median small tooth at border of hind coxa, but he did not give many importance to this character as he gave in other genera, because Atractosomus is well defined by mesosternal shape.

Candèze (1891) considered Atractosomus as synonym of Atractodes. He catalogued 19 species to this genus, separated into two groups according to $3^{\text {rd }}$ antennomere length.

Champion (1895) described 4 species, A. cribricollis, A. curticollis, A. fusiformis, and A. mucronatus, from Central America. According to him the genus was composed by 21 species, from tropical America.

Schwarz (1906) included 31 species into the genus.

Schenkling (1925) and Blackwelder (1944) catalogued 31 species to this genus.

The genus Atractosomus is formed by 31 species: A. angustus Schwarz, 1904, A. arcuatus Candèze, 1859 (=Atractodes arcuatus Candèze, 1891), A. atricornis (Erichson, 1848), A auricomus Candèze, 1859, A. carinatus Candèze, 1859, A. castaneus Candèze, 1896, A. cayennensis Candèze, 1859, A. colombicus Fleutiaux, 1891, A. conicicollis Candèze, 1859, A. corax Candèze, 1859 (= Atractodes corax Candèze, 1891), A. cratonychoides Candèze, 1859, A. cribricollis Champion, 1895, A. curticollis Champion, 1895, A. dimidiatus Lucas, 1859, A. ferrugineus Candèze, 1859, A. flavescens (Germar, 1839), A. flavipes (Candèze, 1878), A. fusiformis Champion, 1895, A. illinitus (Candèze, 1893), A. infumatus Candèze, 1859, A. luteipennis (Candèze, 1878), A. mucronatus Champion, 1895, A. nigerrimus Schwarz, 1900, A. oertzeni Schwarz, 1902, A. pedestris Schwarz, 1904, A. plebejus Candèze, 1859, A. rhomboidalis Candèze, 1859, A. robustus Candèze, 1859, A. rubidus Candèze, 1859, A. tabularius Candèze, 1859, A. testaceipennis Schwarz, 1904. It is recorded from North America (Mexico), Central America (Guatemala, Nicaragua, Panama), South America (Colombia, Venezuela, Guyana, French Guiana, Brazil, Ecuador).

Atractosomus flavescens is characterized by synapomorphy, 57(5) anterior margin of sternite 8 of male prominent at middle, and by homoplasies, $0(0)$ frons wider than long, 1(2) frontal carina incomplete, 2(3) anterior margin of frons straight, 3(0) anterior margin of frons at nasal level, 19(1) anterior margin of labrum notched at middle, 25(0) setae 

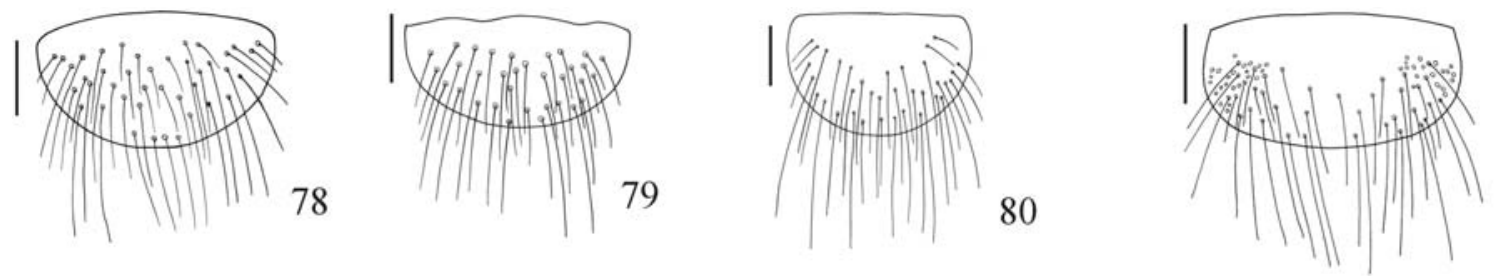

81
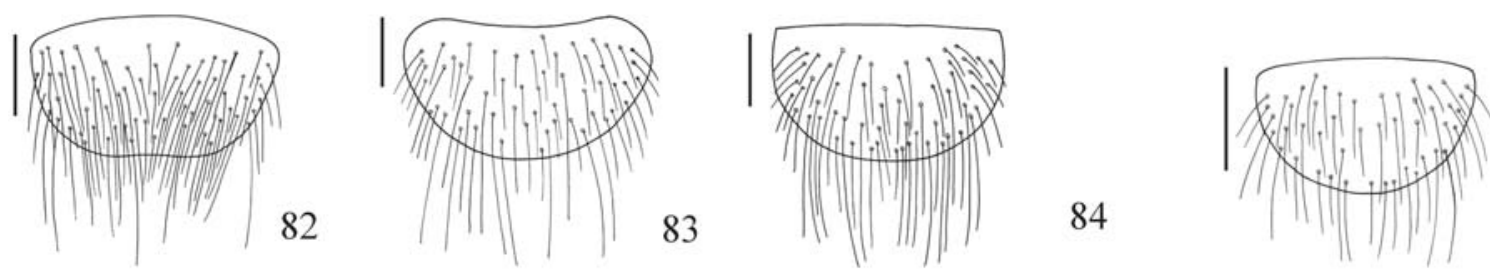

85
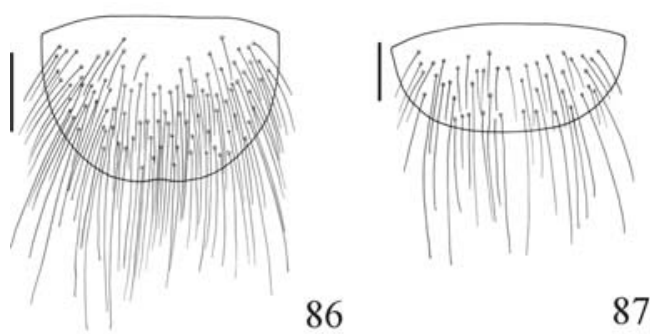

86
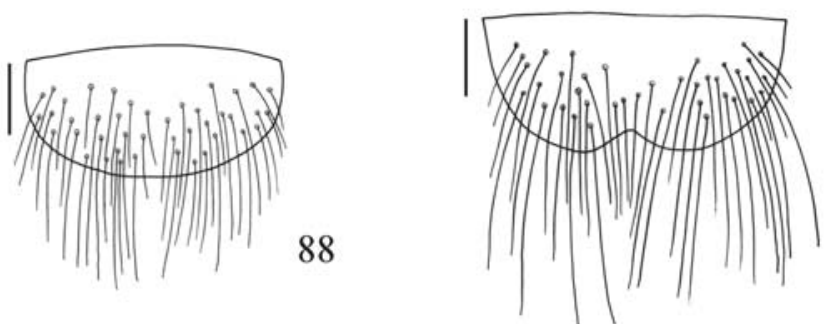

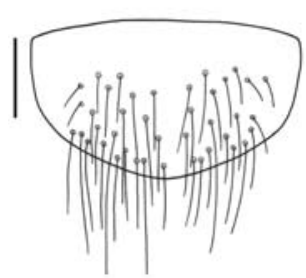

90

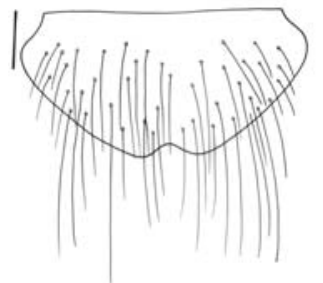

94

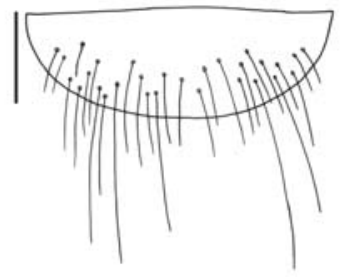

91

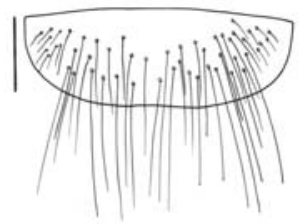

95

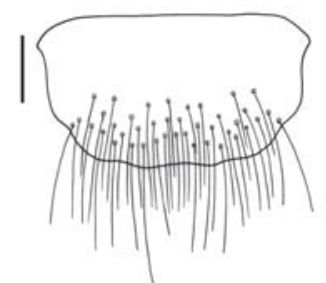

92

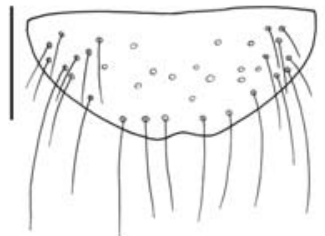

93

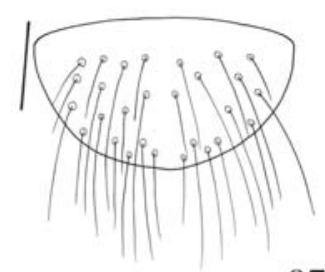

97
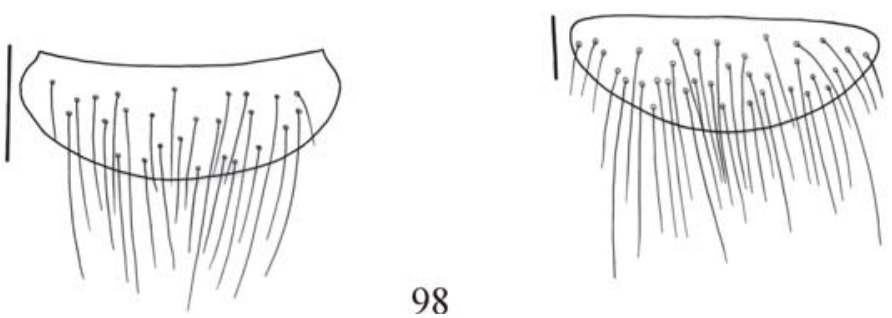

99

98

96

Figs. 78-100. Labrum: 78, Lampropsephus cyaneus; 79, Loboederus appendiculatus; 80, Melanotus spernendus; 81, Olophoeus gibbus; 82, Ovipalpus pubescens; 83, Pantolamprus mirabilis; 84, Pantolamprus perpulcher; 85, Physorhinus xanthocephalus; 86, Proloboderus crassipes; 87, Propsephus beniensis; 88, Propsephus cavifrons; 89, Pseudolophoeus guineensis; 90, Rhinopsephus apicalis; 91, Sephilus formosanus; 92, Sephilus frontalis; 93, Singhalenus gibbus; 94, Singhalenus taprobanicus; 95, Sphenomerus antennalis; 96, Sphenomerus brunneus; 97, Spilus atractomorphus; 98, Spilus nitidus; 99, Stenocrepidius simoni; 100, Trielasmus varians. Bars $=2 \mathrm{~mm}$. 
of galea simple, 29(1) hind angles of pronotum divergent, 31(1) carina of hind angles of pronotum absent, 34(3) prosternal spine with apex widened with tooth, 35(1) borders of mesosternal cavity horizontal, 37(1) free margin of metacoxal plate with small lobe, 58(2) distal margin of tergite 9 of male moderately notched at middle, 61(0) aedeagus short and wide and 69(2) apex of sternite 8 of female widely rounded. It belongs to a monophyletic group formed by a large polytomy that includes some genera and several groups of genera.

Atractosomus flavescens (Germar, 1839)

(Figs. 10, 61, 191, 212, 277, 337, 388, 389, 470, 497-499).

Atractodes flavescens Germar, 1839: 219; Candèze, 1891: 63 (cat.). Atractosomus flavescens; Candèze, 1859: 135; Schenkling, 1925: 86 (cat.); Blackwelder, 1944: 299 (cat.).

Length: 11.5-17.0 mm. General integument yellowish dorsally and brownish ventrally. Pubescence yellowish, moderately long and dense. Frons incompletely carinate, wider than long, slightly convex; punctuation moderately fine and dense. Nasal declivous, wider than long. Antennae (Fig. 10) with 11 antennomeres; in male 2 antennomeres longer than hind angles of pronotum; serrate in both sexes; scape shorter than eye; $2^{\text {nd }}$ antennomere globular, $3^{\text {rd }}$ triangular elongate, shorter than $4^{\text {th }}$; last narrowed at apex. Labrum (Fig. 61) semielliptical; anterior margin notched at middle; with long setae. Mandibles wide with one apical and one subapical tooth; penicillus formed by short setae disposed in whole mesal area; molar area well developed; dorsal region with carina and moderately long setae. Maxillae: galea with simple setae; last palpomere securiform. Labium: prementum with long setae in front of palpi; postmentum with two long setae and many moderately short. Pronotum (Fig. 212) wider than long, narrowed anteriad; flat; moderately convex anteriorly; lateral margins carinate; anterior slightly prominent at middle, almost straight; hind angles divergent and not carinate at middle; median basal tubercle indistinct; punctuation small and dense. Prosternal channel short. Prosternal spine (Fig. 191) widened apicad, with subapical tooth. Borders of mesosternal cavity raised and horizontal. Metacoxal plate normal, narrowed laterally; free margin with small lobe. Tibial spurs long; tarsomeres 1-3 lamellate beneath. Scutellum subtriangular and elongate. Elytra convex, narrowed on distal third; striae punctuated and grooved; interstices equal and flat.

Male. Tergite 8 wider than long, slightly narrowed to apex; anterior margin rounded; punctuate and setous laterally; clothed with microtrichiae. Sternite 8 (Fig. 277) translucent; anterior margin slightly prominent at middle; setae more concentrate near margins. Sternite 9: distal half gradually narrowed to apex; distal half punctuate and setous. Tergite 9 (Fig. 337) moderately notched at middle; punctuate with some setae near angles; tergite 10 longer than 9 with distal margin rounded; punctuate and setous on distal half. Aedeagus (Figs. 388,389 ) short and wide; basal piece slightly shorter than parameres; parameres fused ventrally; median lobe slightly narrowed to apex, slightly longer than parameres, constricted at apex; apex of parameres securiform.

Female. Tergite 8 subtriangular, punctuated with setae near margins. Sternite 8 (Fig. 470) with anterior margin rounded; punctuated with row of marginal setae on distal half; spiculum gastrale 3.27 times sternite length. Ovipositor with stylus; bursa copulatrix (Figs. 497-499) with 6 spiny areas; some areas with spines disposed star-like.

Material examined. BRAZIL. Rio de Janeiro: Serra Macahé, 1 ex. (MZSP); Teresópolis, 1 ex. (MNHN). São Paulo: Alto da Serra, 2 exs. (MZSP); (Estação Biológica de Paranapiacaba), 1 ex. (MZSP); Cajuru, 1 ex.(MZSP); Campos do Jordão, 1 ex. (MZSP); Paranapiacaba, 1 ex. (MZSP); Salesópolis (Estação Biológica de Boracéia), 3 exs. (MZSP); São Paulo, 1 ex. (MZSP); (Ipiranga), 2 exs. (MZSP); (Jabaquara), 1 ex. (MZSP); Serra da Cantareira, 1 ex. (MZSP). Santa Catarina: Nova Teutônia, 3 exs. (MZSP); Rio Vermelho, 7 exs. (MZSP).

\section{Blauta LeConte, 1853}

Blauta LeConte, 1853: 472; Candèze, 1859: 416, 489; 1891: 94 (cat.); Schwarz, 1906: 110, 121; Schenkling, 1925: 163 (cat.); Brown, 1936: 251; Casari, 2005: 448.

Aphanobius Eschscholtz, 1829: 33.

Type-species: Ampedus cribrarius Germar, 1844, by monotypy.

Leconte (1853) erected the genus Blauta to include $B$. cauta. Candèze (1859) transferred Ampedus cribarius Germar, 1844 to Blauta and synonymized B. cauta LeConte, 1853 under B. cribraria.

Schenkling (1925) included Blauta, monotypical, in the subfamily Elaterinae.

Brown (1936) described Blauta falli.

Stibick (1979) included the genus in Dicrepidiini. Casari (2005) presented a revision of the genus Blauta.

The genus Blauta is formed by 2 species: $B$. cribaria (Germar, 1844) and B. falli Brown, 1936. It is recorded from United States (North Carolina, Mississipi, Alabama, Georgia, South Carolina, Florida).

Blauta cribraria is characterized by synapomorphies, 51(0) lamella of protarsomere 4 present, 52(0) lamella of mesotarsomere 4 present and 53 (0) lamella of metatarsomere 4 present, and by homoplasies, 13(3) antennomere 3 of male elongate, short, 18(3) labrum subrectangular, 19(4) anterior margin of labrum straight, 21(2) mesal area of mandibles with one apical and one subapical tooth distant from apex, 25(0) setae of galea simple, 27(1) last palpomere slightly widened apicad, 28(2) pronotum as long as wide, 34(1) prosternal spine with rounded apex and 40(0) tibial spurs short. It belongs to a monophyletic group formed by a large polytomy that includes some genera and several groups of genera.

Blauta cribraria (Germar, 1844)

(Figs. 11, 62, 111, 161, 177, 254, 278, 314, 319, 338, 390, $391,471,500)$.

Ampedus cribarius Germar, 1844: 178.

Blauta cribraria; Candèze, 1859: 490; Schenkling, 1925: 163 (cat.); Casari 2005: 450 . 


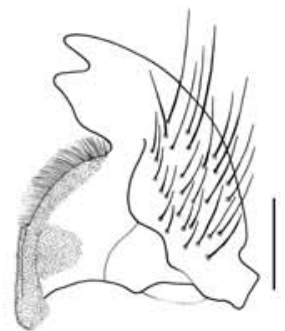

101

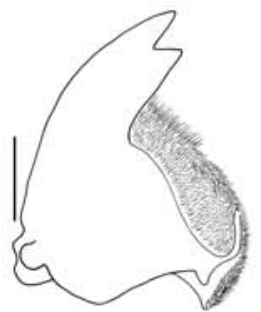

105

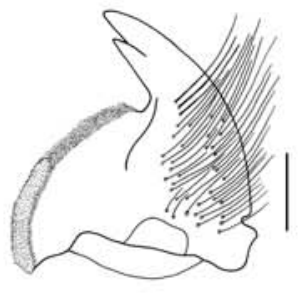

102

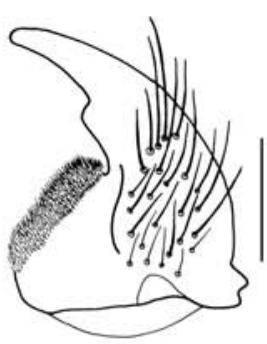

103

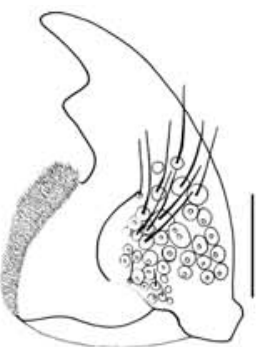

104

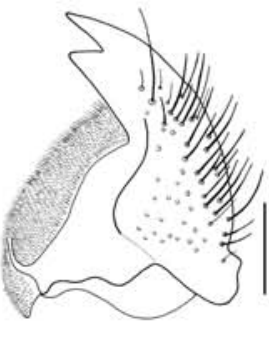

106

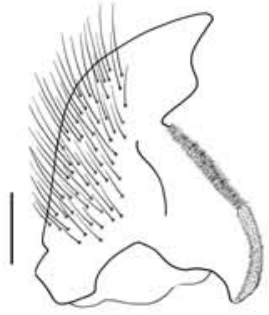

110

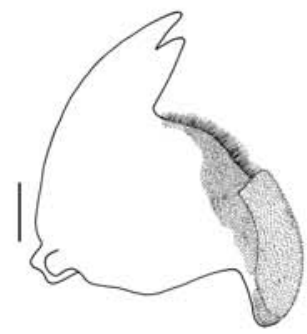

114

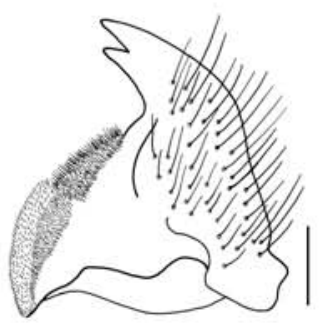

118

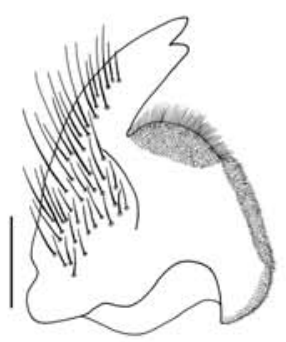

107

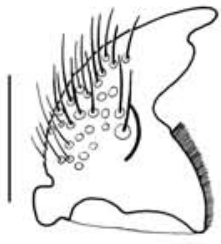

111

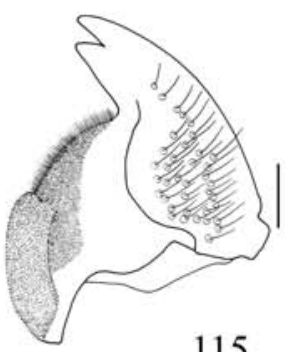

115

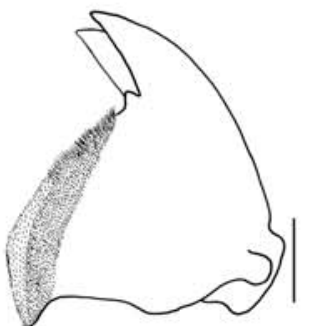

119

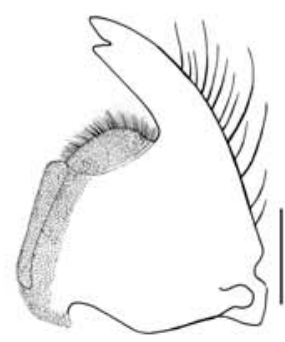

108

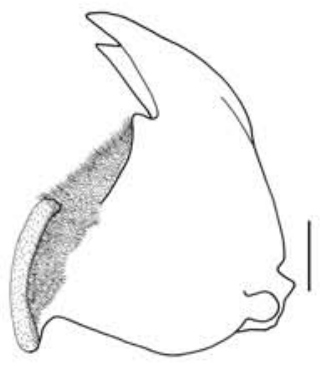

117

Figs. 101-120. Mandible: 101, Achrestus flavocinctus (D); 102, Achrestus venustus (D); 103, Adiaphorus gracilis (D); 104, Adiaphorus ponticerianus (D); 105, 106, Ampedus sanguineus (V, D); 107, 108, Anchastus digittatus (D, V); 109, Anoplischius bicarinatus (D); 110, Anoplischius haematopus (D); 111, Blauta cribraria (D); 112, 113, Calopsephus apicalis (D, V); 114, 115, Catalamprus angustus (V, D); 116, 117, Crepidius flabellifer (D, V); 118, 119, Crepidius resectus (D, V); 120, Ctenicera silvatica (D). Bars $=2 \mathrm{~mm}$. 
Length: 9-16 mm. Frons carinate, longer than wide; anterior margin rounded and surpassing nasal; convex. Nasal wider than long. Antennae (Fig. 11) with 11 antennomeres; in male 2.2 antennomeres longer than hind angles of pronotum; serrate in both sexes; scape shorter than eye; $2^{\text {nd }}$ antennomere globular, $3^{\text {rd }}$ elongate, short, shorter than $4^{\text {th }}$; last narrowed at apex. Labrum (Fig. 62) subrectangular with fore angles rounded, with long setae. Mandibles (Fig. 111) robust with one apical and one subapical tooth; penicillus formed by short setae disposed in whole mesal area; dorsal region with carina and moderately long setae. Maxillae (Fig. 161): galea with simple setae; last palpomere slightly widened at apex. Labium (Fig. 177): prementum with long setae in front of palpi; postmentum with two long setae and many moderately short. Pronotum longer than wide, narrowed anteriad; strongly convex; lateral margins incompletely carinate; anterior margin almost straight; hind angles slightly divergent and carinate; median basal tubercle transverse and flattened; punctuation moderately coarse and dense. Prosternal channel present. Prosternal spine with apex rounded. Borders of mesosternal cavity narrow between mesocoxae and declivous. Metacoxal plate (Fig. 254) strongly narrowed laterally; free margin with tooth near middle. Tibial spurs present; tarsomeres 1-4 lamellate beneath.

Male. Tergite 8 (Fig. 314) wider than long, with distal margin rounded; translucent in a narrow basal area; partially clothed with moderately long setae; clothed with microtrichiae. Sternite 8 (Fig. 278) band-like with fore angles rounded; translucent except a narrow transverse basal sclerite and 3 rounded and irregular bands near distal margin; setae more concentrate near angles. Sternite 9 (Fig. 319): distal half gradually narrowed to apex and setous. Tergite 9 (Fig. 338) strongly notched at middle, V-shaped; punctuate with setae near lateral margins; tergite 10 slightly longer than 9 , punctuate near base and setous on distal 2/3. Aedeagus (Figs. 390, 391): basal piece shorter than parameres; parameres fused ventrally; median lobe slightly longer than parameres, wider near base, with constricted apex; apex of parameres securiform.

Female. Sternite 8 (Fig. 471) elongate, narrowed at apex; setous; spiculum gastrale 3.25 times sternite length. Ovipositor with stylus; bursa copulatrix (Fig. 500) with 6 spiny areas; some areas with spines disposed star-like.

Material examined. UNITED STATES OF AMERICA. North Carolina: Moore Co., Southern Pines, 1 M (FSCA). South Carolina: Anderson and Pickens Cos., Clemson College, 1 M (MZSP). Mississipi: Forrest Co., Hattiesburg, 2 M (FSCA), Camp Shelby, nr. Hattiesburg, 1 M (MZSP). Alabama: Mobile Co., Mobile, 3 M, 1 F (FSCA). Georgia: Lowndes Co., 3 M (FSCA), 1 M (MZSP). Florida: Alachua Co., 1 M (FSCA), Gainesville, 3 M (FSCA), Pine Hills Estates, Gainesville, 1 M (FSCA); Columbia Co., Lake City, 1 M (FSCA); Escambia Co., Pensacola, 1 M, 1 F (FSCA); Indian River Co., 1 M (FSCA); Leon Co., Tall Timbers, 1 M (FSCA); Marion Co., Ocala, 1 F (FSCA); Osceola Co., 1 M (FSCA); Putman Co., Weems Property, Red Water Lake, 1 M (FSCA).

Calopsephus Basilewsky, 1958

Calopsephus Basilewsky, 1958: 472; Girard, 2003a: 461.

Type-species: Psephus apicalis Schwarz, 1903, by monotypy.
Basilewsky (1958) erected Calopsephus to Rhinopsephus apicalis (Schwarz, 1903). He also considered Ischiodontus melanoxanthoides Fleutiaux, 1906 as synonym of C. apicalis.

Cobos (1970) recorded C. apicalis from Republic of Congo [Congo-Brazzaville].

Girard (2003a) commented the presence of antennomeres with smooth longitudinal carina and strong sexual dimorfism in this genus. He recorded C. apicalis to Nimba.

The genus Calopsephus, monotypical, is recorded from Africa: Mount Nimba (borders of Guinea, Liberia, Ivory Coast), Ivory Coast, Nigeria, Cameroon, Central African Republic, Gabon, Congo, Democratic Republic of Congo.

Calopsephus apicalis is characterized by a synapomorphy, 24(1) galea brush-like wide and by homoplasies, 0(2) frons as wide as long, 9(2) antennae of female subserrate and 18(1) labrum semicircular. It belongs to a tricotomy together with Catalamprus angustus and Rhinopsephus apicalis.

Calopsephus apicalis (Schwarz, 1903)

(Figs. 12, 63, 112, 113, 162, 178, 213, 255, 279, 339, 392, 393, 501).

Psephus apicalis Schwarz, 1903: 48

Rhinopsephus apicalis; Schwarz, 1906: 82; Schenkling, 1925: 98 (cat.). Ischiodontus melanoxanthoides Fleutiaux, 1906; Basilewski, 1958: 472 (syn.).

Length: 8-10 mm. General integument dark-brown; pronotum yellow or brownish-yellow with longitudinal median band dark-brown, narrowed basad; hypomera bordered by narrow yellow band; elytra yellow with distal third dark-brown. Pubescence long, moderately thick, accompanying integument color. Frons carinate, as wide as long, wider anteriorly; convex and very prominent anteriorly; punctuation moderately coarse and dense. Nasal wider than long, with two longitudinal carina. Antennae (Fig. 12) with 11 antennomeres; in male 2.5 antennomeres longer than hind angles of pronotum; serrate in male, slightly serrate in female; scape shorter than eye; $2^{\text {nd }}$ antennomere globular, $3^{\text {rd }}$ triangular, shorter than $4^{\text {th }}$; last narrowed at apex; antennomeres 3-11 with longitudinal carina. Labrum (Fig. 63) semicircular, with long setae. Mandibles (Figs. $112,113)$ robust with one apical and one subapical tooth; penicillus formed by short setae disposed in whole mesal area; molar area well developed; dorsal region with carina and moderately long setae. Maxillae (Fig. 162): galea brush-like wide with spatulate setae; last palpomere securiform. Labium (Fig. 178): prementum with long setae in front of palpi; postmentum with two long setae and many moderately short [marked by punctures]. Pronotum (Fig. 213) wider than long, narrowed anteriad; strongly convex; convexity decreasing basad; lateral margins carinate; anterior margin straight; hind angles backwardly directed and carinate; median basal tubercle flat; punctuation moderately coarse and dense. Prosternal channel short. Prosternal spine with bilobed apex. Borders of mesosternal cavity declivous. Metacoxal plate (Fig. 255) slightly narrowed laterally; free margin with well developed tooth. Tibial spurs absent; tarsomeres 2-3 lamellate beneath. 


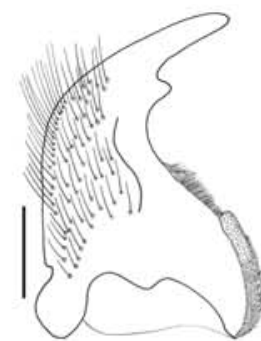

121
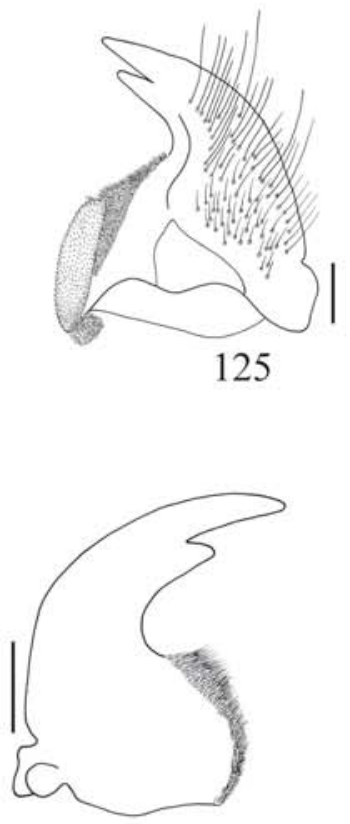

129

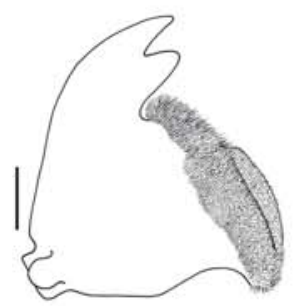

133

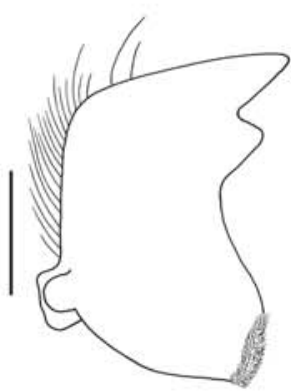

137

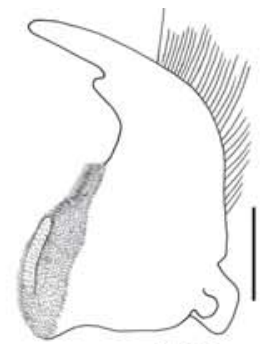

122
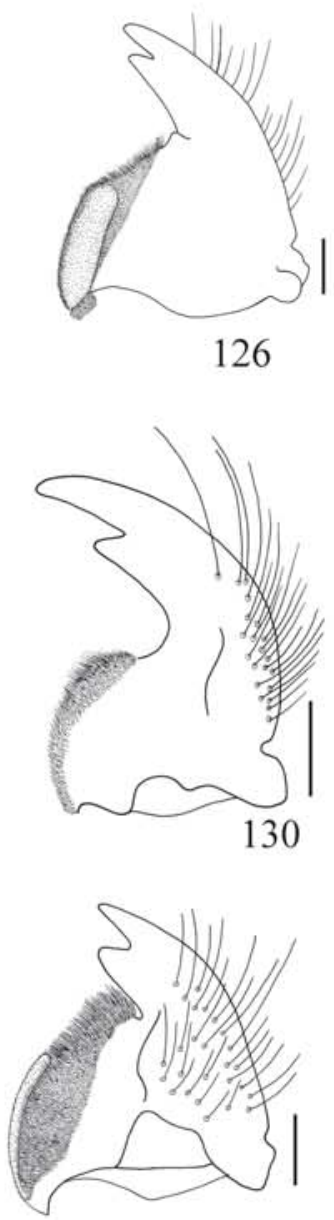

134

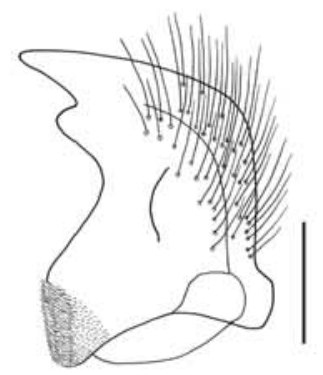

138

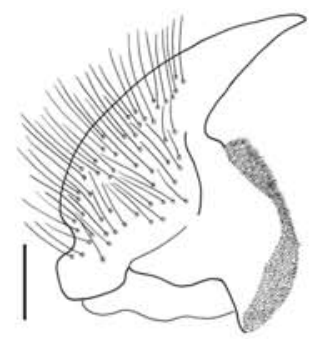

123
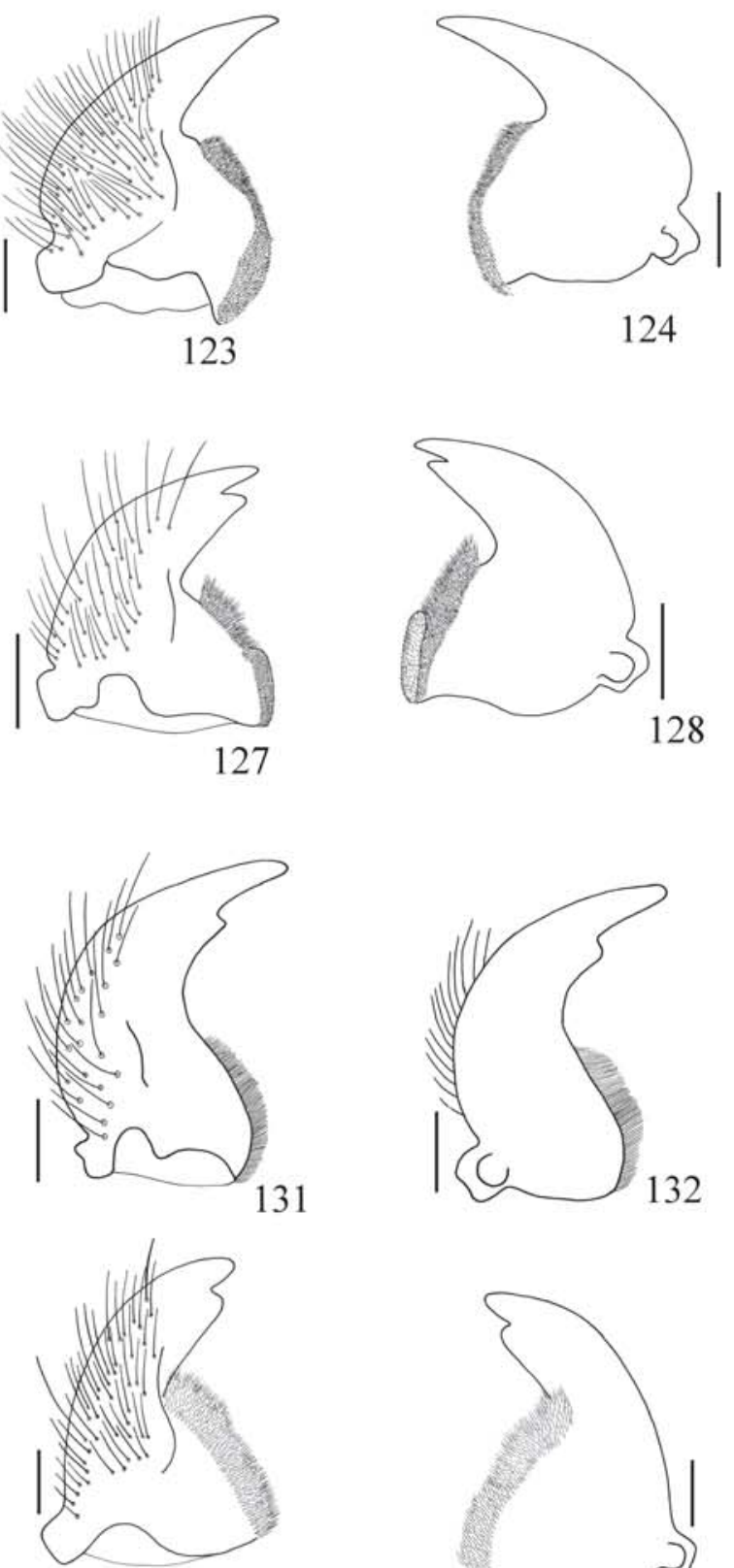

135
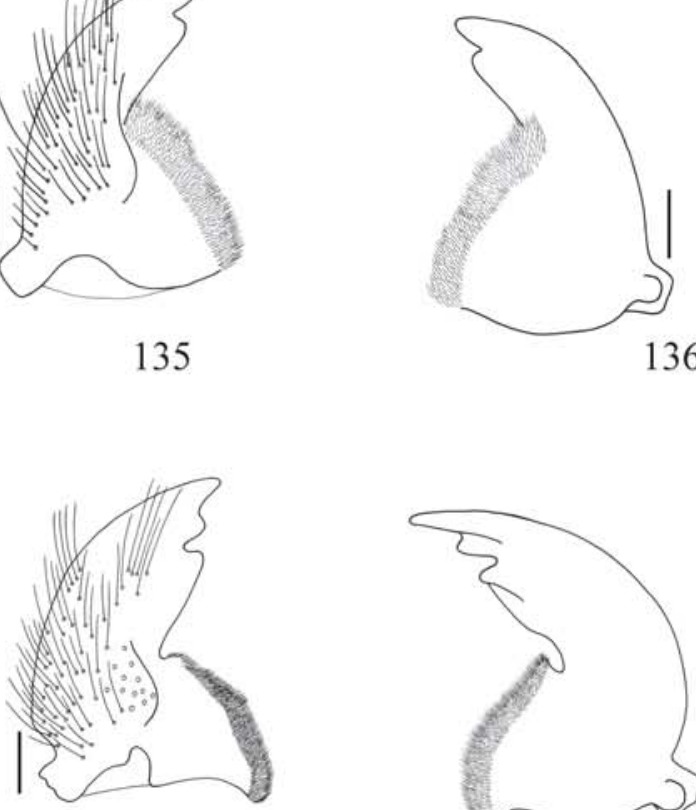

139

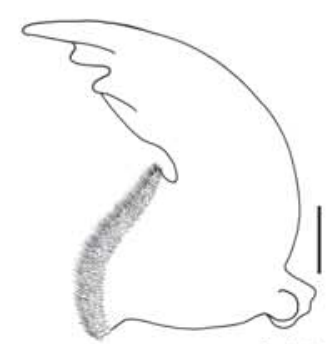

140

Figs. 121-140. Mandible: 121, 122, Cyathodera longicornis (D, V); 123, 124, Dayakus angularis (D, V); 125, 126, Dicrepidius ramicornis (D, V); 127, 128, Dipropus schwarzi (D, V); 129, 130, Heterocrepidius gilvellus (V, D); 131, 132, Heterocrepidius ventralis (D, V); 133, 134, Lampropsephus cyaneus (V, D); 135, 136, Melanotus spernendus (D, V); 137, 138, Olophoeus gibbus (V, D); 139, 140, Ovipalpus pubescens (D, V). Bars $=2 \mathrm{~mm}$. 
Scutellum elongate with posterior angles rounded; posterior margin notched or not at middle. Elytra slightly convex, slightly narrowed apicad; striae punctuate and grooved; interstices convex and unequal.

Male. Tergite 8 as wide as long, with anterior margin rounded; punctuate and marginate by setae; clothed with microtrichiae. Sternite 8 (Fig. 279) translucent except two lateral longitudinal bands; anterior margin narrowed and slightly notched at middle; setae more concentrate laterally. Sternite 9: distal half gradually narrowed to apex; distal third setous. Tergite 9 (Fig. 339) strongly notched at middle, Vshaped; punctuate with some setae near angles; tergite 10 longer than 9 with some setae. Aedeagus (Figs. 392, 393): basal piece as long as parameres, prominent at base; parameres fused ventrally; median lobe slightly longer than parameres, strongly narrowed at middle and at apex; apex of parameres securiform.

Female. Tergite 8 elongate, narrowed on distal third; punctuated and setous. Sternite 8 elongate, narrowed on distal half; setous; spiculum gastrale 3.30 times sternite length. Ovipositor with stylus; bursa copulatrix (Fig. 501) with 5 spiny areas; some areas with spines disposed star-like.

Material examined. CENTRAL AFRICAN REPUBLIC. La Maboké, 12 exs. (MNHN). NIGERIA. Fakalé, 3 exs (MNHN). IVORY COAST. Bingerville, Test Cacaoyen, 1 ex. (MNHN); Ferkessédougou, 1 ex. (MNHN). CAMEROON. Akonolinga, 1 ex. (MNHN); Evindissi, 2 exs (MNHN); Fegmimbang, Test Cacao, 1 ex. (MNHN); Ngoumou, 1 ex. (MNHN); Nkobang, Test Cacao, 1 ex. (MNHN); Nkolmesseng, 1 ex. (MNHN); Ukolbisson, 1 ex. (MNHN). GABON. Mvoum, Montagne de Sable, 1 ex. (MNHN); Ogooué, N’Gomo, 1 ex. (MNHN); Oyem, 1 ex. (MNHN). CONGO. Mbila (Mts du Chaillu), 1 ex. (MNHN).

Catalamprus Basilewsky, 1958

Catalamprus Basilewsky, 1958: 374; Girard, 2003a:462.

Type-species: Pantolamprus angustus Fleutiaux, 1902, by original designation.

Basilewsky (1958) erected Catalamprus to segregate two species from Pantolamprus: P. angustatus and P. antennalis. He also presented a key to the two species.

Girard (2003a) commented the similarity of this genus with Pantolamprus, and recorded C. angustus to Nimba.

The genus Catalamprus is formed by 2 species: C. angustus (Fleutiaux, 1902) and C. antennalis (Fleutiaux, 1935). It is recorded from Central African Republic, Gabon and Democratic Republic of the Congo.

Catalamprus angustus is characterized by a synapomorphy, 24(2) galea transverse, and by homoplasies, 14(2) antennomere 3 as long as 4,25(4) setae of galea simple and spatulate, 35(2) borders of mesosternal cavity horizontal followed by declivous and 73(1) spines of bursa copulatrix disposed in irregularly way. It belongs to a tricotomy together with Calopsephus apicalis and Rhinopsephus apicalis.

Catalamprus angustus (Fleutiaux, 1902)

(Figs. 13, 64, 114, 115, 163, 192, 214, 256, 472, 502).
Pantolamprus angustus Fleutiaux, 1902:137; Schenkling, 1925: 74 (cat.). Catalamprus angustus; Basilewsky, 1958: 374.

Length: 11-15 mm. General integument brown or darkbrown; dorsal region darker and with blue metallic shine; antennae dark-brown; legs brownish. Pubescence black, long, fine and bristle. Frons carinate, wider than long, wider and prominent anteriorly, surpassing nasal; convex with a concavity near anterior margin; punctuation moderately coarse and sparse. Nasal wider than long. Antennae (Fig. 13) of female with 11 antennomeres; serrate; scape shorter than eye; $2^{\text {nd }}$ antennomere globular, $3^{\text {rd }}$ triangular, as long as $4^{\text {th }}$; last elliptical; antennomeres 3-8 with longitudinal carina. Labrum (Fig. 64) semielliptical, with long setae distributed in whole surface. Mandibles (Figs. 114, 115) robust with one apical and one subapical tooth; penicillus formed by short setae disposed in whole mesal area; molar area well developed; dorsal region with carina and moderately long setae. Maxillae (Fig. 163): galea wider than long, with a particular shape, bearing setae simple and long and setae spatulate; last palpomere widened to apex. Labium: prementum with long setae near middle, in front of palpi; postmentum with two long setae and several moderately short. Pronotum (Fig. 214) wider than long, narrowed anteriorly and near hind angles base; roundly convex; lateral margins carinate; anterior margin straight; hind angles long, slightly divergent and carinate; median basal tubercle flat; punctuation moderately coarse and sparse. Prosternal channel short. Prosternal spine (Fig. 192) widened to apex with subapical lobe. Borders of mesosternal cavity horizontal at basal third and vertical distally. Metacoxal plate (Fig. 256) strongly narrowed laterally; free margin with well developed tooth. Tibial spurs absent; tarsomeres 2-3 lamellate beneath. Scutellum elongate; distal half wider with margin rounded. Elytra convex, narrowed on distal fourth; striae coarsely punctuate; interstices unequal and flat.

Female. Tergite 8 elongate, subtriangular; punctuate and setous. Sternite 8 (Fig. 472) elongate, narrowed on distal half; partially setous; spiculum gastrale 4.15 times sternite length. Ovipositor with stylus; bursa copulatrix (Fig. 502) with spines and sclerotized plates of varied sizes and disposed in irregular way.

Material examined. CENTRAL AFRICAN REPUBLIC. La Maboké, 1ex. (MNHN). GABON. Oyem, 1 ex. (MNHN).

\section{Crepidius Candèze, 1859}

Crepidius Candèze, 1859: 9; 1891: 60 (cat.); Champion, 1895: 316; Schwarz, 1906: 59, 64; Schenkling, 1925: 76 (cat.); Blackwelder, 1944 : 297 (cat.); Golbach, 1994: 25.

Dicrepidius Erichson 1847: 77; Dejean, 1833: 96.

Heterocrepidius (pars) Lacordaire 1857: 170.

Type-species: Crepidius resectus Candèze, 1859, designated by Hyslop, 1921.

Candèze (1859) erected the genus Crepidius for seven new species, C. cuneiformis (Cayenne), C. emarginatus (Brazil), C. ophthalmicus (Brazil), C. pubescens (Brazil - RJ), C. 
208

Casari

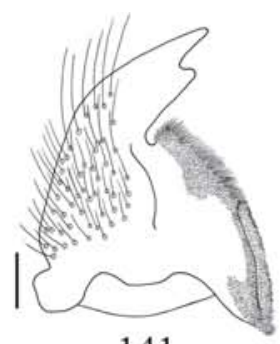

141

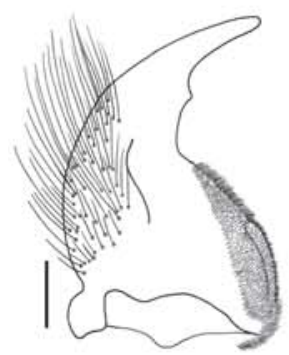

145

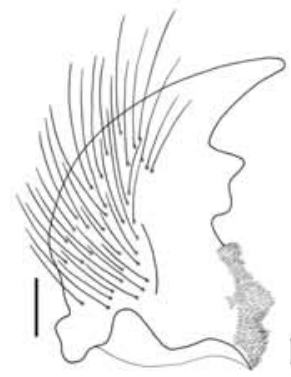

149

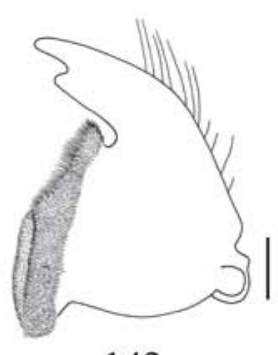

142

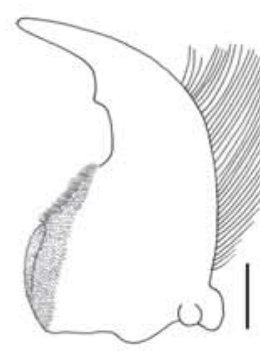

146
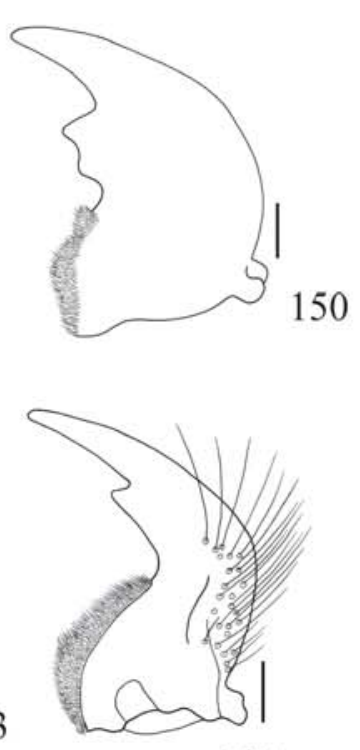

154

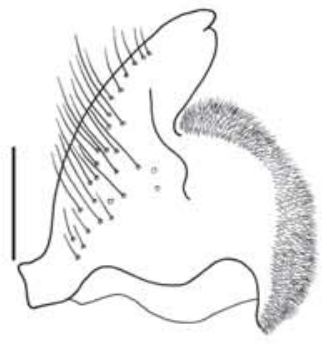

143
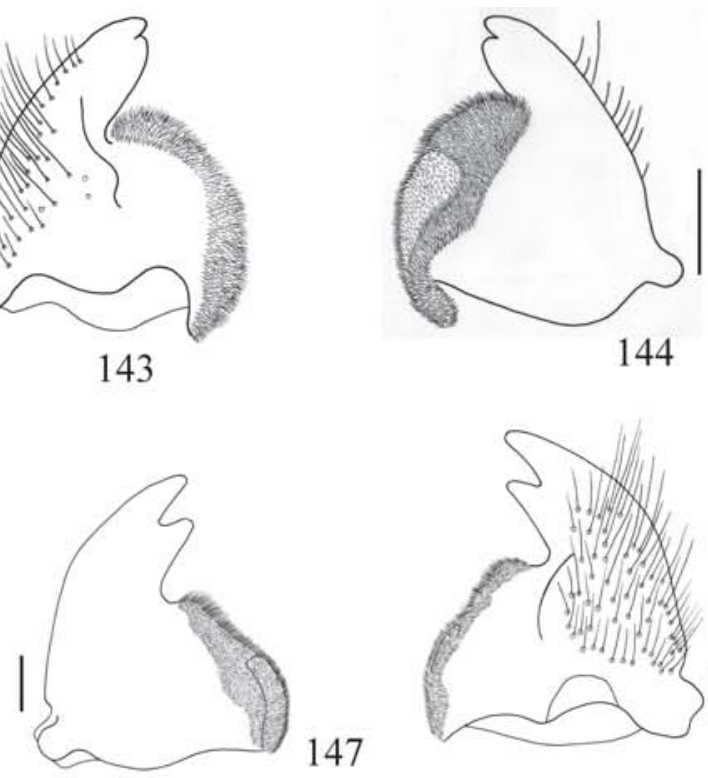

144

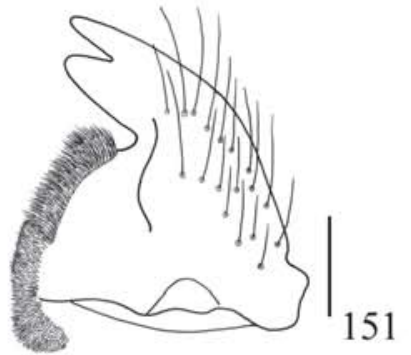

153
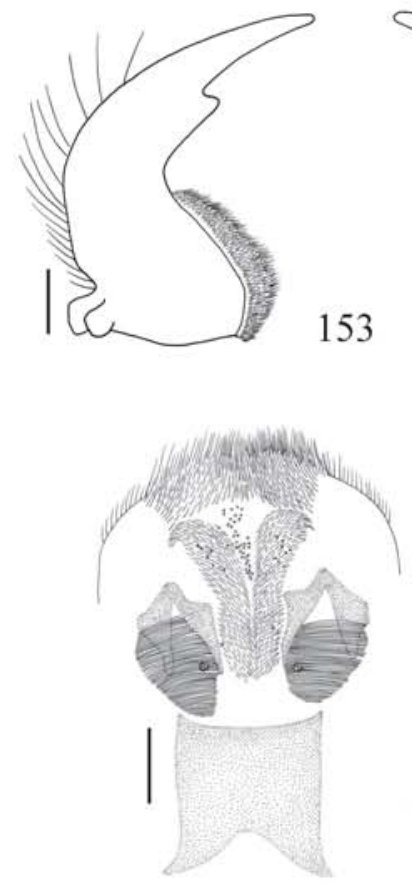

157

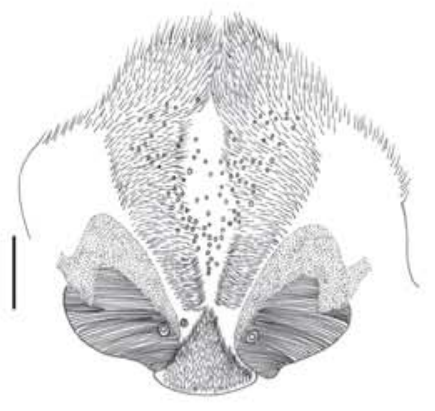

158
147
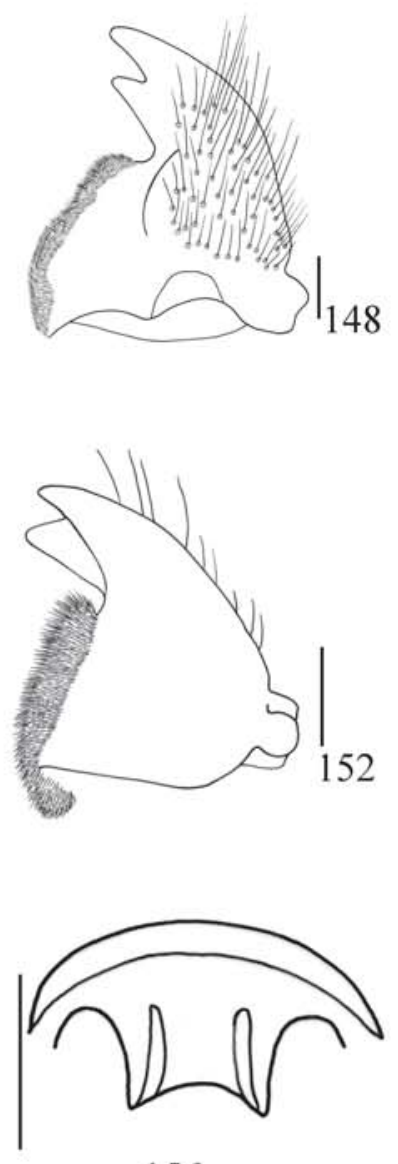

156

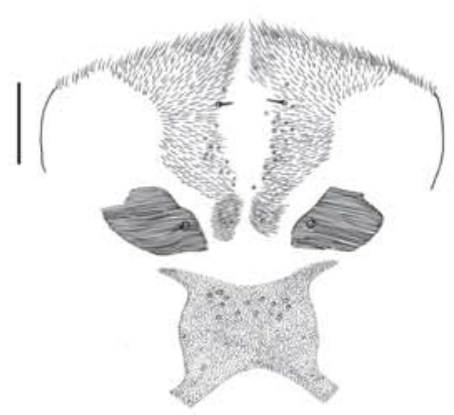

159

Figs. 141-159. Mandible: 141, 142, Pantolamprus perpulcher (D, V); 143, 144, Physorhinus xanthocephalus (D, V); 145, 146, Proloboderus crassipes (D, V); 147, 148, Propsephus beniensis (V, D); 149, 150, Pseudolophoeus guineensis (D, V); 151, 152, Spilus nitidus (D, V); 153, 154, Trielasmus varians (V, D). Nasal: 155, Dicrepidius ramicornis; 156, Rhinopsephus apicalis. Epipharynx: 157, Propsephus cavifrons; 158, Singhalenus gibbus; 159, Trielasmus varians. Bars $=2 \mathrm{~mm}$, except figs. $154,156=0.5 \mathrm{~mm}$ and fig. $162=1 \mathrm{~mm}$.

Revista Brasileira de Entomologia 52(2): 182-260, junho 2008 
resectus (Brazil), C. rhipiphorus (Guadaloupe) and $C$. saundersii (Bords de l'Amazone), and two removed from genus Dicrepidius, D. castaneus Blanchard, 1843 (Brazil, Uruguay, Bolivia) and D. flabellifer Erichson, 1847 (America Equatorial). He divided the genus into two groups according to shape of frons and only C. ophthalmicus was included into the first section.

Candèze (1891) catalogued 9 species to this genus.

Candèze (1900) described C. ornatus from Peru.

Schwarz (1906) included 15 species into the genus.

Schenkling (1925) and Blackwelder (1944) catalogued, besides the Candèze's species, also C. blepharipes Schwarz, 1900, C. cuneipennis Schwarz, 1906, C. flavipes Champion, 1897, C. ornatus Candèze, 1900, C. resplendidus Champion, 1895, totalizing 14 species.

The genus Crepidius is formed by 14 species: $C$. blepharipes Schwarz, 1900, C. castaneus Blanchard, 1843, C. cuneiformis Candèze, 1859, C. cuneipennis Schwarz, 1906, C. emarginatus Candèze, 1859, C. flabellifer (Erichson, 1847), C. flavipes Champion, 1897, C. ophthalmicus Candèze, 1859, C. ornatus Candèze, 1900, C. pubescens Candèze, 1859, C. replendens Champion, 1895, C. resectus Candèze, 1859, $C$. rhipiphorus Candèze, 1859 (= Ischiodontus convexus Felutiaux \& Sallé, 1890), C. saundersii Candèze, 1859. It is recorded from North America (Mexico), Central America (Guatemala, Nicaragua), Antilles (Guadeloupe, St Vicente), South America (French Guiana, Brazil, Ecuador, Peru, Bolivia, Argentina, Peru, Uruguay).

The Crepidius species included in this analysis form a monophyletic group. It is characterized by one homoplasy, 69(2) apex of sternite 8 of female widely rounded. It is the sister-group of Dicrepidius ramicornis.

Crepidius flabellifer (Erichson, 1847)

(Figs. 65, 116, 117, 193, 215, 257, 281, 320, 341, 396, 397, 474, 504).

Dicrepidius flabellifer Erichson, 1847: 77.

Crepidius flabellifer; Candèze, 1859: 82; Schenkling, 1925: 76 (cat.); Blackwelder, 1944: 297(cat.).

Length: 13-18 mm. General integument reddish-brown with lateral band on elytra and ususally on pronotum, dark-brown. Pubescence fine, long, yellowish, bristle and moderately dense. Frons carinate, longer than wide, flat with anterior concavity; anterior margin wider and prominent, surpassing nasal; punctuation moderately coarse and sparse. Nasal longer than wide. Antennae with 11 antennomeres; in male 3.2 antennomeres longer than hind angles of pronotum; flabellate in male, serrate in female; scape shorter than eye; $2^{\text {nd }}$ antennomere globular, $3^{\text {rd }}$ with lateral appendix, shorter than $4^{\text {th }}$, shorter in female; last with narrowed apex. Labrum (Fig. $65)$ subrectangular with anterior angles rounded; with long setae. Mandibles (Figs. 116, 117) robust with one apical and one subapical tooth; penicillus formed by short setae disposed in whole mesal area; molar area well developed; ventral region with small tooth at base of penicillus; dorsal region with carina and moderately long setae. Maxillae: galea with spatulate setae; last palpomere securiform. Labium: prementum with long setae in front of palpi; postmentum with two long setae and many moderately short. Pronotum (Fig. 215) wider than long, slightly narrowed anteriad; slightly convex; lateral margins straight and incompletely carinate; anterior margin straight; hind angles long, backwardly directed and carinate; median basal tubercle flat; punctuation moderately coarse and dense, except transverse basal band, sparse. Prosternal channel absent. Prosternal spine (Fig. 193) with narrowed apex and subapical lobe. Borders of mesosternal cavity declivous. Metacoxal plate (Fig. 257) strongly narrowed laterally; free margin with well developed tooth. Tibial spurs short; tarsomeres 1-3 lamellate beneath. Scutellum elongate with posterior margin narrower and rounded. Elytra slightly convex, narrowed apicad; striae marked by coarse punctures; interstices equal and flat.

Male. Tergite 8 as long as wide, slightly narrowed to apex; punctuate and marginate by setae; clothed with microtrichiae. Sternite 8 (Fig. 281) translucent at middle and laterally on basal half; anterior margin narrower and strongly notched at middle; setae more concentrate near anterior margin. Sternite 9 (Fig. 320): distal half gradually narrowed to apex; apex very narrowed, triangular; distal third setous. Tergite 9 (Fig. 341) moderately notched at middle; punctuate with setae near anterior angles; tergite 10 slightly longer than 9 , punctuate and setous lateromedially. Aedeagus (Figs. 396, 397): basal piece much longer than parameres; parameres fused ventrally, moderately longer than median lobe; median lobe slightly narrowed near middle and constricted at apex; apex of parameres narrow and securiform.

Female. Tergite 8 elongate, subtriangular and setous. Sternite 8 (Fig. 474) elongate, slightly narrowed to apex; setous; spiculum gastrale 6.30 times sternite length. Ovipositor with stylus; bursa copulatrix (Fig. 504) with 4 small spiny areas, disposed star-like.

Material examined. BRAZIL. Rio de Janeiro: Itatiaia, 1 ex. (MZSP). São Paulo: Botucatu, 12 exs. (MZSP); São Bernardo, 1 ex. (MZSP); São Paulo, 1 ex. (MZSP); (Ipiranga), 1 ex. (MZSP). Paraná: Ponta Grossa, 1 ex. (MZSP); Rolândia, 1 ex. (MZSP). Santa Catarina: Rio Vermelho, 2 exs. (MZSP).

Crepidius resectus Candèze, 1859

(Figs. 66, 118, 119, 258, 321, 342, 398, 399, 475, 505).

Crepidius resectus Candèze, 1859: 84; Schenkling, 1925: 76 (cat.); Blackwelder, 1944: 297 (cat.).

Length: 13-16 mm. General integument reddish-brown clear; legs slightly clear. Pubescence fine, long, yellowish and bristle. Frons carinate, longer than wide, flat; wider and prominent anteriorly, surpassing nasal; punctuation moderately coarse and sparse. Nasal longer than wide. Antennae with 11 antennomeres; in male 3.7 antennomeres longer than hind angles of pronotum; flabellate in male, serrate in female; scape shorter than eye; $2^{\text {nd }}$ antennomere globular, $3^{\text {rd }}$ triangular, shorter than $4^{\text {th }}$, with lateroposterior appendix, shorter in female; last with narrowed apex. Labrum (Fig. 66) semielliptical, 


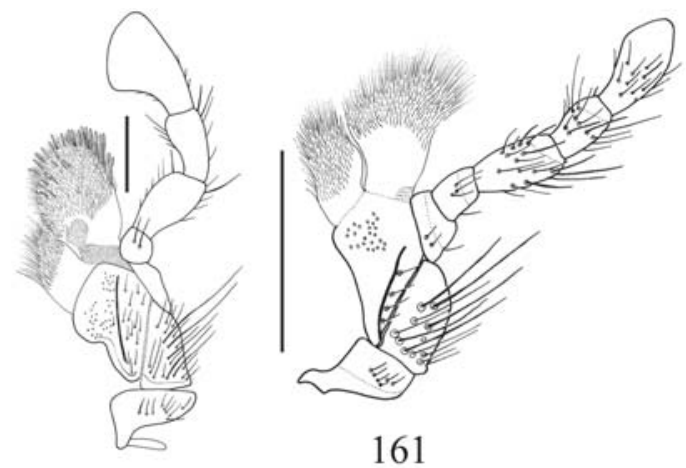

160

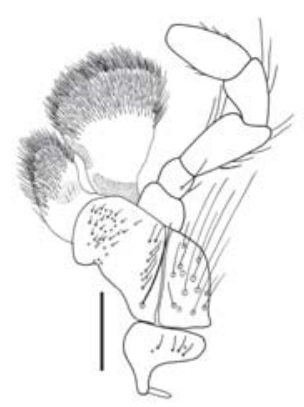

165

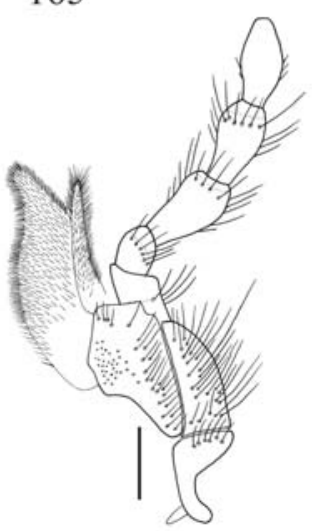

169

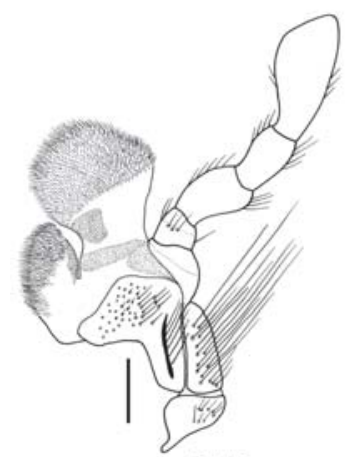

173

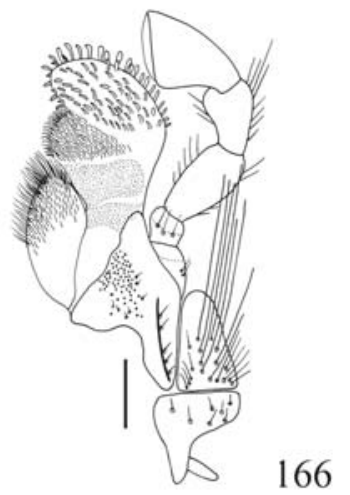

166

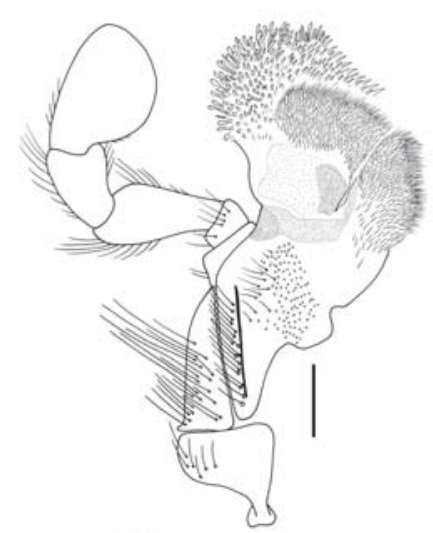

170

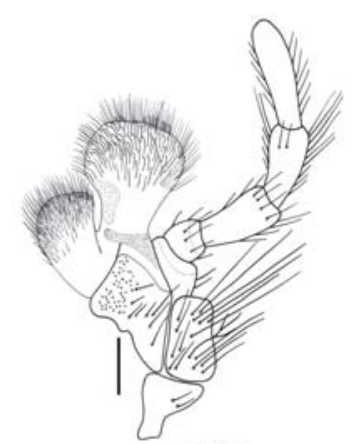

174

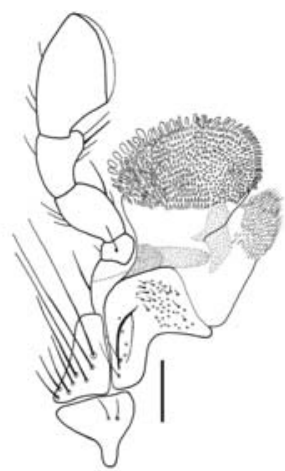

162

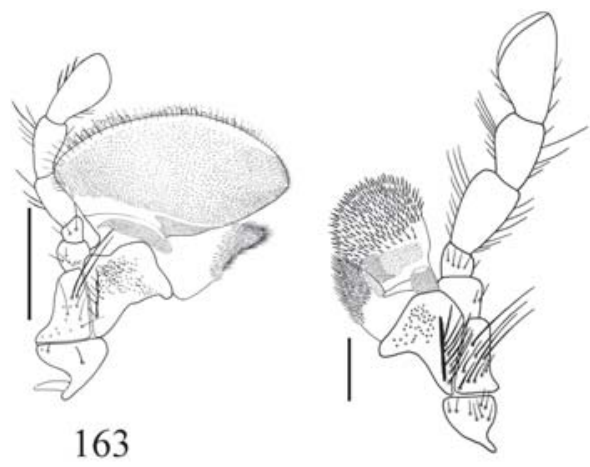

164

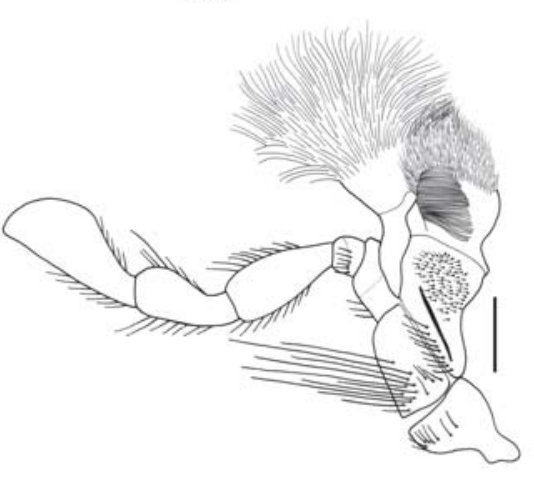

167

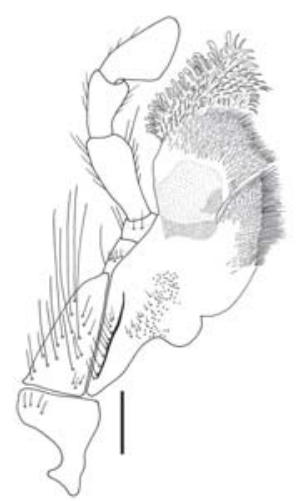

171

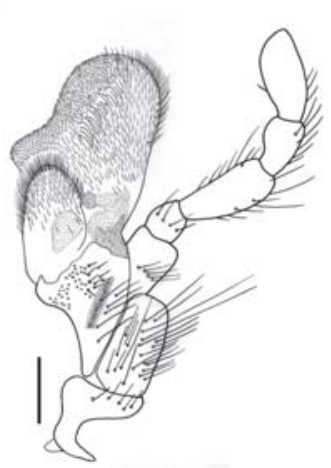

175

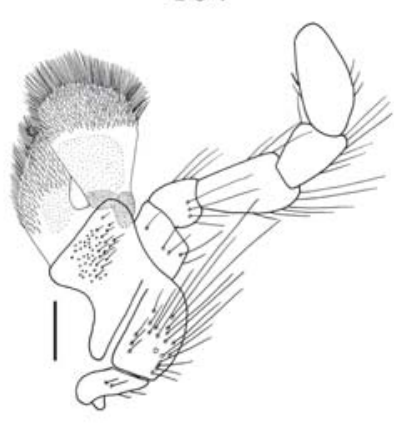

168

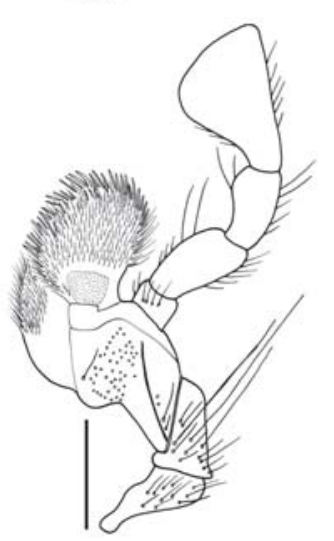

172

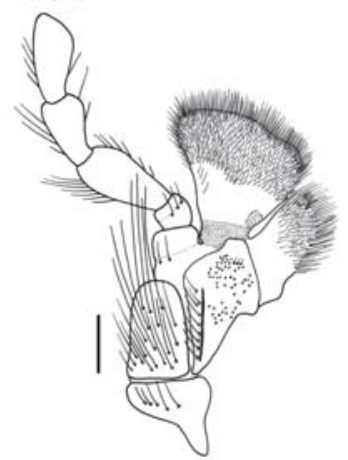

176

Figs. 160-176. Maxilla: 160, Ampedus sanguineus; 161, Blauta cribraria; 162, Calopsephus apicalis; 163, Catalamprus angustus; 164, Dayakus angularis; 165, Heterocrepidius gilvellus; 166, Lampropsephus cyaneus; 167, Melanotus spernendus; 168, Olophoeus gibbus; 169, Ovipalpus pubescens; 170, Pantolamprus mirabilis; 171, Pantolamprus perpulcher; 172, Physorhinus xanthocephalus; 173, Proloboderus crassipes; 174, Pseudolophoeus guineensis; 175, Sphenomerus antennalis; 176, Sphenomerus brunneus. Bars $=1 \mathrm{~mm}$, except fig. $161=5 \mathrm{~mm}$. 
with long setae. Mandibles (Figs. 118, 119) robust with one apical and one subapical tooth; penicillus formed by short setae disposed in whole mesal area; molar area well developed; left mandible with small ventral tooth at base of penicillus; dorsal region with carina and moderately long setae. Maxillae: galea with spatulate setae; last palpomere securiform. Labium: prementum with long setae in front of palpi; postmentum with two long setae and many moderately short [marked by punctures]. Pronotum wider than long, slightly narrowed anteriad; slightly convex; lateral margins incompletely carinate; anterior margin straight; hind angles backwardly directed and carinate; median basal tubercle flat; punctuation moderately coarse and sparse. Prosternal channel absent. Prosternal spine with narrowed apex and subapical lobe. Borders of mesosternal cavity declivous. Metacoxal plate (Fig. 258) strongly narrowed laterally; free margin with well developed tooth. Tibial spurs short; tarsomeres 1-3 lamellate beneath. Scutellum elongate with posterior margin narrower and rounded. Elytra slightly convex, narrowed apicad; striae marked by coarse punctuation; interstices equal and flat.

Male. Tergite 8 elongate, subtriangular, punctuate and marginate by setae; clothed with microtrichiae. Sternite 8 translucent at middle and laterally on basal half; anterior margin narrower and slightly notched at middle; setae more concentrate near margins. Sternite 9 (Fig. 321): distal half gradually narrowed to apex; distal third setous. Tergite 9 (Fig. 342) strongly notched at middle, V-shaped; punctuate; tergite 10 shorter than 9 and punctuate. Aedeagus (Figs. 398, 399): basal piece much longer than parameres; parameres fused ventrally; median lobe almost straight, narrowed at apex and slightly longer than parameres; apex of parameres narrow and securiform.

Female. Tergite 8 elongate, subtriangular and setous. Sternite 8 (Fig. 475) elongate, slightly narrowed on distal half; setous; spiculum gastrale 4.70 times sternite length. Ovipositor with stylus; bursa copulatrix (Fig. 505) with 4 small spiny areas.

Material examined. BRAZIL. São Paulo: Botucatu, 2 exs. (MZSP).

Cyathodera Blanchard, 1843

Cyathodera Blanchard, 1843: 130; Candèze, 1891: 57 (cat.); Anoplischius (Cyathodera); Schenkling, 1925: 81 (cat.).

Anoplischius; Candèze, 1859: 76.

Type-species: Cyathodera longicornis Blanchard, 1843, by monotypy.

Blanchard (1843) erected the genus Cyathodera to C.longicornis, based on one specimen collected "près de SantaAna, dans la province de Chiquitos".

Candèze (1859) synonymyzed the genus under Anoplischius; the species of Cyathodera corresponds to section IV of Anoplischius.

Candèze (1891) raised it to genus, and catalogued two species: C. lanugicollis (Candèze, 1859) and C. longicornis Blanchard, 1843.
Champion (1895) followed Candèze, 1859.

Schwarz (1906), Schenkling (1925) and Blackwelder (1944) considered Cyathodera a subgenus of Anoplischius.

Costa (1968) described Anoplischius (Cyathodera) auripilosus and stated that after studying some characters of some species from two subgenera, it appears that they are two different genera.

Golbach (1994) considered Cyathodera as a valid genus.

The genus Cyathodera is formed by 4 species: $C$. auripilosus Costa, 1968, C. lanugicollis (Candèze, 1859), C. longicornis Blanchard, 1843 and C. spinipennis Schwarz, 1902. It is recorded from Central America (Nicaragua, Panama) and South America (Guyana, Suriname, French Guiana, Brazil, Ecuador, Peru).

The Cyathodera species included in this analysis form a monophyletic group. It is characterized by synapomorphies, 17(0) longitudinal smooth band on antennae present and 66(3) median lobe twice parameres lenght, and by homoplasies, $7(2)$ nasal as wide as long, 40(2) tibial spurs very long and 62(2) basal piece longer than parameres. It is the sister-group of (Trielasmus varians (Paraloboderus glaber ((Loboederus appendiculatus $)$ (Proloboderus crassipes)))).

\section{Cyathodera auripilosus Costa, 1968}

Anoplischius (Cyathodera) auripilosus Costa, 1968:161.

Length: 14-17 mm. General integument reddish-brown; antennae brown. Pubescence ferruginous, very long and dense; longer on lateral margins of pronotum and leytra. Frons carinate, longer than wide, concave medioanteriorly; anterior margin rounded, prominent surpassing nasal; punctuation moderately coarse and dense, sparser at middle. Nasal as wide as long. Antennae with 11 antennomeres; in male 3.5 antennomeres longer than hind angles of pronotum; subserrate in both sexes; scape shorter than eye; $2^{\text {nd }}$ antennomere globular, $3^{\text {rd }}$ triangular, same shape and shorter than $4^{\text {th }}$, last narrowed at apex; antennomeres with longitudinal smooth band. Pronotum wider than long, slight- and irregularly convex, narrowed anteriorly; with longitudinal median grooves; anterior margin prominent at middle; hind angles long, carinate, backwardly directed; median basal tubercle indistinct; punctuation small and dense. Prosternal channel long. Prosternal spine with subapical lobe. Borders of mesosternal cavity narrow and declivous. Metacoxal plate strongly narrowed laterally; free margin straight. Tibial spurs very long; tarsomeres 1-3 lamellate beneath. Scutellum triangular elongate. Elytra convex, slightly narrowed apicad with sutural small spine; striae coarsely punctuate; interstices equal and flat, convex near base.

Male. Sternite 9: distal third abruptly narrowed to apex; setous near margins and at apex. Tergite 9 slightly notched at middle; punctuate; tergite 10 longer than 9. Aedeagus elongate; basal piece longer than parameres; parameres fused ventrally; median lobe very long, straight, constricted at apex; subapical region of parameres slitted. 


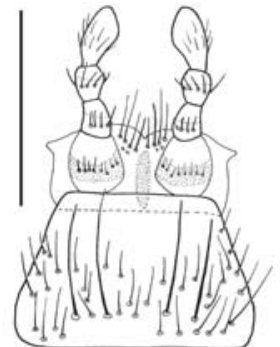

177

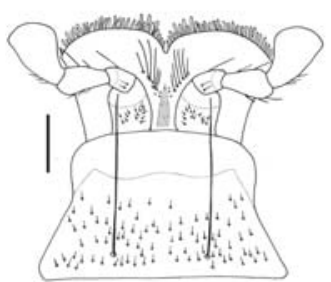

181

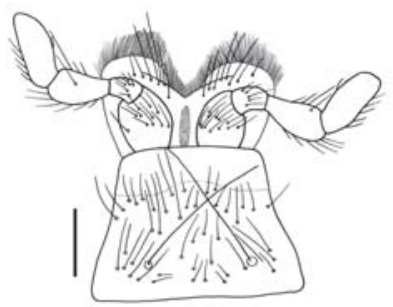

185

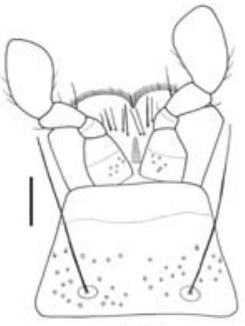

178

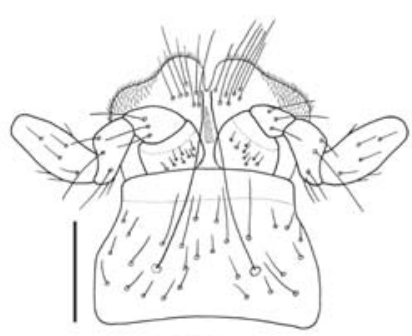

179
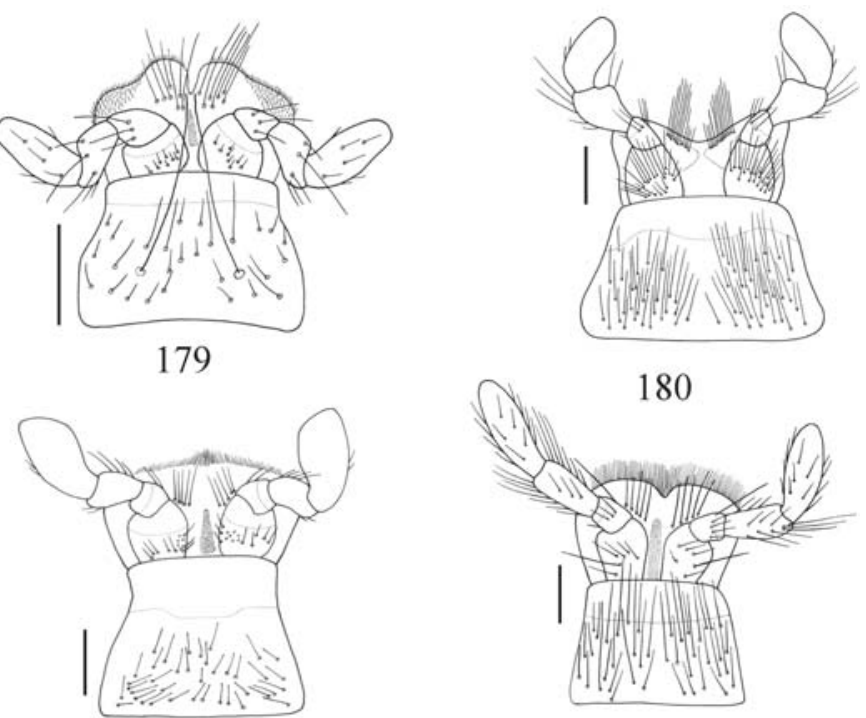

183
180

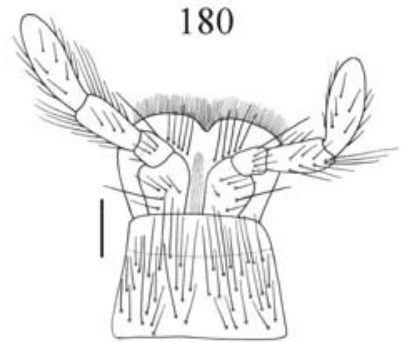

184

182
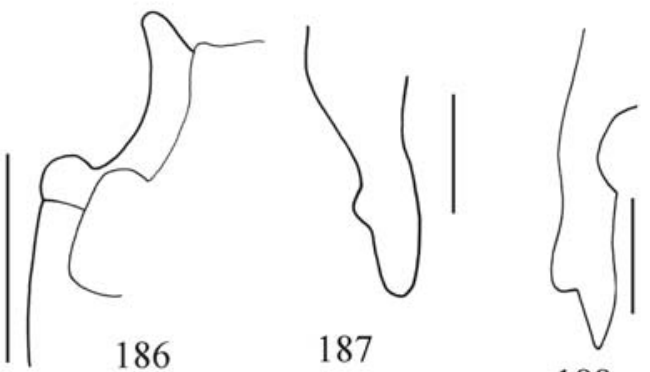

188

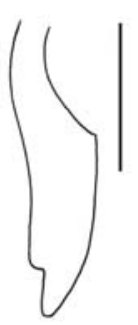

189

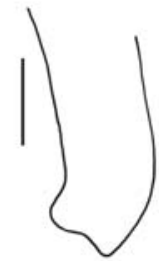

190
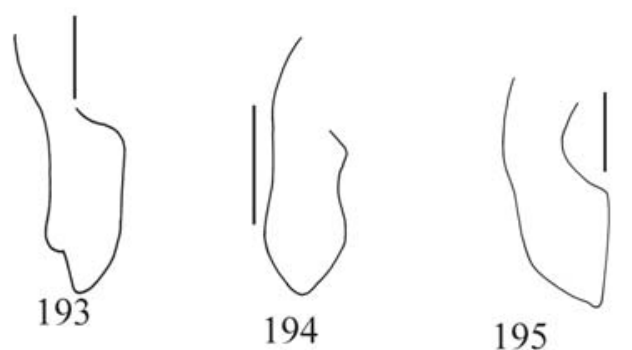

195
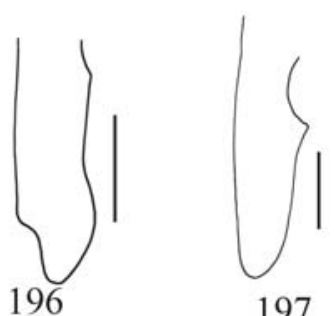

197

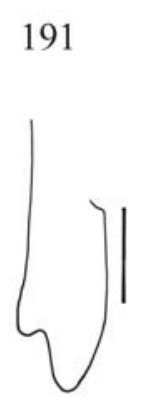

198

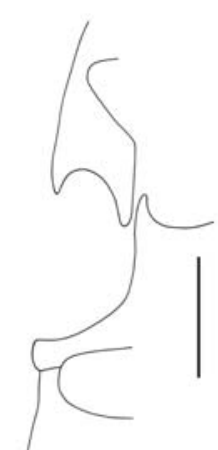

199

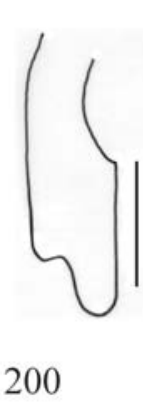

200

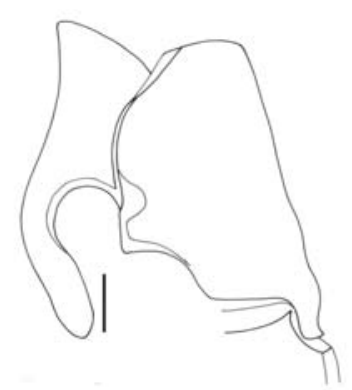

201

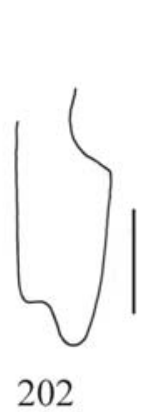

202

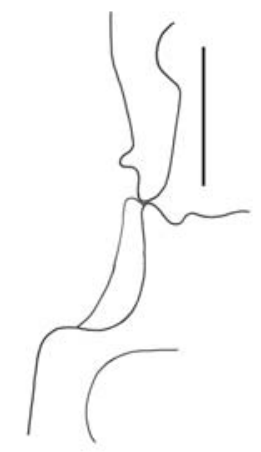

203

Figs. 177-203. Labium: 177, Blauta cribraria; 178, Calopsephus apicalis; 179, Heterocrepidius gilvellus; 180, Ovipalpus pubescens; 181, Pantolamprus perpulcher; 182, Physorhinus xanthocephalus; 183, Proloboderus crassipes; 184, Pseudolophoeus guineensis; 185, Sphenomerus antennalis. Borders of mesosternal cavity: 186, Achrestus flavocinctus. Prosternal spine: 187, Achrestus flavocinctus; 188, Achrestus venustus; 189, Ampedus sanguineus; 190, Anoplischius bicarinatus; 191, Atractosomus flavescens; 192, Catalamprus angustus; 193, Crepidius flabellifer; 194, Cyathodera longicornis; 195, Dayakus angularis; 196, Dipropus laticollis; 197, Elius dilatatus; 198, Lampropsephus cyaneus; 200, Physorhinus xanthocephalus; 202, Sphenomerus brunneus. Borders of mesosternal cavity and prosternal spine: 199, Pantolamprus perpulcher; 203, Spilus atractomorphus. Prothorax (lateral): 201, Proloboderus crassipes. Bars $=0.5 \mathrm{~mm}$, except fig. $177=5 \mathrm{~mm}$, figs. $178-185=2 \mathrm{~mm}$, figs. $186,192,194,199,203=1 \mathrm{~mm}$. 
Material examined. BRAZIL. Goiás: Dianópolis, 11-14.I.1962, J. Bechyné, 1 paratype (MZSP). Minas Gerais: Morro da Garça, 1820.X.1964, Exp. Dep. Zoologia, 1 paratype (MZSP); Unaí (Faz. Bolivia), 22-24.xX.1964, Exp. Dep. Zoologia, holotype, 2 paratypes (MZSP).

Cyathodera lanugicollis (Candèze, 1859)

(Figs. 16, 68, 217, 283, 322, 344, 402, 403).

Anoplischius lanugicollis Candèze, 1859: 77

Anoplischius (Cyathodera) lanugicollis; Schenkling, 1925: 81 (cat.); Blackwelder, 1944: 298 (cat.).

Cyathodera lanugicollis; Candèze, 1891: 57 (cat.); Champion, 1895: 304; Heyne \& Taschenberg, 1908: 156.

Length: 22-25 mm. General integument reddish darkbrown. Pubescence yellowish-white, long, fine and dense. Frons carinate, longer than wide, concave longitudinal medially; anterior margin prominent at middle and surpassing nasal; punctuation coarse and dense. Nasal as wide as long. Antennae (Fig. 16) with 11 antennomeres; in male 3.5 antennomeres longer than hind angles of pronotum; subserrate; scape shorter than eye; $2^{\text {nd }}$ antennomere globular, $3^{\text {rd }}$ triangular elongate, shorter than $4^{\text {th }}$, last elliptical; antennomeres with longitudinal median smooth band. Labrum (Fig. 68) subtrapezoidal with long setae. Mandibles narrow with one apical and one subapical tooth; penicillus formed by short setae disposed in whole mesal area; molar area well developed; dorsal region with carina and moderately long setae. Maxillae: galea with simple setae; last palpomere slightly widened to apex. Labium: prementum with setae in front of palpi; postmentum with two long setae and many moderately short. Pronotum (Fig. 217) wider than long, slight- and irregularly convex, narrowed anteriorly; with longitudinal median grooves; anterior margin U-shaped; hind angles carinate, backwardly directed with apex inwardly; median basal tubercle indistinct; punctuation coarse and dense. Prosternal channel long. Prosternal spine with subapical lobe. Borders of mesosternal cavity narrow and declivous. Metacoxal plate strongly narrowed laterally; free margin straight. Tibial spurs very long; tarsomeres 1-3 lamellate beneath. Scutellum subpentagonal with posterior margin rounded. Elytra convex, narrowed apicad; striae coarsely punctuate and grooved; interstices convex and equal.

Male. Tergite 8 elongate, slightly narrowed apicad; anterior margin prominent at middle; punctuate and marginate by setae; clothed with microtrichiae. Sternite 8 (Fig. 283) translucent, darker in a W-shaped area; anterior margin strongly notched at middle; anterior angles rounded; setae distributed irregularly, more concentrate near margins. Sternite 9 (Fig. 322): distal third abruptly narrow to apex; setous near margins and at apex. Tergite 9 (Fig. 344) slightly notched at middle; punctuate; tergite 10 longer than 9; punctuated. Aedeagus (Figs. 402, 403) elongate; basal piece longer than parameres; parameres fused ventrally; median lobe very long, straight, constricted at apex; apex of parameres spatuliform.

Material examined. SURINAME. Ex-coll. Fleutiaux, 1 ex (MNHN).
FRENCH GUIANA. Gourdonville, ex-coll. Le Moult, 1 ex. (MNHN); Saint Laurent du Maroni, ex- coll. Le Moult, 1 ex. (MNHN).

Cyathodera longicornis Blanchard, 1843

(Figs. 17, 69, 121, 122, 194, 218, 284, 323, 345, 404, 405, 477).

Cyathodera longicornis Blanchard, 1843: 130; Candèze, 1891:57 (cat.). Anoplischius longicornis; Candèze, 1859: 76.

Anoplischius (Cyathodera) longicornis; Schenkling, 1925:81 (cat.); Blackwelder, 1944: 298.

Length: 23-36 mm. General integument from dark-brown to reddish dark-brown; pronotum, antennae and legs slightly darker. Pubescence long, very dense and yellowish; on elytra, denser on lower interstices giving to elytra a stripped appearance. Frons carinate, longer than wide, concave in a longitudinal median area; anterior margin prominent at middle and surpassing nasal; punctuation coarse and sparse. Nasal as wide as long. Antennae (Fig. 17) with 11 antennomeres; in male 4.2 antennomeres longer than hind angles of pronotum; subserrate in both sexes; scape shorter than eye; $2^{\text {nd }}$ antennomere globular, $3^{\text {rd }}$ triangular elongate, as long as $4^{\text {th }}$, last narrowed at apex; antennomeres with longitudinal smooth band. Labrum (Fig. 69) semielliptical with anterior margin notched at middle and with long setae. Mandibles (Figs. 121, 122) narrow with one apical and one subapical tooth; penicillus formed by short setae disposed in whole mesal area; molar area well developed; dorsal region with carina and moderadely long setae. Maxillae: galea with simple setae; last palpomere slightly widened to apex. Labium: prementum with setae in front of palpi; postmentum with two long setae and many moderately short. Pronotum (Fig. 218) wider than long, slightand irregularly convex; with 3 longitudinal grooves: a longitudinal median longer and one shorter near each hind angle; lateral margins carinate; anterior prominent at middle; hind angles long, divergent and carinate; median basal tubercle indistinct; punctuation coarse, sparse, irregularly distributed. Prosternal channel long. Prosternal spine (Fig. 194) with narrowed and rounded apex. Borders of mesosternal cavity narrow and declivous. Metacoxal plate strongly narrowed laterally; free margin almost straight. Tibial spurs very long; tarsomeres 1-3 lamellate beneath. Scutellum elongate, narrowed apicad; apex rounded. Elytra convex, slightly narrowed apicad; apex with sutural spine; striae coarsely punctuate, grooved at base; interstices equal in width; $1,3,5$, 7, flat; $2,4,6$, convex.

Male. Tergite 8 elongate with anterior margin rounded; punctuate and marginate by setae; clothed with microtrichiae. Sternite 8 (Fig. 284) translucent in a median basal area; anterior margin strongly notched at middle; anterior angles rounded; setae distributed irregularly, more concentrate near angles. Sternite 9 (Fig. 323): distal third abruptly narrow to apex; punctuate and setous near apex. Tergite 9 (Fig. 345) moderately notched at middle; punctuate; tergite 10 longer than 9 with distal margin straight; punctuated. Aedeagus (Figs. 404, 405) elongate; basal piece longer than parameres; 


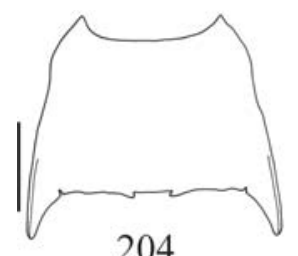

204
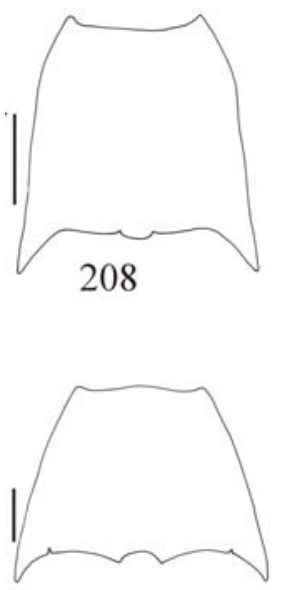

212

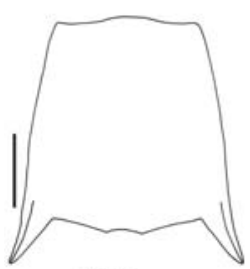

216

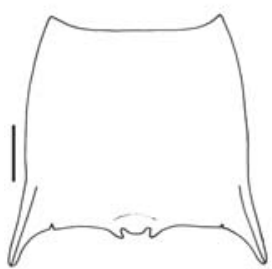

220

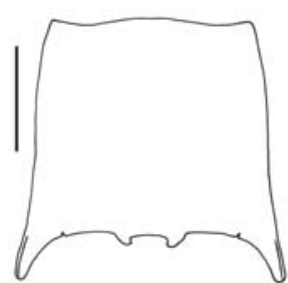

224

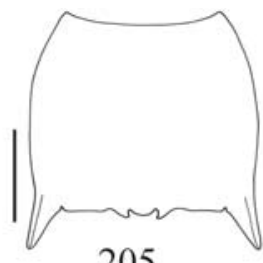

205

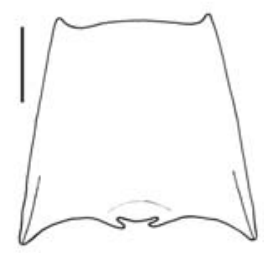

209

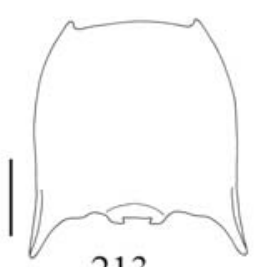

213

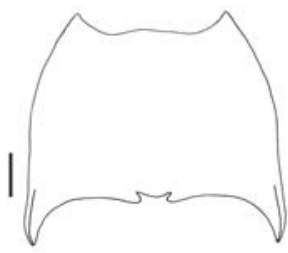

217

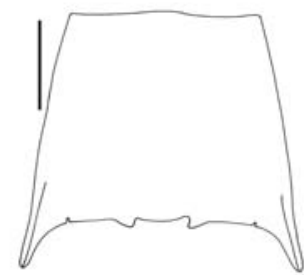

221

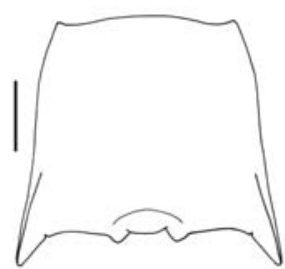

225

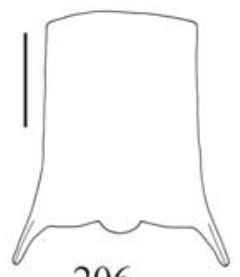

206

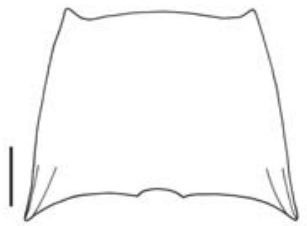

210

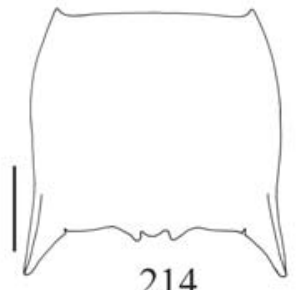

214

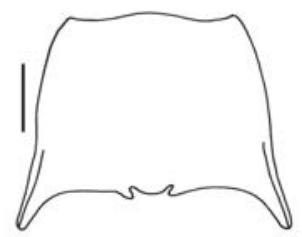

218

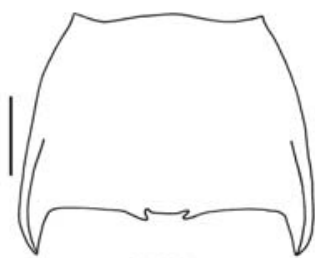

222

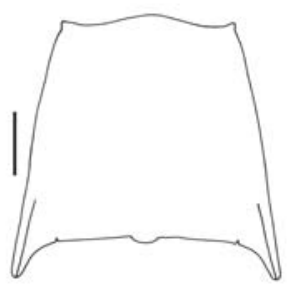

226

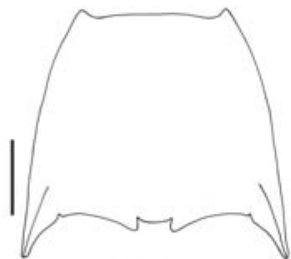

207

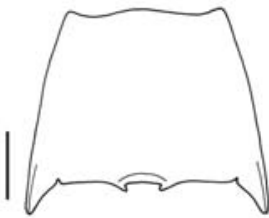

211

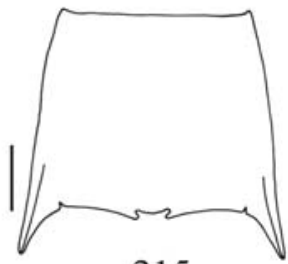

215

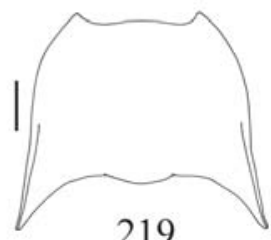

219

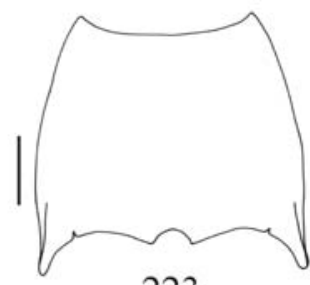

223

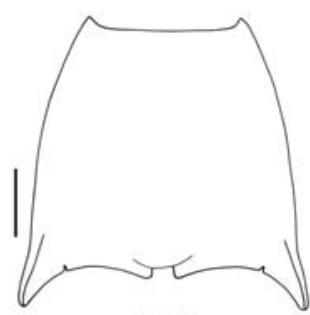

227

Figs. 204- 227. Pronotum: 204, Achrestus flavocinctus; 205, Achrestus venustus; 206, Adiaphorus ponticerianus; 207, Ampedus sanguineus; 208, Anchastus digittatus; 209, Anoplischiopsis bivittatus; 210, Anoplischius bicarinatus; 211, Anoplischius haematopus; 212, Atractosomus flavescens; 213, Calopsephus apicalis; 214, Catalamprus angustus; 215, Crepidius flabellifer; 216, Ctenicera silvatica; 217, Cyathodera lanugicollis; 218, Cyathodera longicornis; 219, Dayakus angularis; 220, Dicrepidius ramicornis; 221, Dipropus brasilianus; 222, Dipropus laticollis; 223, Dipropus pinguis; 224, Dipropus schwarzi; 225, Elius birmanicus; 226, Elius dilatatus; 227, Lampropsephus cyaneus. Bars = 1 $\mathrm{mm}$. 
parameres fused ventrally; median lobe very long, narrow, much longer than parameres, narrowed at base and constricted at apex; apex of parameres spatuliform, slitted subapically.

Female. Tergite 8 elongate with anterior margin rounded; setous near margins. Sternite 8 (Fig. 477) rounded, clothed with short setae; spiculum gastrale 4.14 times sternite length. Ovipositor with stylus; bursa copulatrix without spines or sclerotized pieces.

Material examined. BRAZIL. Amazonas: Itacoatiara, 1 ex. (MZSP). Ceará: Carquejo, 2 exs. (MZSP). Goiás: Arauna (Rio Araguaia), 1 ex. (MZSP); Colinas do Sul (Serra da Mesa) (14o 01'S 48o 12`W), 1 ex. (MZSP); Jataí, ex-coll. Fleutiaux, 1 ex. (MNHN); (Faz. Nova Orlândia), 2 exs. (MZSP); Km 42, Rodovia Brasília-Goiânia, 1 ex. (MZSP). Mato Grosso: Bodoquena, 1 ex. (MZSP); Guaicurus, 1 ex. (MZSP); Rondonópolis, 1 ex. (MZSP); Salobra, Instituto Oswaldo Cruz, Zona N.O.B. 7 exs. (MZSP); Três Lagoas, 1 ex. (MZSP). Bahia: ex-coll. Fleutiaux, 1 ex. (MNHN); Maracas (Faz. Inácio), 6 exs. (MZSP); Nova Conquista, 4 exs.(MZSP). Pernambuco: Jaboatão, 1 ex.; Porto Alegre, 1 ex.; Recife, 1 ex. (MZSP). Minas Gerais: Buritis (Ribeirão Confins), 1 ex. (MZSP); Morro da Garça, 1 ex. (MZSP); Passos, 2 exs. (MZSP); Pedra Azul, 1 ex. (MZSP); Uberaba, ex-coll. Fleutiaux, 1 ex. (MNHN); Unaí (Faz. Bolívia), 1 ex. (MZSP); Viçosa, 1 ex. (MZSP). Rio de Janeiro: Parque Nacional do Itatiaia, 4 exs. (MZSP). São Paulo: Alto da Serra, 2 exs. (MZSP); Barueri, 7 exs. (MZSP); Batatais, 1 ex. (MZSP); Botucatu, 25 exs. (MZSP); Cajuru (Cassia dos Coqueiros), 1 ex. (MZSP); Campinas, 1 ex. (MZSP); Dois Córregos, 1 ex. (MZSP); Estac. R. d. S. - E.S.P., 2 exs. (MZSP); Itu, 2 exs.(MZSP); Itu (Faz. Pau d'Alho), 2 exs. (MZSP); Jundiaí, 2 exs. (MZSP); Pindamonhangaba (Eugênio Lefreve), 2 exs.(MZSP); Piracicaba, 4 exs. (MZSP); Pirassununga, 1 ex. (MZSP); Rio Claro, 1 ex. (MZSP); Santo André, 2 exs. (MZSP); São Bernardo, 1 ex. (MZSP); São Paulo, 2 exs. (MZSP); São Paulo (Ipiranga), 10 exs. (MZSP); São Paulo (Jabaquara), 2 exs. (MZSP); Sorocaba, 1 ex. (MZSP); Suzano, 2 exs.(MZSP). BOLIVIA. Santa Cruz: Buenavista, 2 exs. (MZSP).

\section{Dayakus Candèze, 1893}

Dayakus Candèze, 1893: 22; Schwarz, 1906: 59, 63; Schenkling, 1925: 76 (cat.); Cobos, 1970: 45.

Eupsephus Fleutiaux, 1935a: 204; 1935b: 305; Basilewsky, 1958: 379 (syn.).

Type-species: Dayakus angularis Candéze, 1893 designated by monotypy.

Candèze (1893) erected Dayakus to D. angularis from Borneo.

Schenkling (1925) catalogued one species to this genus.

Fleutiaux (1935a) erected Eupsephus to two new species, E. dilaticollis from Kenya and E. bisulcatus from Tanzania.

Basilewsky (1958) synonymized Eupsephus Fleutiaux under Dayakus, redescribed the genus and D. angularis Candèze, 1895 and considered D. congoensis Fleutiaux, 1935 as synonym of the latter. He also transferred Eupsephus dilaticollis Fleutiaux and E. bisulcatus Fleutiaux to Dayakus. He illustrated the aedeagus of $D$. angularis.

Cobos (1970) described two new species, D. villiersi and D. basilewskyi. He also presented an identification key to the 5 species described until that momment.

Girard (1971) presented a new combination of one species belonged to Psephus: Dayakus capillatus (Candèze, 1889).

The genus Dayakus is formed by 6 species: D. angularis Candèze, 1893 (=Eupsephus congoensis Fleutiaux), D. basilewskyi Cobos, 1970, D. bisulcatus (Fleutiaux, 1935), D. capillatus (Candèze, 1889), D. dilaticollis (Fleutiaux, 1935), D. villiersi Cobos, 1970. It is recorded from Democratic Republic of Congo, Kenya, Tanzania and Borneo.

Dayakus angularis is characterized by homoplasies, 4(1) median anterior region of frons concave, 15(1) antennae of male 2.5-4.4 antennomeres longer than hind angles of pronotum, 21(0) mesal area of mandibles with one apical tooth, 25(2) setae of galea short bristle, 36(1) lateral margin of metacoxal plate slightly narrowed, 56(1) sternite 8 of male gradually narrowed to apex, 57(1) anterior margin of sternite 8 of male narrowed and straight, 58(5) distal margin of tergite 9 of male rounded, 62(2) basal piece longer than parameres and 65(7) subapical region of parameres securiform with tooth. It is the sister-group of Achrestus flavocinctus.

Dayakus angularis Candèze, 1893

(Figs. 18, 70, 123, 124, 164, 195, 219, 259, 285, 346, 406, 407).

Dayakus angularis Candèze, 1893: 22; Schenkling, 1925: 76 (cat.).

Length: 14.0-14.5 mm. General integument reddish-brown. Pubescence golden, long and very dense. Frons carinate, wider than long, prominent and declivous medioanteriorly, not surpassing nasal; punctuation thin and dense. Nasal wider than long. Antennae (Fig. 18) with 11 antennomeres; in male 2.5 antennomeres longer than hind angles of pronotum; serrate; scape shorter than eye; $2^{\text {nd }}$ antennomere globular, $3^{\text {rd }}$ triangular, shorter than $4^{\text {th }}$, last narrowed at apex. Labrum (Fig. 70) semielliptical, with long setae. Mandibles (Figs. 123, 124) with one apical tooth; penicillus formed by short setae disposed in whole mesal area; dorsal region with carina and moderately long setae. Maxillae (Fig. 164): galea with thick short setae, giving a bristle appearance; last palpomere securiform. Labium: prementum with setae in front of palpi; postmentum without two long setae and with many moderately short. Pronotum (Fig. 219) wider than long, narrowed anteriorly; lateral margins incompletely carinate; anterior margin straight; hind angles very wide, backwardly directed and carinate; median basal tubercle indistinct with posterior margin raised; punctuation small and dense. Prosternal channel absent. Prosternal spine (Fig. 195) with sharpened apex. Borders of mesosternal cavity raised and declivous. Metacoxal plate (Fig. 259) slightly narrowed laterally; free margin with well developed lobe. Tibial spurs long; tarsomeres 1-3 lamellate beneath. Scutellum subtriangular elongate, with posterior margin rounded. Elytra narrower than pronotum, slightly convex and slightly narrowed apicad; striae grooved; interstices flat and equal.

Male. Tergite 8 wider than long, slightly narrowed to apex; anterior margin rounded; punctuate and setous near margins and at apex. Sternite 8 (Fig. 285) translucent in a median basal area; wider than long and trapezoidal; anterior margin narrow and straight; anterior angles rounded; setae denser on distal half. Sternite 9: distal half gradually narrowed to apex; apical third setous. Tergite 9 (Fig. 346) almost straight 


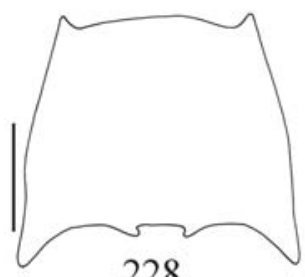

228
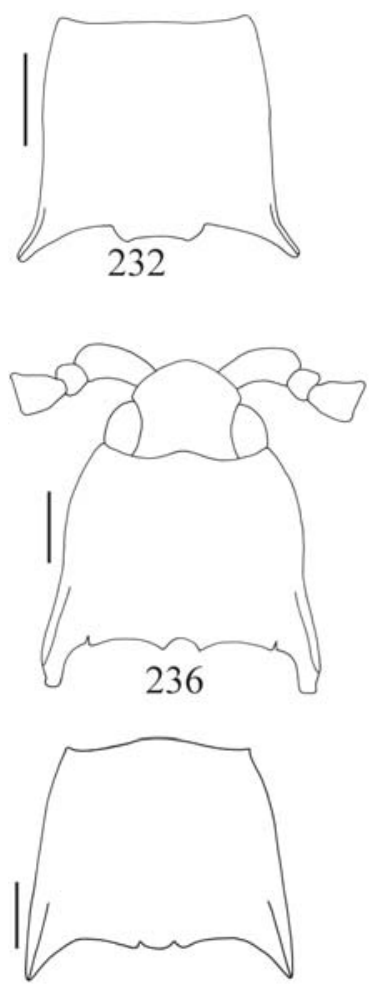

240

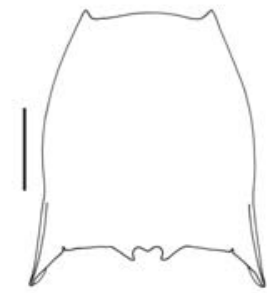

244

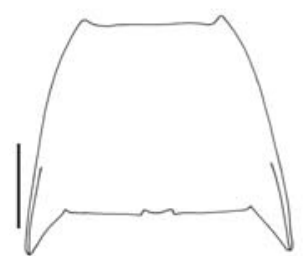

248

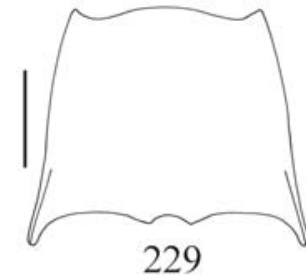

229
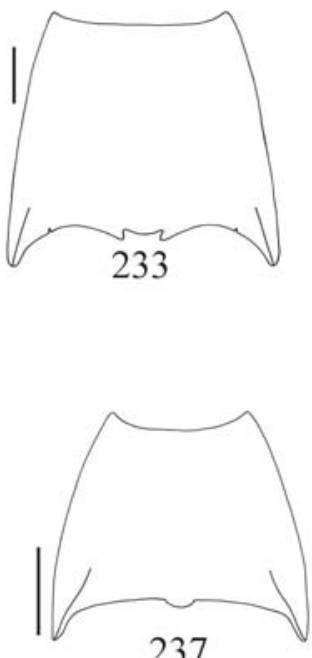

237

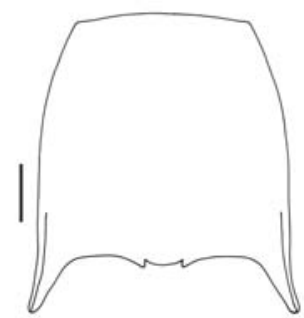

241

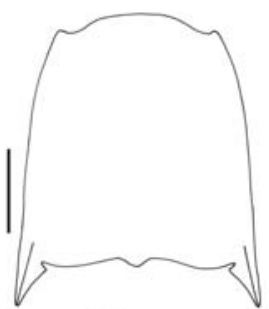

245

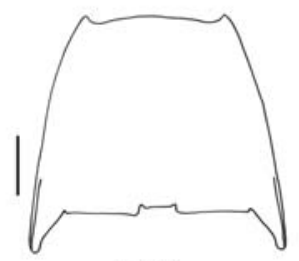

249
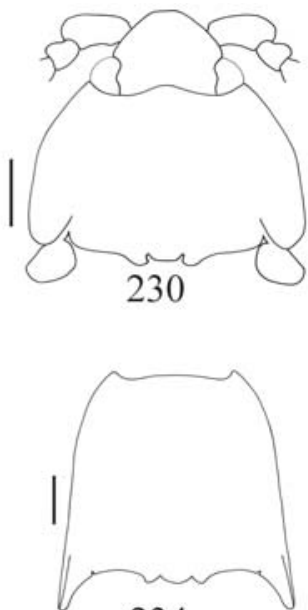

234
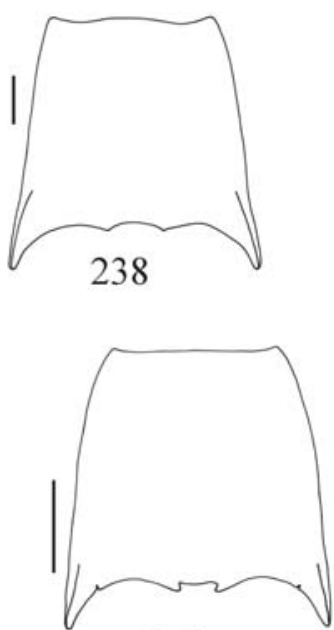

242

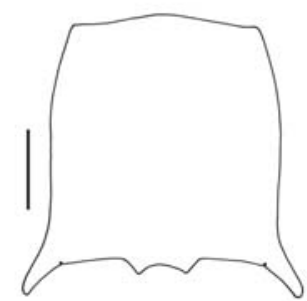

246

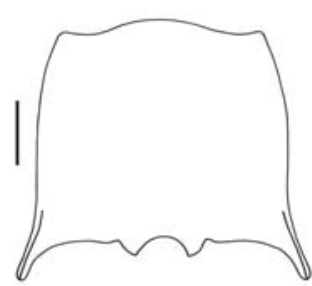

250
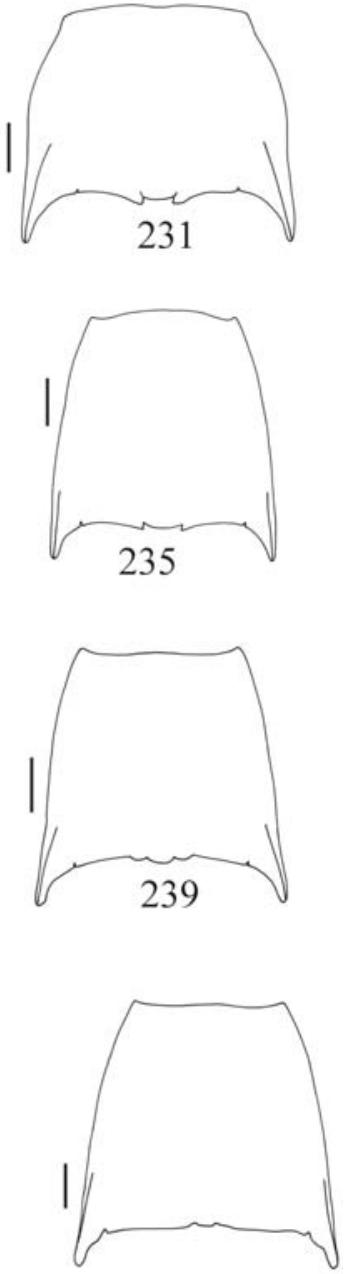

243

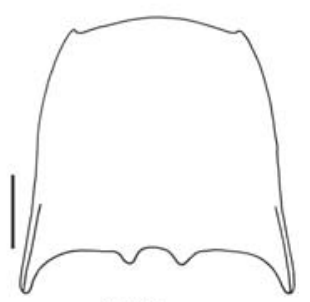

247

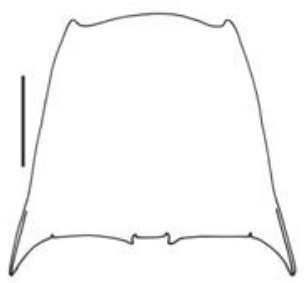

251

Figs. 228-251. Pronotum: 228, Heterocrepidius gilvellus; 229, Heterocrepidius ventralis; 230, Loboederus appendiculatus; 231, Olophoeus gibbus; 232, Ovipalpus pubescens; 233, Pantolamprus ligneus; 234, Pantolamprus mirabilis; 235, Pantolamprus perpulcher; 236, Paraloboderus glaber; 237, Physorhinus xanthocephalus; 238, Propsephus beniensis; 239, Propsephus cavifrons; 240, Pseudolophoeus guineensis; 241, Rhinopsephus apicalis; 242, Sephilus formosanus; 243, Sephilus frontalis; 244, Singhalenus gibbus; 245, Singhalenus taprobanicus; 246, Sphenomerus antennalis; 247, Sphenomerus brunneus; 248, Spilus atractomorphus; 249, Spilus nitidus; 250, Stenocrepidius simoni; 251, Trielasmus varians. Bars $=1 \mathrm{~mm}$. 
medioanteriorly; coarsely punctuate; tergite 10 small, shorter than 9, punctuated and with setae near apex. Aedeagus (Figs. 406, 407) elongate; basal piece longer than parameres; parameres fused ventrally; median lobe slightly longer than parameres, widened near base and constricted at apex; apex of parameres with subapical tooth preceded by lobe.

Material examined. DEMOCRATIC REPUBLIC OF CONGO. (Congo Belge) Kinda Katanga. 5 exs. (MNHN); Lubumbashi (Elisabethville), 1 ex. (MNHN).

\section{Dicrepidius Eschscholtz, 1829}

Dicrepidius Eschscholtz, 1829: 31: Candèze, 1859: 10, 144; 1891: 64 (cat.); Champion, 1894: 293; Schwarz, 1906: 59, 74; Blatchley, 1910: 719, 729; Schenkling, 1925: 85 (cat.); Blackwelder, 1944: 298 (cat.).

Type-species: Elater ramicornis Palisot de Beauvois, 1805, designated by Hyslop, 1921.

Eschscholtz (1829) erected Dicrepidius for 5 species from Brazil: D. pectinicornis (Rio de Janeiro), D. laticollis (Bahia), D. abdominalis (Rio de Janeiro), D. marginellus (Rio de Janeiro), D. conicollis (Bahia).

Candèze (1859) redescribed the genus and described 3 species (D. corvinus, D. palmatus, $D$. thoracicus). The genus was formed by 8 species. After treating the genus Dicrepidius, just before the "sous-tribu II. Eudactylites", he included: "Plusiers espèces qui doivent probablement rentrer dans la sous-tribu actuelle me sont restées inconnues. Je reproduis ci-dessous leur description." He included Dicrepidius abdominalis Eschscholtz, 1829 [later transferred to Ischiodontus], D. anguinus Erichson, 1847 [later transferred to Anoplischius], D. atricornis Erichson, 1848 [later transferred to Atractosomus], D. conicollis Eschscholtz, 1829 [later transferred to Ischiodontus], D. fuscescens Blanch., 1837 [later transferred to Ischiodontus], D. ferreus Le Conte, 1853 [later transferred to Ischiodontus], D. macullicolis Blanchard, [later transferred to Anoplischius], D. marginellus Eschscholtz, 1829 [later tranferred to Ischiodontus], D. porosus Erichson, 1848 [later transferred to Ischiodontus], D. planicollis Erichson, 1847 [later transferred to Anoplischius], D. simplex LeConte, 1857 [later transferred to Ischiodontus], D. soleatus Say, 1836 [later transferred to Ischiodontus], D. unicolor Blanch., 1843 [later transferred to Ischiodontus], Hemicrepidius ruficollis Blanch., 1843[later transferred to Ischiodontus] and Trielasmus varians Blanch., 1843 [kept in Trielasmus].

Candèze (1891) catalogued 5 species to this genus.

Champion (1895) described two new species, D. politus and D. serraticornis. He also redescribed D. ramicornis Beauv.and D. corvinus Candèze.

Schwarz (1906) included 10 species into the genus.

Hyslop (1921) designated Dicrepidius pectinicornis Eschscholtz, 1829 as type species of this genus. According to him, Gemminger and Harold (1869) reduced the type to synonymy under Dicrepidius ramicornis Palisot de Beauvois, 1805.
Schenkling (1925) catalogued 10 species to this genus. Blackwelder (1944) catalogued 9 species to this genus.

The genus Dicrepidius is formed by 11 species: $D$. cavifrons Candèze, 1881, D. corvinus Candèze, 1859, D. distinctus Fleutiaux, 1911, D. elegans Fleutiaux \& Sallé 1889, D. ignotus Fleutiaux \& Sallé 1889, D. insularis Champion, 1897, D. palmatus Candèze, 1859, D. politus Champion, 1894, D. ramicornis (Palisot Beauvois 1805), (= D. pectinicornis Esch., 1829, = Elater ceramboides Sturm, 1826), D. serraticornis Champion, 1894, D. thoracicus Candèze, 1859. It is recorded from North America (United States (Arizona, Texas, Indiana, South Carolina), Mexico), Central America (Guatemala, Belize, Nicaragua, Panama), Antilles (Cuba, Guadeloupe, St Vicent, Grenada), South America (Colombia, Brazil, Argentina).

Dicrepidius ramicornis is characterized by homoplasies, 2(2) anterior margin of frons prominent at middle, 3(0) anterior margin of frons at nasal level, 6(0) ridge of nasal present, 18(5) labrum narrow band-like, 36(2) lateral margin of metacoxal plate widened laterally, 56(1) sternite 8 of male gradually narrowed at apex and 67(4) lateral margins of median lobe slightly narrowed at distal half. It is the sister-group of Crepidius.

Dicrepidius ramicornis (Palisot de Beauvois 1805) (Figs. 71, 125, 126, 155, 220, 260, 286, 347, 408, 409, 478, 506).

Elater ramicornis Palisot de Beauvois 1805: 21.

Dicrepidius ramicornis; Germar, 1839: 214; Jacquelin Du Val, 1857: 69; Candèze, 1859: 144; Chevrolat, 1867: 600; Fleutiaux \& Sallé, 1889: 409; Champion, 1894: 293; Heyne \& Taschenberg, 1908: 156; Fleutiaux, 1911: 251; Schenkling, 1925: 85 (cat.); Blackwelder, 1944: 298 (Cat.).

Dicrepidius pectinicornis Esch., 1829: 31; Gemminger \& Harold, 1869: 1605 (syn.)

Elater ceramboides Sturm, 1826: 135.

Length: 15.5-25.5 mm. General integument reddish-brown. Pubescence yellowish, fine, moderately long and moderately dense. Frons carinate, longer than wide, convex; anterior margin prominent at middle; punctuation fine and dense. Nasal (Fig. 155) wider than long, with two inclined ridges. Antennae with 11 antennomeres; in male 2.5 antennomeres longer than hind angles of pronotum; flabellate in male, serrate in female; scape shorter than eye; $2^{\text {nd }}$ antennomere globular, $3^{\text {rd }}$ with lateral appendix, shorter than $4^{\text {th }}$, short in female; last narrowed at apex. Labrum (Fig. 71) like narrow band, with long setae on distal half. Mandibles (Figs. 125, 126) wide with one subapical tooth; with one small tooth at beginning of penicillus; penicillus formed by short setae disposed in whole mesal area; molar area well developed; dorsal region with carina and moderately long setae. Maxillae: galea with spatulate setae; last palpomere securiform. Labium: prementum with long setae in front of palpi; postmentum with two long setae and some moderately short. Pronotum (Fig. 220) slightly wider than long, slightly narrowed anteriorly; moderately convex; lateral margins carinate; anterior margin slightly notched; hind angles slightly divergent and carinate; median basal tubercle flat; 


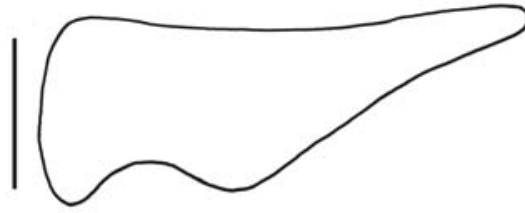

252

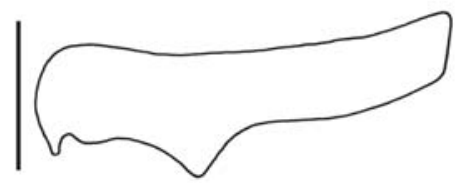

255
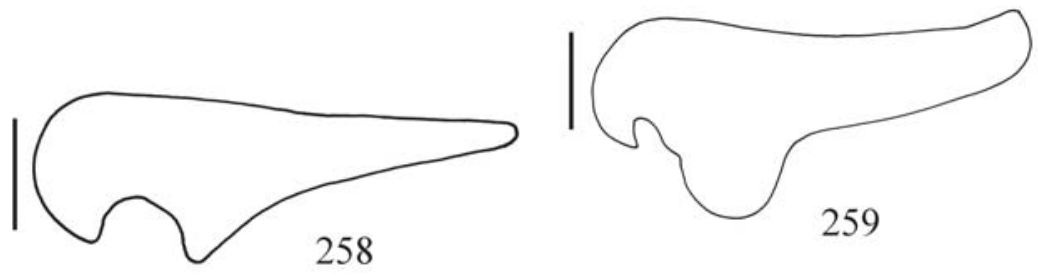

256
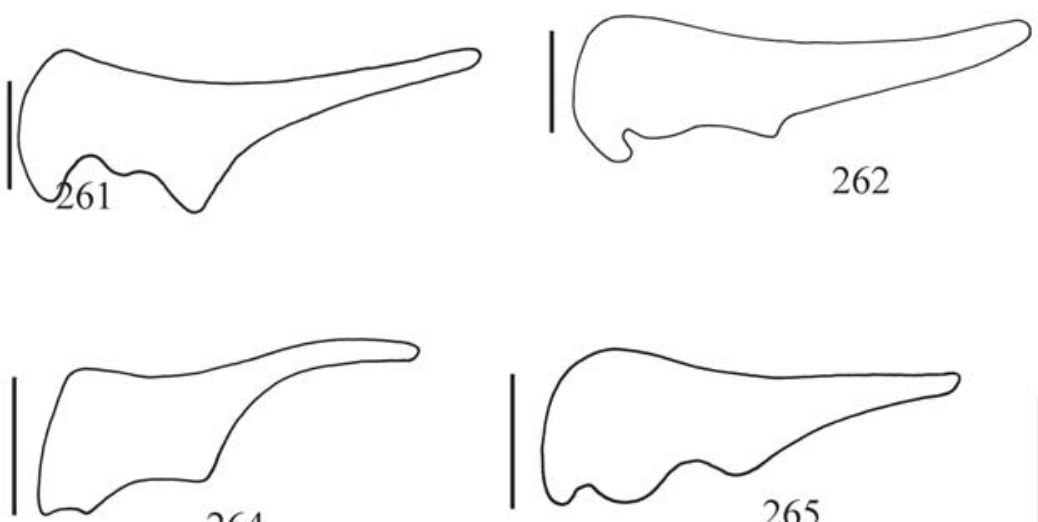

264

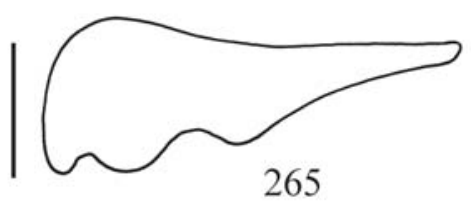

265

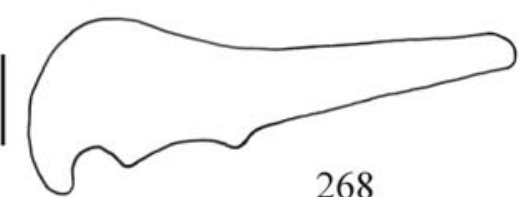

267

268

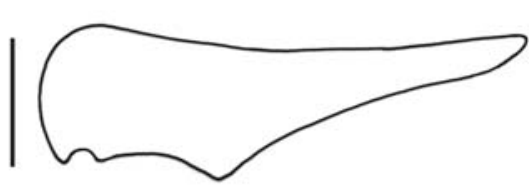

271
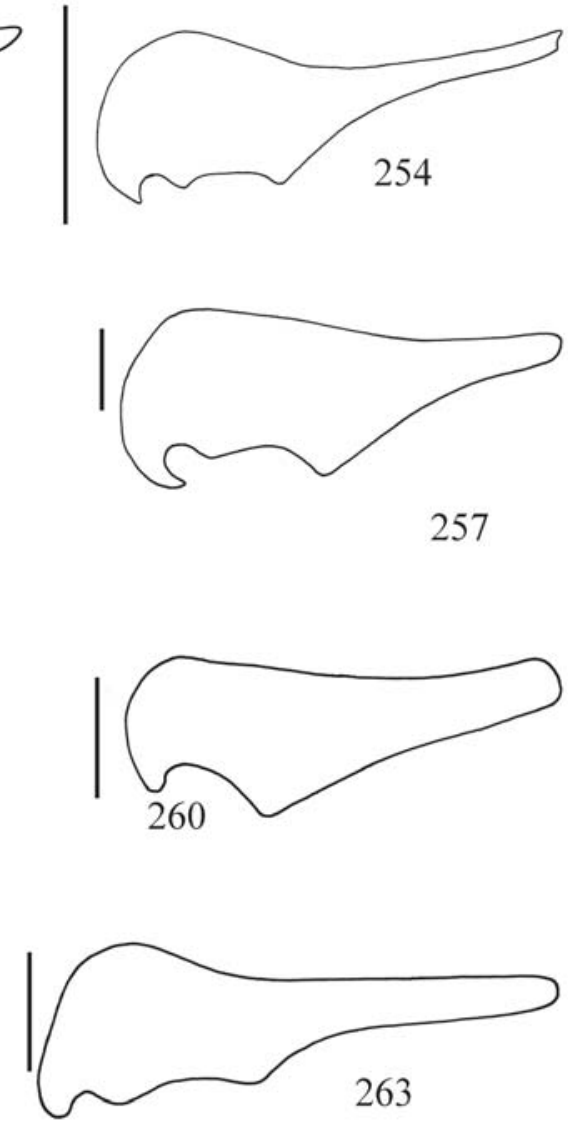

257
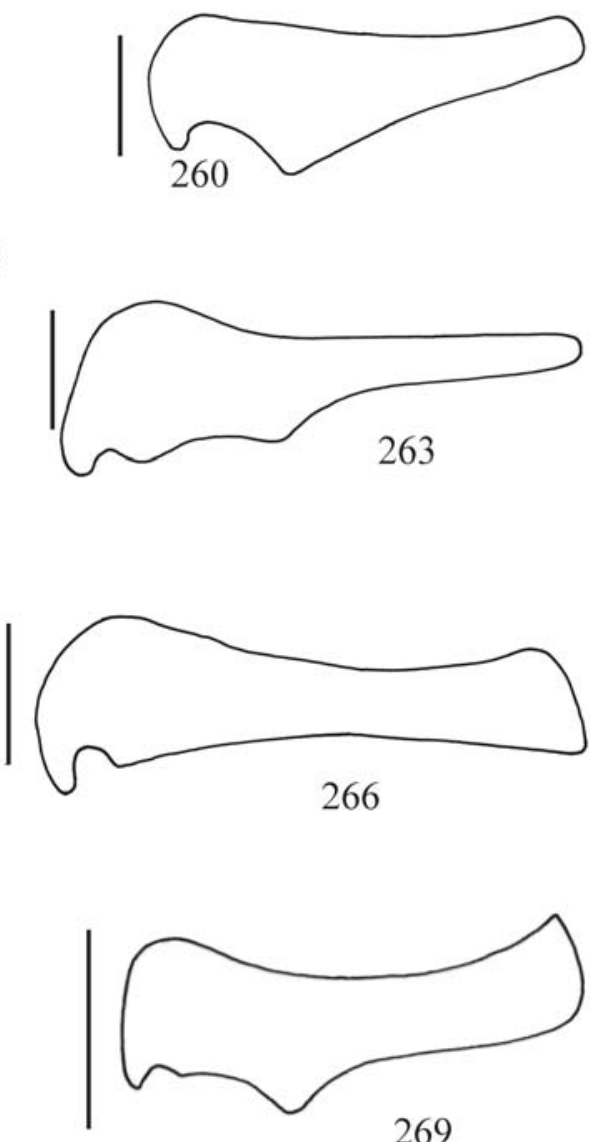

269

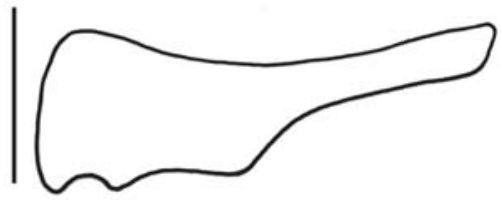

272

Figs. 252-272. Placa metacoxal: 252, Ampedus sanguineus; 253, Anchastus digittatus; 254, Blauta cribraria; 255, Calopsephus apicalis; 256, Catalamprus angustus; 257, Crepidius flabellifer; 258, Crepidius resectus; 259, Dayakus angularis; 260, Dicrepidius ramicornis; 261, Dipropus brasilianus; 262, Dipropus pinguis; 263, Elius birmanicus; 264, Heterocrepidius gilvellus; 265, Heterocrepidius ventralis; 266, Ovipalpus pubescens; 267, Physorhinus xanthocephalus; 268, Propsephus beniensis; 269, Rhinopsephus apicalis; 270, Sephilus formosanus; 271, Spilus atractomorphus; 272, Stenocrepidius simoni. Bars $=1 \mathrm{~mm}$. 
punctuation moderately coarse and moderately dense. Prosternal channel absent. Prosternal spine with subapical tooth. Borders of mesosternal cavity horizontal and declivous. Metacoxal plate (Fig. 260) strongly narrowed laterally; free margin with well developed tooth. Tibial spurs short; tarsomeres 1-3 lamellate beneath. Scutellum elongate with posterior margin rounded. Elytra convex, narrowed apicad; striae grooved at base, marked by coarse punctures; interstices narrow, equal and flat, except basal region convex.

Male. Tergite 8 elongate, slightly narrowed to apex; anterior margin rounded; marginate by setae; clothed with microtrichiae. Sternite 8 (Fig. 286) trapezoidal, translucent in a median basal area; anterior margin slightly notched at middle; setae distributed on distal half. Sternite 9: distal half gradually narrow to apex; setous near apex. Tergite 9 (Fig. 347) slightly notched at middle; punctuate with some setae near angles; tergite 10 as long as 9 , punctuate and with some setae laterally. Aedeagus (Figs. 408, 409) elongate; basal piece much longer than parameres; parameres fused ventrally; median lobe moderately longer than parameres, narrowed near base and at apex; apex of parameres cuneiform.

Female. Tergite 8 elongate, abruptly narrowed on distal third; anterior margin narrow with rounded angles; setae irregularly distributed. Sternite 8 (Fig. 478) elongate, narrowed to apex; short setae on distal half; marginal setae longer; spiculum gastrale 5.18 times sternite length. Ovipositor with stylus; bursa copulatrix (Fig. 506) with 4 spiny areas; spines forming continuing areas.

Material examined. BRAZIL. Minas Gerais: 1 ex. (MNHN). São Paulo: 1 ex. (MZSP); Botucatu, 2 exs. (MZSP). Santa Catarina: Canoinhas, 1 ex. (MZSP); Mafra, 1 ex. (MNHN); Pinhal, 1 ex. (MZSP); Rio Vermelho, 1 ex. (MZSP); Timbó, 1 ex. (MZSP).

\section{Dipropus Germar, 1839}

Dipropus Germar, 1839: 216.

Dipropus (pars); Candèze, 1859: 49, 90; Schenkling, 1925: 78, 88 (cat.) (syn. Anoplischius and Ischiodontus).

Ischiodontus Candèze, 1859: 10, 90; 1891: 60 (cat.); Champion, 1895: 316; Schwarz, 1906: 61, 76; Blatchley, 1910: 719, 729; Schenkling, 1925: 88 (cat.); Blackwelder, 1944: 299 (cat.); Arnett, 1962: 505 (syn.). Atractodes (pars) Germar, 1839: 220, 221.

Heterocrepidius Lacordaire, 1857: 170.

Tricrepidius Motschulsky, 1859: 366.

Type-species: Elater pexus Germar, 1824, designated by Hyslop, 1921.

Germar (1839) erected the genus Dipropus to three species from Brazil: Elater brasilianus Germar, 1824, E. pexus Germar, 1824 and Dicrepidius laticollis Eschscholtz, 1829.

Candèze (1859) erected Ischiodontus to 63 species, from tropical region of America and Africa. He presented a key and descriptions for all species. According to him, the uniformity of the genus makes the specific characterization very difficult. He considered Dipropus as synonym of Anoplischius and Ischiodontus. The species that originally were included into Dipropus are now Anoplischius laticollis, Ischiodontus brasilianus and I. pexus.
Candèze (1891) catalogued 68 species separated into two groups according to the size of $3^{\text {rd }}$ antennomere.

Champion (1895) treating of Ischiodontus, described 24 species and stated that this genus contain 70 described species, all American, from Southern United States to Uruguay, except I. hawaiensis Candèze, introduced to Sandwich Island. Of this number, 65 are from tropical America, three of these inhabiting the Antilles. He presented a key where some items are for more than one species, following the Candèze's idea of difficulties in identifying the species.

Schwarz (1906) included 113 species in Ischiodontus.

Hyslop (1921) designated Ischiodontus pinguis Candèze, 1859 as type species of the Ischiodontus and Elater pexus Germar, 1824 as type species of Dipropus.

Schenkling (1925) followed Candèze (1859) and catalogued 124 species to Ischiodontus.

Fall (1925) described Ischiodontus granulosus from Palm Beach, Florida.

Blackwelder (1944) catalogued 123 species to Ischiodontus.

Becker (1961) gave a new name, Ischiodontus schwarzi, to I. parallelus Schwarz, 1906 and designated the Lectotype.

Arnett (1962) synonymyzed Ischiodontus Candèze, 1859 under Dipropus Germar, 1839, without references about the species included in the genus.

Chassain (1979) studying the faune from "Antilles Françaises" synonymized Ischiodontus convexus Fleutiaux \& Sallé, 1890 under Crepidius rhipihorus Candèze, 1859.

Suzuki (1988) recorded Ischiodontus hawaii from Chiba Prefecture (Central Japan).

Golbach (1994) followed Arnett (l.c.) and recorded 10 species of Dipropus to Argentina: 8 from Ischiodontus and 2 from Dicrepidius.

Johnson (2002a) treating of the classification of the Neartic genera of Elateridae, kept Ischiodontus Candèze, 1859 as synonym and cited 8 species from "southeastern states to California".

Johnson (2002b) designated the Lectotype and Paralectotypes to Ischiodontus species described by Champion, 1895 and later transferred to Dipropus.

The genus Dipropus is formed by about 150 species. It is recorded from North America (United States of America (Michigan, Ohio, Indiana, Texas, Alabama, Florida), Mexico), Central America (Guatemala, Belize, Honduras, Nicaragua, Costa Rica, Panama), Antilles (Cuba, Hispaniola, Guadeloupe, Martinique, Grenada), South America (Colombia, Venezuela, Guyana, Suriname, Brazil, Ecuador, Peru, Bolivia, Chile, Paraguay, Argentina, Uruguay).

The Dipropus species included in this analysis do not form a monophyletic group. The monophyletic group ( $(D$. pinguis $)((D$. brasilianus $)(D$.factuellus $)))$ is characterized by homoplasies, 34(1) prosternal spine with rounded apex, 40(0) tibial spurs short, 42(1) lamella of protarsomere 1 absent, 43(1) lamella of mesotarsomere 1 absent and 44(1) lamella of metatarsomere 1 absent. It belongs to a monophyletic group formed by a large polytomy that includes some genera and 


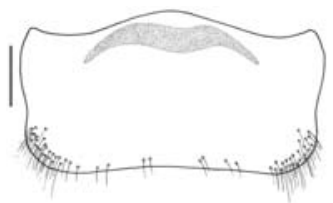

273

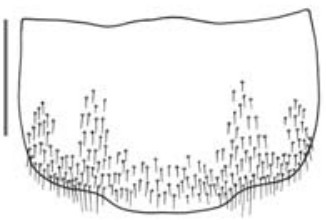

277

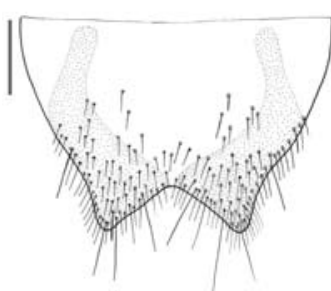

281

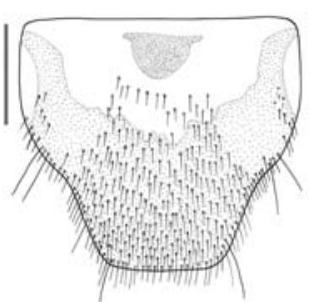

285

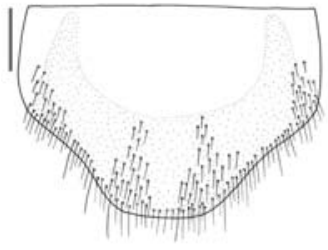

289

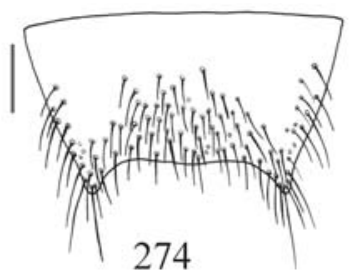

274

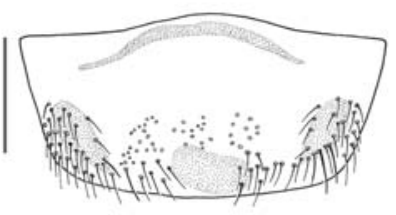

278

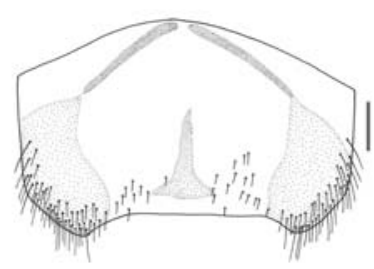

282

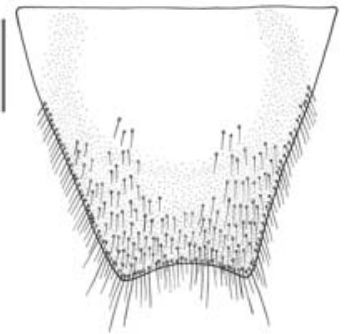

286

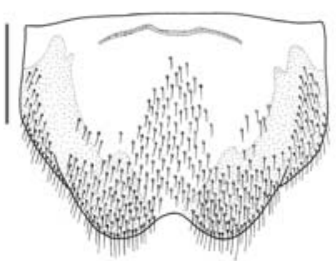

290

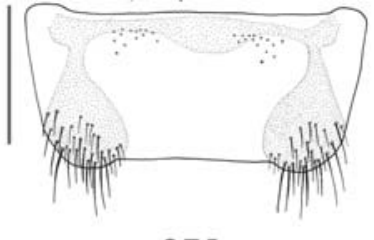

275

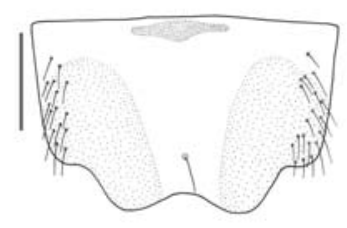

279

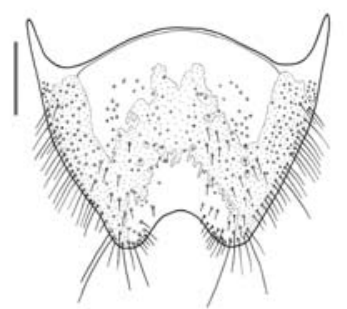

283

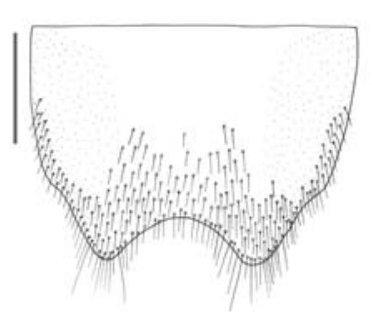

287

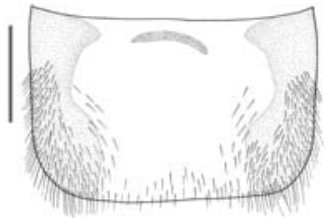

276

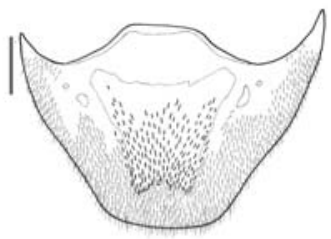

280

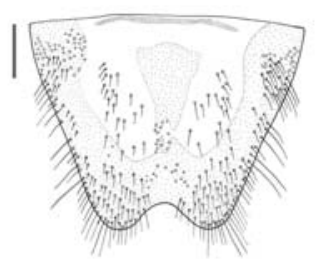

284

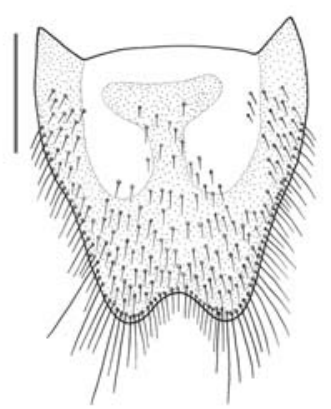

288

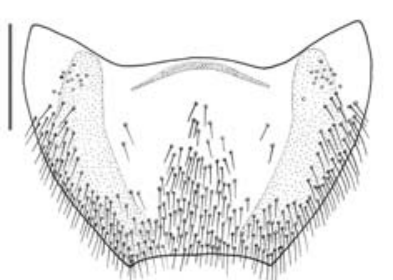

291

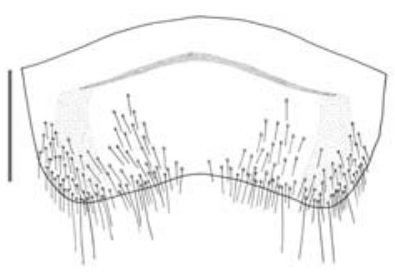

292

Figs. 273-292. Sternite 8 of male: 273, Achrestus flavocinctus; 274, Adiaphorus ponticerianus; 275, Ampedus sanguineus; 276, Anoplischius haematopus; 277, Atractosomus flavescens; 278, Blauta cribraria; 279, Calopsephus apicalis; 280, Chalcolepidius zonatus; 281, Crepidius flabellifer; 282, Ctenicera silvatica; 283, Cyathodera lanugicollis; 284, Cyathodera longicornis; 285, Dayakus angularis; 286, Dicrepidius ramicornis; 287, Dipropus brasilianus; 288, Dipropus laticollis; 289, Dipropus schwarzi; 290, Elius birmanicus; 291, Elius dilatatus; 292, Lampropsephus cyaneus. Bars = 2 mm, except figs. 275, 278, 281, 285, 287, 288, 292 = 5 mm, figs. 276 , 277, $280,286,290,291=1 \mathrm{~mm}$. 
several groups of genera. $D$. schwarzi is characterized by homoplasies, 2(3) anterior margin of frons straight, 27(1) last palpomere slightly widened apicad and 37(4) free margin of metacoxal plate with small tooth. It is the sister-group of Anoplischius and also participate of the large anterior polytomy. D. laticollis is characterized by a synapomorphy, 29(2) hind angles of pronotum with apex inwards, and a homoplasy, 61(2) aedeagus narrow and long. It is the sistergroup of ((Cyathodera (Trielasmus varians (Paraloboderus glaber ((Loboederus appendiculatus) (Proloboderus crassipes)))))). The number of species examined is insufficient to propose new genera, considering the large number of species included in the genus at moment.

Dipropus brasilianus (Germar, 1824)

(Figs. 19, 72, 221, 261, 287, 324, 348, 410, 411).

Elater brasilianus Germar, 1824: 55.

Dipropus brasilianus; Germar, 1839: 217.

Ischiodontus brasilianus; Candèze, 1859: 105; 1891: 61 (cat.); Schenkling, 1925: 89 (cat.); Blackwelder, 1944: 299 (cat.).

Length:11.5-12.5 mm. General integument reddish-brown; legs and antennae clearer. Pubescence grayish, long, thin and moderately dense. Frons carinate, longer than wide; slightly concave medioanteriorly; anterior margin slightly rounded, almost straight, prominent, surpassing nasal; punctuation coarse and dense. Nasal high, slightly wider than long. Antennae (Fig. 19) with 11 antennomeres; in male 4 antennomeres longer than hind angles of pronotum; serrate; scape shorter than eye; $2^{\text {nd }}$ antennomere globular, $3^{\text {rd }}$ triangular, shorter than $4^{\text {th }}$, last narrowed at apex. Labrum (Fig. 72) subrectangular and setous. Mandibles wide with one apical and one subapical tooth; penicillus formed by short setae disposed in whole mesal area; molar area absent; dorsal region with carina and moderately long setae. Maxillae: galea with thick and spatulate setae; last palpomere securiform. Labium: prementum with setae in front of palpi; postmentum with 2 long setae and several shorter. Pronotum (Fig. 221) slightly convex, grooved longitudinal medially near base; wider than long, slightly narrowed to apex; lateral margins incompletely carinate; anterior margin straight; hind angles slightly divergent and carinate near lateral margin; median basal tubercle flat; punctuation moderately coarse and dense, sparser near base. Prosternal channel long. Prosternal spine with apex narrowed and rounded. Borders of mesosternal cavity declivous. Metacoxal plate (Fig. 261) strongly narrowed laterally; free margin with well developed tooth. Tibial spurs short; tarsomeres 2-3 lamellate beneath. Scutellum subtriangular. Elytra convex, narrowed on distal half; striae punctuated and grooved; interstices equal and slightly convex.

Male. Tergite 8 elongate, slightly narrowed apicad; with setae near middle and near margins; clothed with microtrichiae. Sternite 8 (Fig. 287) transverse, narrowed on distal third; anterior margin strongly notched at middle; anterior angles prominent and rounded; a band of setae near anterior and lateral margins. Sternite 9 (Fig. 324): apex gradually narrowed; distal half setous. Tergite 9 (Fig. 348) moderately notched at middle; punctuate with some setae near angles; tergite 10 longer than 9, with anterior margin rounded; setous near apex. Aedeagus (Figs. 410, 411) elongate; basal piece shorter than parameres; parameres fused ventrally; median lobe slightly narrowed to apex; slightly longer than parameres; parameres with apex securiform, rounded laterally.

Material examined. BRAZIL. São Paulo: São Paulo (Ipiranga), 1 ex. (MZSP); Monte Alegre (Faz. Sta. Maria), 1 ex. (MZSP).

Dipropus factuellus (Candèze, 1859)

(Figs. 20, 315, 349, 412, 413, 479).

Ischiodontus factuellus Candèze, 1859: 118; 1891: 62 (cat.); Schenkling, 1925: 90 (cat.); Blackwelder, 1944: 299 (cat.).

Length: 8.5-10.0 mm. General integument yellowishbrown. Pubescence yellowish, long and dense. Frons carinate, longer than wide; slightly concave medioanteriorly; anterior margin slightly rounded, almost straight, prominent, surpassing nasal; punctuation coarse and dense. Nasal high, slightly wider than long. Antennae (Fig. 20) with 11 antennomeres; in male 3.2 antennomeres longer than hind angles of pronotum; slightly serrate; scape shorter than eye; $2^{\text {nd }}$ antennomere globular, $3^{\text {rd }}$ triangular elongate, shorter than $4^{\text {th }}$, last narrowed at apex. Labrum subrectangular and setous, with anterior margin rounded. Mandibles wide with one apical and one subapical tooth; penicillus formed by short setae disposed in whole mesal area; molar area absent; dorsal region with carina and moderately long setae. Maxillae: galea with spatulate setae; last palpomere securiform. Labium: prementum with setae in front of palpi; postmentum with 2 long setae and several shorter. Pronotum slightly convex; wider than long, slightly narrowed to apex; lateral margins incompletely carinate; anterior margin almost straight; hind angles slightly divergent and carinate near lateral margin; median basal tubercle flat; punctuation moderately coarse and dense, sparser near base. Prosternal channel long. Prosternal spine with apex narrowed and rounded. Borders of mesosternal cavity declivous. Metacoxal plate strongly narrowed laterally; free margin with well developed tooth. Tibial spurs short; tarsomeres 2-3 lamellate beneath. Scutellum subtriangular elongate. Elytra convex, narrowed on distal half; striae deeply punctuated; interstices equal and flat.

Male. Tergite 8 (Fig. 315) wider than long, slightly narrowed apicad; with setae distributed on almost whole surface; clothed with microtrichiae. Sternite 8 transverse, narrowed on distal third; anterior margin strongly notched at middle; anterior angles prominent and rounded; a band of setae near anterior and lateral margins. Sternite 9: apex gradually narrowed; distal half setous. Tergite 9 (Fig. 349) moderately notched at middle; punctuate with some setae near angles; tergite 10 longer than 9, punctuate and setous. Aedeagus (Figs. 412,413 ) short and wide; basal piece longer than parameres; parameres fused ventrally; median lobe slightly narrowed to apex, with lateral margins sinuous; much longer than 


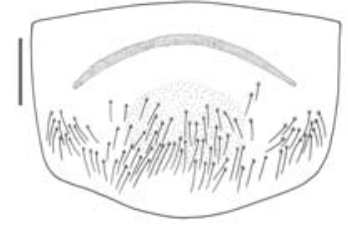

293

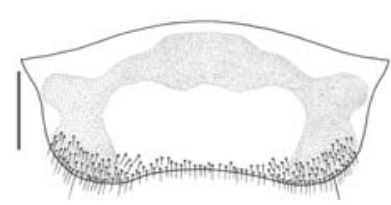

297

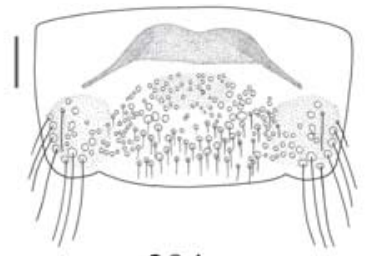

294

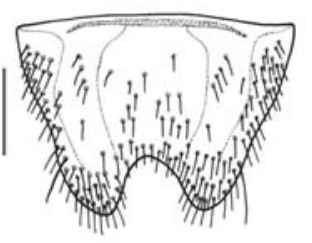

295

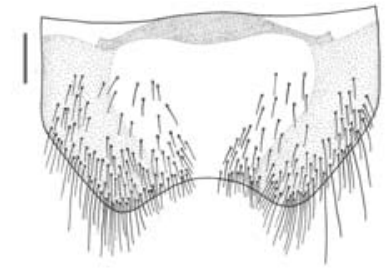

296

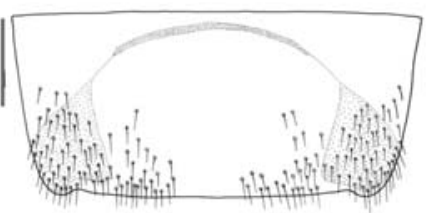

301

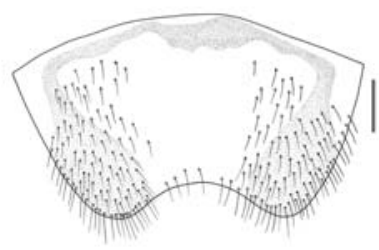

298

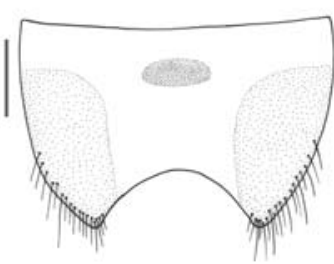

299

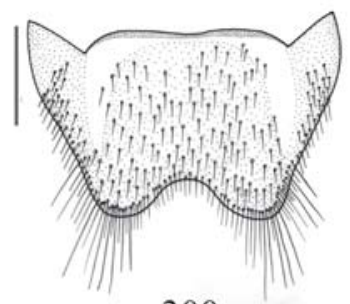

300

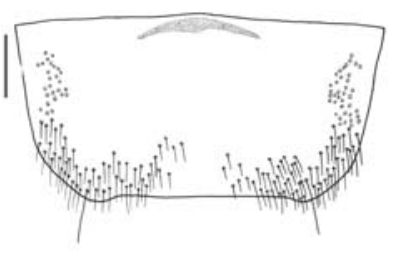

304

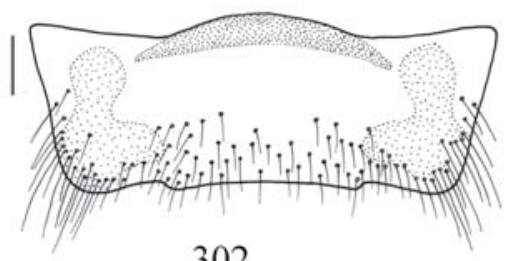

302

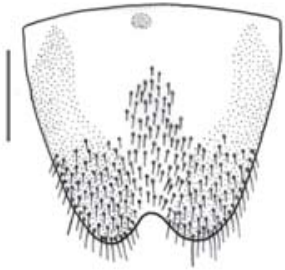

305

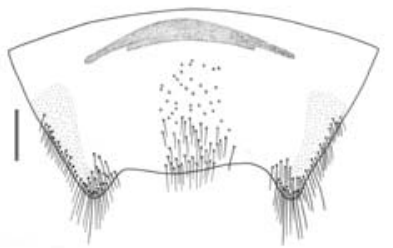

309

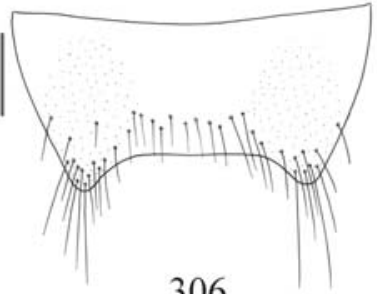

306

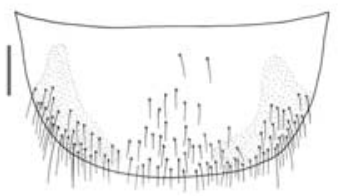

310

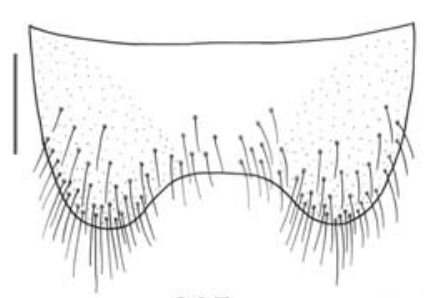

307

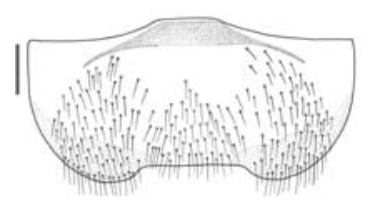

308

Figs. 293-311. Sternite 8 of male: 293, Heterocrepidius gilvellus; 294, Heterocrepidius ventralis; 295, Loboederus appendiculatus; 296, Melanotus spernendus; 297, Olophoeus gibbus; 298, Ovipalpus pubescens; 299, Physorhinus xanthocephalus; 300, Proloboderus crassipes; 301, Propsephus beniensis; 302, Pseudolophoeus guineensis; 303, Rhinopsephus apicalis; 304, Sephilus formosanus; 305, Sephilus frontalis, 306, Singhalenus gibbus; 307, Singhalenus taprobanicus; 308, Sphenomerus antennalis; 309, Sphenomerus brunneus; 310, Spilus nitidus; 311, Stenocrepidius simoni. Bars $=2 \mathrm{~mm}$, except figs. $293,304=1 \mathrm{~mm}$, figs. $295,299,301,305=0.5 \mathrm{~mm}$, fig. $297=5 \mathrm{~mm}$. 
parameres; parameres with apex securiform, narrow.

Female. Tergite 8 transverse, subtriangular; setae at middle and near apex, marginal longer. Sternite 8 (Fig. 479) elongate, narrowed on distal half; partially clothed with short setae; spiculum gastrale 4 times sternite length. Ovipositor with stylus; bursa copulatrix without spines or sclerotized pieces.

Material examined. ARGENTINA. 8 exs. (MZSP). Prov. Buenos Aires, 4 exs (MNHN). Chaco and Santiago del Estero Provinces: Rio Salado, 1 ex. (MZSP), 22 exs (MNHN). Missiones Province, 1 ex. (MZSP). PARAGUAY. 2 exs (MNHN).

Dipropus laticollis (Eschscholtz, 1829)

(Figs. 21, 73, 196, 222, 288, 325, 350, 414, 415,480).

Dicrepidius laticollis Eschscholtz, 1829: 31.

Dipropus laticollis; Germar, 1839: 216.

Anoplischius laticollis; Candèze, 1859: 74; Steinheil, 1875: 115; Champion,

1895: 314; Schenkling, 1925: 79 (cat.); Blackwelder, 1944: 298 (cat.).

Length: 14-17 mm. General integument reddish-brown; antennae and legs clearer. Pubescence yellowish, fine, very long, sparse and bristle. Frons carinate, longer than wide; convex; anterior margin rounded, surpassing nasal; punctuation moderately coarse and sparse. Nasal wider than long. Antennae (Fig. 21) with 11 antennomeres; in male 4.2 antennomeres longer than hind angles of pronotum; subserrate in both sexes; scape shorter than eye; $2^{\text {nd }}$ antennomere globular, $3^{\text {rd }}$ triangular elongate, shorter than $4^{\text {th }}$, last narrowed at apex. Labrum (Fig. 73) semielliptical with long setae. Mandibles with one apical and one subapical tooth; penicillus formed by short setae disposed in whole mesal area; molar area well developed; dorsal region with carina and moderately long setae. Maxillae: galea with spatulate setae; last palpomere securiform. Labium: prementum with long setae in front of palpi; postmentum with two long setae and many moderately short. Pronotum (Fig. 222) wider than long, slightly convex; lateral margins carinate; anterior margin slightly prominent at middle; hind angles inwardly directed, with long carina; median basal tubercle indistinct; punctuation moderately coarse and sparse. Prosternal channel long. Prosternal spine (Fig. 196) curved, compressed laterally with subapical lobe. Borders of mesosternal cavity narrow and declivous. Metacoxal plate strongly narrowed laterally; free margin straight. Tibial spurs long; tarsomeres 1-3 lamellate beneath. Scutellum elongate, slightly narrowed to apex; distal margin rounded. Elytra convex, narrowed apicad; striae grooved at base, marked by weak moderately coarse punctuation; interstices flat.

Male. Tergite 8 elongate, gradually narrowed to apex; anterior margin rounded; punctuate and marginate by setae; translucent at base; clothed with microtrichiae. Sternite 8 (Fig. 288) elongate, slightly narrowed on distal half; anterior margin notched at middle; translucent in a basal U-shaped area; partially clothed by setae, longer near margins. Sternite 9 (Fig. 325): distal third abruptly narrow to apex; setous near apex. Tergite 9 (Fig. 350) slightly notched at middle, almost straight; a few setae near angles; tergite 10 narrow, longer than 9. Aedeagus (Figs. 414, 415) narrow and long; basal piece shorter than parameres; parameres fused ventrally; median lobe almost straight, narrowed at apex; much longer than parameres; apex of parameres spatuliform, slitted subapically.

Female. Tergite 8 elongate, narrowed to apex; basal third translucent; setae at apex, marginal longer. Sternite 8 (Fig. 480) elongate, narrowed apicad; partially clothed with short setae; spiculum gastrale 4.60 times sternite length. Ovipositor with stylus; bursa copulatrix without spines or sclerotized pieces.

Material examined. BRAZIL. Minas Gerais: Santa Bárbara (Serra do Caraça), 4 exs. MZSP); Vila Monte Verde, 16 exs. (MZSP). Rio de Janeiro: Petrópolis, 1 ex. (MNHN). Espírito Santo: ex-coll. Fleutiaux, 1 ex. (MNHN); Linhares, 12 exs. (MZSP). São Paulo: Alto da Serra, 1 ex. (MZSP); Alto da Serra (Estação Biológica de Paranapiacaba), 2 exs. (MZSP); Barueri, 6 exs. (MZSP); Itu (Faz. Pau d'Alho), 1 ex. (MZSP); Monte Alegre (Faz. Sta Maria), 2 exs. (MZSP); Osasco, 1 ex. (MZSP); Pindamonhangaba (Eugênio Lefrève), 3 exs. (MZSP); São Paulo (Santo Amaro), 1 ex. (MZSP). Paraná: Ponta Grossa, 1 ex. (MZSP).

\section{Dipropus pinguis (Candèze, 1859)}

(Figs. 22, 223, 262).

Ischiodontus pinguis Candèze, 1859: 103; 1891: 61 (cat.); Champion, 1895: 319; Schenkling, 1925: 91 (cat.); Blackwelder, 1944: 300 (cat.).

Length: $13.5 \mathrm{~mm}$. General integument reddish-dark-brown; legs and antennae clearer. Pubescence whitish, moderately long and moderately dense. Frons carinate, longer than wide; convex; anterior margin rounded and prominent, surpassing nasal; punctuation coarse and dense. Nasal wider than long. Antennae (Fig. 22) with 11 antennomeres; serrate; antennomeres 3-11 with longitudinal carina; scape as long as eye; $2^{\text {nd }}$ antennomere globular, $3^{\text {rd }}$ triangular elongate, slightly shorter than $4^{\text {th }}$, last narrowed at apex. Labrum semielliptical and setous. Pronotum (Fig. 223) strongly convex; wider than long, slightly narrowed to apex; lateral margins incompletely carinate; anterior margin U-shaped; hind angles backwardly directed and carinate; median basal tubercle flat; punctuation coarse and dense. Prosternal channel long. Prosternal spine with apex narrowed and rounded. Borders of mesosternal cavity narrow and declivous. Metacoxal plate (Fig. 262) slightly narrowed laterally; free margin with small tooth. Tibial spurs long; tarsomeres 2-3 lamellate beneath. Scutellum elongate with posterior margin rounded; anterior, lateral and posterior margins notched at middle. Elytra convex, narrowed on distal third; striae punctuate and grooved; interstices equal and convex.

Material examined. Without locality, 1 ex. (MNHN).

Dipropus schwarzi (Becker, 1961)

(Figs. 127, 128, 224, 289, 351, 416, 417).

Ischiodontus schwarzi Becker, 1961: 169.

Length: 8-9 $\mathrm{mm}$. General integument reddish-brown; antennae and legs clearer. Pubescence yellowish, long, moderately dense and bristle. Frons carinate, longer than wide; 


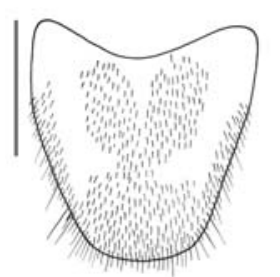

312

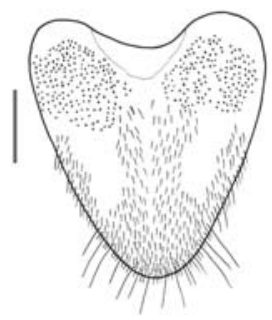

317

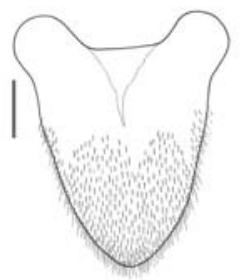

313

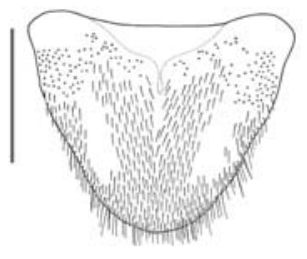

314

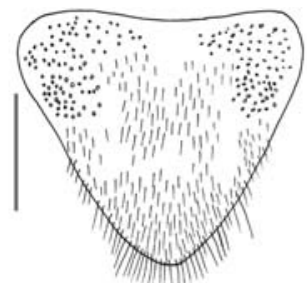

315

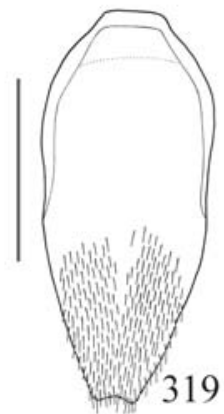

319
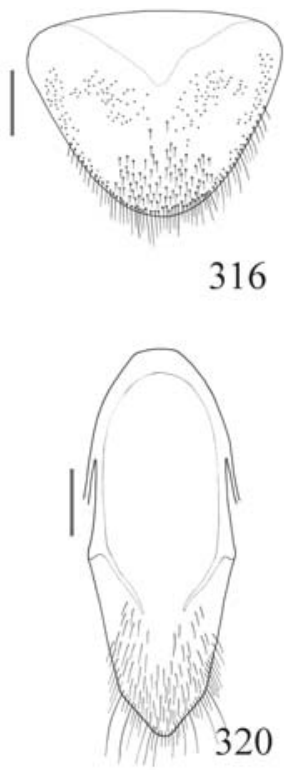

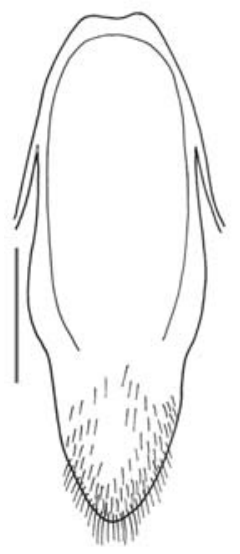

321

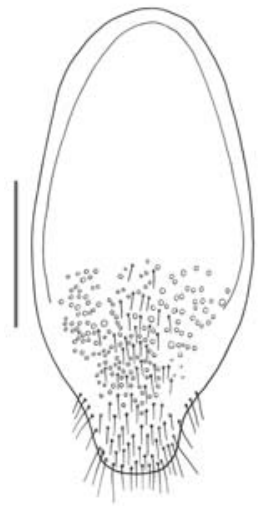

326

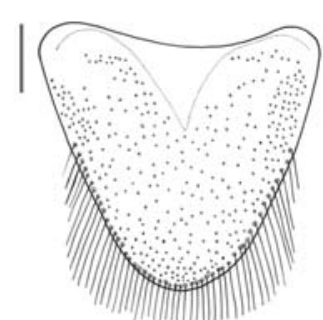

318

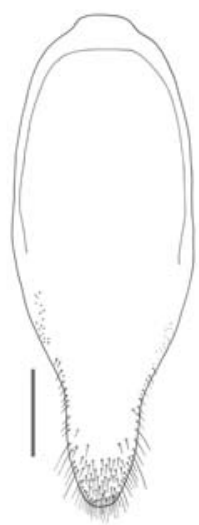

322

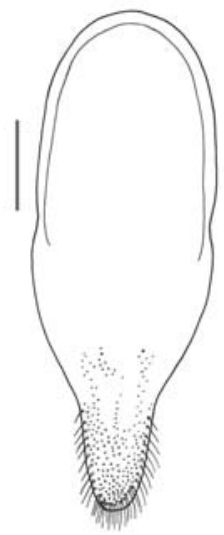

323

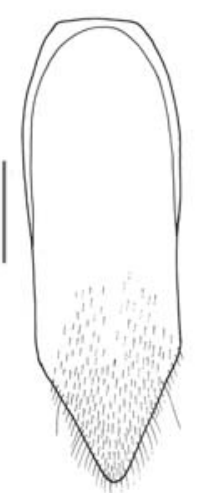

324

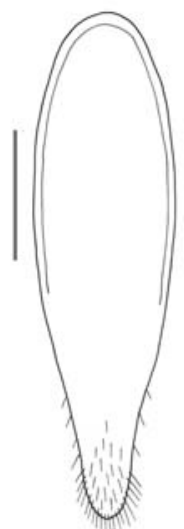

325

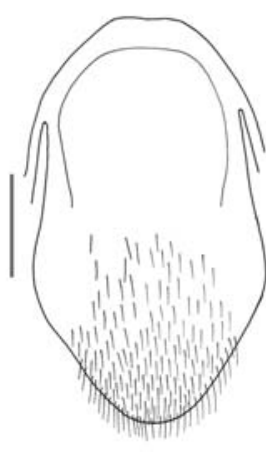

327

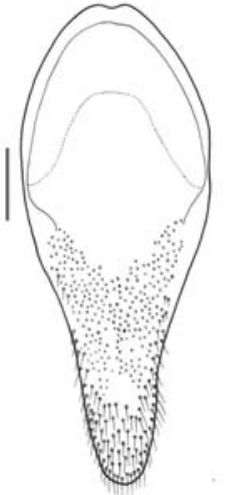

328

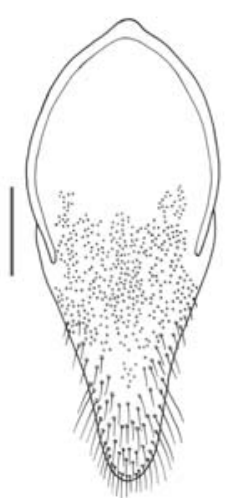

329

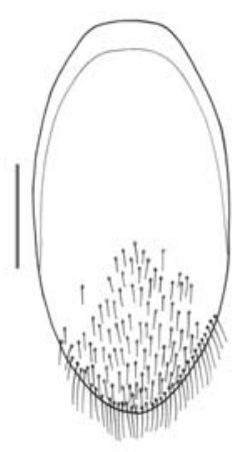

330

Figs. 312-330. Tergite 8 of male: 312, Achrestus flavocinctus; 313, Anoplischius haematopus; 314, Blauta cribraria; 315, Dipropus factuellus; 316, Lampropsephus cyaneus; 317, Pantolamprus mirabilis; 318, Proloboederus crassipes. Sternite 9 of male: 319, Blauta cribraria; 320 , Crepidius flabellifer; 321, Crepidius resectus; 322, Cyathodera lanugicollis; 323, Cyathodera longicornis; 324, Dipropus brasilianus; 325, Dipropus laticollis; 326, Heterocrepidius gilvellus; 327, Lampropsephus cyaneus; 328, Loboederus appendiculatus; 329, Proloboderus crassipes; 330, Sphenomerus antennalis. Bars $=5 \mathrm{~mm}$, except figs. $312,322,323=10 \mathrm{~mm}$, figs. $313,316-319,326=1 \mathrm{~mm}$, fig. $320=2 \mathrm{~mm}$, figs. $327-$ $329=0.5 \mathrm{~mm}$. 
convex and flat anteriorly; anterior margin straight, prominent, surpassing nasal; punctuation moderately coarse and dense. Nasal wider than long. Antennae with 11 antennomeres; in male 4.25 antennomeres longer than hind angles of pronotum; serrate; scape shorter than eye; $2^{\text {nd }}$ antennomere globular, $3^{\text {rd }}$ triangular elongate, as long as $4^{\text {th }}$ and same shape, last narrowed at apex. Labrum semielliptical with long setae. Mandibles (Figs. 127, 128) with one apical and one subapical tooth; penicillus formed by short setae disposed in whole mesal area; molar area well developed; dorsal region with carina and moderately long setae. Maxillae: galea with spatulate setae; last palpomere securiform. Labium: prementum with long setae in front of palpi; postmentum with two long setae and many moderately short. Pronotum (Fig. 224) wider than long, slightly narrowed anteriad; strongly convex; convexity decreasing basad; lateral margins carinate; anterior margin straight; hind angles backwardly directed and carinate; median basal tubercle indistinct; punctuation moderately coarse and sparse, sparser and smaller basad. Prosternal channel long. Prosternal spine with subapical lobe. Borders of mesosternal cavity narrow and declivous. Metacoxal plate strongly narrowed laterally; free margin with tooth. Tibial spurs long; tarsomeres 2-3 lamellate beneath. Scutellum pentagonal with posterior margin rounded. Elytra convex, narrowed apicad; striae coarsely punctuate and grooved; interstices equal and slightly convex.

Male. Tergite 8 elongate, gradually narrowed to apex; anterior margin rounded; punctuate and marginate by setae; translucent in a triangular area at base; clothed with microtrichiae. Sternite 8 (Fig. 289) transverse strongly narrowed on distal half; anterior half trapezoidal; translucent in a basal U-shaped area; densely setous near margins. Sternite 9: distal third gradually narrow to apex; punctuate on distal half and setous near apex. Tergite 9 (Fig. 351) strongly notched at middle; punctuate with few setae near angles; tergite 10 slightly shorter than 9 , punctuate with setae on distal half. Aedeagus (Figs. 416, 417) elongate; basal piece shorter than parameres; parameres fused ventrally; median lobe almost straight, constricted at apex and near base; slightly longer than parameres; apex of parameres securiform preceded by lateral tooth.

Material examined. UNITED STATES OF AMERICA. Florida. Highland co., 4 exs (MZSP).

\section{Elius Candèze, 1859}

Elius Candèze, 1859: 9, 45; 1891: 56 (cat.); Fleutiaux, 1905: 320; Schwarz, 1906: 60, 72; Schenkling, 1925: 84 (cat.); Fleutiaux, 1928: 105 (cat.).

Sphenomerus Fleutiaux, 1918 (non Candèze)

Aelius Sharp, 1889: 132

Type-species: Elius prionocerus Candèze, 1859, designated by monotypy.

Candèze (1859) erected Elius to one species, E. prionocerus, from Madras. Candèze (1891) catalogued 8 species to this genus.

Schwarz (1906) included 11 species in the genus.

Schenkling (1925) catalogued 11 species to this genus.
Fleutiaux (1928) described 4 new species, considered Sphenomerus mouhoti Fleutiaux, 1918 (non Candèze) as synonym of Elius birmanicus and gave a new name to Sphenomerus mouhoti Fleutiaux, 1918 (non Candèze), Elius correctus. He also presented an identification key to 6 species and a note with some retifications and observations about $E$. stuppens Candèze, 1893 and $E$. dilatatus Candèze, 1878.

The genus Elius is formed by 16 species: E. alveolarius Candèze, 1878, E. angusticollis Fleutiaux, 1928, E. annamensis Fleutiaux, 1928, E. birmanicus Candèze, 1893 (=Sphenomerus mouhoti Fleutiaux, 1918), E. candezei Fleutiaux, 1928, E. correctus Fleutiaux, 1928 (=Sphenomerus mouhoti Fleutiaux, 1918), E. dilatatus Candèze, 1878, E. elegans Candèze, 1880, E. insularis Candèze, 1889, E. prionocerus Candèze, 1859, E. robustus Fleutiaux, 1928, E. sericeus Candèze, 1893, E. serraticornis Kirsch, 1875, E. stuppeus Candèze, 1893, E. umbilicatus Candèze, 1865, E. ventralis Candèze, 1888. It is recorded from India, Burma, Laos, Thailand, Malaysia, Singapore, Borneo.

The Elius species included in this analysis form a monophyletic group, characterized by homoplasies, 3(2) anterior margin of frons strongly prominent, 56(1) sternite 8 of male gradually narrowed to apex and 66(1) median lobe moderately longer than parameres. It is the sister-group of ((Stenocrepidius simoni)(Heterocrepidius)).

Elius birmanicus Candèze, 1893

(Figs. 23, 74, 225, 263, 290, 352, 418, 419).

Elius birmanicus Candèze, 1893: 173; Schenkling, 1925: 84 (cat.).

Length: 24.5-25.0 mm. General integument reddish-brown. Pubescence yellowish, long and dense. Frons carinate, longer than wide; convex; anterior margin slightly rounded, almost straight, prominent surpassing nasal; punctuation moderately coarse and dense. Nasal very high, slightly wider than long, coarsely punctuate. Antennae (Fig. 23) with 11 antennomeres; densely pubescent; in male 2.7 antennomeres longer than hind angles of pronotum; strongly serrate; scape shorter than eye; $2^{\text {nd }}$ antennomere globular, $3^{\text {rd }}$ triangular and prominent laterally, shorter than $4^{\text {th }}$, last narrowed at apex. Labrum (Fig. 74) semicircular and setous. Mandibles narrow with one apical and one subapical tooth; penicillus formed by short setae disposed in whole mesal area; molar area absent; dorsal region with carina and moderately long setae. Maxillae: galea with simple setae; last palpomere widened to apex. Labium: prementum with setae in front of palpi; postmentum with two long setae and many moderately short. Pronotum (Fig. 225) convex, slightly wider than long, slightly narrowed to apex; lateral margins straight and incompletely carinate; anterior margin straight; hind angles backwardly directed and carinate; median basal tubercle flat preceded by carina; punctuation moderately coarse and very dense. Prosternal channel long. Prosternal spine flat with apex narrowed and rounded. Borders of mesosternal cavity narrow and declivous. Metacoxal plate (Fig. 263) strongly narrowed laterally; free margin with small 


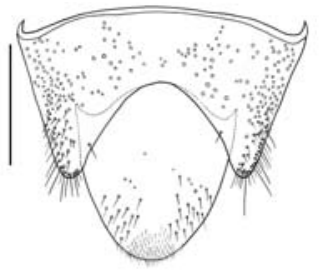

331

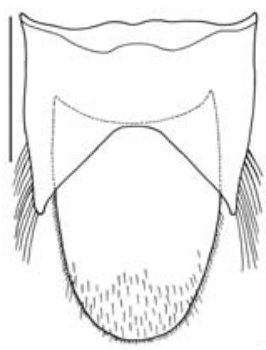

335

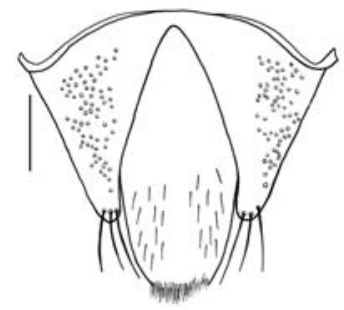

339

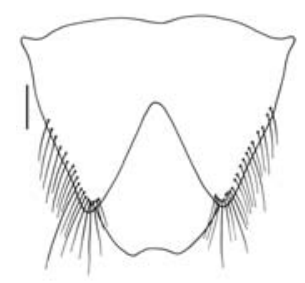

343

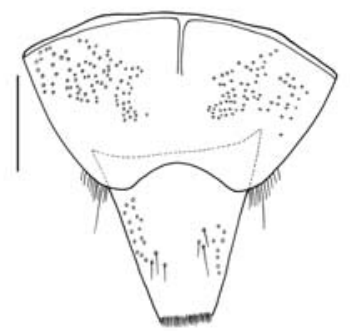

347
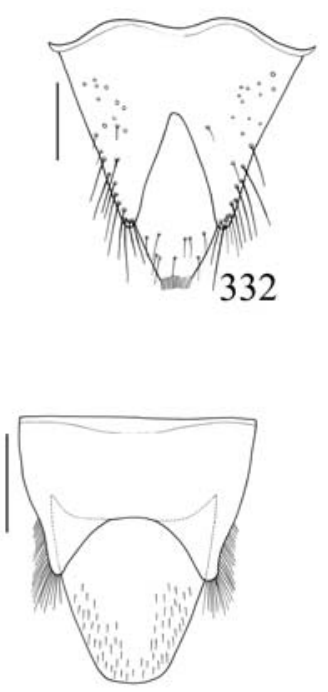

336

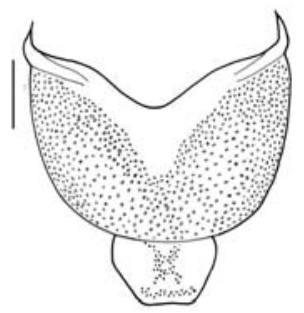

340

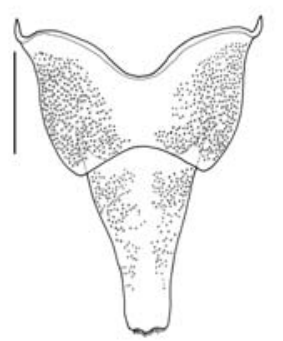

344

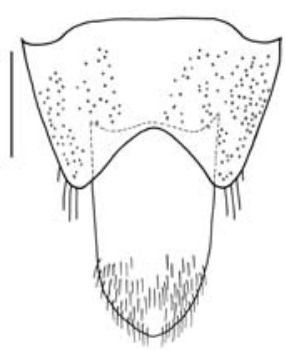

348
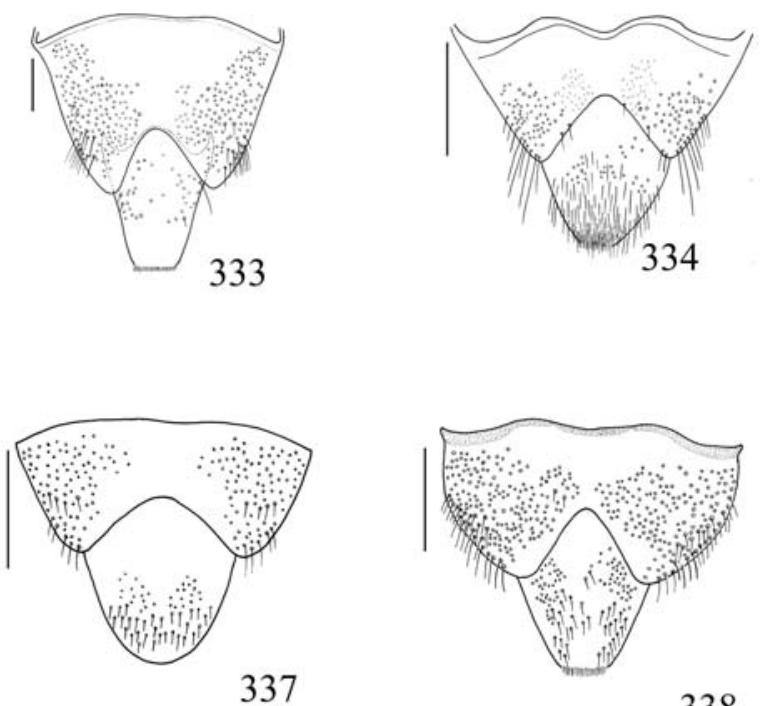

338

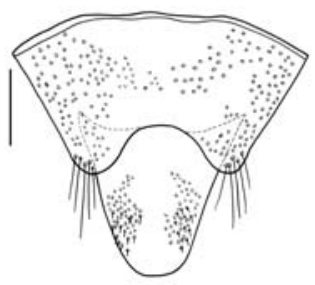

341

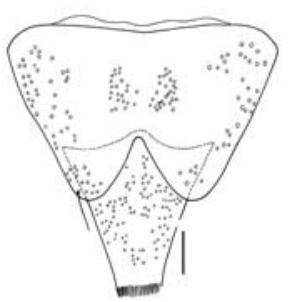

342

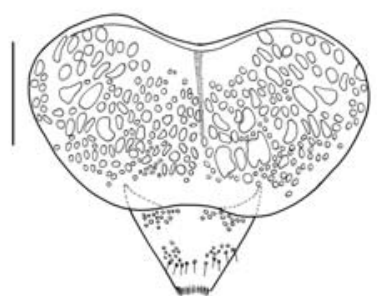

346

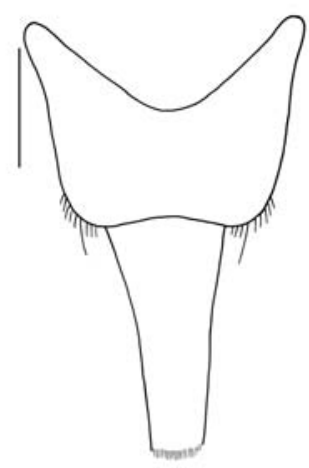

350

Figs. 331-350. Tergites 9-10 of male: 331, Achrestus flavocinctus; 332, Adiaphorus gracilis; 333, Adiaphorus ponticerianus; 334, Ampedus sanguineus; 335, Anoplischius bicarinatus; 336, Anoplischius haematopus; 337, Atractosomus flavescens; 338, Blauta cribraria; 339, Calopsephus apicalis; 340, Chalcolepidius zonatus; 341, Crepidius flabellifer; 342, Crepidius resectus; 343, Ctenicera silvatica; 344, Cyathodera lanugicollis; 345, Cyathodera longicornis; 346, Dayakus angularis; 347, Dicrepidius ramicornis; 348, Dipropus brasilianus; 349, Dipropus factuellus; 350, Dipropus laticollis. Bars $=2 \mathrm{~mm}$, except figs. 331, 334, 346, $350=5 \mathrm{~mm}$, figs. 335, 336, 338, 340, 344, 347=1 mm, figs. 341, 352=0.5 mm, fig. $349=10 \mathrm{~mm}$. 
lobe. Tibial spurs long; tarsomeres 1-3 lamellate beneath on legs anterior and median and 2-3 on posterior legs. Scutellum subpentagonal with distal margin rounded. Elytra convex, narrowed on distal third; striae punctuated and grooved; interstices equal and slightly convex.

Male. Tergite 8 subtriangular, setous on distal 2/3; clothed with microtrichiae. Sternite 8 (Fig. 290) transverse, slightly narrowed on distal half; anterior margin strongly notched at middle; translucent at middle, partially clothed by setae. Sternite 9: distal half gradually narrowed to apex; punctuate near middle and setous near apex. Tergite 9 (Fig. 352) strongly notched at middle; punctuate laterally; setae laterally near apex; tergite 10 longer than 9 , punctuate and with setae near apex. Aedeagus (Figs. 418, 419) elongate; basal piece shorter than parameres; parameres fused ventrally; median lobe almost straight, constricted at apex; slightly longer than parameres; parameres with lateral tooth near apex.

Material examined. LAOS. Xieng Khouang Province: Mt. Mekong, 4 exs (MNHN); rive Siamoise, 2 exs. (MNHN). Luang Prabang, 1 ex. (MNHN). VIETNAM. Annam, 1 ex. (MNHN). Cochinchina, Mont Chaudoc, 1 ex. (MNHN)

Elius dilatatus Candèze, 1878

(Figs. 24, 75, 197, 226, 291, 353, 420, 421).

Elius prionocerus Candèze, 1878: 11; 1891: 56 (cat.); Schenkling, 1925: 84 (cat.).

Length: 16-17 mm. General integument reddish-brown. Pubescence yellowish, long and dense. Frons carinate, longer than wide; convex; anterior margin roundly prominent surpassing nasal; with longitudinal median carina at base; punctuation coarse and dense. Nasal very high, slightly wider than long, coarsely punctuate. Antennae (Fig. 24) with 11 antennomeres; densely pubescent; in male 2.2 antennomeres longer than hind angles of pronotum; serrate, stronger in male; scape shorter than eye; $2^{\text {nd }}$ antennomere globular, $3^{\text {rd }}$ triangular elongate, shorter than $4^{\text {th }}$, last narrowed at apex. Labrum (Fig. 75) narrow, semi-elliptical. Mandibles narrow with one apical and one subapical tooth; dorsal region with carina and moderately long setae. Last maxillar palpomere widened to apex. Pronotum (Fig. 226) slightly wider than long, slightly narrowed to apex; moderately convex; lateral margins straight and carinate; anterior margin lightly prominent at middle; hind angles long, backwardly directed and carinate; median basal tubercle flat; punctuation coarse and very dense. Prosternal channel long. Prosternal spine (Fig. 197) flat with apex narrowed and rounded. Borders of mesosternal cavity narrow and declivous. Metacoxal plate strongly narrowed laterally; free margin with small lobe. Tibial spurs long; tarsomeres 1-3 lamellate beneath on legs anterior and median and 2-3 on posterior legs. Scutellum subpentagonal with distal margin rounded. Elytra convex, narrowed on distal third; striae punctuated and grooved; interstices equal and slightly convex.

Male. Tergite 8 subtriangular, almost completely setous; clothed with microtrichiae. Sternite 8 (Fig. 291) transverse, narrowed apicad; anterior margin slightly notched at middle; translucent at middle, partially clothed by setae. Sternite 9 : distal half gradually narrowed to apex; punctuate near middle and setous near apex. Tergite 9 (Fig. 353) moderately notched at middle; punctuate; a few setae laterally near apex; tergite 10 longer than 9, punctuate. Aedeagus (Figs. 420, 421) elongate; basal piece shorter than parameres; parameres fused ventrally; median lobe almost straight, constricted at apex; slightly longer than parameres; parameres with lateral tooth near apex.

Material examined. INDIA. Côte de Malabar, 1 ex. (MNHN). REPUBLIC OF SINGAPORE. 3 exs (MNHN). MALAYSIA. Selangor, Bukit Kutu, 1 ex. (MNHN).

\section{Heterocrepidius Guérin-Méneville, 1838}

Heterocrepidius Guérin-Méneville, 1838: 23; Lacordaire, 1857: 167, 170; Candèze, 1859: 9, 31; 1891: 55 (cat.); Champion, 1895: 297; Schwarz, 1906: 60, 64; Schenkling, 1925: 77 (cat.); Blackwelder, 1944: 297 (cat.). Heteropus Germar, 1839: 217

Type-species: Heterocrepidius ventralis Guérin-Méneville, 1838, designated by Hyslop (1921) by monotypy.

Guérin-Méneville (1838) erected Heterocrepidius to $H$. ventralis from Peru. When he described the tarsi, lamellate under $2^{\text {nd }}$ and $3^{\text {rd }}$ tarsomeres of anterior and median tarsi and only at $3^{\text {rd }}$ at posterior tarsi, he stated that "... ce qui pourrait autoriser à former avec cet insecte une coupe générique liant les Monocrepidius aux Dicrepidius, coupe que nous proposerions de désigner sous le nom d Heterocrepidius".

Lacordaire (1857) redescribed the genus and stated about the tarsal lamellae. According to him, several genera were established based on the number of tarsal lamellae. The name used by Guérin-Méneville (l. c.), Heterocrepidius, is related to different number of lamellae under posterior tarsi. In fact, this genus presents tarsomeres 1-3 lamellate at anterior and median legs and tarsomeres 2-3 at posterior leg.

Candèze (1859) redescribed the genus Heterocrepidius and presented an identification key for 11 species, from which, 8 new species and 2 removed from Heteropus, besides the typespecies. The majority of these species are from Brazil. According to him, they look-like Physodactylus Fischer, 1823, also with legs dilated.

Candèze (1891) catalogued 15 species to Heterocrepidius and considered Heteropus Germar as synonym.

Fleutiaux (1892) erected Dactylophysus (Physodactylini, Elaterinae), to Heterocrepidius mendax Candèze, 1859, considering "Heterocrepidius Candèze, 1859 (nec Guér.)" as synonym of this genus.

The genus was composed by 16 species, from which 13 are from South America, one from Mexico and two from South Africa. Champion (1895) transferred the species from South Africa to Anoplischius and described H. megalops, from Costa Rica.

Schwarz (1906) included 22 species in the genus.

Schenkling (1925) catalogued 23 species to this genus.

Blackwelder (1944) catalogued 18 species to this genus. 


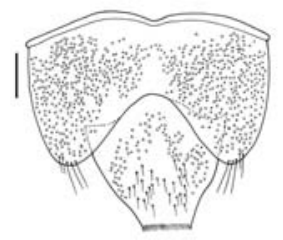

351

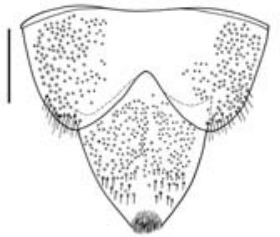

352

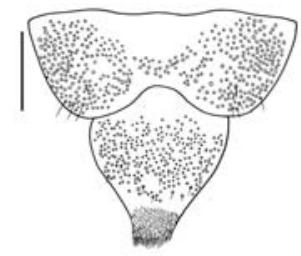

353

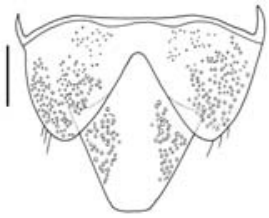

354

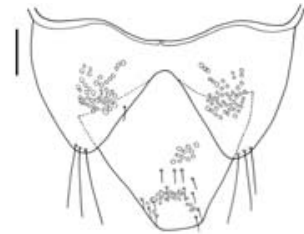

355

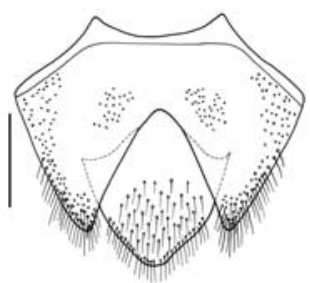

356

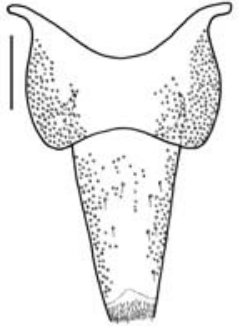

357

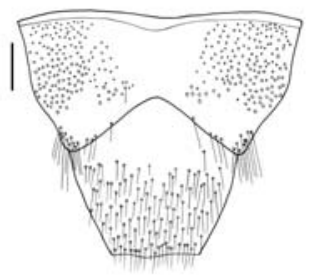

358

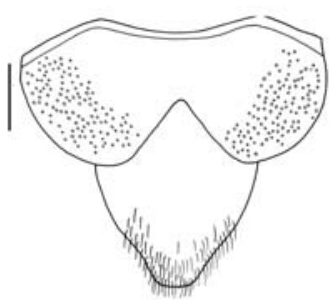

359

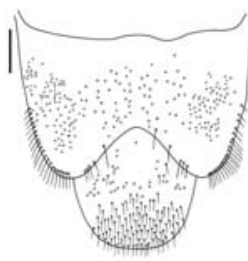

360

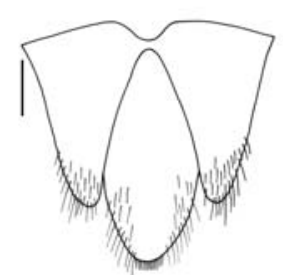

361

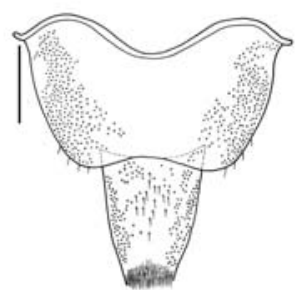

362

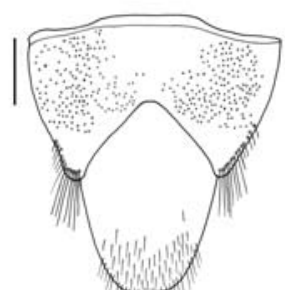

363

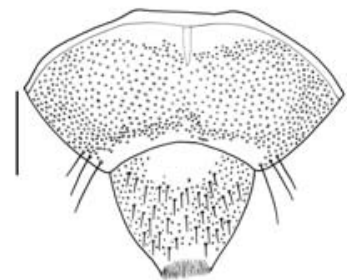

364

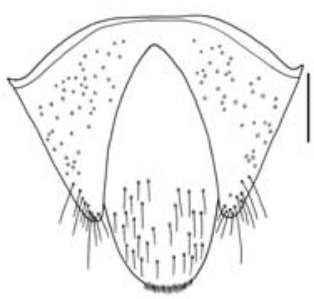

365

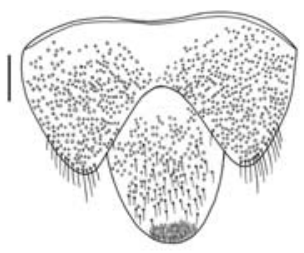

366

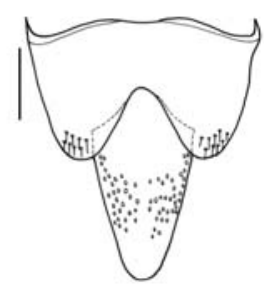

367

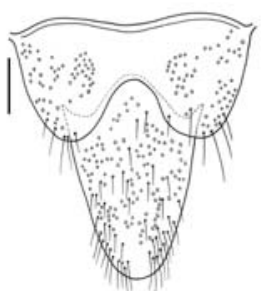

368

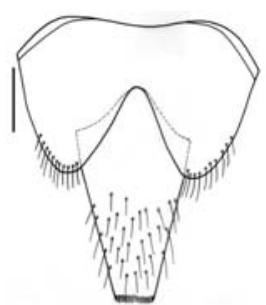

369

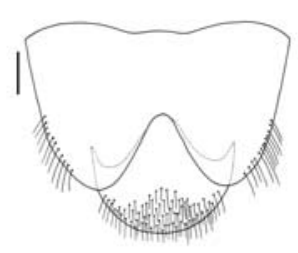

370

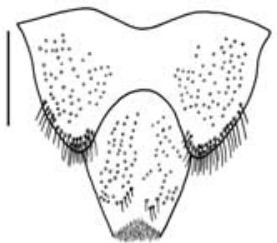

371

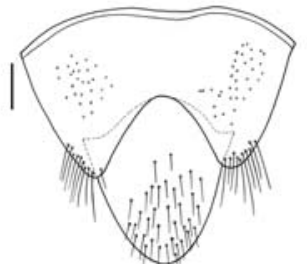

372

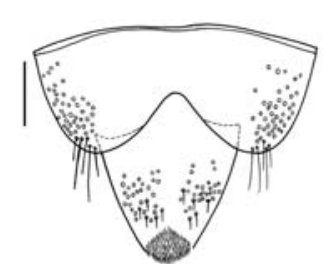

373

Figs 351-373. Tergites 9-10 of male: 351, Dipropus schwarzi; 352, Elius birmanicus; 353, Elius dilatatus; 354, Heterocrepidius gilvellus; 355, Heterocrepidius ventralis; 356, Lampropsephus cyaneus; 357, Loboederus appendiculatus; 358, Melanotus spernendus; 359, Olophoeus gibbus; 360, Ovipalpus pubescens; 361, Physorhinus xanthocephalus; 362, Proloboderus crassipes; 363, Propsephus beniensis; 364, Pseudolophoeus guineensis; 365, Rhinopsephus apicalis; 366, Sephilus formosanus; 367, Sephilus frontalis; 368, Singhalenus gibbus; 369, Singhalenus taprobanicus, 370, Sphenomerus antennalis; 371, Sphenomerus brunneus; 372, Spilus nitidus; 373, Stenocrepidius simoni. Bars = 2 mm, except figs. $352-354,356,362,363,367=0.5 \mathrm{~mm}$, fig. $357=1 \mathrm{~mm}$, figs. $359,364,365,371=5 \mathrm{~mm}$. 
The genus Heterocrepidius is formed by 25 species: $H$. aenescens Candèze, 1859, $H$. afer Candèze, 1889, $H$. castanopterus Candèze, 1859, H. columbicus Steinh., 1875, $H$. contractus Candèze, 1896, H. corvinus Candèze, 1896, $H$. crocipes (Germar, 1824), H. depressus Candèze, 1859, $H$. ferrugineus Lucas, 1857, $\mathrm{H}$. gilvellus Candèze, $1859, \mathrm{H}$. glis Candèze, 1859, H. granulatus Candèze, 1859, H. indicus Candèze, 1893, H. insularis Candèze, 1894, H. majusculus Candèze, 1896, H. marginatus Candèze, 1896, H. megalops Champion, 1895, H. minor Schwarz, 1906, H. modestus Schwarz, 1906, H. morio Candèze, 1896, H. picipes (Germar, 1839), H. puberulus Boh., 1858, H. rufus Steinheil, 1873, H. tibialis Candèze, $1859, H$. ventralis Guérin, 1838 . It is recorded from Central America (Costa Rica), South America (Colombia, Brazil, Ecuador, Peru, Argentina, Uruguay), India and Indonesia (Sumatra).

The Heterocrepidius species included in this analysis form a monophyletic group, characterized by sinapomorphies, 38(1) femur widened and 68(2) apex of median lobe widely rounded, and by homoplasies, 31(2) carina of hind angles of pronotum weak, 37(2) free margin of metacoxal plate with very developed lobe, 59(1) median region of tergite 9 of male very narrow and 62(2) basal piece longer than parameres. It is the sister-group of Stenocrepidius simoni.

Heterocrepidius gilvellus Candèze, 1859

(Figs. 25, 76, 129, 130, 165, 179, 228, 264, 293, 326, 354, 422, 423).

Heterocrepidius gilvellus Candèze, 1859: 34; Schenkling, 1925: 77 (cat.); Blackwelder, 1944: 297 (cat.).

Length: 10.0-10.5 mm. General integument reddish-brown clear. Pubescence yellowish-white, long and dense. Frons carinate, longer than wide; concave medioanteriorly; anterior margin roundly prominent, surpassing nasal; punctuation moderately coarse and dense. Nasal short, wider than long. Antennae (Fig. 25) with 11 antennomeres; in male 2 antennomeres longer than hind angles of pronotum; subserrate; scape shorter than eye; $2^{\text {nd }}$ antennomere globular, $3^{\text {rd }}$ cylindrical, elongate, shorter than $4^{\text {th }}$, last narrowed at apex. Labrum (Fig. 76) narrow and setous. Mandibles (Figs. 129, 130) elongate with subapical small tooth; penicillus formed by short setae disposed in whole mesal area; dorsal region with carina and moderately long setae. Maxillae (Fig. 165): galea with simple setae; last palpomere elliptical. Labium (Fig. 179): prementum with long setae in front of palpi; postmentum with some long setae and many moderately short. Pronotum (Fig. 228) convex, wider than long, slightly narrowed to apex; lateral margins straight and incompletely carinate; anterior margin straight; hind angles backwardly directed and weakly carinate; median basal tubercle indistinct; punctuation moderately coarse and very dense. Prosternal channel absent. Prosternal spine with subapical lobe. Borders of mesosternal cavity narrow and declivous. Metacoxal plate (Fig. 264) very wide, strongly narrowed laterally; free margin with lobe. Femur dilatate; tibial spurs long; tarsomeres 1-3 lamellate at anterior and median legs and tarsomere 3 at posterior leg. Scutellum subtriangular elongate. Elytra convex, narrowed on distal fourth; striae punctuated and grooved; interstices equal and slightly convex.

Male. Tergite 8 wider than long, narrowed apicad; anterior margin straight; setae near lateral and anterior margins; clothed with microtrichiae. Sternite 8 (Fig. 293) transverse, with anterior margin slightly prominent at middle; anterior angles rounded; translucent with a narrow transversal basal sclerite; a band of setae near anterior margin. Sternite 9 (Fig. 326): apex abruptly narrowed; distal half punctuate and setous. Tergite 9 (Fig. 354) strongly notched at middle; punctuate laterally, with some setae near angles; tergite 10 longer than 9, punctuate laterally. Aedeagus (Figs. 422, 423) elongate; basal piece longer than parameres; parameres fused ventrally; median lobe wide, almost straight, slightly narrowed near middle with apex rounded; strongly longer than parameres; parameres with apex securiform.

Material examined. Without locality: 1 ex. (MNHN). BRAZIL. Excoll. Chevrolat, ex-coll. Fleutiaux, 1 ex. (MNHN).

Heterocrepidius ventralis Guérin-Méneville, 1838

(Figs. 26, 77, 131, 132, 229, 265, 294, 355, 424, 425).

Heterocrepidius ventralis Guérin-Méneville, 1838: 23; Candèze, 1859: 36; Schenkling, 1925: 77 (cat.); Blackwelder, 1944: 297 (cat.).

Length: 8.5-9.0 mm. General integument reddish darkbrown. Pubescence whitish, moderately long and dense. Frons carinate, longer than wide; slightly concave medioanteriorly; anterior margin roundly prominent, surpassing nasal; punctuation moderately coarse and very dense. Nasal short, wider than long. Antennae (Fig. 26) with 11 antennomeres; in male 2 antennomeres longer than hind angles of pronotum; subserrate; scape shorter than eye; $2^{\text {nd }}$ antennomere globular, $3^{\text {rd }}$ cylindrical, elongate, shorter than $4^{\text {th }}$, last narrowed at apex. Labrum (Fig.77) semielliptical and setous. Mandibles (Figs. 131, 132) narrow with one apical and one subapical small tooth; penicillus formed by short setae disposed in whole mesal area; molar area absent; dorsal region with carina and moderadely long setae. Maxillae: galea with simple setae; last palpomere elliptical. Labium: prementum with long setae in front of palpi; postmentum with some long setae and many moderately short. Pronotum (Fig. 229) convex, wider than long, slightly narrowed to apex; lateral margins straight and incompletely carinate; anterior margin slightly prominent at middle; hind angles slightly divergent and weakly carinate; median basal tubercle indistinct; punctuation moderately coarse and very dense. Prosternal channel absent. Prosternal spine with subapical lobe. Borders of mesosternal cavity narrow and declivous. Metacoxal plate (Fig. 265) strongly narrowed laterally; free margin with lobe. Femur dilatate; tibial spurs long; tarsomeres 1-3 lamellate at anterior and median legs and tarsomeres 2-3 at posterior legs. Scutellum subpentagonal elongate. Elytra convex, narrowed on distal fourth; striae punctuated and grooved; interstices equal and slightly convex. 


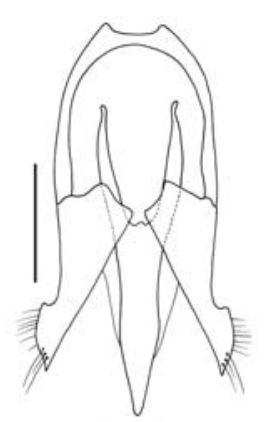

374

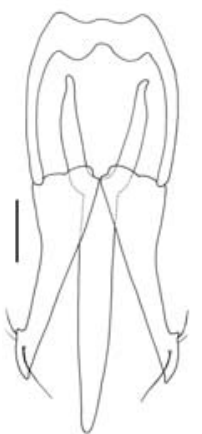

380

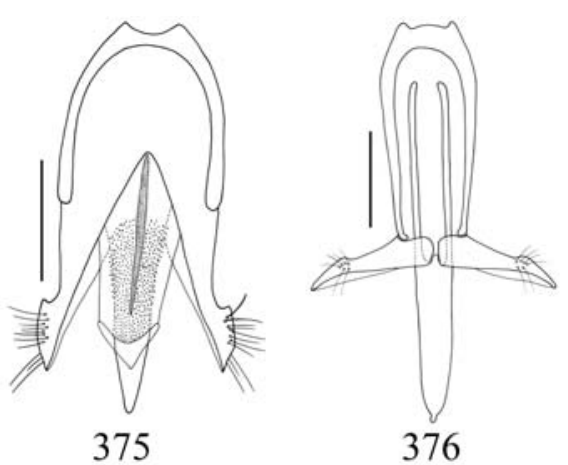

376

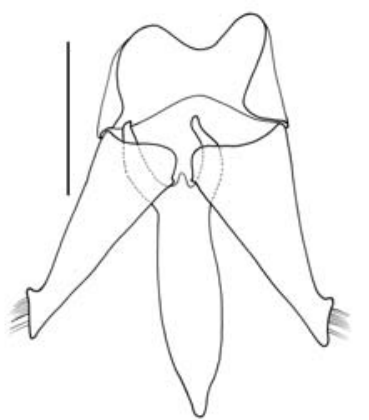

382

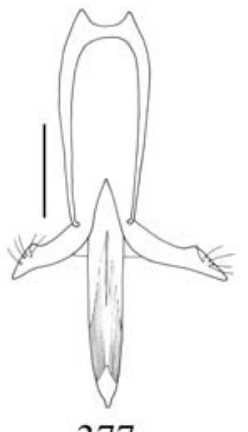

377

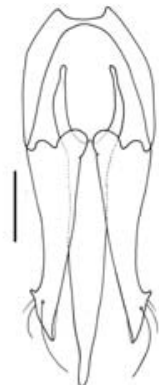

378

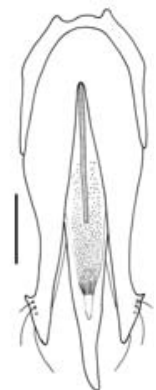

379

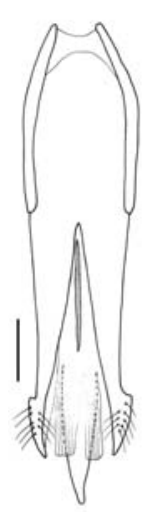

385

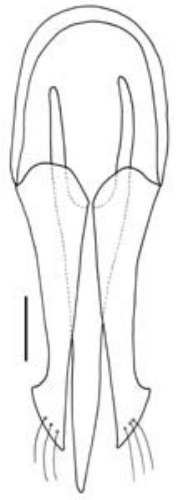

386

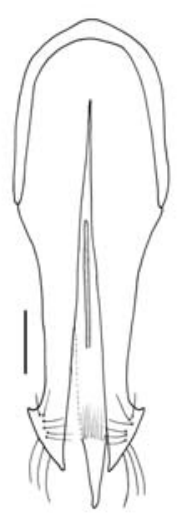

387
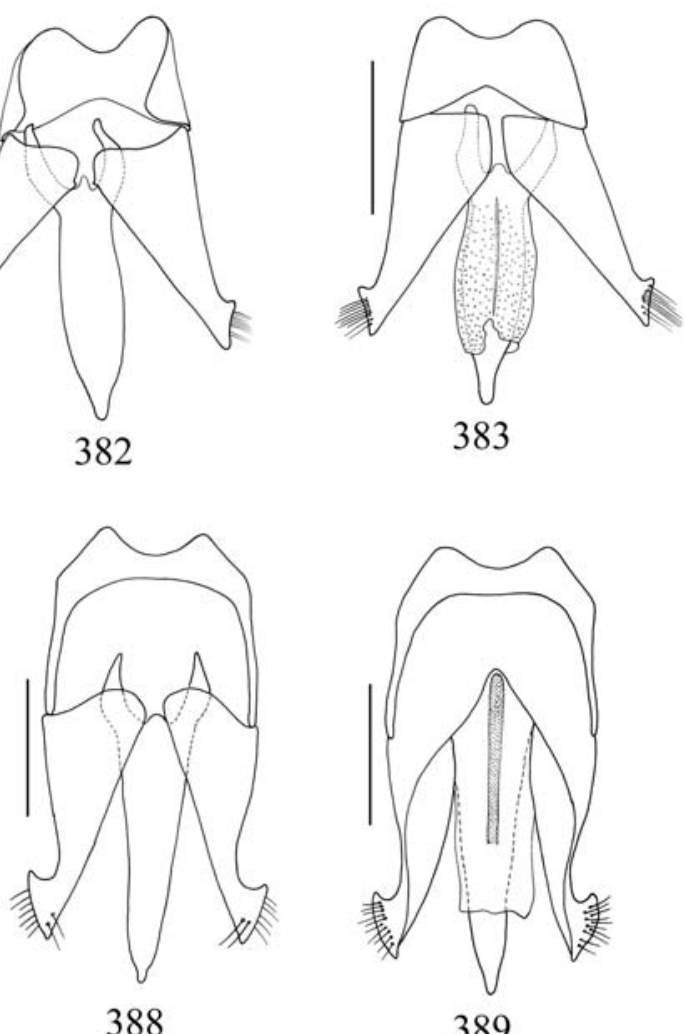

383

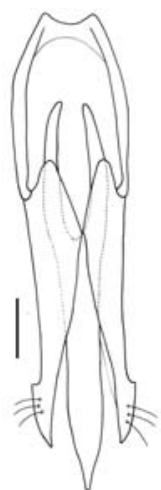

384

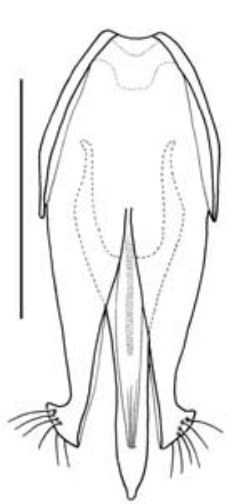

391

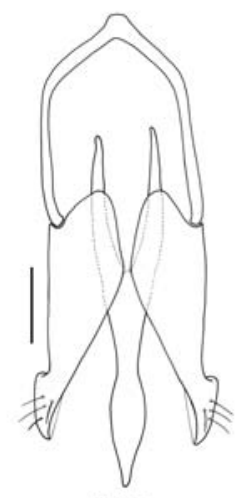

392

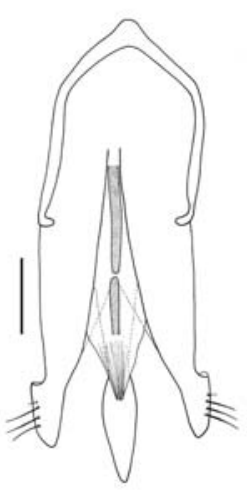

393
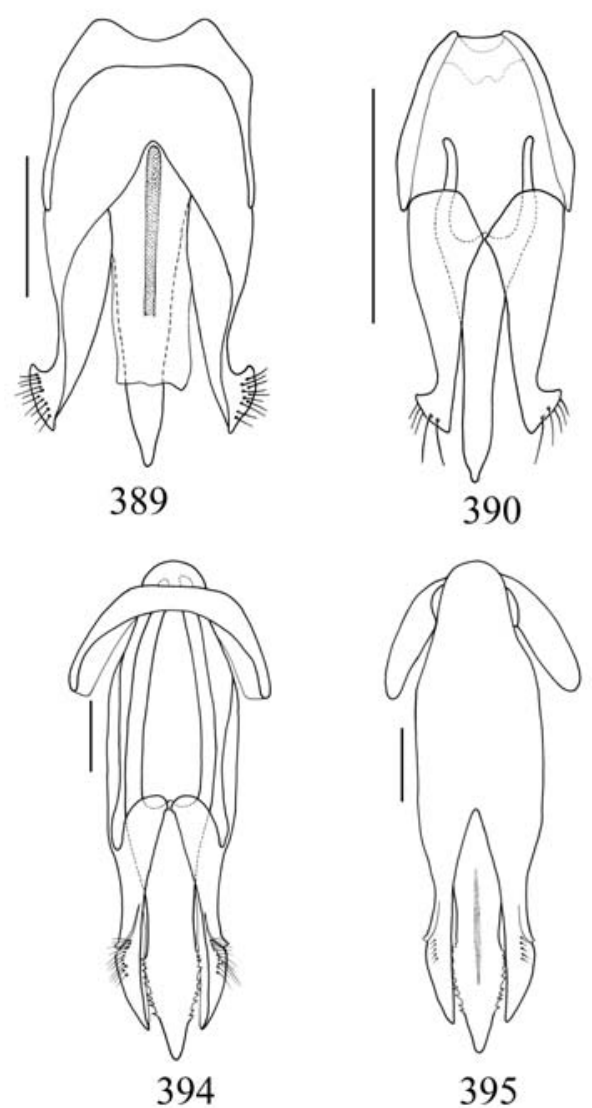

Figs. 374-395. Aedeagus (dorsal, ventral): 374, 375, Achrestus flavocinctus; 376, 377, Achrestus venustus; 378, 379, Adiaphorus gracilis; 380, 381, Adiaphorus ponticerianus; 382, 383, Ampedus sanguineus; 384, 385, Anoplischius bicarinatus; 386, 387, Anoplischius haematopus; 388, 389, Atractosomus flavescens; 390, 391, Blauta cribraria; 392, 393, Calopsephus apicalis; 394, 395, Chalcolepidius zonatus. Bars = 2 mm, except figs. $374-377,382,383=5 \mathrm{~mm}$, figs. $388,389=0.5 \mathrm{~mm}$, figs. $390,391,394,395=1 \mathrm{~mm}$. 
Male. Tergite 8 wider than long, narrowed apicad; anterior margin rounded; punctuate with setae near lateral and anterior margins; clothed with microtrichiae. Sternite 8 (Fig. 294) transverse, with anterior margin straight; anterior angles rounded; translucent with a narrow transversal basal sclerite; a band of setae near anterior margin. Sternite 9: apex gradually narrowed; distal half punctuate and setous. Tergite 9 (Fig. 355) strongly notched at middle; punctuate near lateral margins, with some long setae near angles; tergite 10 longer than 9, gradually narrowed to apex; punctuate and with some setae near middle of anterior half. Aedeagus (Figs. 424, 425) elongate; basal piece longer than parameres; parameres fused ventrally; median lobe wide, almost straight, slightly narrowed near middle with apex rounded; strongly longer than parameres; parameres with apex securiform.

Material examined. BRAZIL. Santa Catarina: 1 ex. (MNHN); Blumenau, 1 ex. (MNHN).

Lamononia Van Zwaluwenburg, 1928

Lamononia Van Zwaluwenburg, 1928: 118

Type-species: Lamononia monticola Van Zwaluwenburg, 1928, designated by monotypy.

Van Zwaluwenburg (1928) erected Lamononia, to $L$. monticola based on 2 specimens from Samoa (Malololelei, Upolu). According to him, "the strongly bent mucro distinguishes the new genus from Spilus, Ischiodontus and Pantolamprus, while the perpendicular mesosternal cavity makes confusion with Propsephus impossible."

The genus Lamononia, monotypical, is recorded only from type-locality.

No species of this genus was examined but by the original description it is possible to verify that it presents tarsomeres 2 and 3 lamellate, indicating that it belongs to Dicrepidiina.

\section{Lampropsephus Fleutiaux, 1928}

Lampropsephus Fleutiaux, 1928: 104.

Type-species: Psephus cyaneus Candèze, 1878, designated by monotypy.

Fleutiaux (1928) erected Lampropsephus to include one species of Psephus, P. cyaneus Candèze, 1878, from Tonkin. According to him, it is similar to some blue Pantolamprus, but the metasternum is not prominent between the mesocoxae and the borders of mesosternal cavity are horizontal.

The genus Lampropsephus, monotypical, is recorded only from the type-locality.

Lampropsephus cyaneus is characterized by one synapomorphy, 35(4) borders of mesosternal cavity slightly declivous followed by strongly declivous, and by homoplasies, 8(4) antennae of male serrate in both sides, 9(3) antennae of female serrate in both sides, 15(3) antennae of male not reaching hind angles apices, 18(1) labrum semicircular, 24(3) galea bilobed, 25(4) setae of galea simple and spatulate, 40(0) tibial spurs short, 60(1) apex of sternite 9 of male abruptly narrowed and 61(0) aedeagus short and wide. It belongs to a tricotomy formed by two other groups of genera.

Lampropsephus cyaneus (Candèze, 1878)

(Figs. 27, 78, 133, 134, 166, 198, 227, 292, 316, 327, 356, 426, $427,481,507)$.

Psephus cyaneus Candèze, 1878: 11; Fleutiaux, 1918: 204. Propsephus cyaneus; Schenkling, 1925: 97 (cat.).

Length: 14.0-16.5 mm. General integument black with shine metallic blue or violet; antennae black. Pubescence black, fine, moderately long and bristle. Frons carinate, wider than long; convex; anterior margin prominent, surpassing nasal; punctuation fine and dense. Nasal strongly wider than long. Antennae (Fig. 27) with 11 antennomeres; in male not reaching hind angles of pronotum; serrate, serrate in both sides in female; scape shorter than eye $2^{\text {nd }}$ antennomere globular, $3^{\text {rd }}$ triangular, shorter than $4^{\text {th }}$, last elliptical. Labrum (Fig. 78) semicircular and setous. Mandibles (Figs. 133, 134) wide with one apical and one subapical tooth; penicillus formed by short setae disposed in whole mesal area; molar area absent; dorsal region with carina and moderadely long setae. Maxillae (Fig. 166): galea bilobed with simple and spatulate setae; last palpomere securiform. Labium: prementum with setae in front of palpi; postmentum with 2 long setae and some shorter. Pronotum (Fig. 227) wider than long, narrowed to apex; strongly and roundly convex; lateral margins carinate; anterior margin slightly notched; hind angles slightly divergent and carinate; median basal tubercle flat; punctuation fine and moderately dense, sparser near base. Prosternal channel long. Prosternal spine (Fig. 198) with subapical lobe. Borders of mesosternal cavity wide, slightly declivous (almost horizontal) and distally more strongly declivous. Metacoxal plate slightly narrowed laterally; free margin with small lobe. Tibial spurs short; tarsomeres 2-3 lamellate beneath. Scutellum elongate with posterior margin rounded and lateral margins notched. Elytra strongly convex, narrowed on distal half; striae weakly punctuated; interstices equal and flat.

Male. Tergite 8 (Fig. 316) wider than long, slightly narrowed apicad; anterior margin rounded; with long setae near margins; clothed with microtrichiae. Sternite 8 (Fig. 292) transverse; anterior margin slightly notched at middle; anterior angles rounded; moderately long setae near lateral margins. Sternite 9 (Fig. 327): distal third abruptly narrowed apicad; distal half setous, specially near middle. Tergite 9 (Fig. 356) strongly notched at middle, V-shaped; partially punctuate with many setae near angles; tergite 10 shorter than 9 , setous on distal half. Aedeagus (Figs. 426, 427) short and wide; basal piece shorter than parameres; parameres fused ventrally; median lobe gradually narrowed to apex; slightly longer than parameres; parameres with apex cuneiform, notched at subapical region.

Female. Tergite 8 transverse, slightly narrowed to apex; anterior margin rounded; partially clothed with short setae, the marginal 


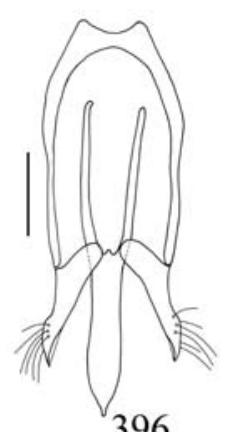

396

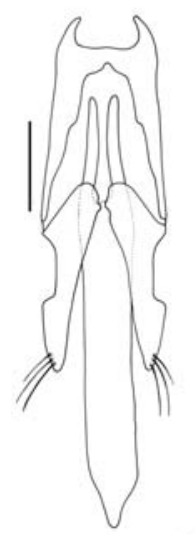

402

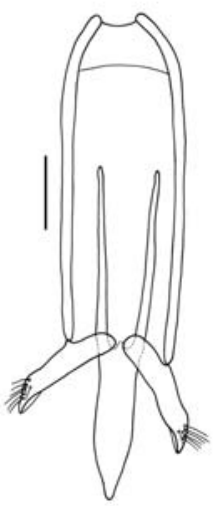

408

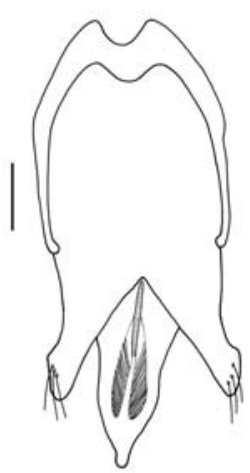

413
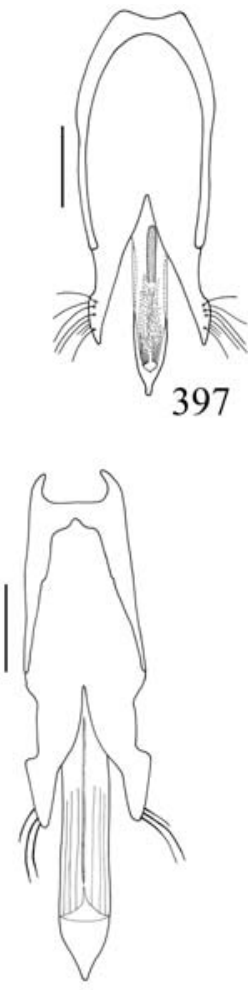

403

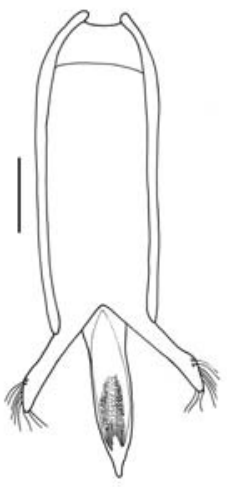

409

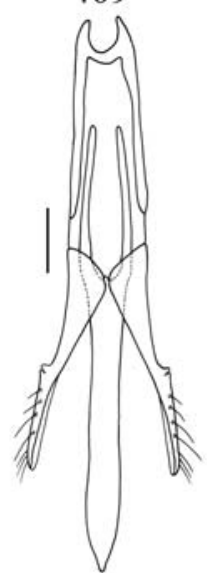

414
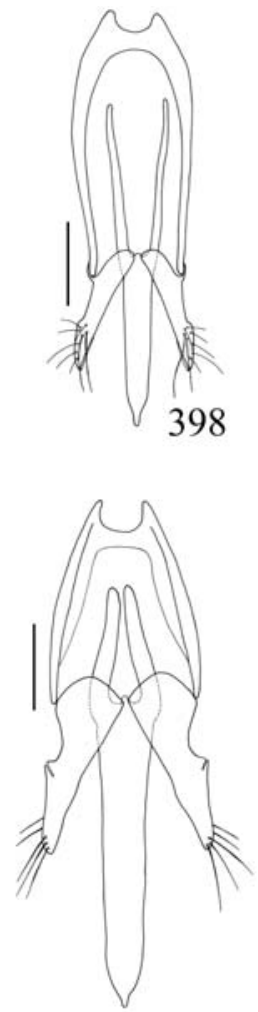

404

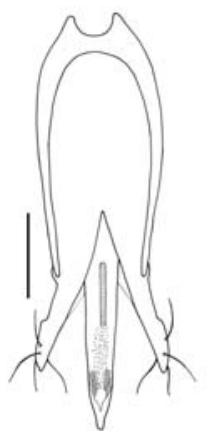

399

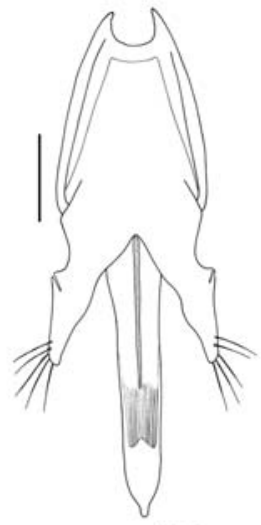

405

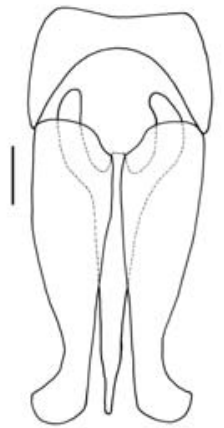

400

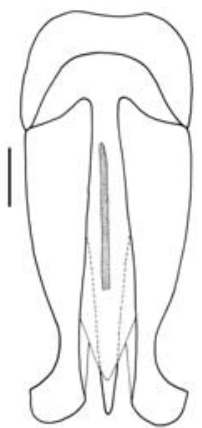

401

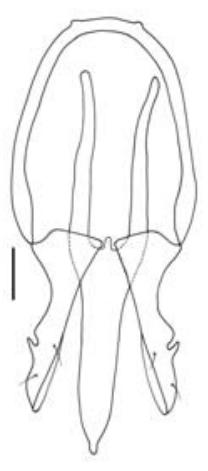

406

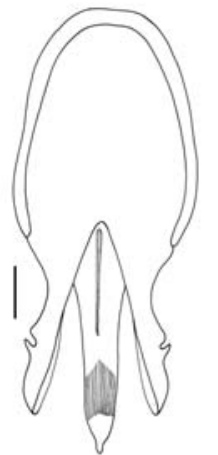

407

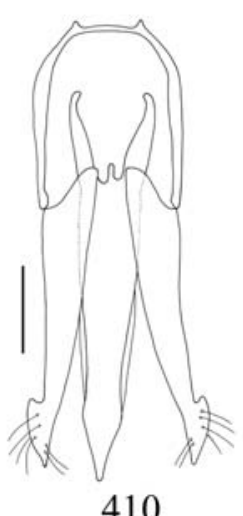

410

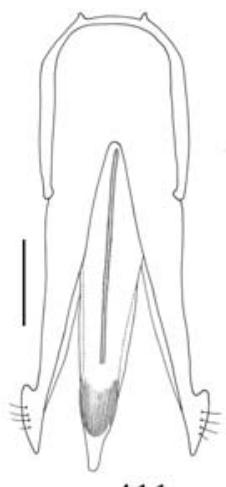

411

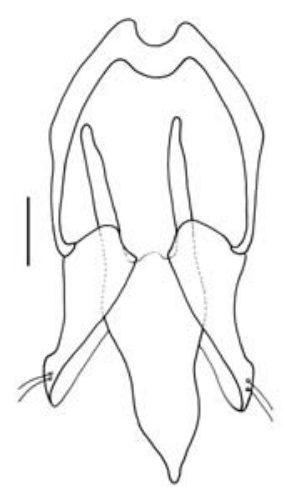

412
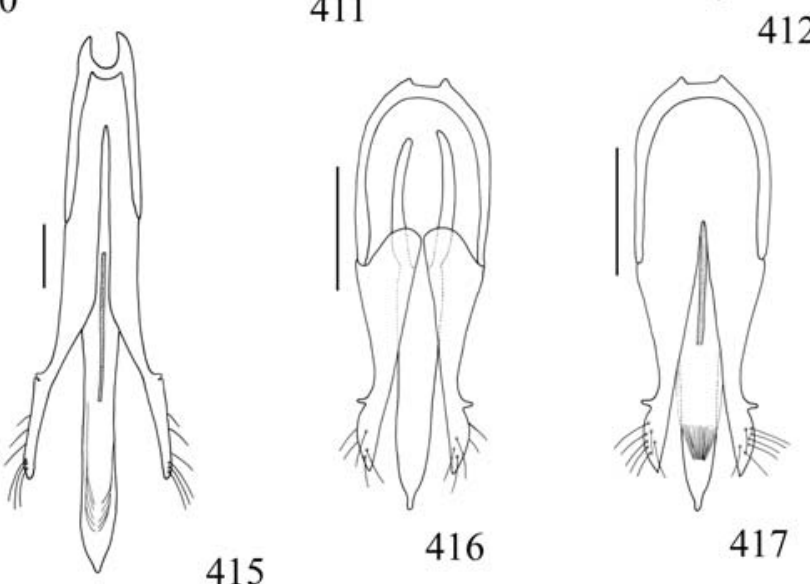

Figs. 396-417. Aedeagus (dorsal, ventral): 396, 397, Crepidius flabellifer; 398, 399, Crepidius resectus; 400, 401, Ctenicera silvatica; 402, 403, Cyathodera lanugicollis; 404, 405, Cyathodera longicornis; 406, 407, Dayakus angularis; 408, 409, Dicrepidius ramicornis; 410, 411, Dipropus brasilianus; 412, 413, Dipropus factuellus; 414, 415, Dipropus laticollis; 416, 417, Dipropus schwarzi. Bars = 2 mm, except figs. 396$399=1 \mathrm{~mm}$, figs. $402-405=10 \mathrm{~mm}$, figs. $408-411,414-417=5 \mathrm{~mm}$. 
longer. Sternite 8 (Fig. 481) elongate, narrowed on distal half; partially clothed with short setae; spiculum gastrale 3.17 times sternite length. Ovipositor with stylus; bursa copulatrix (Fig. 507) with 7 spiny areas, some of them star-like.

Material examined. TONKIN. [Vietnam] Hoa Binh, 2 exs. (MNHN).

Loboederus Guérin-Méneville, 1831

Loboederus Guérin-Méneville, 1831: 9, t. 9; Latreille, 1834: 148; Castelnau, 1840: 239; Blackwelder, 1944: 298 (cat.); Camargo-Andrade, 1935: 438, 439; Casari, 2004:459.

Lobederus; Lacordaire, 1857: 167, 169; Candèze, 1859: 9, 78; Schenkling, 1925: 82.

Loboderus Schwarz, 1906: 61, 69.

Type species: Elater appendiculatus Perty, 1830, designated by monotypy.

Perty (1830) described Elater appendiculatus, from São Paulo, Brazil, characterized, besides the hind angles of pronotum with internal appendices, by antennae serrate with last antennomere "lanceolate".

Guérin-Méneville (1831) erected Loboederus to $L$. monilicornis from São Paulo, Brazil. Latreille (1834) redescribed Loboederus, only with L. monilicornis Guérin, considering the last antennomere with "false article" and, erroneously, recorded it from "Java".

Castelnau (1840) redescribed the genus and considered Elater appendiculatus Perty, 1830 as synonym of Loboederus monilicornis Guérin, 1831.

Lacordaire (1857) described the antennae as filiform in females and serrate in males, with last antennomere longer with rounded apex. According to him, Guérin-Méneville ( $l$. $c$.) examined only females because he did not describe the lamellae of tarsi, invisible in females, and also, had not mentioned the sexual differences of antennal shape and lenght. He considered the genus formed only by $L$. appendiculatus Perty, from São Paulo, Brazil, but stated that "M. GuérinMéneville, qui l'a décrit presque em même temps que M. Perty, l'a nommé $L$. monilicornis...". He commented the error of Latreille (1834) recording it from Java.

Candèze (1859) redescribed the genus with only one species. According to him, Guérin- Méneville (1831) and Latreille (1834) described this species at same time and Latreille, erroneously, recorded it from Java. He stated also that Latreille (1834) considered the tarsi with only one lamella under 3rd article, but he (Candèze) noted another, small, under $2^{\text {nd }}$, but they are well visible only on anterior tarsi of male and are almost absent on females.

Candèze (1891) catalogued this genus only with $L$. appendiculatus (L. monilicornis as synonym).

Schwarz (1906) presented a key to genera and redescribed the "Genus Loboderus [sic]Guérin", formed by $L$. appendiculatus.

Hyslop (1921) designated Loboederus monilicornis as the type species and added a note: "Candèze (1859) reduces the type to synonymy under Lobederus appendiculatus Perty".

Schenkling (1925) catalogued one species to this genus.
Camargo-Andrade (1935) presented an historical review of the genus discussing the previous authors and described a new species, $L$. luederwaldti. He also redescribed the genus and $L$. appendiculatus.

Lesne (1940) described Loboederus fleutiauxi.

Blackwelder (1944) catalogued two species to Lobaederus [sic].

Casari (2004) presented a revision of the genus and synonymized $L$. fleutiauxi Lesne, 1940 under $L$. luederwaldti Camargo-Andrade, 1935.

The genus Loboederus is formed by two species: $L$. appendiculatus Perty, 1830 (= L. monilicornis Guérin, 1831) and L. luederwaldti, 1935 (=L. fleutiauxi Lesne). It is recorded from Brazil.

Loboederus appendiculatus is characterized by one synapomorphy, 30(0)hind angles of pronotum with posterolateral appendix, and by homoplasies, 7(2) nasal as wide as long, 14(2) antennomere 3 as long as 4,21(1) mesal area of mandibles with one apical and one subapical tooth near apex, 22(1) penicillus reduced, 27(0) last palpomere securiform, 31(1) carina of hind angles of pronotum absent, 33(1) prosternal channel present, 37(1) free margin of metacoxal plate with small lobe, 63(0) parameres separated and 67(6) lateral margins of median lobe slightly narrowed at middle. It is the sister-group of Proloboderus crassipes.

Loboederus appendiculatus (Perty, 1830) (Figs. 28, 79, 230, 295, 328, 357, 428, 429, 482).

Elater appendiculatus Perty, 1830: 21.

Loboederus appendiculatus; Gemminger \& Harold, 1869: 1514 (cat.); Candèze, 1859: 79; Casari, 2004: 460.

Length: 15-20 mm. Frons carinate, wider than long; concave medioanteriorly; anterior margin strongly prominent at middle, surpassing nasal; punctuation coarse and dense. Nasal high, as long as wide. Antennae (Fig. 28) with 11 antennomeres; in male 3.2 antennomeres longer than hind angles of pronotum; slightly serrate; scape shorter than eye; $2^{\text {nd }}$ antennomere globular, $3^{\text {rd }}$ triangular, as long as $4^{\text {th }}$, last elliptical; antennomeres 5-11 with or without longitudinal smooth band. Labrum (Fig. 79) semielliptical and setous. Mandibles narrow with one subapical tooth; penicillus short, formed by short setae disposed in small mesal area; dorsal region with carina and moderately long setae. Maxillae: galea with simple setae; last palpomere securiform. Pronotum (Fig. 230) strongly convex, slightly grooved longitudinal medially and parallel lateral margins; wider than long, strongly narrowed to apex; lateral margins incompletely carinate; anterior margin prominent at middle; hind angles not carinate, backwardly directed with posterolateral appendix; median basal tubercle flat and rounded; punctuation coarse and dense. Prosternal channel long. Prosternal spine with apex narrowed. Borders of mesosternal cavity slightly declivous. Metacoxal plate strongly narrowed laterally; free margin with small lobe. Tibial spurs long; tarsomeres 2-3 lamellate beneath.

Male. Sternite 8 (Fig. 295) transverse, slightly narrowed 

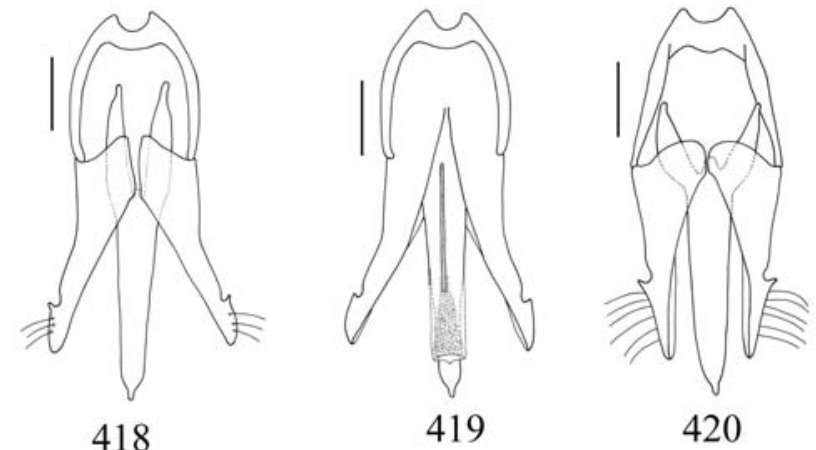

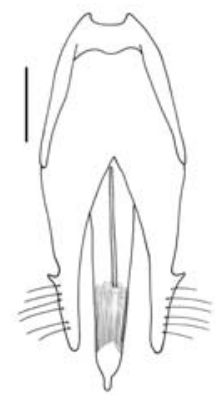

421

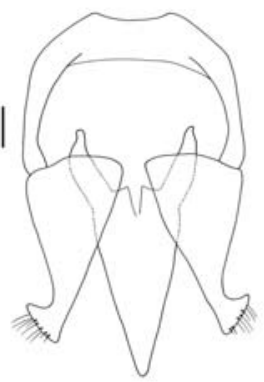

426

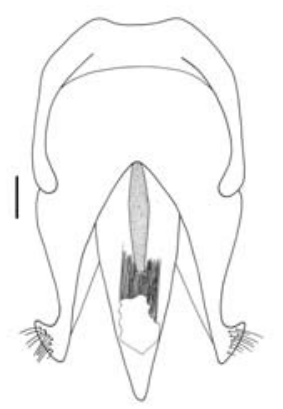

427

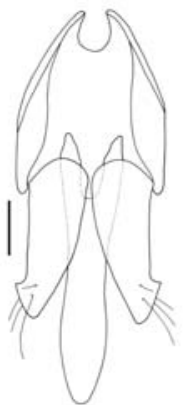

422

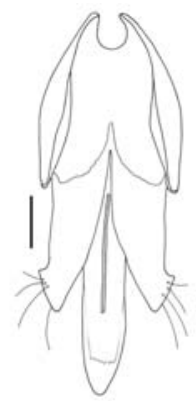

423

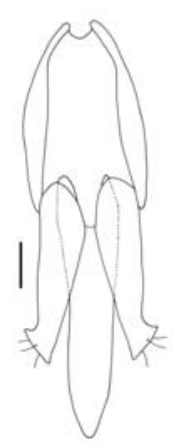

424

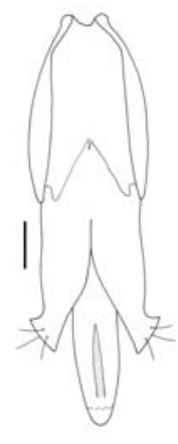

425

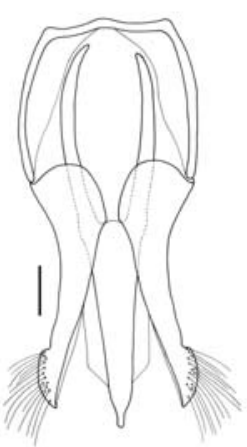

430

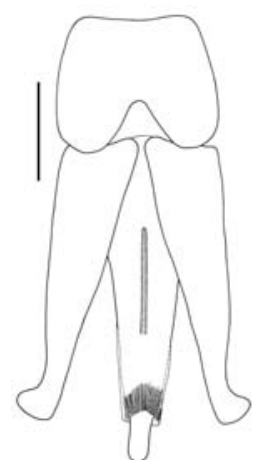

435

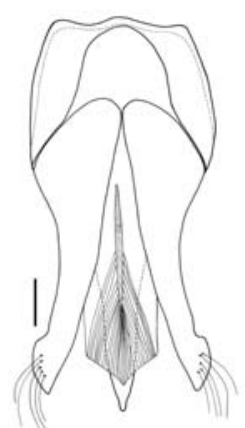

431

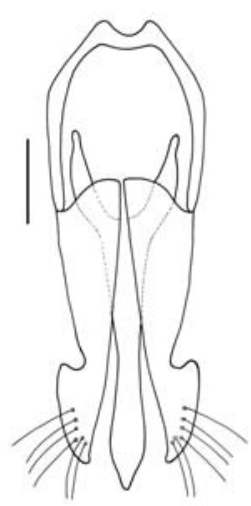

436

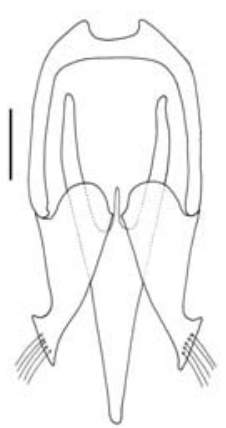

432

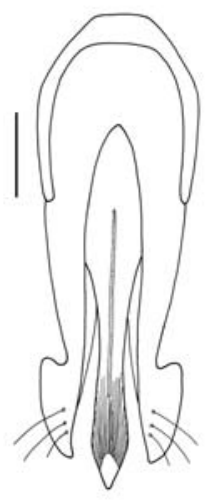

437
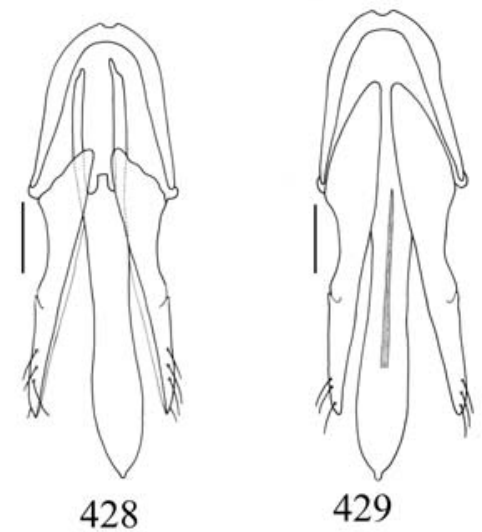

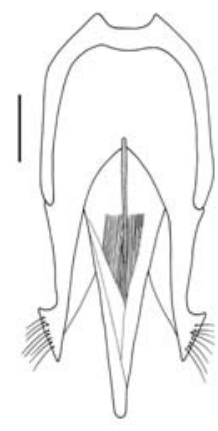

433

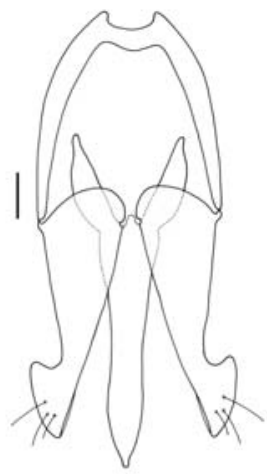

438

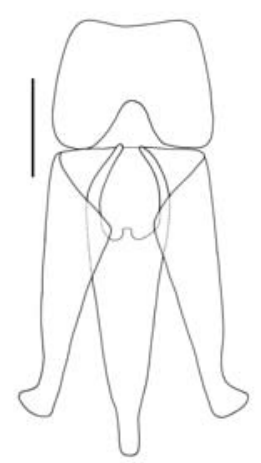

434

Figs. 418-439. Aedeagus (dorsal, ventral): 418, 419, Elius birmanicus; 420, 421, Elius dilatatus; 422, 423, Heterocrepidius gilvellus; 424, 425, Heterocrepidius ventralis; 426, 427, Lampropsephus cyaneus; 428, 429, Loboederus appendiculatus; 430, 431, Melanotus spernendus; 432, 433, Olophoeus gibbus; 434, 435, Ovipalpus pubescens; 436, 437, Pantolamprus ligneus; 438, 439, Pantolamprus perpulcher. Bars = 2 mm, except figs. 418$421,428,429=0.5 \mathrm{~mm}$, figs. $432-437=5 \mathrm{~mm}$. 
apicad; anterior margin strongly notched at middle; anterior angles prominent and rounded; translucent in a lateral band and at middle; setae moderately long near lateral margins and at middle. Sternite 9 (Fig. 328): distal half abruptly narrowed to apex; distal third setous. Tergite 9 (Fig. 357) slightly notched at middle; punctuate; tergite 10 narrow, longer than 9, punctuate laterally and with a few setae. Aedeagus (Figs. 428, 429) elongate; basal piece shorter than parameres; parameres separate ventrally; median lobe narrowed near middle and constricted at apex; much longer than parameres; parameres cleft subapically.

Female. Sternite 8 (Fig. 482) wider than long, narrowed on distal half; partially clothed with short setae; spiculum gastrale 3.43 times sternite length. Ovipositor with stylus; bursa copulatrix without spines or sclerotized pieces.

Material examined. BRAZIL. 1 ex. (MNHN). Goiás: Anápolis (Chácara Tangará), 1 ex. (MZSP); Leopoldo Bulhões, 1 ex. (IBSP); Rio Verde, 1 ex. (MZSP). Distrito Federal: Brasília (Cidade Universitária), 1 ex. (MZSP). Bahia: Encruzilhada, 960 m, 2 exs. (DZUP). Mato Grosso: Chavantina, 1 M (dissected) (MZSP); Dourados, 1 ex. (DZUP); Rio Brilhante, 1 ex. (DZUP); Salobra (Instituto Oswaldo Cruz, Zona da N. O. B.), 1 ex. (MZSP); Utiariti (Rio Papagaio), 1 ex. (MZSP). Mato Grosso do Sul: Fátima do Sul (Sítio Alpha), 1 ex. (MZSP). Minas Gerais: Arinos, 1 ex. (MZSP); Uberaba, 3 exs (MNHN);Uberlândia, 1 ex. (MZSP). São Paulo: Andes, 3 exs (MZSP); Batatais, 1 ex. (MZSP); Botucatu, 5 exs. (1 F dissected) (MZSP); Itápolis, 1 ex. (MZSP); Itu, 1 ex. (MZSP); Nova Europa (Faz. Itaquerê), 2 exs. (MZSP); Piraju, 2 exs. (MZSP); Pirassununga, 2 exs. (MZSP); Regente Feijó, 1 ex. (MZSP); Ribeirão Preto (Tamanduá), 2 exs (MZSP); (Coqueiros), 1 ex. (MZSP); (Fac. Medicina), 1 ex. (MZSP); Rio Claro (Campus), 1 ex. (MZSP); São José dos Campos, 1 ex. (MZSP); São Paulo (Cantareira), 1 ex. (MZSP). Paraná: Campo Mourão, 1 ex. (DZUP).

\section{Neopsephus Kishii, 1990}

Neopsephus Kishii, 1990:12.

Type-species: Neopsephus takasago Kishii, 1990, designated by monotypy.

Kishii (1990) erected Neopsephus to a new species, $N$. takasago, based on a female from Taiwan. He compared this genus with Lampropsephus Fleutiaux, 1928 and Sphenomerus Candèze, 1859.

The genus Neopsephus, monotypical, is recorded only from type-locality.

No specimen of this genus was examined but, by the original description is possible to verify that it presents tarsomeres 2 and 3 lamellate indicating that it shoul be kept in Dicrepidiina.

\section{Olophoeus Candèze, 1859}

Olophoeus Candèze, 1859: 9, 15; 1891: 50 (cat.); Schwarz, 1899: 65; 1906: 59, 76; Fleutiaux, 1919: 38, 40; 1935a: 201; Schenkling, 1925: 87 (cat.); Burgeon, 1947: 17; Quelle, 1955: 228; Basilewsky, 1958: 382 .

Type-species: Olophoeus gibbus Candèze, 1859, designated by monotypy.

Candèze (1859) erected Olophoeus to a new species, $O$. gibbus, from Gabon. In 1891 he catalogued the genus with only one species.
Schwarz (1906) included 9 species in the genus.

Schenkling (1925) catalogued 14 species to this genus.

Fleutiaux (1935a) discussed about the type-species of Psephus and Olophoeus. He also described Olophoeus elgonensis and $O$. gerstaeckeri.

Burgeon (1947) treated of 20 species, from which 10 species and 1 subspecies were new. He also grouped the 19 species from Congo into 4 groups; the remainder was included in any group.

Basilewsky (1958) redescribed the genus and described two species and two subspecies, one to O. cinnamomeus Schwarz and one to $O$. guineensis Candèze. He also presented an identification key and the geographical distribution for 18 species.

Girard (1974) described 4 species.

The genus Olophoeus is formed by 35 species: $O$. aemidioides Burgeon,1947, O. alternans Burgeon, 1947,O. antennalis (Fleutiaux, 1918), O. bequaerti Burgeon, 1947, O. brachycerus Burgeon, 1947, O. brunnipennis Schawrz, 1908, O. brunneus Girard, 1974, O. christophei Girard, 1974, O. cinnamomeus Schwarz, 1901 (Ssp. burgeoni Basilewsky, 1958), O. elgonensis Fleutiaux, 1935, C. gaedikei Girard, 1974, O. gerstaeckeri Fleutiaux, 1935, O. gibbus Candèze, 1859, O. granulipennis (Candèze, 1891) (=Psephus granulatus Candèze, 1878), O. guineensis (Candèze, 1881) (Ssp. antennatus Candèze, 1896, Ssp. katanganus Basilewsky, 1958, Ssp. guineensis Burgeon, 1947), O. kigonseranus Burgeon, 1947, O. maculatus (Schwarz, 1908), O. massarti Burgeon, 1947, O. mechowi (Candèze, 1881), O. melancholicus (Candèze, 1881), O. minutus Schwarz, 1906, O. mutatus (Fleutiaux, 1919), O. nubilus (Klug, 1855) (=Psephus radula Candèze, 1896), O. parallelus (Candèze, 1859), O. protensus (Gerst., 1884) (=Psephus rugulipennis Fairm., 1891), O. quadricollis Burgeon, 1947, O. quellei Basilewsky, 1958, O. rugosus Schwarz, 1899, O. russatus (Fairmaire, 1887), O. semiferrugineus Schwarz, 1896, O. seydeli Basilewsky, 1958, O. soricinus Burgeon, 1947, O. transvaalensis Girard, 1974, O. vanderstichelei Burgeon, 1947, O. vrydaghi Burgeon,1947. It is widely recorded from Africa (Guinea, Nigeria, Cameroon, Gabon, Congo, Democratic Republic of Congo, Somalia, Angola, Tanzania, Mozambique, South Africa,).

Olophoeus gibbus is characterized by one synapomorphy, 20(2) mandibles quadrangular, and by homoplasies, 0 (2) frons as wide as long, 3(0) anterior margin of frons at nasal level, $8(5)$ antennae of male strongly serrate, 14(0) antennomere 3 longer than 4, 18(3) labrum subrectangular, 58(2) distal margin of tergite 9 of male moderately notched at middle, 61(0) aedeagus short and wide and 66(2) median lobe strongly longer than parameres. It belongs to a polytomy formed by Anoplischiopsis bivittatus, Pseudolophoeus guineensis and Adiaphorus.

Olophoeus gibbus Candèze, 1859

(Figs. 30, 81, 137, 138, 168, 231, 297, 359, 432, 433).

Olophoeus gibbus Candèze, 1859: 15; Murray, 1878: 145; Schwarz, 1899: 65, 67; Schenkling, 1925: 87 (cat.). 

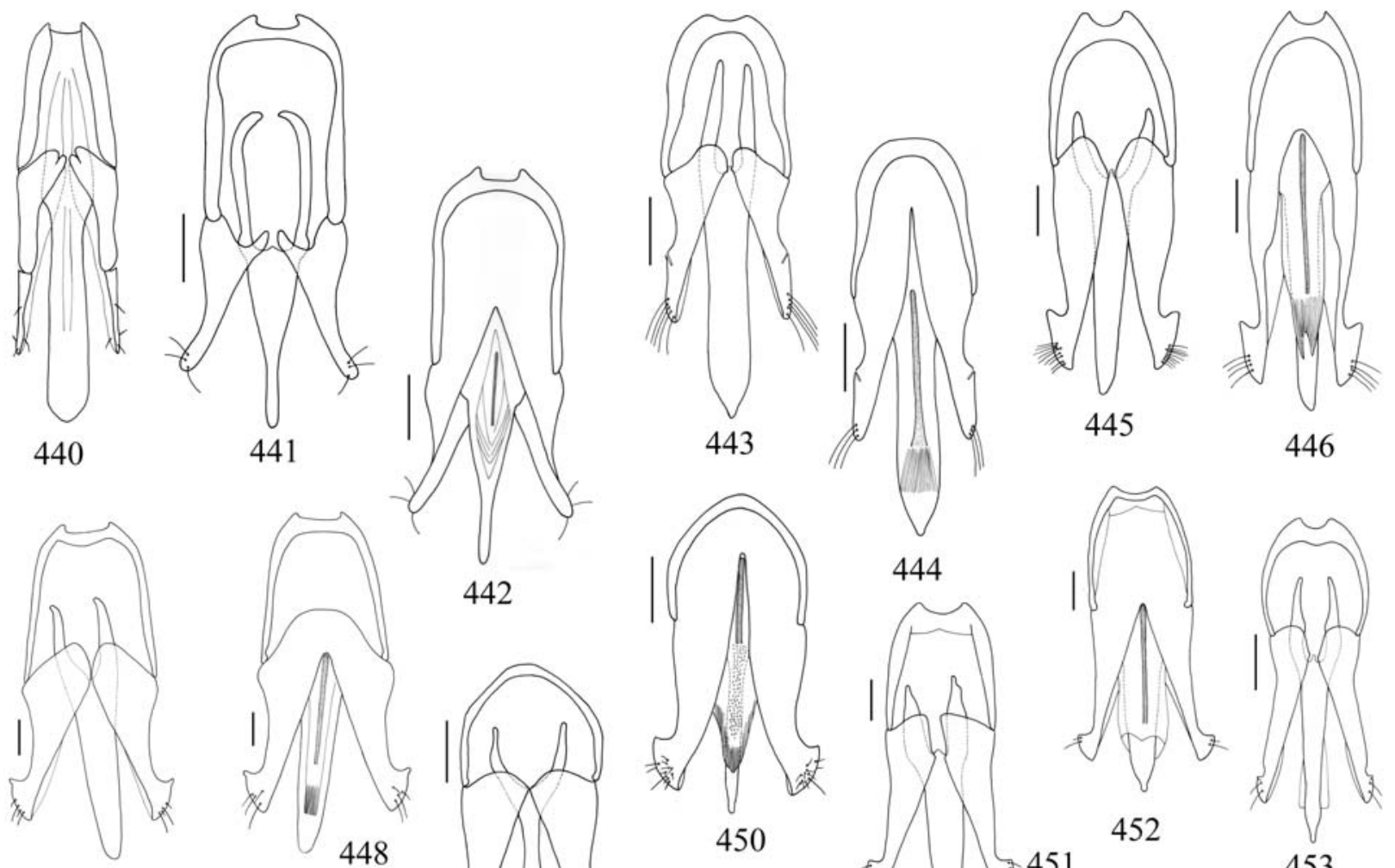

447
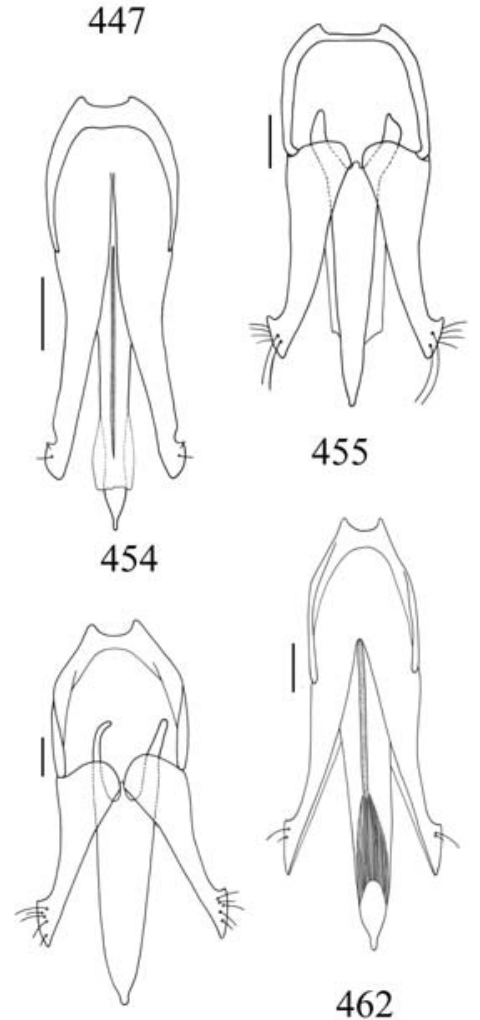

461

462
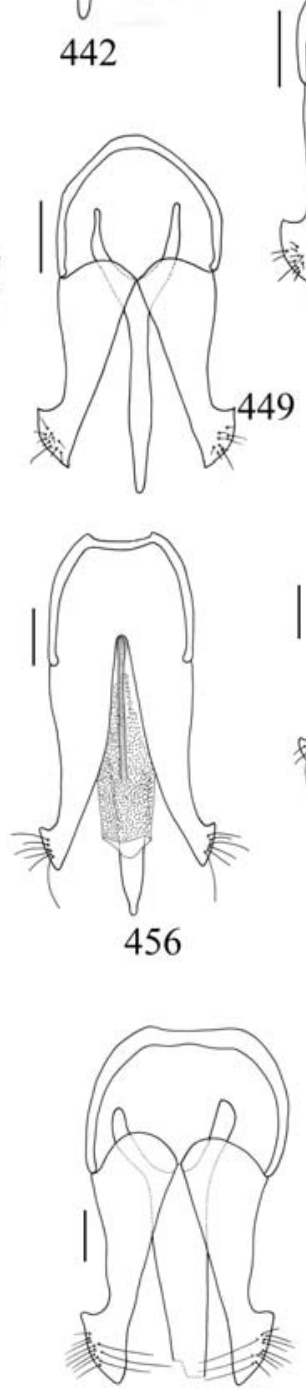

463
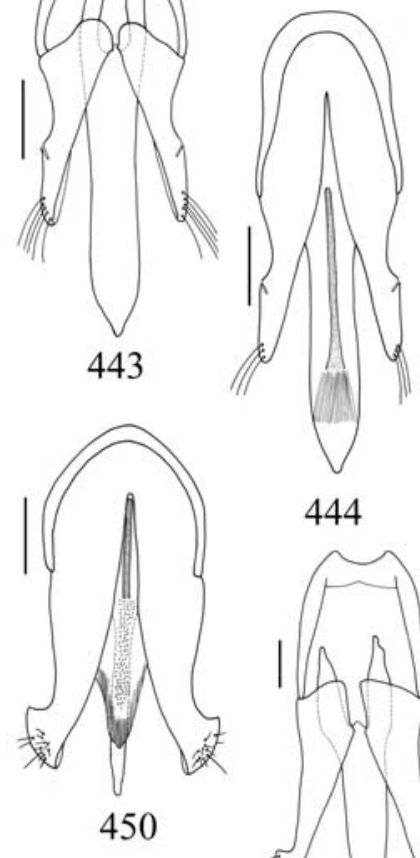

445

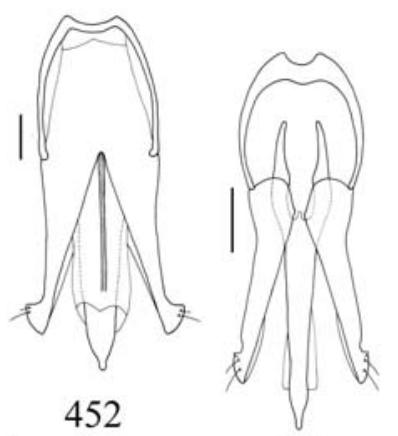

451

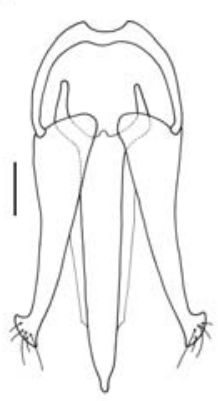

457
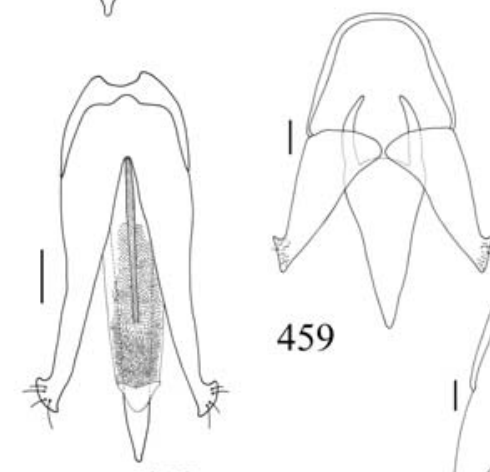

459

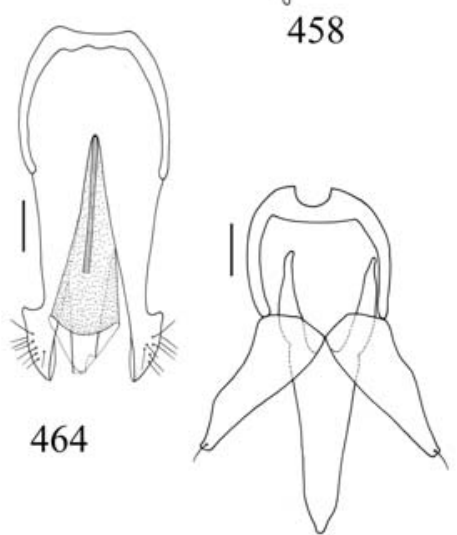

465
453

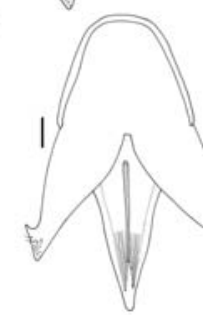

460

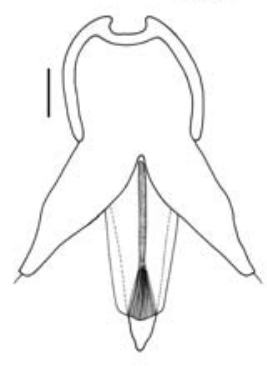

466

Figs. 440-466. Aedeagus (dorsal, ventral): 440, Paraloboderus glaber (adapted from Golbach, 1990); 441, 442, Physorhinus xanthocephalus; 443, 444, Proloboderus crassipes; 445, 446, Propsephus beniensis; 447, 448, Pseudolophoeus guineensis; 449, 450, Rhinopsephus apicalis; 451, 452, Sephilus formosanus; 453, 454, Sephilus frontalis; 455, 456, Singhalenus gibbus; 457, 458, Singhalenus taprobanicus; 459, 460, Sphenomerus antennalis; 461, 462, Sphenomerus brunneus; 463, 464, Spilus nitidus; 465, 466, Stenocrepidius simoni. Bars = 2 mm, except figs. $443,444,453,454=0.5 \mathrm{~mm}$, figs. $445-446=5 \mathrm{~mm}$. 
Length: $28.5 \mathrm{~mm}$. General integument reddish-brown with antennae and legs clearer. Pubescence golden, moderately long and dense. Frons carinate, as long as wide; convex, prominent medioanteriorly, not surpassing nasal; punctuation moderately coarse and very dense. Nasal short, very wider than long. Antennae (Fig. 30) with 11 antennomeres; in male one antennomere longer than hind angles of pronotum; strongly serrate; scape shorter than eye; $2^{\text {nd }}$ antennomere globular, $3^{\text {rd }}$ triangular elongate, longer than $4^{\text {th }}$, last narrowed at apex. Labrum (Fig. 81) subrectangular with rounded angles and setous. Mandibles (Figs. 137, 138) quadrangular, lateral margin straight, with one apical and one subapical tooth; penicillus reduced to basal area, formed by short setae disposed in small mesal area; molar area absent; dorsal region with carina and moderadely long setae. Maxillae (Fig. 168): galea with simple setae; medio- and basistipes partially fused; last palpomere elliptical. Labium: prementum with setae in front of palpi; postmentum with 2 long setae and several moderately long. Pronotum (Fig. 231) wider than long, wider near middle; strongly convex; lateral margins carinate; anterior margin straight; hind angles backwardly directed and carinate; median basal tubercle transverse and flat; punctuation moderately coarse and very dense. Prosternal channel short. Prosternal spine with small lobe near apex. Borders of mesosternal cavity slightly declivous. Metacoxal plate slightly narrowed laterally; free margin straight. Tibial spurs long; tarsomeres 2-3 lamellate beneath. Scutellum subtriangular elongate with lateral margins notched. Elytra convex, slightly narrowed on distal third; striae grooved and punctuated; interstices equal and slightly convex; $4^{\text {th }}$ and $6^{\text {th }}$ interstices fused near apex.

Male. Tergite 8 wider than long, subtriangular with rounded apex; translucent in a small triangular basal area and a distal narrow band; marginate by fringe of setae; clothed with microtrichiae. Sternite 8 (Fig. 297) transverse, with anterior angles rounded; partially translucent; setae moderately long near anterior and lateral margins. Sternite 9: distal half gradually narrowed to apex; distal half setous. Tergite 9 (Fig. 359): anterior margin moderately notched at middle, V-shaped; punctuate laterally; tergite 10 longer than 9 , with setae near margins of distal half. Aedeagus (Figs. 432, 433) elongate, wide; basal piece longer than parameres; parameres fused ventrally; median lobe gradually narrowed apicad; moderately longer than parameres; parameres cuneiform notched subapically.

Material examined. GHANA. Tafo, 1 ex. (MZSP). CENTRAL AFRICAN REPUBLIC. La Maboké, 3 exs (MNHN). CAMEROON. Nkolbisson (Yaoundé), 1 ex. (MNHN); Balauga, 1 ex. (MNHN). GABON. Benito, 2 exs (MNHN); Talagouga, 1 ex. (MNHN).

\section{Pantolamprus Candèze, 1859}

Pantolamprus Candèze, 1859: 9, 16; 1891: 50 (cat.); Schwarz, 1906: 59, 62; Fleutiaux, 1919: 38, 39; Schenkling, 1925: 74 (cat.); Basilewsky, 1958: 339; Girard, 1971: 590; Girard, 2003b: 463.

Subgen. Xantholamprus Fleutiaux, 1935b: 304. Type-species of subgenus: Pantolamprus sulcicollis Schwarz, 1896, by original designation.
Type-species: Ampedus savagei Hope, 1843. Hyslop (1921) designated Pantolamprus nitens Candèze, 1859; Basilewsky (1958) synonymized it under P. savagei (Hope, 1843).

Candèze (1959) established Pantolamprus to one new species, P. nitens, and one species transferred from Ampedus Westwood, 1842, A. perpulcher Westwood, 1842, both from Africa. In 1891 he catalogued 5 species to this genus. In 1882 described a new species, P. auratus.

Schwarz (1906) included 14 species in the genus.

Fleutiaux (1919) treated of Pantolamprus mirabilis Candèze (1896), P. purpureus Schwarz (1899) and a new species, $P$. cyanipennis.

Hyslop (1921) considered Pantolamprus nitens as the typespecies of the genus.

Schenkling (1925) catalogued 15 species to this genus.

Fleutiaux (1935b) described P. terminatus and erected the subgenus Xantholamprus to include the species with elytra not metallic and strongly striate like, $P$. sulcicollis, Schwarz, 1896 and P. ligneus Candèze, 1896.

Fleutiaux (1935c) designated P. sulcicollis as the typespecies of the subgenus Xantholamprus and described $P$. monardi, $P$. niger, $P$. antennalis, $P$. canaliculatus and $P$. praestus.

Basilewsky (1958) redescribed the genus Pantolamprus, described one species, $P$. kivuensis and considered $P$. ruficollis Fleutiaux, 1902 as synonym of $P$. cyanocephalus (Hope, 1843), and $P$. nitens as synonym of $P$. savagei. He also presented an identification key and redescriptions to 11 species from Congo.

Cobos (1970) recorded Pantolamprus (s.str.) cyanocephalus and P. (s. str.) rufipes Harold (1878) to Congo.

Girard (1971) recorded P. cyanocephalus to Lamto (Côte d'Ivoire). According to him, this genus includes about 20 species, all from Africa intertropical.

Girard (2003a) commented that the presence of the borders of mesosternal cavity vertical as diagnose of Pantolamprus (Pantolamprus), occurs also in Catalamprus and Pantolamprus (Xantholamprus), but the former has coloration bright and metallic. He recorded $P$. auripennis, $P$. cyanocephalus and $P$. perpulcher from Nimba.

Girard (2003b) described P. neavei and designated the lectotypes to P. mirabilis Candèze, 1896 and $P$. nigripes Quedenfeldt, 1886. He described two varieties to $P$. cyanocephalus, one to $P$. perpulcher (Westwood, 1842), three to $P$. rufangulus Fleutiaux, 1902 and one to P. nigripes; P. rohanchaboti Fleutiaux, 1925 was considered a variety of the latter.

The genus Pantolamprus is formed by 27 species: $P$. angustus Fleutiaux, 1902, P. antennalis Fleutiaux, 1935, P. auripennis (Hope, 1843) (=Ampedus auripennis Hope, 1843, $=$ Pantolamprus perpulcher var. auripennis; Candèze, 1859, = Var. dohrni (Candèze, 1881), = Pantolamprus dohrni Candèze, 1881, = Var. rubeoviolaceus Girard, 1992), P. auratus Candèze, 1882, P. candezei Fleutiaux, 1902, P. (Xantholamprus) canaliculatus Fleutiaux, 1935b, P. cyanipennis Fleutiaux, 1919, P. dohrni Candèze, 1881, P. (Xantholamprus) kivuensis 


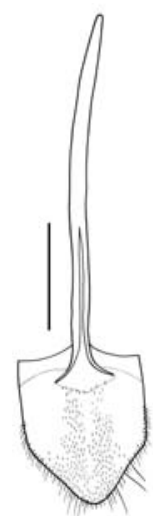

467
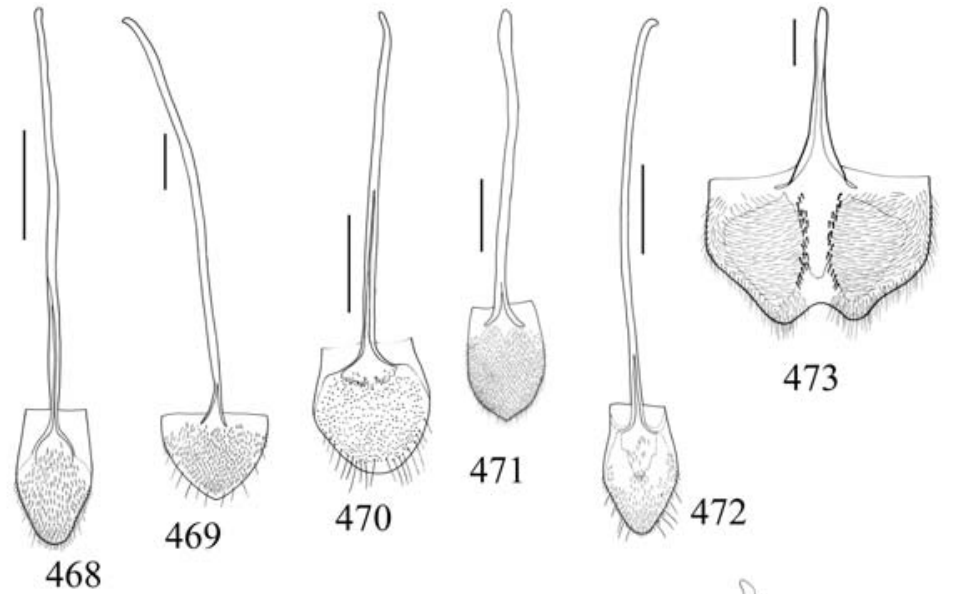

472
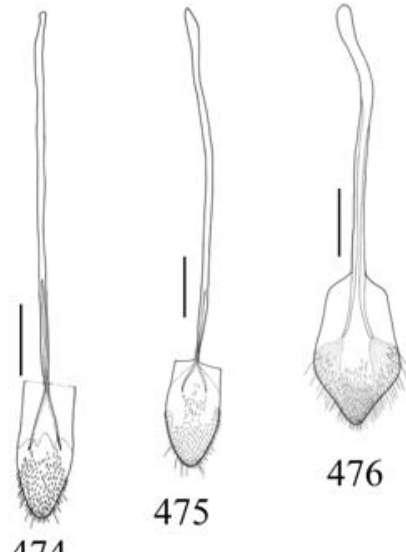

474
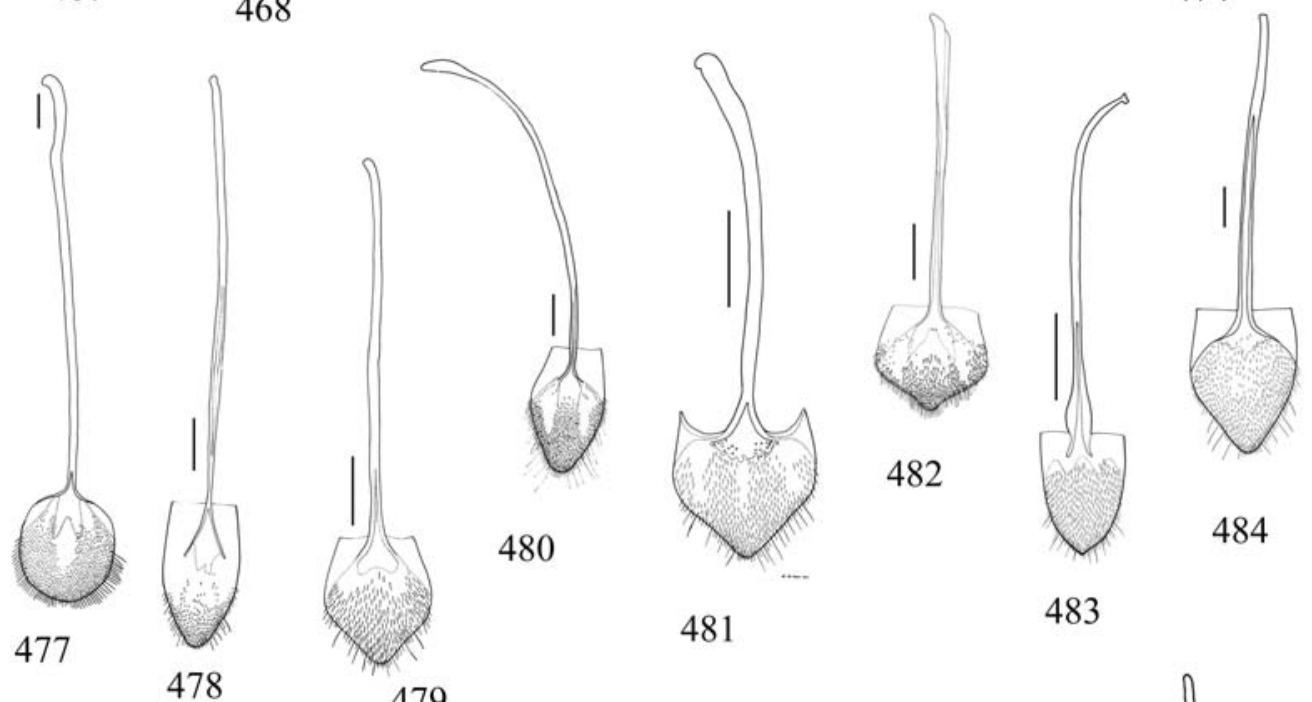

481

483
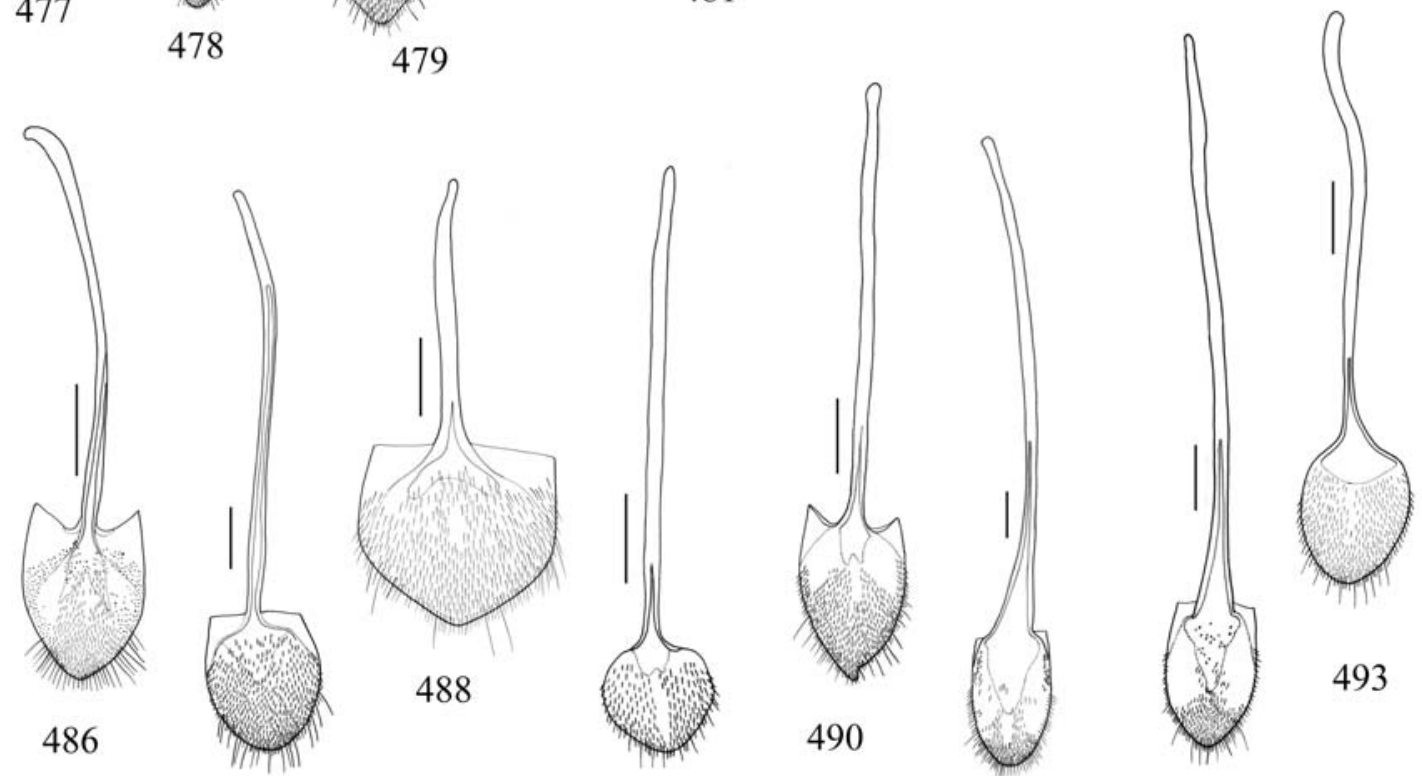

489

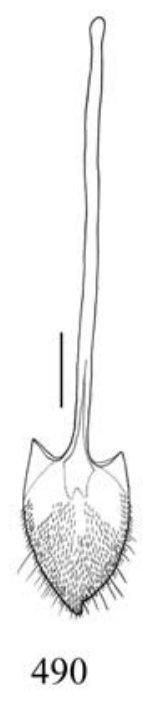

491

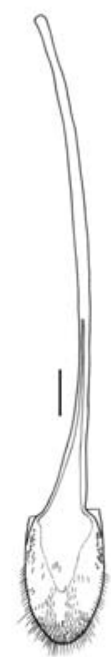

492
485
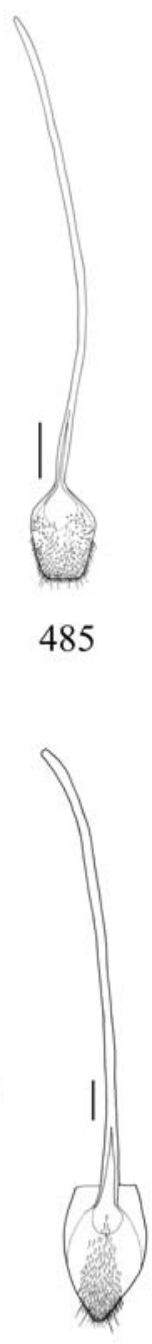

494

Figs 467-494. Sternite 8 of female: 467, Achrestus flavocinctus; 468, Achrestus venustus; 469, Anchastus digittatus; 470, Atractosomus flavescens; 471, Blauta cribraria; 472, Catalamprus angustus; 473, Chalcolepidius zonatus; 474, Crepidius flabellifer; 475, Crepidius resectus; 476, Ctenicera silvatica; 477, Cyathodera longicornis; 478, Dicrepidius ramicornis; 479, Dipropus factuellus; 480, Dipropus laticollis; 481, Lampropsephus cyaneus; 482, Loboederus appendiculatus; 483, Melanotus spernendus; 484, Pantolamprus mirabilis; 485, Physorhinus xanthocephalus; 486, Proloboderus crassipes; 487, Propsephus cavifrons; 488, Pseudolophoeus guineensis; 489, Rhinopsephus apicalis; 490, Sephilus frontalis; 491, Singhalenus gibbus; 492, Singhalenus taprobanicus; 493, Spilus atractomorphus; 494, Trielasmus varians. Bars $=1$ mm, except figs. $469,479,484,485,487-489,491,494=5 \mathrm{~mm}$, figs. $472,474,475,477,478,481,486,493=10 \mathrm{~mm}$. 
Basilewsky, 1958, P. (Xantholamprus) ligneus Candèze, 1896, P. menieri Girard, 1992, P. mirabilis Candèze, 1896 (= $P$. bennigseni Schwarz, 1896, = P. insignis Fleutiaux, 1902), $P$. monardi Fleutiaux, 1935b, P. neavei Girard, 2003, P. niger Fleutiaux, 1935b, P. nigripes Quedenfeldt, 1886 (=Var. hohanchaboti Fleutiaux, 1925, = Pantolamprus RohanChaboti Fleutiaux, 1925, = Var. obscurus Girard, 2003), P. plasoni Candèze, 1896, P. perpulcher (Westwood, 1842) (=Ampedus auricollis Hope, 1843, =Ampedus auripennis Hope, 1843, Ampedus cyanicollis Hope, 1843, =Ampedus cyanocephalus Hope, 1843, =Ampedus iris Hope, 1843, =Ampedus savagei Hope, 1843, =Var. garnieri Girard, 2003), P. (Xantholamprus) praeustus Fleutiaux, 1935b, $P$. purpureus Schwarz, 1899, P. rufangulus Fleutiaux, 1902 (= Var. paulyi Girard, 2003, = Var. rufoviridis Girard, 2003, = Var. cyaneus Girard, 2003), P. ruficollis Fleutiaux, 1902, P. rufipes Harold, 1878, P. savagei (Hope, 1843)(= Pantolamprus perpulcher var. savagei; Candèze, 1859, P. nitens Candèze, 1859), P. (Xantholamprus) sulcicollis Schwarz, 1896 (= P. plasoni Candèze, 1896), $P$. tanzanicus Girard, 1992 and P. terminatus Fleutiaux, 1935c. It is widely recorded from Africa (Guiné Bissau, Sierra Leone, Liberia, Ivory Coast, Ghana, Cameroon, Congo, Guiné, Gabon, Democratic Republic of the Congo, Malawi, Tanzania, Angola, Zambia, Mozambique,South Africa).

The Pantolamprus species included in this analysis form a monophyletic group characterized by homoplasies, 18(1) labrum semicircular, 24(3) galea bilobed and 25(4) setae of galea simple and spatulate. It is the sister-group of ((Achrestus flavocinctus)(Dayakus angularis)).

\section{Pantolamprus (Xantholamprus) ligneus Candèze, 1896} (Figs. 32, 233, 436, 437).

Pantolamprus ligneus Candèze, 1896: 21; Schenkling, 1925: 74 (cat.). Pantolamprus (Xantholamprus) ligneus; Fleutiaux, 1935c.

Length: 16-18 mm. General integument brown with elytra yellow. Pubescence golden, long and moderately dense, yellow on elytra. Frons carinate, wider than long; convex; flattened anteriorly; anterior margin prominent; punctuation moderately coarse and dense. Nasal wider than long. Antennae (Fig. 32) with 11 antennomeres; in male 0.8 antennomere longer than hind angles of pronotum; wide and serrate; scape shorter than eye; 2nd antennomere globular; 3rd triangular, wider than long, shorter than 4th; last narrowed at apex. Labrum semicircular with long setae. Mandibles wide with one apical and one subapical tooth. Last maxillar palpomere with securiform apex. Pronotum (Fig. 233) wider than long, narrowed anteriad; strongly convex, grooved longitudinal medially; lateral margins carinate; anterior margin slightly notched; hind angles wide, backwardly directed and weakly carinate; median basal tubercle flat; punctuation fine and dense, coarse on anterior angles and near anterior margin. Prosternal channel long. Prosternal spine very wide with subapical tooth. Borders of mesosternal cavity raised at base and vertical. Tibial spurs long; tarsomeres 1-3 lamellate beneath. Scutellum elongate with posterior margin rounded and lateral margins notched. Elytra convex, narrowed on distal third; striae coarse- and deeply punctuate and grooved; interstices equal and flat.

Male. Aedeagus (Figs. 436, 437) elongate; basal piece shorter than parameres; parameres separate ventrally; median lobe moderately narrowed near middle, constricted at apex; slightly longer than parameres; subapical region of parameres securiform rounded.

Material examined. [ANGOLA]. Ex-typis; col. R. I. Sc. N. B. Congo Portugais, ex-coll. Candèze, 2 Lectotype M (ISNB).

\section{Pantolamprus (Pantolamprus) mirabilis Candèze, 1896}

(Figs. 33, 83, 170, 234, 317, 484, 509, 510).

Pantolamprus mirabilis Candèze, 1896: 20; Fleutiaux, 1919: 39; Schenkling, 1925: 75 (cat.)

Pantolamprus bennigseni Schwarz, 1896:89.

Pantolamprus insignis Fleutiaux, 1902: 115.

Length: $18.0 \mathrm{~mm}$. General integument orange with head, antennae and scutellum black and elytra metallic blue. Pubescence moderately long and dense, ferrugineous on orange integument and black on black and blue integument. Frons carinate, wider than long, convex, flat anteriorly; anterior margin wide and slightly rounded, slightly prominent surpassing nasal; punctuation moderately coarse and dense. Nasal wider than long. Antennae (Fig. 33) with 11 antennomeres; wide and serrate in female; scape shorter than eye; $2^{\text {nd }}$ antennomere globular, $3^{\text {rd }}$ triangular elongate, slightly shorter than $4^{\text {th }}$, last narrowed at apex. Labrum (Fig. 83) semicircular with long setae. Mandibles robust, with one apical and one subapical tooth; penicillus formed by short setae disposed in whole mesal area; molar area well developed; dorsal region with carina and moderately long setae. Maxillae (Fig. 170): galea bilobed with simple and spatulate setae; last palpomere securiform. Labium: prementum with setae in front of palpi; postmentum with two long setae and several moderately long. Pronotum (Fig. 234) as long as wide, narrowed anteriad; moderately convex; lateral margins carinate; anterior margin notched; hind angles backwardly directed, carinate; median basal tubercle flat; punctuation moderately coarse and moderately dense, finer near base. Prosternal channel long. Prosternal spine widened apicad, with subapical tooth. Borders of mesosternal cavity raised at base and vertical. Metacoxal plate narrowed laterally; free margin straight. Tibial spurs long; tarsomeres 1-3 lamellate beneath. Scutellum elongate with posterior margin rounded and lateral margins notched. Elytra moderately convex, narrowed on distal third; striae coarsely punctuate; interstices equal and flat.

Female. Tergite 8 (Fig. 317) subtriangular, densely setous. Sternite 8 (Fig. 484) subpentagonal with short setae, longer at margins; spiculum gastrale 2.95 times sternite length. Ovipositor with stylus; bursa copulatrix (Figs. 509, 510) with 5 spiny areas, some disposed star-like.

Material examined. ZAMBIA. 1400 m, Mazabuka, 1 ex. (MZSP) 


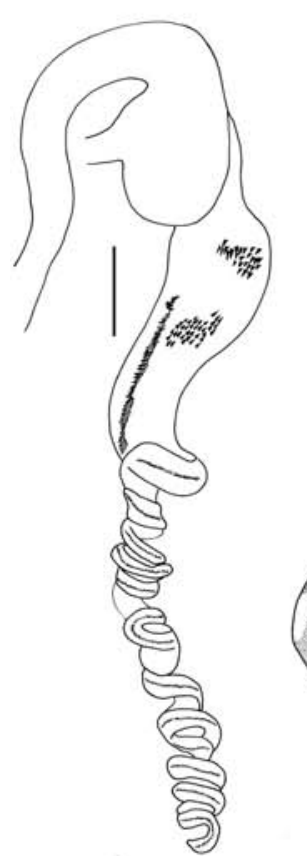

495
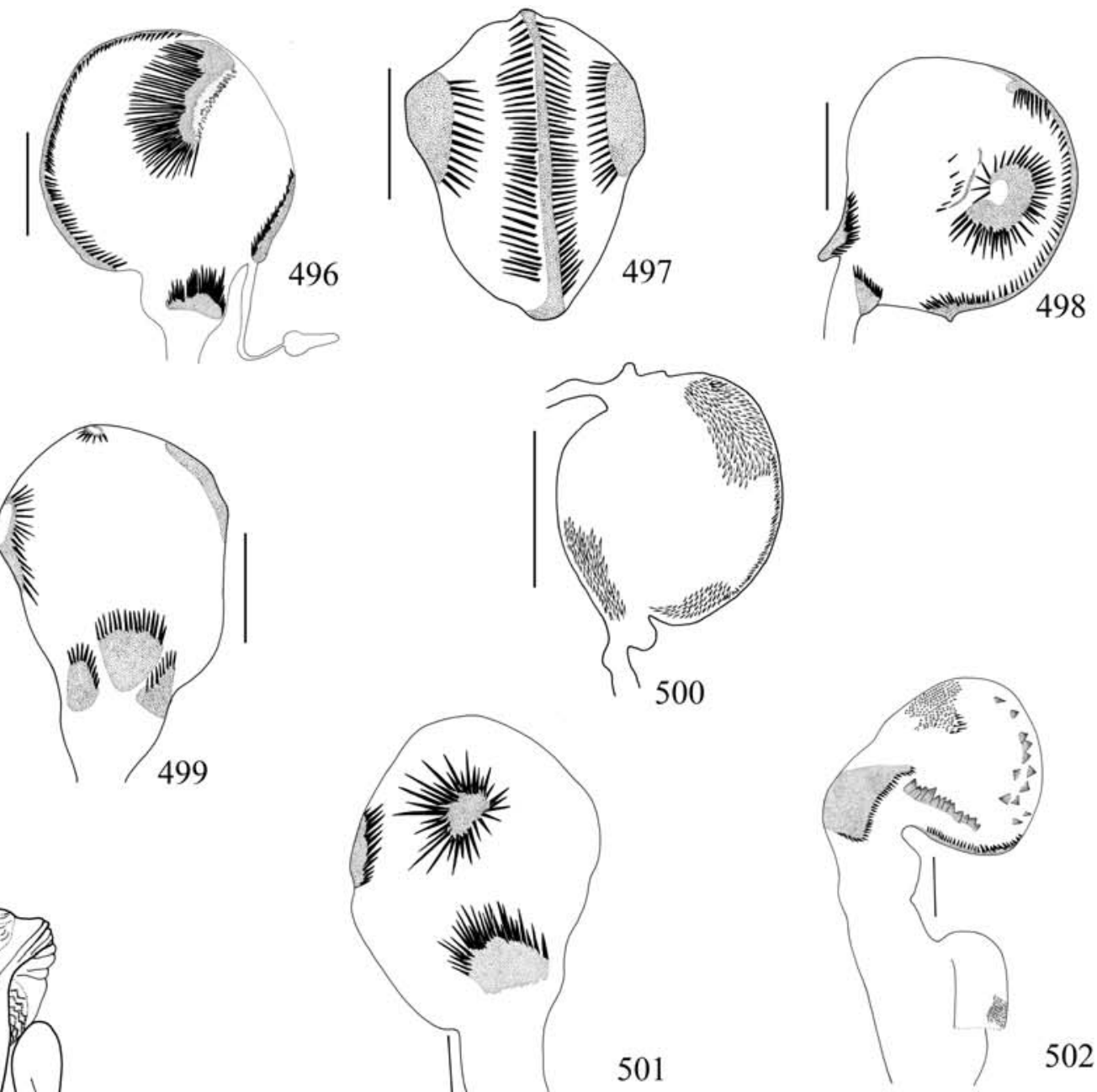

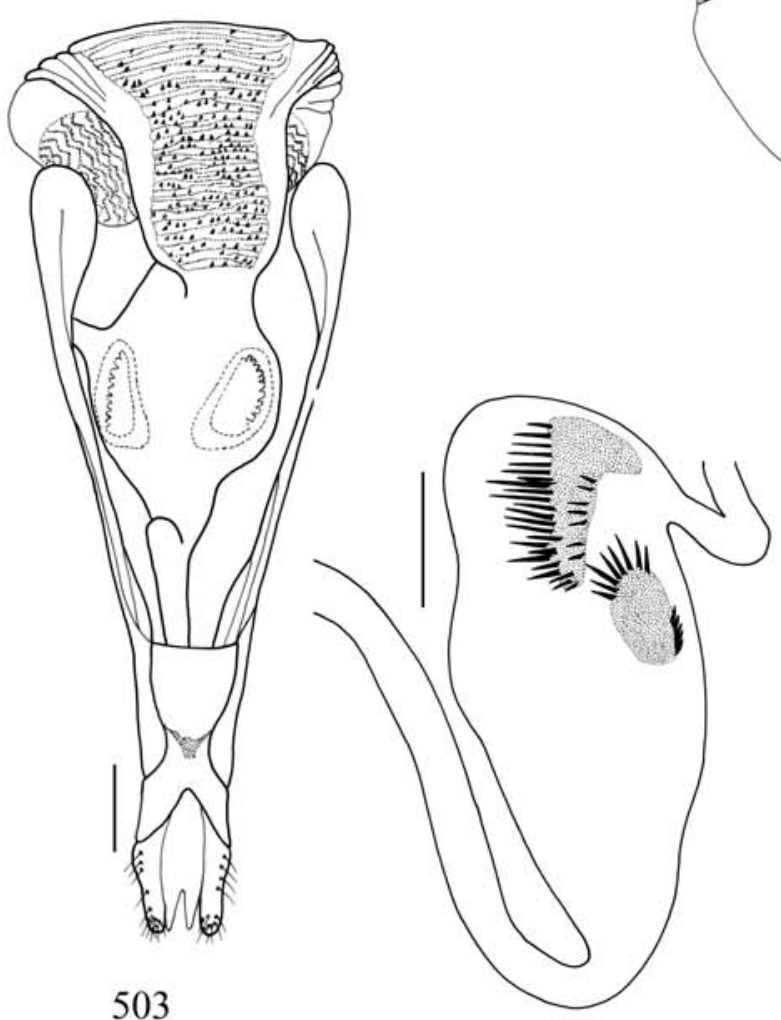

504

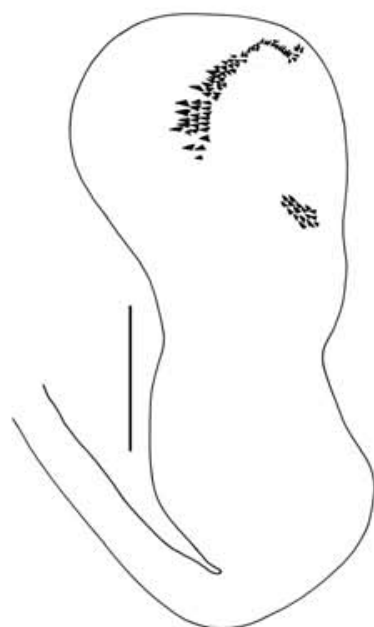

505

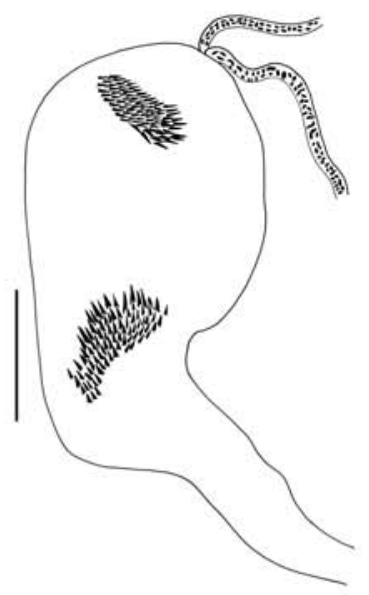

506

Figs. 495-506. Bursa copulatrix: 495, Anchastus digittatus; 496, Achrestus flavocinctus; 497-499, Atractosomus flavescens (D, L, V); 500, Blauta cribraria; 501, Calopsephus apicalis; 502, Catalamprus angustus; 503, Chalcolepidius zonatus; 504, Crepidius flabellifer; 505, Crepidius resectus; 506, Dicrepidius ramicornis. Bars $=1 \mathrm{~mm}$ except fig. $495=5 \mathrm{~mm}$, figs. 501, $502=2 \mathrm{~mm}$, figs. 504, $505=0.5 \mathrm{~mm}$. 
Pantolamprus (Pantolamprus) perpulcher Westwood, 1842 (Figs. 34, 84, 141, 142, 171, 181, 199, 235, 438, 439).

Ampedus perpulcher Westwood, 1842:205.

Pantolamprus perpulcher Candèze, 1859: 17; Schenkling, 1925: 75 (cat.). Ampedus auricollis Hope, 1843: 365.

Ampedus auripennis Hope, 1843: 365.

Ampedus cyanicollis Hope, 1843: 365.

Ampedus cyanocephalus Hope, 1843: 365.

Ampedus iris Hope, 1843: 365.

Length: $16.5 \mathrm{~mm}$. General integument black with legs, pronotum, hypomera and a narrow anterior band of prosternum yellow; elytra and head with metallic blue shine. Pubescence moderately long and dense, black dorsally and whitish ventrally. Frons carinate, wider than long, convex, prominent medioanteriorly surpassing nasal in short area; anterior margin strongly rounded; punctuation moderately coarse and dense. Nasal wider than long. Antennae (Fig. 34) with 11 antennomeres; in male not reaching hind angles of pronotum; serrate; scape shorter than eye; $2^{\text {nd }}$ antennomere globular, $3^{\text {rd }}$ triangular, as wide as long, shorter than $4^{\text {th }}$, last narrowed at apex. Labrum (Fig. 84) semicircular with long setae. Mandibles (Figs. 141, 142) robust, with one subapical tooth; penicillus formed by short setae disposed in whole mesal area; molar area well developed; dorsal region with carina and moderately long setae. Maxillae (Fig. 171): galea bilobed with simple and spatulate setae; last palpomere securiform. Labium (Fig. 181): prementum with setae in front of palpi; postmentum with two long setae and several short. Pronotum (Fig. 235) as long as wide, slightly narrowed anteriad; strongly convex; lateral margins carinate; anterior margin almost straight; hind angles backwardly directed, carinate; median basal tubercle flat; punctuation moderately coarse and dense, finer near base. Prosternal channel long. Prosternal spine widened apicad, with subapical tooth. Borders of mesosternal cavity (Fig.199) raised at base and vertical. Metacoxal plate narrowed laterally; free margin straight. Tibial spurs long; tarsomeres 1-3 lamellate beneath. Scutellum elongate with posterior margin rounded and lateral margins notched. Elytra convex, gradually narrowed at distal half; striae weakly punctuate; interstices equal and flat.

Male. Aedeagus (Figs. 438, 439) elongate; basal piece slightly shorter than parameres; parameres fused ventrally; median lobe narrow, slightly longer than parameres, slightly narrowed near middle and constricted at apex; apex of parameres securiform rounded.

Material examined. GHANA. Kumasi 1 ex. (MZSP).

Paraloboderus Golbach, 1990

Paraloboderus Golbach, 1990: 27.

Type-species: Paraloboderus glaber Golbach, 1990, by monotypy.

Golbach (1990) erected Paraloboderus to P. glaber from Argentina and Bolivia. According to him is probable that this species live together with termites or ants.
The genus Paraloboderus, monotypical, is recorded from the type-localities.

Paraloboderus glaber is characterized by homoplasies, $8(1)$ antennae of male serrate, 14(0) antennomere 3 longer than 4 and 68(1) apex of median lobe rounded. It is the sistergroup of ((Loboederus appendiculatus)(Proloboderus crassipes)).

Paraloboderus glaber Golbach, 1990

(Figs. 35, 236, 440).

Paraloboderus glaber Golbach, 1990: 28.

Length: 15.5-18.0 mm. General integument opaque and reddish-brown. Pubescence short, yellowish, stout and decumbent. Frons carinate, wider than long, pentagonal, very prominent and concave medioanteriorly; anterior margin surpassing nasal; punctuation moderately coarse and sparse. Nasal wider than long, triangular. Antennae (Fig. 35) with 11 antennomeres; in male 3 antennomeres longer than hind angles of pronotum; serrate in both sexes; scape shorter than eye; $2^{\text {nd }}$ antennomere globular; $3^{\text {rd }}$ triangular elongate, slightly longer than $4^{\text {th }}$; last narrowed at apex. Labrum semi-elliptical with distal margin rounded. Last maxilar palpomere widened apicad. Pronotum (Fig. 236) wider than long, narrowed anteriorly; moderately convex; slightly grooved longitudinal medially; lateral margins incompleteley carinate; anterior margin prominent at middle; hind angles backwardly directed and carinate, internal margin downwardly directed; median basal tubercle indistinct; punctuation moderately coarse and dense. Prosternal channel absent. Prosternal spine with rounded apex and subapical small lobe. Borders of mesosternal cavity narrow and declivous. Metacoxal plate narrowed laterally; free margin straight. Tibial spurs long; tarsomeres 1-3 with tiny lamellae beneath. Scutellum triangular elongate with rounded angles. Elytra very elongate, narrowed near apex; lateral margins forming brim; striae coarsely punctate; interstices slightly convex.

Aedeagus (Fig. 440) (adapted from Golbach, 1990): elongate; parameres longer than basal piece; subapical region of parameres slitly laterally; apex of parameres almost straight; median lobe moderately longer than parameres with lateral margins almost straight and apex rounded.

Material examined (5 male paratypes). ARGENTINA. Santiago del Estero, C. Jaime, 24.XI.1948, col. F. Lema (IMLA); Santiago del Estero, La Banda, 30.X.1946, col. Briones (IMLA); Tucuman, Dpto. Burruyacú, Siete de Abril, Represa, 10.I.1982, col. R. Golbach (IMLA). BOLIVIA. Cabeza, Santa Cruz, II.47, Peredo (IMLA); San Miserato, Chiquitos, Santa Cruz, 1000 m, 11.II.1958, Monrós (IMLA).

Proloboderus Fleutiaux, 1912

Proloboderus Fleutiaux, 1912: 264 Schenkling, 1925: 82 (cat.); Blackwelder, 1944: 298 (cat.).

Type species: Proloboderus crassipes Fleutiaux, 1912, designated by Hyslop, 1921 by monotypy. 

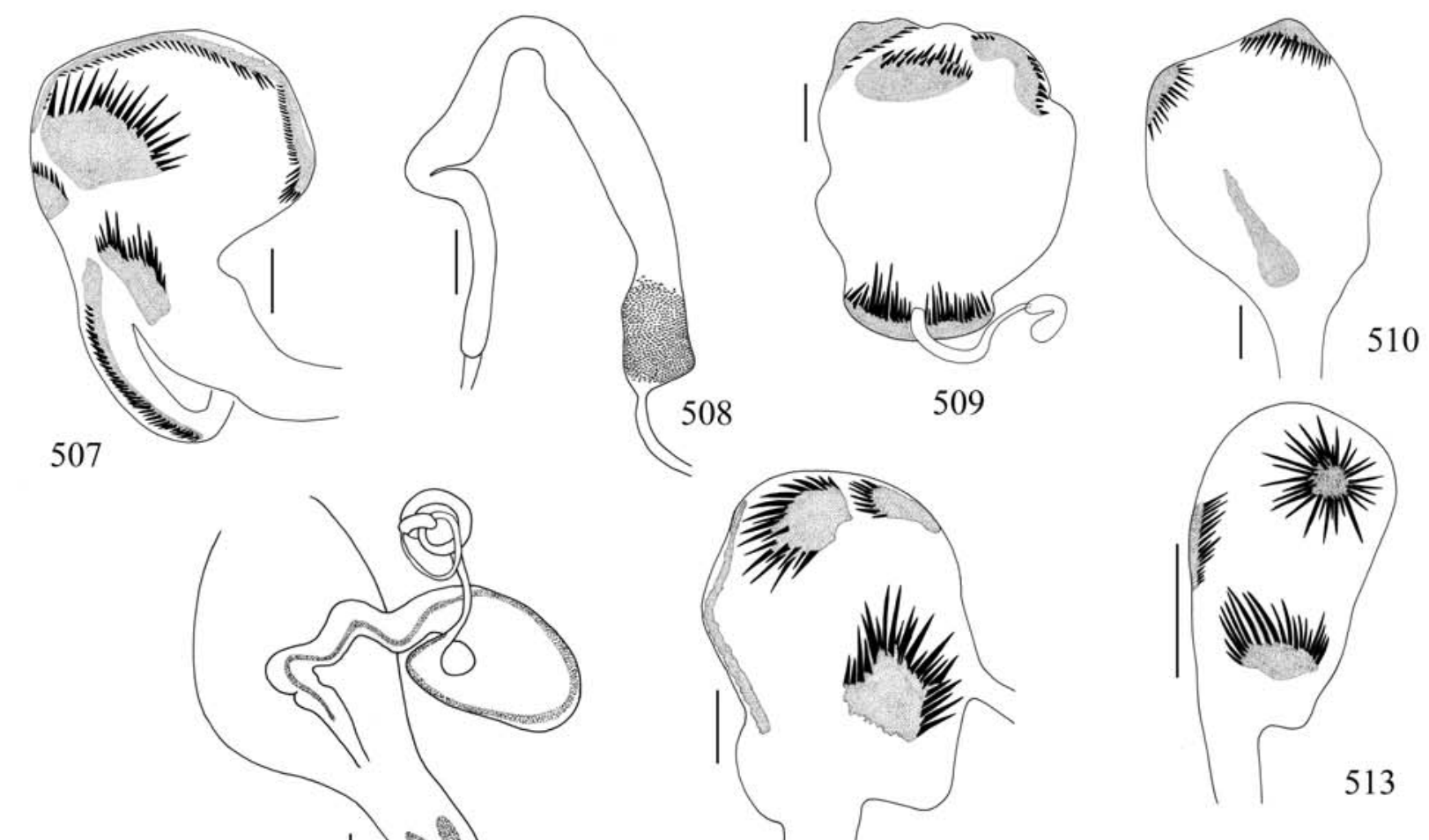

509
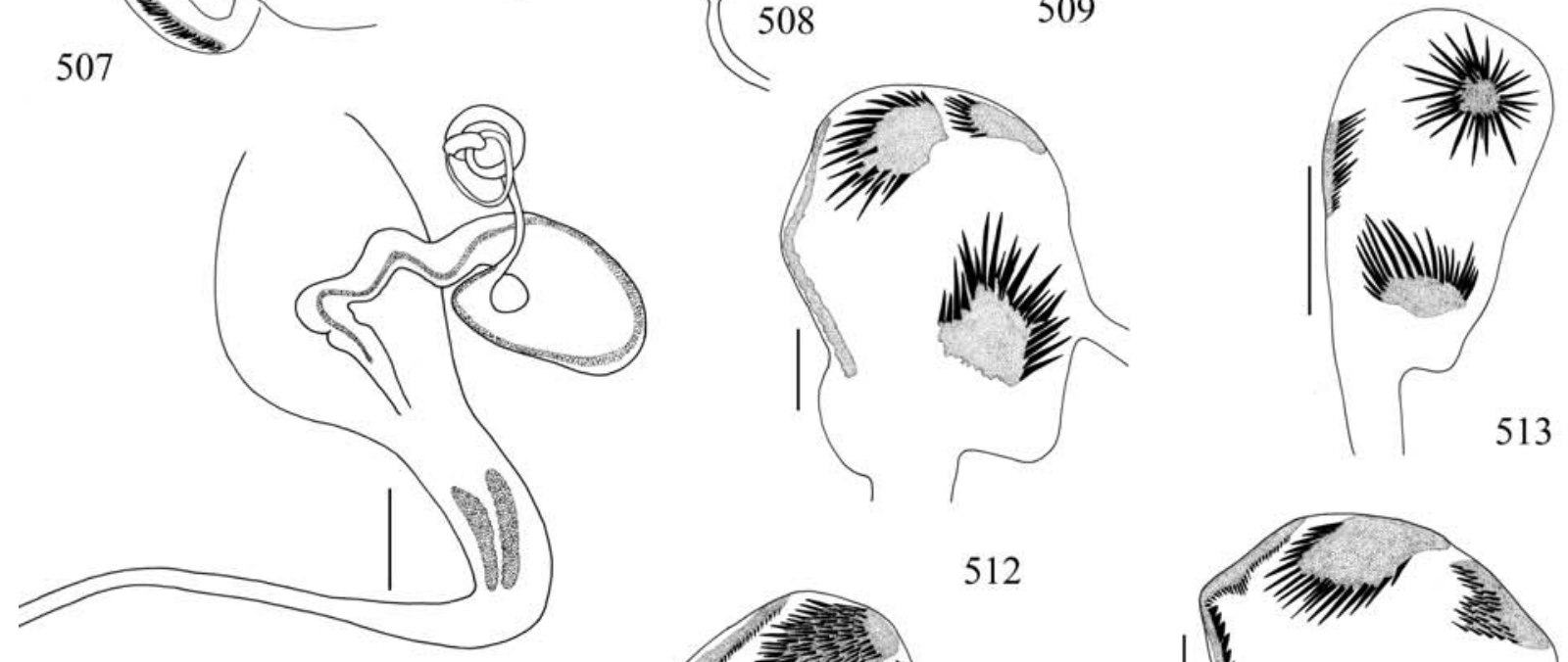

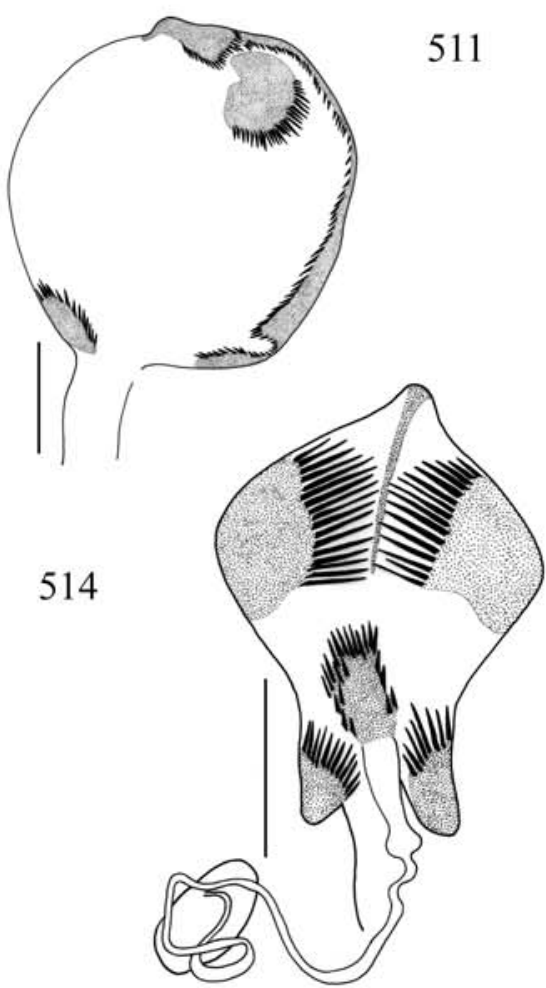

517

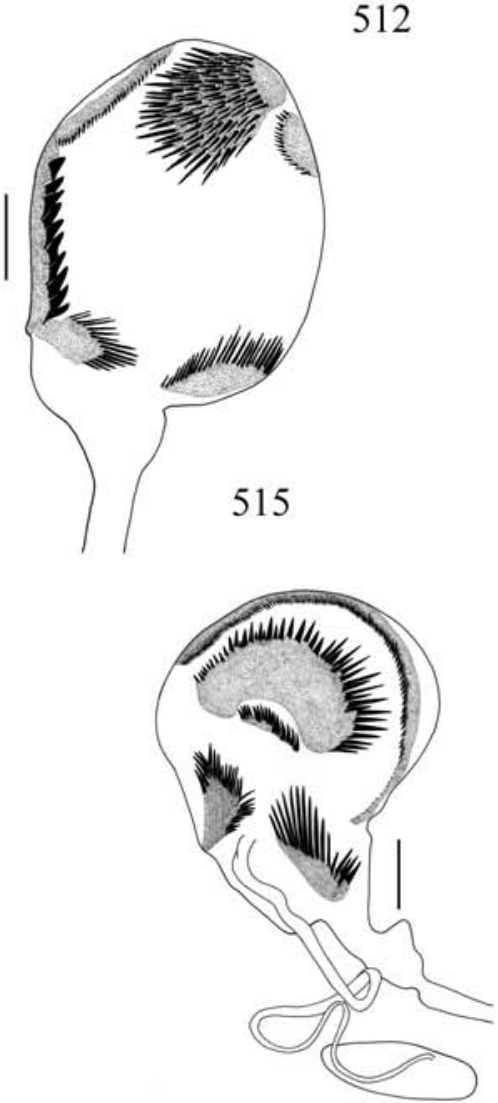

518
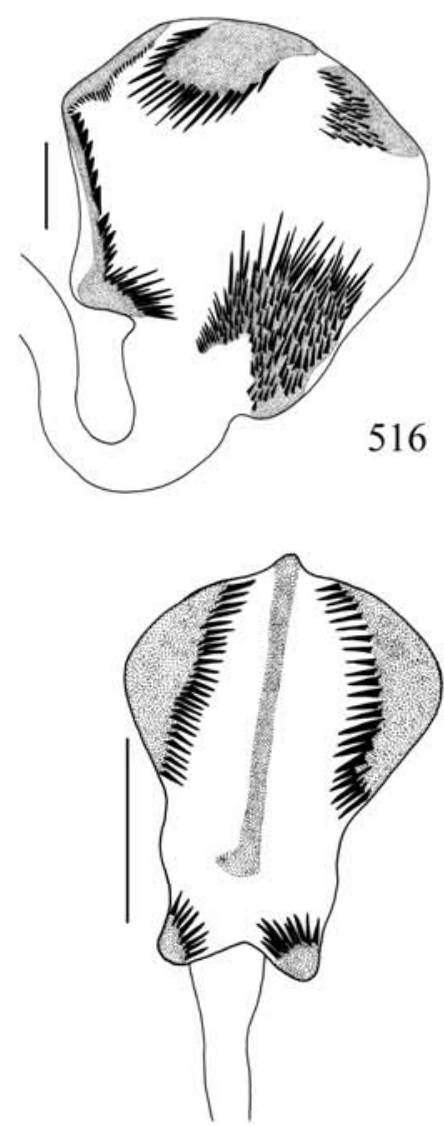

519

Figs. 507-519. Bursa copulatrix: 507, Lampropsephus cyaneus; 508, Melanotus spernendus; 509, 510, Pantolamprus mirabilis (D, V); 511, Physorhinus xanthocephalus; 512, Propsephus cavifrons; 513, Rhinopsephus apicalis; 514, Sephilus frontalis; 515, Singhalenus gibbus; 516, Singhalenus taprobanicus; 517-519, Spilus atractomorphus (D, L, V). Bars $=1 \mathrm{~mm}$, except fig. $507=0.5 \mathrm{~mm}$, figs. 509-513, 515= $5 \mathrm{~mm}$, fig. $516=2 \mathrm{~mm}$. 
Fleutiaux (1912) erected Proloboderus to P. crassipes from Santiago del Estero (Argentina). According to him, this genus is similar to Loboederus, but with hind angles of pronotum normal.

Schenkling (1925) and Blackwelder (1944) catalogued one species to this genus.

The genus Proloboderus, monotypical, is recorded from Argentina.

Proloboderus crassipes is characterized by synapomorphies, 12(1) antennomere 2 transverse, 13(2) antennomere 3 of male subtrapezoidal and 38(2) femur very widened, and by homoplasies, 8(4) antennae of male serrate in both sides and 66(4) median lobe 1/3 longer than parameres. It is the sister-group of Loboederus appendiculatus.

Proloboderus crassipes Fleutiaux, 1912

(Figs. 37, 38, 86, 145, 146, 173, 183, 201, 300, 318, 329, $362,443,444,486)$.

Proloboderus crassipes Fleutiaux, 1912: 264; Schenkling, 1925: 82 (cat.); Blackwelder, 1944: 298 (cat.).

Length: 14.5-15.5 mm. General integument brownish, slightly reddish-brown. Pubescence yellowish, very long and dense; longer and denser on lateral margins of pronotum, antennae and tibiae. Frons carinate, wider than long, concave longitudinal medially; anterior margin prominent at middle and surpassing nasal; punctuation coarse and moderately dense. Nasal high, slightly wider than long. Antennae (Figs. 37,38 ) with 11 antennomeres; in male 3 antennomeres longer than pronotum; serrate in both sides; scape very wide and shorter than eye; antennomeres 2-10 transverse; $3^{\text {rd }}$ trapezoidal, shorter than $4^{\text {th }}$, last elliptical with apex slightly narrowed. Labrum (Fig. 86) semicircular and densely setous. Mandibles (Figs. 145, 146) elongate with one apical and one subapical small tooth; penicillus formed by short setae disposed in whole mesal area; molar area well developed; dorsal region with carina and moderately long setae. Maxillae (Fig. 173): galea with simple setae; last palpomere with widened apex. Labium (Fig. 183): prementum with long setae in front of palpi; postmentum with moderately long setae. Prothorax (Fig. 201): pronotum wider than long, slightly narrowed anteriad; slightly convex, slightly grooved medioanteriorly; lateral margins sinuous and carinate; anterior margin prominent at middle; hind angles slightly divergent and carinate; median basal tubercle indistinct; punctuation moderately coarse and sparse, absent on basal third. Prosternal channel absent. Prosternal spine with rounded apex. Borders of mesosternal cavity very narrow and slightly declivous. Metacoxal plate narrowed laterally; free margin straight. Femur very widened, tibiae flat an enlarged; tibial spurs long; tarsomeres 2-3 lamellate beneath. Scutellum elongate with posterior margin rounded. Elytra slightly convex; striae punctuate; interstices equal and flat.

Male. Tergite (Fig. 318) 8 slightly wider than long, slightly narrowed apicad, with anterior margin rounded; punctuate and marginate by setae; clothed with microtrichiae. Sternite 8 (Fig.
300) transverse, slightly narrowed to apex; almost totally dark; anterior margin notched at middle; anterior angles rounded; setae disposed on whole surface. Sternite 9 (Fig. 329): distal half abruptly narrowed to apex; punctuate at middle and setous on distal third. Tergite 9 (Fig. 362): anterior margin almost straight; punctuate laterally with a few setae near angles; tergite 10 narrow, shorter than 9; punctuate laterally and setous near middle. Aedeagus (Figs. 443, 444) elongate; basal piece slightly longer than parameres; parameres fused ventrally; median lobe slightly narrowed near middle, constricted at apex and slightly longer than parameres; subapical region of parameres slitted laterally.

Female. Tergite 8 subtriangular, translucent in a basal area, densely setous. Sternite 8 (Fig. 486) elongate narrowed apicad; with short setae near middle and long setae near margins; spiculum gastrale 3.10 times sternite length. Ovipositor with stylus; bursa copulatrix without spines or sclerotized pieces.

Material examined. ARGENTINA. Chaco de Santiago del Estero, Rio Salado, 10 exs. (MNHN); same locality; decembre; collection Wagner; Proloboderus crassipes Fleut. Type collection Fleutiaux; Bull. Soc. Ent. Fr. 1912, p. 264, coll. Fleutiaux, 1 ex. (MNHN).

\section{Propsephus Hyslop, 1921}

Psephus Candèze, 1859: 9, 19; 1891: 50 (cat.); Schwarz, 1906: 61, 79; Fleutiaux, 1919: 38, 42; 1935a: 201.

Atractodes Erichson, 1843: 294.

Heterocrepidius Lacordaire, 1857: 110.

Subg. Campylopsephus Schwarz, 1899: 65; 1906: 79, 82.

Propsephus Hyslop, 1921: 666; Schenkling, 1925: 92 (cat.); Fleutiaux, 1935a: 204; Burgeon, 1947: 47; Girard, 1971: 593; Girard, 2003a: 469.

Type-species: Psephus beniniensis Candèze, 1859, designated by Hyslop, 1921.

Candèze (1859) erected Psephus to 16 species from Africa, 11 new species and 6 transferred from Atractodes, Dicrepidius or Heterocrepidius. He characterized the genus and presented a key to species. In 1891 he catalogued 74 species to this genus (66 African and 8 Oriental).

Schwarz (1899) erected the subgenus Campylopsephus to include the species with hind angles of pronotum curved innerly. However Basilewsky (1958) considered that this character does not justify the proposition of a new subgenus.

Schwarz $(1899,1901)$ transferred the following species to Olophoeus: Psephus attenuatus, $P$. granulipennis, $P$. guineensis, $P$. mechowi, P. melancholicus $(=P$. paralleus $)$ and P. radula. In 1906 included 114 species in Psephus: 104 into subgenus Psephus and 10 into subgenus Campylopsephus.

Girard (1971) transferred P. attenuatus and $P$. guineensis to Pseudolophoeus Girard, 1971. In 1972 he transferred P. invenustus to tribe Odontonychini. In 1991b he replaced the species transferred to Olophoeus by Schwarz in its original genus.

Blair (1927) described Psephus aenescens and stated that this species is very near to $P$. (Ischiodontus) hawaiiensis Candèze. According to him, "It is, perhaps, doubtful whether 
this insect should be placed in Psephus or in Ischiodontus, the two genera being scarcely separable. Schwarz in Wystman, 'Genera Insectorum', retains Ischiodontus with the exception of I. hawaiiensis, for American forms, Psephus for African and Oriental. Probably the new species, with hawaiiensis, would be more naturally placed with the Polynesian group of Psephus. Incidently it may be noted that, through an unfortunate error in labelling, the name hawaiiensis is quite inappropriate, the species occurring in Samoa, not the Sandwich Islands"

Hyslop (1921) give Propsephus, new name for Psephus Candèze, 1859, preoccupied by a genus of Coleoptera (Psephus Kirby, 1826). He also designated Psephus beniniensis Candèze as type-species.

Schenkling (1925) catalogued 172 species to this genus.

Fleutiaux (1932) treating of the faune of Mozambique, described Propsephus lesnei and recorded P. bucculatus Candèze, 1859, $P$. oberthuri Candèze, 1881 and $P$. granulipennis Candèze, 1859 to this region. In 1935a, verified the ambiguity of the characters that define the genus and that the genotype choose by Hyslop ( $l$. c.), the first cited by Candèze, 1859, was not representative. He proposed replace Psephus beniniensis Candèze by Psephus eliminatus Candèze because the later represents much better the generic characters enumerate by Candèze. He also transferred Ischiodontus pedestris Gerstaecker to Propsephus. In 1935b described 17 new species.

Van Zwaluwenburg (1936) widened the geographical distribution of $P$. compactus Van Zwaluwenburg.

Quelle (1955) presented an illustration of the bursa copulatrix of Propsephus elimatus Candèze, 1859, represented by long spines, similar to material examined.

Basilewsky (1958) redescribed the genus and divided the 100 species into two Sections, based on the $3^{\text {rd }}$ antennomere size. He followed Fleutiaux (1935a) and considered Psephus eliminatus Candèze, 1859 as type-species of the genus, and stated: "Espèce-type: Psephus eliminatus Candèze, 1859, fixée par Fleutiaux en 1935". He described 59 new species and enumerated other 41 , including a brief redescription, geographical distribution and informations about the type material of each one.

Van Zwaluwenburg (1959) designated the Lectotype of $P$. hawaiiensis (Candèze, 1833) (from ISNB), restored its specific status and considered Psephus euaensis Schwarz, 1902 as its synonym. Also designated as neotype of the Psephus euaensis, one specimen from DEI collection because the material of Elateridae in the Godeffroy Museum (where Schwarz's type was deposited) was destroyed during the war. This specimen in the DEI appears to him, to have been original Schwarz's material not deposited in the Godeffroy Museum. He commented that in 1928 he considered P. hawaiiensis as synonym of P. tongaensis because the types were not available. He also enumerated the differences between the two species. Related to $P$. major (Candèze, 1878) he commented that the type is said to have been in the Godeffroy Museum, destroyed during the war. He examined two females from Samoa (from
DEI) and did not see any specimen which could be the type. According to him, P. major is known only from Samoa, where it is very common, and the original type-locality, Fiji, probably is erroneous. He also designated the neotype of Psephus rufipes Schwarz, 1902 from DEI. He considered P. vitiensis Van Zwaluwenburg, 1940 as synonym of $P$. tongaensis (Candèze, 1878) and designated the Lectotype of the latter (from ISNB). He also commented the confusion of the type of $P$. vitiensis with $P$. tongaensis. He presented an identification key to 7 species of Propsephus from Mid-Pacific and the illustration of aedeagus of Propsephus euaensis (Schwarz, 1901) and $P$. tongaensis (Candèze, 1878).

According to Girard (1971), this genus is widely represented in "Afrique Noire". He recorded 21 species from Lamto (Côte d'Ivoire), from which 10 are new species. In 1991b treating of the Propsephus afrotropical studied by Candèze, he presented the new combination of three species of Olophoeus: Propsephus garnulipennis (Candèze, 1878), P. parallelus (Candèze, 1859) and $P$. radula (Candèze, 1896). He also designated the lectotypes of 27 species of Propsephus.

Van Zwaluwenburg (1934) described Propsephus compactus.

Fleutiaux (1945) described P. lepesmei and P. doualaensis.

Laurent (1965) presented a brief historical about the genus and, about the type-species, stated that Hyslop (1921) designated Psephus beniensis Candèze, but this species has $3^{\text {rd }}$ antennomere equal $4^{\text {th }}$, grave exception of diagnostic character of the genus, and Fleutiaux (1935a) changed the typespecies to Psephus elimatus Candèze. He also presented a key and the geographical distribution to two species recorded to that area, $P$. cavifrons Erichson, 1834 and $P$. puberulus Boheman, 1851.

Cobos (1970) erected a subgenus, Psephodes, and presented a key to two subgenus (Psephodes and Propsephus). He also described 18 species and recorded 12 from "Republica do Congo".

Girard (1974a) described 7 species of Propsephus; in 1975, P. amietoi; in 1976, 6 species from Africa; in 1980, 8 species of Ethiopian region. In 1989 described 6 species of Afrotropical Propsephus housed in the Musée Royal de 1'Afrique Central in Tervuren. He also designated Lectotypes to 6 species (Psephus aspersus Candèze, 1896; P. brevipennis Candèze, 1859; $P$. dentatus Candèze, 1881; $P$. fulgidus Schwarz, 1901; P. morio Candèze, 1881; P. semipunctatus Schwarz, 1901), proposed 8 synonymies (Propsephus aspersus Candèze, $1896=P$. niveopilosus Cobos, 1970; Propsephus brevipennis Candèze, $1859=$ P. gaedikei Girard, 1971; Propsephus congoensis Basilewsky, $1958=$ P. vaneyeni Basilewsky, 1958; Propsephus dentatus Candèze, $1881=P$. vuattouxi Girard, 1971; Propsephus fulgidus Schwarz, $1909=$ P. hirsutus Basilewsky, 1958; Propsephus morio Candèze $=P$. girardi Girard, 1971; Propsephus olophoeoides Fleutiaux, 1918 $=P$. ziwanicus Fleutiaux, 1935; Propsephus semipunctatus Schwarz $=P$. diversecribratus Basilewsky, 1958) and 5 new combinations [tranferred from Olophoeus] (Propsephus bequaerti (Burgeon, 1947), P. brunnipennis (Schwarz, 1908), 
P. kigonseranus (Burgeon, 1947), P. russatus (Fairmaire, 1887), P. semiferrugineus (Schwarz, 1896)). In 1991a treating of the Elateridae from the Savanah of the Nimban mountains, described 11 new species and recorded three species by the first time to this region. In 1985 described P. zeijsti; in 1986 described 7 species; in 1996 described 6 species from Afrotropical region; in 2003a described 25 species and recorded 40 species from Nimba and also proposed a new combination, Propsephus aficanus.

The genus Propsephus is formed by about 380 species. It is widely recorded from Africa, Madagascar, Seychelles, Malaysia and Polynesia.

The Propsephus species included in this analysis do not form a monophyletic group. P. beniensis, the type-species, is characterized by only one homoplasy, $8(2)$ antennae of male subserrate. (P. beniensis)(P. cavifrons) form a tricotomy with Spilus.

Propsephus beniensis (Candèze, 1859)

(Figs. 39, 87, 147, 148, 238, 268, 301, 363, 445, 446).

Psephus beniensis Candèze, 1859: 21.

Propsephus beniensis; Hyslop, 1921: 667; Schenkling, 1925: 93 (cat.).

Length: $21 \mathrm{~mm}$. General integument reddish-brown; prothorax slightly darker. Pubescence yellowish, moderately long and dense. Frons carinate, longer than wide, concave medioanteriorly near anterior margin; anterior margin rounded and very prominent, surpassing nasal; punctuation coarse and dense. Nasal longer than wide. Antennae (Fig. 39) of male with 11 antennomeres; in male one antennomere longer than pronotum; slightly serrate; scape shorter than eye; $2^{\text {nd }}$ antennomere globular, $3^{\text {rd }}$ triangular elongate, shorter than $4^{\text {th }}$, last narrowed at apex. Labrum (Fig. 87) like narrow band with long setae. Mandibles (Figs. 147, 148) robust, with one apical and one subapical tooth; penicillus formed by short setae disposed in whole mesal area; molar area well developed; dorsal region with carina and moderately long setae. Maxillae: galea with simple setae; last palpomere securiform. Labium: prementum with setae in front of palpi; postmentum with two long setae and several moderately long. Pronotum (Fig. 238) slightly wider than long, narrowed anteriad; strongly convex; lateral margins carinate; anterior margin almost straight; hind angles long, slightly divergent and carinate; median basal tubercle flat; punctuation coarse, heterogeneous and dense. Prosternal channel long. Prosternal spine with subapical lobe. Borders of mesosternal cavity narrow and declivous. Metacoxal plate (Fig. 268) strongly narrowed laterally; free margin with small tooth. Tibial spurs long; tarsomeres 1-3 lamellate beneath. Scutellum elongate, slightly narrowed to apex with posterior margin rounded. Elytra convex, narrowed on distal third; striae deeply punctuate; interstices equal and flat.

Male. Tergite 8 subtriangular with distal margin rounded; punctuate and marginate by setae; clothed with microtrichiae. Sternite 8 (Fig. 301) translucent with narrow sclerotized transverse band near base; anterior margin straight with rounded angles; setae concentrate near angles. Sternite 9: distal half gradually narrow to apex; distal third setous. Tergite 9 (Fig. 363) strongly notched at middle; punctuate with setae concentrate near angles; tergite 10 longer than 9 with setae near apex. Aedeagus (Figs. 445, 446) elongate; basal piece shorter than parameres; parameres fused ventrally; median lobe slightly narrowed to apex and slightly longer than parameres; apex of parameres securiform, excavate anteriorly.

Material examined. ANGOLA. $30 \mathrm{Km} \mathrm{N}$ of Quiculungo, 1 ex. (MZSP)

Propsephus cavifrons (Erichson, 1843)

(Figs. 40, 88, 157, 239, 487, 512).

Atractodes cavifrons Erichson, 1843: 224.

Psephus cavifrons; Candèze, 1859: 25.

Propsephus bucculatus cavifrons; Schenkling, 1925: 93 (cat.).

Length: 18-19 mm. General integument reddish-brown. Pubescence whitish, short and moderately dense. Frons carinate, slightly longer than wide, concave medioanteriorly near anterior margin; anterior margin wide, slightly rounded and very prominent, surpassing nasal; punctuation coarse and dense. Nasal longer than wide. Antennae (Fig. 40) of female with 11 antennomeres; serrate; scape shorter than eye; $2^{\text {nd }}$ antennomere globular, $3^{\text {rd }}$ short and triangular, shorter than $4^{\text {th }}$, last narrowed at apex. Labrum (Fig. 88) semielliptical with long setae. Epipharynx (Fig. 157): membranous with two striate areas and two sclerites near base; two median bands of microtrichiae convergent at base; sensorial points near middle. Mandibles robust, with one apical and one subapical tooth; penicillus formed by short setae disposed in whole mesal area; molar area well developed; dorsal region with carina and moderately long setae. Maxillae: galea with simple setae; last palpomere securiform. Labium: prementum with setae in front of palpi; postmentum with two long setae and several moderately long. Pronotum (Fig. 239) slightly wider than long, narrowed anteriad; strongly convex; lateral margins carinate; anterior margin almost straight; hind angles, slightly divergent and carinate; median basal tubercle flat; punctuation coarse and very dense. Prosternal channel long. Prosternal spine with subapical lobe. Borders of mesosternal cavity narrow and declivous. Metacoxal plate strongly narrowed laterally; free margin with small tooth. Tibial spurs long; tarsomeres 1-3 lamellate beneath. Scutellum subpentagonal with posterior margin rounded. Elytra convex, narrowed on distal fourth; striae coarsely punctuate; interstices equal and flat.

Female. Tergite 8 subtriangular, densely setous. Sternite 8 (Fig. 487) elongate with distal margin rounded; densely clothed with short setae; spiculum gastrale 3.68 times sternite length. Ovipositor with stylus; bursa copulatrix (Fig. 512) with 6 spiny areas, some disposed star-like.

Material examined. NAMIBIA. (S. W. Africa), Okanhandja, 1 ex. (MNHN). SOUTH AFRICA. Transvaal [Province], 1 ex. (MNHN) 
Pseudolophoeus Girard, 1971

Pseudolophoeus Girard, 1971: 591; 2003a: 460.

Olophoeus (pars) Candèze, 1859:15; Schenkling, 1925: 87 (cat.).

Type-species: Olophoeus guineensis Candèze, 1881, original designation.

Girard (1971) erected Pseudolophoeus to include 8 species of Olophoeus Candèze (O. guineensis guineensis (Candèze, 1881), O. guineensis antennatus (Candèze), O. guineensis katanganus, Basilewsky, 1958, O. vrydaghi (Burgeon, 1947), O. cinnamomeus Schwarz, 1901, O. vandertichelei Burgeon, 1947, O. alternans Burgeon, 1947, O. quellei, Basilewsky, 1958), and perhaps, one more species (O. protensus Gerstaecker) that, according to him, needs to examine the type. He also redescribed Olophoeus guineensis and designated it as typespecies. In $1991 \mathrm{~b}$ presented a new combination of one species belonged to Olophoeus: Pseudolophoeus melancholicus (Candèze, 1881). In 2003a emphasized the diagnostic characters of the genus: antennae carinate from $3^{\text {rd }}$ to $9^{\text {th }}$ antennomeres, prosternal spine not strongly declivous innerly and last ventrite convex. He recorded $P$. guineensis to Nimba.

The genus Pseudolophoeus is formed by 10 species: $P$. alternans (Burgeon, 1947), P. cinnamomeus (Schwarz, 1901), P. guineensis antennatus (Candèze), $P$. guineensis guineensis (Candèze, 1881) (=Olophoeus guineensis; Schwarz, 1906), $P$. guineensis katanganus (Basilewsky, 1958), P. melancholicus (Candèze, 1881), P. protensus Gerst., 1884, P. quellei (Basilewsky, 1958), P. vandertichelei (Burgeon, 1947), $P$. vrydaghi (Burgeon, 1947). It is recorded from Africa (Senegal, Gambia, Guine Bissau, Sierra Leone, Liberia, Ivory Coast, Democratic Republic of Congo, South Africa).

Pseudolophoeus guineensis is characterized by synapomorphies, 21(5)mesal area of mandibles with one bilobed subapical tooth and 27(3) last palpomere cylindrical, and by homoplasies, 3(0) anterior margin of frons at nasal level, 4(4) median anterior region of frons downwards, 15(1) antennae of male 2.5-4.4 antennomeres longer than hind angles of pronotum, 16(0) longitudinal carina of antennae present, 19(1) anterior margin of labrum notched at middle, 25(2) setae of galea short bristle, 33(0) prosternal channel absent, 37(4) free margin of metacoxal plate with small tooth, 40(2) tibial spurs very long, 58(4) distal margin of tergite 9 of male slightly notched at middle and 67(0) lateral margins of median lobe almost straight. It belongs to a polytomy formed by Anoplischiopsis bivittatus, Olophoeus gibbus and Adiaphorus.

Pseudolophoeus guineensis (Candèze, 1881)

(Figs. 41, 89, 149, 150, 174, 184, 240, 302, 364, 447, 448, 488).

Psephus guineensis Candèze, 1881:27; 1891: 51 (cat.).

Olophoeus guineensis; Schwarz, 1906: 76; Schenkling, 1925: 87 (cat.). Pseudolophoeus guineensis; Girard, 1971: 591.

Length: 14-16 mm. General integument dark-brown.
Pubescence yellowish, moderately long and dense. Frons carinate, wider than long, convex and flat anteriorly; anterior margin slightly rounded, surpassing nasal in narrow band; punctuation moderately coarse and dense. Nasal wider than long. Antennae (Fig. 41) with 11 antennomeres; in male 3 antennomeres longer than hind angles of pronotum; serrate in male, subserrate in female; scape shorter than eye; $2^{\text {nd }}$ antennomere globular, $3^{\text {rd }}$ triangular, slightly shorter than $4^{\text {th }}$, last narrowed at apex; longitudinal carina present on antennomeres 3-7 or 3-8; carina weaker to apex direction. Labrum (Fig. 89) semielliptical with long setae; anterior margin notched at middle. Mandibles (Figs. 149, 150) narrow with one subapical bilobed tooth; penicillus formed by short setae disposed in whole mesal area; dorsal region with carina and moderadely long setae. Maxillae (Fig. 174): galea with bristle short setae; last palpomere cylindrical. Labium (Fig. 184): prementum with setae in front of palpi; postmentum with many long setae. Pronotum (Fig. 240) wider than long, slightly narrowed anteriad; strongly convex; lateral margins carinate; anterior margin almost straight; hind angles backwardly directed and carinate; median basal tubercle flat; punctuation moderately coarse and dense. Prosternal channel absent. Prosternal spine with small subapical lobe. Borders of mesosternal cavity declivous. Metacoxal plate strongly narrowed laterally; free margin with tooth. Tibial spurs very long; tarsomeres 2-3 lamellate beneath. Scutellum subtriangular elongate. Elytra strongly convex, slightly narrowed on distal third; striae punctuate and grooved; interstices punctuate, equal and flat.

Male. Tergite 8 elongate with distal margin rounded; punctuate and marginate by setae; clothed with microtrichiae. Sternite 8 (Fig. 302) translucent with basal transverse sclerite; anterior margin straight with rounded angles; setae concentrate near distal third. Sternite 9 slightly narrowed apicad; distal third setous. Tergite 9 (Fig. 364) densely punctuate; anterior margin slightly notched at middle, with setae near angles; tergite 10 as long as 9 , with setae distributed in almost whole area. Aedeagus (Figs. 447, 448) elongate, wide; basal piece shorter than parameres; parameres fused ventrally; median lobe slightly narrowed apicad with rounded apex, slightly longer than parameres; apex of parameres securiform.

Female. Tergite 8 transverse, slightly narrowed apicad, with anterior margin rounded; densely setous. Sternite 8 (Fig. 488) with narrowed and rounded apex; clothed by moderately long setae; spiculum gastrale 1.93 time sternite length. Ovipositor with stylus; bursa copulatrix without spiny areas.

Material examined. GHANA. 2 exs (MZSP). GAMBIA. 5 exs (MNHN). SENEGAL. Badi, 4 exs (MNHN). Casamance, 2 exs (MNHN). IVORY COAST. Bouake, Cap de Le Magnen, 1 ex. (MNHN). Dimbroko, 5 exs (MNHN). Lamto, 2 exs (MNHN). GUINEA. Ziela, NIMBA, 3 exs (MNHN).

Rhinopsephus Schwarz, 1906

Rhinopsephus Schwarz, 1906: 59, 82; Schenkling, 1925: 98 (cat.); Basilewsky, 1958: 470; Cobos, 1970: 183; Girard, 2003a: 464. 
Type-species: Psephus minor Candèze, 1881. Hyslop (1921) designated Psephus miliaris Schwarz, 1903, as type-species; Basilewsky (1958) synonymized it under Rhinopsephus minor (Candèze, 1881).

Schwarz (1906) erected the genus Rhinopsephus to 5 species from Psephus Candèze, 1859.

Hyslop (1921) designated Psephus milares Schwarz, 1903 as type-species.

Schenkling (1925) catalogued 6 species to this genus.

Basilewsky (1958) redescribed briefly the genus, described a new species, $R$. sylvaticus and considered Psephus miliaris Schwarz, 1903 (type-species designated by Hyslop) as synonym of $R$. minor (Candèze, 1882).

Cobos (1970) described two new species, $R$. reticulicollis and $R$. lucidulus and commented the similarities of this genus with Ischiodontus and Dicrepidius, and some doubts on the vality of Rhinopsehus. According to him, at that time, the genus was composed by 6 species besides 2 new species described by him.

According to Girard (1985) the genus Rhinopsephus Schwarz is exclusively afrotropical. It was composed by 10 species, 6 of which found at western Africa. He described two new species R. martini and R. balachowskyi; in 1985 (1986) described $R$. venustus. In 2003a commented that the genus is exclusively afrotropical; described two new species and recorded 5 others from Nimba.

The genus Rhinopsephus is formed by 13 species: $R$. apicalis (Schwarz, 1903), $R$. balachowskyi Girard, 1985, $R$. guineensis Girard, 2003, R. impressicollis (Schwarz, 1899)(=R. nasalis (Schwarz, 1902)), R. lamottei Girard, 2003, R. lucidulus Cobos, 1970, R. martini Girard, 1985, R. minor (Candèze, 1881)(=R. milaris (Schwarz, 1903), R. nigrifrons Schwarz, 1909, R. reticulicollis Cobos, 1970, R. submarmoratus (Schwarz, 1903), R. sylvaticus Basilewsky, 1958, R. venustus Girard, 1985(1986). It is recorded from Africa (Ivory Coast, Cameroon, Gabon, Democratic Republic of the Congo, Tanzania).

Rhinopsephus apicalis is characterized by homoplasies, $0(1)$ frons longer than wide, $6(0)$ ridge of nasal present, 7(1) nasal longer than wide, 9(4) antennae of female pectinate, 25(6) setae of galea thick and spatulate, 28(1) pronotum longer than wide and 69(2) apex of sternite 8 of female widely rounded. It forms a tricotomy with Calopsephus apicalis and Catalamprus angustus.

Rhinopsephus apicalis (Schwarz, 1903)

(Figs. 42, 43, 90, 156, 241, 269, 303, 365, 449, 450, 489, $513)$.

Psephus apicalis Schwarz, 1903: 48.

Rhinopsephus apicalis; Schwarz, 1906: 82; Schenkling, 1925: 98 (cat.).

Length: 8.5-10.0 mm. General integument dark-brown with prothorax and anterior $2 / 3$ of elytra yellow; pronotum with longitudinal median band dark-brown, wider frontally. Pubescence moderately long and dense, accompanying integument color dorsally, and whitish ventrally. Frons carinate, longer than wide, convex and slightly concave near anterior margin; anterior margin wide and rounded, prominent, surpassing nasal; punctuation coarse and very dense. Nasal (Fig. 156) longer than wide, with 2 longitudinal ridges. Antennae (Figs. 42, 43) with 11 antennomeres; in male 3 antennomeres longer than pronotum; serrate in male, roundly serrate in female; scape shorter than eye; $2^{\text {nd }}$ antennomere globular, $3^{\text {rd }}$ triangular, shorter than $4^{\text {th }}$, last elliptical; antennomeres 3-11 with longitudinal carina. Labrum (Fig. 90) semielliptical with long setae. Mandibles robust, with one apical and one subapical tooth; penicillus formed by short setae disposed in whole mesal area; molar area well developed; dorsal region with carina and moderately long setae. Maxillae: galea with thick and spatulate setae; last palpomere widened to apex. Labium: prementum with setae in front of palpi; postmentum with two long and several tiny setae. Pronotum (Fig. 241) longer than wide; strongly convex, grooved longitudinal medially, near base; lateral margins carinate; anterior margin straight; hind angles backwardly directed and carinate; median basal tubercle indistinct; punctuation moderately coarse and very dense. Prosternal channel long. Prosternal spine with subapical tooth. Borders of mesosternal cavity narrow and declivous. Metacoxal plate (Fig. 269) slightly narrowed laterally; free margin with well developed tooth. Tibial spurs very small; tarsomeres 2-3 lamellate beneath. Scutellum elongate with posterior margin rounded. Elytra convex, slightly narrowed on distal third; striae coarsely and deeply punctuate, grooved near base; interstices equal and flat.

Male. Tergite 8 elongate with distal margin rounded; punctuate and marginate by setae; clothed with microtrichiae. Sternite 8 (Fig. 303) translucent with very small basal transverse sclerite; anterior margin straight with rounded angles; setae concentrate near angles. Sternite 9: distal half slightly narrow to apex; distal third setous. Tergite 9 (Fig. 365): anterior margin strongly notched at middle, V-shaped; punctuate with setae concentrate near angles; tergite 10 longer than 9 with setae near apex. Aedeagus (Figs. 449, 450) elongate, wide; basal piece shorter than parameres; parameres fused ventrally; median lobe very narrow, widened near base, slightly longer than parameres; apex of parameres securiform and rounded.

Female. Tergite 8 subtriangular, densely setous. Sternite 8 (Fig. 489) rounded, narrowed at apex; clothed by moderately long setae; spiculum gastrale 4.63 times sternite length. Ovipositor with stylus; bursa copulatrix (Fig. 513) with 5 spiny areas, some disposed star-like.

Material examined. CAMEROON. (Kamerun), 1 ex. (MNHN). SIERRA LEONE. Rhobomp, 1 ex. (MNHN).

Semiotopsis Candèze, 1887

Semiotopsis Candèze, 1882: 188; 1891: 44 (cat.); Schwarz, 1906: 60, 74; Schenkling, 1925: 84 (cat.); Blackwelder, 1944: 298 (cat.).

Type-species: Semiotopsis ungulata Candèze, 1887, designated by monotypy. 
Candèze (1887) erected Semiotopsis to S. ungulata from "Nouvelle Grenade: Valle de Cauca". It was characterized especially by tarsomeres 2 and 3 lamellate, mesosternum distinct from metasternum and claws toothed.

Schenkling (1925) and Blackwelder (1944) catalogued one species to this genus.

The genus Semiotopsis, monotypical, is recorded from Colombia.

No specimen of this genus was examined but by original description it is possible to verify that it presents tarsomeres 2 and 3 lamellate indicating that it belongs to Dicrepidiina.

\section{Sephilus Candèze, 1878}

Sephilus Candèze, 1878: 108; 1891: 56; Schwarz, 1906: 60, 70; Schenkling, 1925: 82

Type-species: Sephilus frontalis Candèze, 1878, designated by monotypy.

Candèze (1878) erected the genus Sephilus to S. frontalis, from Borneo. According to him, $S$. frontalis should be included in Psephus or Elius, but he preferred put it in a new genus.

Schwarz (1906) included 3 species in the genus.

Schenkling (1925) catalogued three species to this genus.

Kishii (1999) studied the aedeagus of $S$. formosanus Schwarz, 1902 and described S. shibatai.

The genus Sephilus is formed by 4 species: S. formosanus Schwarz, 1902, S. frontalis Candèze, 1878, S. minor Schwarz, 1901, S. shibatai Kishii, 1999. It is recorded fromTaiwan, Malaysia, Borneo, Sumatra.

The Sephilus species included in this analysis form a monophyletic group, characterized by homoplasies, 2(0) anterior margin of frons declivous at middle, 25(0) setae of galea simple and 34(1) prosternal spine with rounded apex. It is the sister-group of ((Achrestus venustus)((Dicrepidius ramicornis)(Crepidius))).

Sephilus formosanus Schwarz, 1912

(Figs. 44, 91, 242, 270, 304, 366, 451, 452).

Sephilus formosanus Schwarz, 1912: 319; Schenkling, 1925: 82 (cat.).

Length: 11.5-12.0 mm. General integument reddish-brown; prothorax and head darker. Pubescence yellowish-white moderately long and dense. Frons carinate, as wide as long; convex; anterior margin wide and rounded, prominent, surpassing nasal; punctuation coarse and dense. Nasal longer than wide. Antennae (Fig. 44) of male with 11 antennomeres; 1.7 antennomeres longer than pronotum; serrate; scape shorter than eye; $2^{\text {nd }}$ antennomere globular, $3^{\text {rd }}$ triangular elongate, shorter than $4^{\text {th }}$, last narrowed at apex. Labrum (Fig. 91) like narrow band with long setae. Mandibles wide with one apical and one subapical tooth; penicillus formed by short setae disposed in whole mesal area; dorsal region with carina and moderately long setae. Maxillae: galea with simple setae; last palpomere securiform. Labium: prementum with setae in front of palpi; postmentum with two long and several moderately long setae. Pronotum (Fig. 242) wider than long, slightly narrowed anteriorly; moderately convex; convexity decreasing basad; grooved longitudinal medially, at base; lateral margins carinate; anterior margin straight; hind angles backwardly directed and carinate; median basal tubercle flat; punctuation coarse and dense. Prosternal channel long. Prosternal spine with narrowed apex. Borders of mesosternal cavity narrow and declivous. Metacoxal plate (Fig. 270) strongly narrowed laterally; free margin straight. Tibial spurs small; tarsomeres 1-3 lamellate beneath. Scutellum elongate with posterior margin rounded and lateral margins notched. Elytra moderately convex, narrowed on distal third; striae grooved; interstices equal and flat.

Male. Tergite 8 as long as wide, slightly narrowed apicad; distal margin rounded; partially clothed by setae; clothed with microtrichiae. Sternite 8 (Fig. 304) translucent with very small basal transverse sclerite; anterior margin straight with angles truncate; setae concentrate near anterior margin. Sternite 9: distal half gradually narrow to apex and setous. Tergite 9 (Fig. 366): anterior margin strongly notched at middle; punctuate with setae near angles; tergite 10 as long as 9 , punctuate and sparsely setous. Aedeagus (Figs. 451, 452) elongate; basal piece shorter than parameres; parameres fused ventrally; median lobe slightly narrowed apicad with constricted apex; moderately longer than parameres; apex of parameres securiform and rounded.

Material examined. TAIWAN. (Formosa) 1 ex. (MNHN). Kuraru, 1 ex. (MNHN).

Sephilus frontalis Candèze, 1878

(Figs. 45, 46, 92, 243, 305, 367, 453, 454, 490, 514).

Sephilus frontalis Candèze, 1878: 109; Schwarz, 1906: t.3, f. 10; Schenkling, 1925: 83 (cat).

Length: 19.5-24.0 mm. General integument reddish-brown with prothorax and head dark-brown. Pubescence yellow, moderately long and dense. Frons carinate, longer than wide; convex; anterior margin wide and rounded, very prominent, surpassing much nasal; punctuation moderately coarse and dense. Nasal longer than wide. Antennae (Figs. 45, 46) with 11 antennomeres; in male 2 antennomeres longer than pronotum; strongly serrate; scape as long as eye; $2^{\text {nd }}$ antennomere globular, $3^{\text {rd }}$ triangular elongate, with lateral appendix, as long as $4^{\text {th }}$, last narrowed at apex. Labrum (Fig. 92) semielliptical with margin sinuous and long setae. Mandibles wide with one apical and one subapical tooth; penicillus formed by short setae disposed in whole mesal area; dorsal region with carina and moderadely long setae. Maxillae: galea with simple setae; last palpomere securiform. Labium: prementum with setae in front of palpi; postmentum with two long and several short setae. Pronotum (Fig. 243) wider than long, slightly narrowed anteriorly; moderately convex; convexity decreasing basad; grooved longitudinal medially, at base; lateral margins carinate; anterior margin straight; hind angles backwardly directed and carinate; median basal tubercle flat; punctuation moderately 
coarse and very dense. Prosternal channel long. Prosternal spine with narrowed apex. Borders of mesosternal cavity narrow and declivous. Metacoxal plate strongly narrowed laterally; free margin straight. Tibial spurs small; tarsomeres 13 lamellate beneath. Scutellum elongate with posterior margin rounded and lateral margins notched. Elytra moderately convex, narrowed on distal third; with small sutural spine; striae coarsely punctuate and slightly grooved, more strongly grooved basally; interstices equal and flat.

Male. Tergite 8 longer than wide; subtriangular with distal margin rounded; partially clothed by setae; clothed with microtrichiae. Sternite 8 (Fig. 305) elongate, slightly narrowed apicad; partially translucent; anterior margin notched at middle angles rounded; setae concentrate on distal half. Sternite 9: distal half gradually narrow to apex and setous. Tergite 9 (Fig. 367): anterior margin strongly notched at middle; punctuate with setae near angles; tergite 10 longer than 9 , punctuate. Aedeagus (Figs. 453, 454) elongate; basal piece shorter than parameres; parameres fused ventrally; median lobe slightly narrowed apicad, more strongly narrowed subapically and constricted at apex; moderately longer than parameres; apex of parameres securiform preceeded by tooth.

Female. Tergite 8 elongate, subtriangular with narrowed apex; densely setous. Sternite 8 (Fig. 490) elongate, narrowed at apex; clothed with moderately long setae; spiculum gastrale 2.90 times sternite length. Ovipositor with stylus; bursa copulatrix (Fig. 514) with 7 spiny areas; 3 frontal areas partially fused; some disposed star-like.

Material examined. SUMATRA. Palembang, 1 ex. BORNEO. Sarawak, 1 ex. (MNHN). Brunei, 1 ex. (MNHN). Without locality: excoll. Fleutiaux, 1 ex. (MNHN).

\section{Singhalenus Candèze, 1859}

Singhalenus Candèze, 1859: 9, 43; 1891: 56 (cat.); Schwarz, 1906: 60, 72; Fleutiaux, 1928: 104: Schenkling, 1925: 83 (cat.).

Type-species: Singhalenus taprobanicus Candèze, 1859, designated by Hyslop, 1921.

Candèze (1859) erected Singhalenus to two species from "Indies Orientalis". In 1891 he catalogued 3 species to this genus.

Schwarz (1906) included 5 species in the genus.

Schenkling (1925) catalogued 5 species to this genus.

Fleutiaux (1928) characterized the genus, redescribed $S$. candezei Schwarz, 1896 and compared it with other species of this genus.

The genus Singhalenus is formed by 5 species: $S$. candezei Schwarz, 1896, S. gibbus Candèze, 1892, S. horsfieldi Candèze, 1865, S. rubiginosus Candèze, 1859, S. taprobanicus Candèze, 1859. It is recorded from India, Sri Lanka, Vietnam.

The Singhalenus species included in this analysis form a monophyletic group, characterized by homoplasies, 8(2) antennae of male subserrate, 9(2) antennae of female subserrate, 19(1) anterior margin of labrum notched at middle, 28(1) pronotum longer than wide, 37(4) free margin of metacoxal plate with small tooth and 40(0) tibial spurs short. It forms a tricotomy with (Sphenomerus) ((Elius) ((Stenocrepidius simoni)(Heterocrepidius))).

Singhalenus gibbus Candèze, 1892

(Figs. 47, 93, 158, 244, 306, 368, 455, 456, 491, 515).

Singhalenus gibbus Candèze, 1892: 487; Schenkling, 1925: 83 (cat.)

Length: 10.0-25.0 mm. General integument from reddish dark-brown to reddish-brown; legs and antennae clearer. Pubescence whitish, long and moderately dense, longer on pronotum. Frons carinate, strongly convex; longer than wide; anterior margin straight and prominent, surpassing much nasal; punctuation moderately coarse and dense. Nasal wider than long. Antennae (Fig. 47) with 11 antennomeres; in male 2.20 antennomeres longer than pronotum; subserrate; scape shorter than eye; $2^{\text {nd }}$ antennomere globular, $3^{\text {rd }}$ elongate, slightly shorter than $4^{\text {th }}$, last narrowed at apex. Labrum (Fig. 93) semielliptical; anterior margin notched at middle; with long setae. Mandibles (Fig. 158) narrow, with one apical and one subapical tooth; penicillus formed by short setae disposed in whole mesal area; dorsal region with carina and moderately long setae. Maxillae: galea with simple setae; last palpomere securiform. Labium: prementum with setae in front of palpi; postmentum with two long and several moderately long setae. Pronotum (Fig. 244) longer than wide, narrowed anteriorly; strongly convex on anterior half, declivous on basal half; lateral margins carinate; anterior margin prominent; hind angles backwardly directed and carinate; median basal tubercle flat; punctuation coarse and dense. Prosternal channel long. Prosternal spine with narrowed and rounded apex. Borders of mesosternal cavity narrow and declivous. Metacoxal plate strongly narrowed laterally; free margin with tooth. Tibial spurs small; tarsomeres 1-3 lamellate beneath. Scutellum pentagonal elongate. Elytra convex, narrowed on distal third; with tiny sutural spine; striae deeply punctuate; interstices equal and flat.

Male. Tergite 8 longer than wide; slightly narrowed apicad with distal margin rounded; partially clothed by setae; clothed with microtrichiae. Sternite 8 (Fig. 306) transverse, slightly narrowed apicad; almost totally translucent; anterior margin slightly notched at middle; angles prominent and rounded; setae concentrate near anterior margin and at angles. Sternite 9: distal half gradually narrow to apex and setous. Tergite 9 (Fig. 368): anterior margin strongly notched at middle; punctuate with long setae near angles; tergite 10 longer than 9, punctuate and setous. Aedeagus (Figs. 455, 456) elongate; basal piece shorter than parameres; parameres fused ventrally; median lobe gradually narrowed apicad, moderately longer than parameres; apex of parameres securiform.

Female. Tergite 8 elongate, subtriangular with narrowed apex; densely setous. Sternite 8 (Fig. 491) elongate, narrowed at apex; anterior margin rounded; partially clothed with moderately long setae; spiculum gastrale 3.78 times sternite length. Ovipositor with stylus; bursa copulatrix (Fig. 515) with 
7 spiny areas; 3 longitudinal areas partially fused; some disposed star-like.

Material examined. INDIA. Chota Nagapur, 2 exs. (MNHN). Madura, 1 ex. (MNHN).

Singhalenus taprobanicus Candèze, 1859

(Figs. 48, 94, 245, 307, 369, 457, 458, 492, 516).

Singhalenus taprobanicus Candèze, 1859: 44; 1891: 56 (cat.); Schenkling, 1925: 84 (cat.).

Length: 9.0-11.5 mm. General integument reddish darkbrown. Pubescence thin, yellowish-white and moderately long. Frons carinate, strongly convex; longer than wide; anterior margin straight and prominent, surpassing much nasal; punctuation moderately coarse and dense. Nasal wider than long. Antennae (Fig. 48) with 11 antennomeres; subserrate; scape shorter than eye; $2^{\text {nd }}$ antennomere globular, $3^{\text {rd }}$ elongate, slightly shorter than $4^{\text {th }}$, last narrowed at apex. Labrum (Fig. 94) semielliptical; anterior margin notched at middle; with long setae. Mandibles narrow with one apical and one subapical tooth; penicillus formed by short setae disposed in whole mesal area; dorsal region with carina and moderately long setae. Maxillae: galea with simple setae; last palpomere securiform. Labium: prementum with setae in front of palpi; postmentum with two long and several moderately long setae. Pronotum (Fig. 245) longer than wide, slightly narrowed anteriorly; strongly convex on anterior half, declivous on basal half; lateral margins carinate; anterior margin prominent; hind angles backwardly directed and carinate; median basal tubercle flat; punctuation moderately coarse and dense. Prosternal channel long. Prosternal spine with narrowed and rounded apex. Borders of mesosternal cavity narrow and declivous. Metacoxal plate strongly narrowed laterally; free margin with tooth. Tibial spurs small; tarsomeres 1-3 lamellate beneath. Scutellum pentagonal elongate. Elytra convex, narrowed on distal third; with tiny sutural spine; striae deeply punctuate; interstices equal and flat.

Male. Tergite 8 longer than wide; slightly narrowed apicad with distal margin rounded; partially clothed by setae; clothed with microtrichiae. Sternite 8 (Fig. 307) transverse, slightly narrowed apicad; almost totally translucent; anterior margin moderately notched at middle; angles prominent and widely rounded; setae concentrate near anterior margin and at angles. Sternite 9: distal third abruptly narrowed to apex and setous. Tergite 9 (Fig. 369): anterior margin strongly notched at middle; punctuate with moderately long setae near angles; tergite 10 longer than 9, punctuate and setous. Aedeagus (Figs. $457,458)$ elongate; basal piece shorter than parameres; parameres fused ventrally; median lobe gradually narrowed apicad, constricted at apex, moderately longer than parameres; apex of parameres securiform rounded.

Female. Tergite 8 elongate, subtriangular with narrowed apex; densely setous. Sternite 8 (Fig. 492) elongate, narrowed at apex; anterior margin sharpend; partially clothed with short setae, some marginal longer; spiculum gastrale 4.42 times sternite length. Ovipositor with stylus; bursa copulatrix (Fig. 516) with 7 spiny areas; 3 longitudinal areas partially fused; some disposed star-like.

Material examined. INDIA. Mahé, Malabar [coast], 4 exs. (MNHN) Ayur, North Salem, 4 exs (MNHN).

\section{Sphenomerus Candèze, 1859}

Sphenomerus Candèze, 1859: 9, 41; 1891: 56(cat.); Schwarz, 1906: 60 , 70; Schenkling, 1925: 82 (Cat.); Fleutiaux, 1928: 109.

Type-species: Sphenomerus antennalis Candèze, 1859, designated by Hyslop, 1921.

Candèze (1859) erected Sphenomerus to 3 species from Ceylon. According to him, this genus is similar to Heterocrepidius, differing specially by structure of antennae. In 1891 catalogued 5 species to the genus.

Schwarz (1906) included 7 species in the genus.

Schenkling (1925) catalogued 8 species to this genus.

Fleutiaux (1928) described a new species, $S$. duporti and presented an identification key to three species.

Van Zwaluwenburg (1936) described S. melanesiensis and compared it with $S$. bakeri (Fleutiaux).

Kishii (1999) studied the bursa copulatrix of S. takasago e the aedeagus of S. brunneus.

The genus Sphenomerus is formed by 12 species: $S$. angustus Schwarz, 1901(=S. angustatus Schwarz, 1906), S. antennalis Candèze, 1859, S. bakeri (Fleutiaux), S. bonnottei Fleutiaux, 1918, S. brunneus Candèze, 1864, S. canaliculatus Candèze, 1859, S. duporti Fleutiaux, 1928, S. melanesiensis Zwaluwenburg, 1936, S. mouhoti Candèze, 1865, S. rufescens Schwarz, 1901, S. submetallescens Candèze, 1859, S. takasago Kishii, 1991. It is recorded from India, Sri Lanka, Thailandia, Laos, Vietnam, “Tonkin”, Taiwan.

The Sphenomerus species included in this analysis form a monophyletic group, characterized by one synapomorphy, 24(5) galea butterfly wing-like, and by homoplasies, 25(4) setae of galea simple and spatulate and 60(2) apex of sternite 9 of male slightly narrowed. It forms a tricotomy with (Singhalenus) ((Elius) ((Stenocrepidius simoni) (Heterocrepidius))).

Sphenomerus antennalis Candèze, 1859

(Figs. 49, 95, 175, 185, 246, 308, 330, 370, 459, 460).

Sphenomerus antennalis Candèze, 1859: 42; 1891: 56 (cat.); Schekling, 1925: 82 (cat.)

Length: $12.5 \mathrm{~mm}$. General integument dark-brown. Pubescence whitish, moderately long and dense. Frons carinate, longer than wide; concave; anterior margin trapezoidal, prominent, surpassing nasal; punctuation coarse and dense. Nasal wider than long. Antennae (Fig. 49) of male with 11 antennomeres; 2 antennomeres longer than hind angles of pronotum; strongly serrate; antennomeres very wide at apex; scape shorter than eye; $2^{\text {nd }}$ antennomere globular, $3^{\text {rd }}$ 
triangular, slightly shorter than $4^{\text {th }}$; last narrowed at apex. Labrum (Fig. 95) narrow band-like; with long setae. Mandibles narrow, with one apical and one subapical tooth; penicillus formed by short setae disposed in whole mesal area; dorsal region with carina and moderately long setae. Maxillae (Fig. 175): galea very wide, butterfly wing-like, with simple and spatulate setae; last palpomere slightly widened to apex. Labium (Fig. 185): ligula strongly notched medioanteriorly; prementum with setae in front of palpi; postmentum with two long and several moderately long setae. Pronotum (Fig. 246) longer than wide, slightly narrowed anteriorly; moderately convex; lateral margins incompletely carinate; anterior margin slightly prominent at middle; hind angles divergent and not carinate; median basal tubercle flat; punctuation moderately coarse and dense. Prosternal channel long. Prosternal spine with rounded apex. Borders of mesosternal cavity narrow and declivous. Metacoxal plate strongly narrowed laterally; free margin with small lobe. Tibial spurs long; tarsomeres 1-3 lamellate beneath. Scutellum triangular elongate with posterior margin rounded and lateral margins notched. Elytra convex, narrowed on distal third; striae grooved; interstices equal and flat.

Male. Tergite 8 wider than long; slightly narrowed apicad with distal margin rounded; partially clothed by setae; clothed with microtrichiae. Sternite 8 (Fig. 308) transverse with lateral margins rounded; almost totally translucent; anterior margin slightly notched at middle; angles prominent and widely rounded; partially clothed with setae. Sternite 9 (Fig. 330): distal third slightly narrowed to apex and setous. Tergite 9 (Fig. 370): anterior margin strongly notched at middle; microsetose laterally and with long setae near angles; tergite 10 wide, shorter than 9, setous near apex. Aedeagus (Figs. 459,460 ) short and wide; basal piece shorter than parameres; parameres fused ventrally; median lobe gradually narrowed apicad, moderately longer than parameres; apex of parameres securiform sharpened.

Material examined. INDIA. Madura, Shembaganur, 1 ex. (MNHN). Trichinopoli, 1 ex. (MNHN).

Sphenomerus brunneus Candèze, 1865

(Figs. 50, 96, 176, 202, 247, 309, 371, 461, 462).

Sphenomerus brunneus Candèze, 1865: 22; 1891: 56 (cat.); Fleutiaux, 1918: 204; Schekling, 1925: 82 (cat.).

Length: $14 \mathrm{~mm}$. General integument reddish dark-brown; pronotum darker. Pubescence yellowish, moderately long and moderately dense. Frons carinate, longer than wide; convex and flat medioanteriorly; anterior margin prominent, at nasal level; punctuation coarse and dense. Nasal wider than long. Antennae (Fig. 50) of male with 11 antennomeres; not reaching hind angles of pronotum; serrate; scape shorter than eye; $2^{\text {nd }}$ antennomere globular, $3^{\text {rd }}$ elongate, longer than $4^{\text {th }}$; last narrowed at apex. Labrum (Fig. 96) narrow band-like; with long setae. Mandibles narrow, with one apical and one subapical tooth; penicillus formed by short setae disposed in whole mesal area; dorsal region with carina and moderately long setae. Maxillae (Fig. 176): galea wide, butterfly wing-like, with simple and spatulate setae; last palpomere widened to apex. Labium: ligula strongly notched medioanteriorly; prementum with long setae in front of palpi; postmentum with many long setae, 2 of them longer. Pronotum (Fig. 247) wider than long, narrowed anteriorly; moderately convex; lateral margins incompletely carinate; anterior margin slightly prominent at middle; hind angles backwardly directed and carinate; median basal tubercle flat; punctuation moderately coarse and dense. Prosternal channel long. Prosternal spine (Fig. 202) with subapical lobe. Borders of mesosternal cavity narrow and declivous. Metacoxal plate slightly narrowed laterally; free margin with small lobe. Tibial spurs long; tarsomeres 1-3 lamellate beneath. Scutellum slightly longer than wide; subpentagonal with posterior margin rounded. Elytra convex, narrowed on distal third; striae grooved and punctuate; interstices equal and flat.

Male. Tergite 8 wider than long; slightly narrowed apicad with distal margin rounded; partially clothed by setae; clothed with microtrichiae. Sternite 8 (Fig. 309) transverse, narrowed to apex; lateral margins straight; almost totally translucent; anterior margin moderately notched at middle; angles prominent and rounded; setae near middle and laterally. Sternite 9: distal half gradually narrowed to apex and setous. Tergite 9 (Fig. 371): anterior margin strongly notched at middle; punctuate laterally with moderately long setae near angles; tergite 10 longer than 9 , punctuate with some setae near apex. Aedeagus (Figs. 461, 462) short and wide; basal piece shorter than parameres; parameres fused ventrally; median lobe gradually narrowed apicad, with constricted apex; moderately longer than parameres; apex of parameres securiform sharpened.

Material examined. TONKIN, 1 ex. (MNHN).

Spilomorphus Champion, 1894

Spilomorphus Champion, 1894: 296; Schwarz, 1906: 59, 63; Schenkling, 1925: 75 (cat.); Blackwelder, 1944: 297 (cat.).

Type-species: Spilomorphus rubricollis Champion, 1894, by monotypy.

Champion (1894) erected Spilomorphus for S. rubricollis from Panama (Bugaba). He stated about the genus: "...has the meso- and metasternum formed exactly as Spilus; but it differs from it in having the coxal plates undilated opposite the point of insertion of the femora, the legs short, the prosternal sutures parallel behind, the prosternum abruptly declivous behind the coxae, and the antennae with joints from the third broadly triangular".

Schenkling (1925) and Blackwelder (1944) catalogued one species to this genus.

The genus Spilomorphus, monotypical, is recorded from Panama.

No specimen of this genus was examined, but by original description it is possible suppose that this genus belongs to 
Dicrepidiina. According to Champion (1894) this genus presents "tarsi with joints 2 and 3 lamellate beneath" that agrees with the subtribe characterization.

\section{Spilus Candèze, 1859}

Spilus Candèze, 1859: 87; 1891: 60 (cat.); Champion, 1894: 295; Schwarz, 1906: 59, 63: Schenkling, 1925: 75 (cat.); Blackwelder, 1944: 297 (cat.).

Type-species: Spilus rubidus Candèze, 1859, designated by Hyslop, 1921.

Candèze (1859) erected Spilus to 4 new species from South America. In 1891 he catalogued 5 species to this genus.

Champion (1894) described one species from Nicaragua and Panama, S. ciliaticornis.

Schwarz (1906) included 8 species in the genus.

Schenkling (1925) catalogued 8 South American species to this genus besides one from Africa.

Blackwelder (1944) catalogued 8 species to this genus.

The genus Spilus is formed by 9 species: S. africanus Schwarz, 1905, S. atractomorphus Candèze, 1859, S. brevis Candèze, 1881, S. ciliaticornis Champion, 1894, S. crassus Candèze, 1900, S. laevigatus Candèze, 1959, S. nigricans Candèze, 1896, S. nitidus Candèze, 1859, S. rubidus Candèze, 1859. It is recorded from Central America (Nicaragua, Panama), South America (Colombia, Venezuela, Guyana, Brazil) and Africa.

The Spilus species included in this analysis form a monophyletic group, characterized by synapomorphies, 3(4) anterior margin of frons at nasal level at middle and 34(4) prosternal spine with subapical prominent lobe (nose-like), and by homoplasies, 0(2) frons as wide as long, 7(3) nasal very narrow, almost absent at middle and 35(3) borders of mesosternal cavity raised and declivous. It forms a tricotomy with Propsephus beniensis and P. caviforns.

Spilus atractomorphus Candèze, 1859

(Figs. 51, 97, 203, 248, 271, 493, 517-519).

Spilus atractomorphus Candèze, 1859: 88; 1891: 60 (cat.); Schenkling, 1925: 75 (cat.); Blackwelder, 1944: 297 (cat.).

Length: 11-14 mm. General integument from yellowish reddish-brown to reddish-brown. Pubescence yellow long and dense. Frons carinate, as long as wide; slightly concave medioanteriorly; anterior margin rounded, depressed at middle, not prominent, at nasal level; punctuation moderately coarse and dense. Nasal narrow, wider than long. Antennae (Fig. 51) with 11 antennomeres; in male, 2 antennomeres longer than hind angles of pronotum; serrate; scape shorter than eye; $2^{\text {nd }}$ antennomere globular, $3^{\text {rd }}$ triangular, shorter than $4^{\text {th }}$, last narrowed at apex. Labrum (Fig. 97) semicircular; with long setae. Mandibles wide, with one apical and one subapical tooth; penicillus formed by short setae disposed in whole mesal area; molar area present; dorsal region with carina and moderately long setae. Maxillae: galea with simple setae; last palpomere securiform. Labium: prementum with long setae in front of palpi; postmentum with two long and several moderately short setae. Pronotum (Fig. 248) wider than long, gradually narrowed anteriad; moderately convex on anterior $2 / 3$ and declivous on basal third; grooved longitudinal medially on basal third; lateral margins carinate; anterior margin straight; hind angles long, backwards and carinate; median basal tubercle flat; punctuation moderately coarse and dense, smaller and sparser on basal third. Prosternal channel long. Prosternal spine with subapical tubercle nose-like. Borders of mesosternal cavity (Fig. 203) raised and declivous. Metacoxal plate (Fig. 271) narrowed laterally; free margin with well developed tooth. Tibial spurs long; tarsomeres 1-3 lamellate beneath. Scutellum pentagonal elongate with posterior margin rounded. Elytra convex, slightly narrowed on distal third; striae coarsely punctuate; interstices equal and flat.

Female. Tergite 8 elongate, slightly narrowed apicad; distal margin rounded; densely setous. Sternite 8 (Fig. 493) elongate, slightly narrowed apicad; anterior margin rounded; clothed with short setae, some marginal longer; spiculum gastrale 3.62 times sternite length. Ovipositor with stylus; bursa copulatrix (Figs. 517-519) with 7 spiny areas; some disposed star-like.

Material examined. Cayenne, ex-Collection Jekel, 1 ex. (MNHN). Without locality, 1 ex. (MNHN).

Spilus nitidus Candèze, 1859

(Figs. 52, 98, 151, 152, 249, 310, 372, 463, 464).

Spilus nitidus Candèze, 1859: 88; 1891: 60 (cat.); Schenkling, 1925: 76 (cat.); Blackwelder, 1944: 297 (cat.)

Length: 13-15 mm. General integument dark reddishbrown. Pubescence whitish, long and dense. Frons carinate, as long as wide; slightly concave medioanteriorly; anterior margin rounded, depressed at middle, not prominent, at nasal level; punctuation moderately coarse and dense. Nasal narrow, wider than long. Antennae (Fig. 52) with 11 antennomeres; in male not reaching hind angles of pronotum; serrate; scape shorter than eye; $2^{\text {nd }}$ antennomere globular, $3^{\text {rd }}$ triangular, shorter than $4^{\text {th }}$, last narrowed at apex. Labrum (Fig. 98) narrow band-like; with long setae. Mandibles (Figs. 151, 152) wide, with one apical and one subapical tooth; penicillus formed by short setae disposed in whole mesal area; molar area present; dorsal region with carina and moderadely long setae. Maxillae: galea with simple setae; last palpomere securiform. Labium: prementum with long setae in front of palpi; postmentum with two long and several moderately short setae. Pronotum (Fig. 249) wider than long, gradually narrowed anteriad; moderately convex on anterior $2 / 3$ and declivous on basal third; grooved longitudinal medially on basal third; lateral margins carinate; anterior margin straight; hind angles backwardly directed and carinate; median basal tubercle indistinct; punctuation moderately coarse and dense, smaller and sparser on basal third. Prosternal channel long. Prosternal spine with subapical tubercle nose-like. Borders of mesosternal cavity raised and declivous. Metacoxal plate narrowed laterally; 
free margin with well developed tooth. Tibial spurs long; tarsomeres 1-3 lamellate beneath. Scutellum subtriangular elongate with posterior margin rounded. Elytra convex, slightly narrowed on distal third; striae coarsely punctuate; interstices equal and flat.

Male. Tergite 8 slightly wider than long; slightly narrowed apicad with distal margin rounded; partially clothed by setae; clothed with microtrichiae. Sternite 8 (Fig. 310) transverse, slightly narrowed apicad; almost totally translucent; anterior margin widely rounded; setae concentrate near anterior margin. Sternite 9: distal half gradually narrowed to apex and setous. Tergite 9 (Fig. 372): anterior margin strongly notched at middle; punctuate laterally and with moderately long setae near angles; tergite 10 slightly longer than 9 and setous. Aedeagus (Figs. 463, 464) elongate; basal piece shorter than parameres; parameres fused ventrally; median lobe slightly narrowed apicad; apex of parameres securiform excavate.

Material examined. PERU. 2 exs. (MNHN). Madre de Dios , 5 exs (MNHN).

\section{Stenocrepidius Schwarz, 1902}

Stenopus Schwarz, 1900: 307 (preoccupied).

Stenocrepidius Schwarz, 1902: 126; 1906: 60, 65; Schenkling, 1925: 77 (cat.); Blackwelder, 1944: 297 (cat.).

Type-species: Stenopus angustus Schwarz, 1900, designated by Hyslop, 1921.

Schwarz (1900) erected Stenopus to three species from "Caucathal": S. angustus, S. elongatus and S. rubripennis.

Schwarz (1902) treating of "Neue Elateridae aus Australien" included at the end of the article: "Aenderung des Gattungsnames Stenopus Schw. in Stenocrepidius Schw. Für die von mir in der Deutsch. Ent. Zeitschr. 1900 pag. 307 aufgestellte Gattung ändere ich den namen Stenopus da dieser bereits anderweiting vergeben est, in Stenocrepidius um". In 1906 included 5 species in Stenocrepidius.

Schenkling (1925) and Blackwelder (1944) catalogued 5 species to this genus.

The genus Stenocrepidius is formed by 5 species: $S$. angustus (Schwarz, 1900), S. elongatus (Schwarz, 1900), S. estebanus (Fleutiaux, 1891), S. rubripennis (Schwarz, 1900)

5. S. simoni Fleutiaux, 1891. It is recorded from South America (Colombia, Venezuela).

Stenocrepidius simoni is characterized by one synapomorphy, 65(4) subapical region of parameres narrowed and truncate, and by homoplasies, 0(2) frons as wide as long, $3(0)$ anterior margin of frons at nasal level, 29(1) hind angles of pronotum divergent, 42(1) lamella of protarsomere 1 absent, 43(1) lamella of mesotarsomere 1 absent and 61(0) aedeagus short and wide. It is the sister-group of Heterocrepidius.

Stenocrepidius simoni (Fleutiaux, 1891)

(Figs. 99, 250, 272, 311, 373, 465, 466).

Heterocrepidius simoni Fleutiaux, 1891:276.

Stenopus simoni; Schwarz, 1900: 308.
Stenocrepidius simoni; Schenkling, 1925: 78 (cat.): Blackwelder, 1944:297 (cat.).

Length: 8.5-9.5 mm. General integument brown, slightly reddish-brown; legs clearer. Pubescence whitish, moderately long and dense. Frons carinate, as long as wide; slightly concave medioanteriorly; anterior margin wide and slightly rounded, surpassing nasal; punctuation moderately coarse and dense. Nasal narrow, wider than long. Antennae (broken): scape shorter than eye; $2^{\text {nd }}$ antennomere globular, $3^{\text {rd }}$ elongate and very short, shorter than $4^{\text {th }}$. Labrum (Fig.99) narrow bandlike; with long setae. Mandibles narrow, with one apical and one subapical tooth; penicillus formed by short setae disposed in almost whole mesal area; dorsal region with carina and moderately long setae. Maxillae: galea with simple setae; last palpomere elliptical. Labium: prementum with long setae in front of palpi; postmentum with two long and several moderately long setae. Pronotum (Fig. 250) wider than long; moderately convex; lateral margins incompletely carinate; anterior margin prominent at middle; hind angles divergent and carinate; median basal tubercle indistinct; punctuation moderately coarse and dense. Prosternal channel absent. Prosternal spine with bilobed apex. Borders of mesosternal cavity narrow and declivous. Metacoxal plate (Fig. 272) strongly narrowed laterally; free margin with small lobe. Tibial spurs long; tarsomeres 2-3 lamellate beneath. Scutellum subpentagonal elongate with posterior margin rounded. Elytra convex; slightly narrowed on distal 2/3; striae grooved; interstices equal and flat.

Male. Tergite 8 slightly wider than long; slightly narrowed apicad with distal margin rounded; partially clothed by setae; clothed with microtrichiae. Sternite 8 (Fig. 311) tranverse: translucent with transversal basal sclerite; anterior margin straight; anterior angles rounded; setae concentrate near anterior margin. Sternite 9: distal half gradually narrowed to apex and setous. Tergite 9 (Fig. 373): anterior margin strongly notched at middle; punctuate laterally and with setae near angles; tergite 10 slightly longer than 9 , punctuate and setous. Aedeagus (Figs. 465, 466) short and wide; basal piece shorter than parameres; parameres fused ventrally; median lobe constricted near base and at apex, slightly narrowed apicad; apex of parameres slightly narrowed and straight.

Material examined. VENEZUELA. Caracas, 1 ex. (MNHN).

Trielasmus Blanchard, 1843

Trielasmus Blanchard, 1843: 131; Candèze, 1859: 147; 1891: 63 (cat.); Schenkling, 1925: 85 (cat.); Blackwelder, 1944: 299 (cat.).

Type-species: Trielasmus varians Blanchard, 1843, designated by monotypy.

Blanchard (1843) erected Trielasmus to T. varians based on one specimen collected "sur the arbustes près de SantaAna, dans la provice de Chiquitos".

Schenkling (1925) and Blackwelder (1944) catalogued one species to this genus. 
The genus Trielasmus, monotypical, is recorded from South America (Bolivia, Argentina).

Trielasmus varians is characterized by homoplasies, 1(2) frontal carina incomplete and 7(3) nasal very narrow, almost absent at middle. It is the sister-group of ((Paraloboderus glaber)((Loboederus appendiculatus)(Proloboderus crassipes))).

Trielasmus varians Blanchard, 1843

(Figs. 53, 100, 153, 154, 159, 251, 494).

Trielasmus varians Blanchard, 1843: 131; Candèze, 1859: 147; 1891: 63 (cat.); Schwarz, 1906: 317; Schenkling, 1925: 86 (cat.).

Length: $12.5 \mathrm{~mm}$. General integument dark-brown. Pubescence whitish, long and moderately dense. Frons incompletely carinate, wider than long; anterior margin slightly rounded, flat at middle, not prominent, at nasal level; punctuation moderately coarse and dense. Nasal very short, wider than long. Antennae (Fig. 53) with 11 antennomeres; in female, serrate; scape shorter than eye; $2^{\text {nd }}$ antennomere globular, $3^{\text {rd }}$ triangular, shorter than $4^{\text {th }}$. Labrum (Fig. 100) subrectangular, band-like; with long setae. Epipharynx (Fig. 159): membranous with two striate areas near base; two median bands of microtrichiae convergent at base; sensorial points and 2 setae near middle. Mandibles (Figs. 153,154) very narrow, with sharpened apex and subapical tooth; penicillus formed by short setae disposed in whole mesal area; molar area present; dorsal region with carina and moderately long setae. Maxillae: galea with simple setae; last palpomere slightly widened to apex. Labium: prementum with long setae in front of palpi; postmentum with two long and several short setae. Pronotum (Fig. 251) wider than long; moderately convex; lateral margins carinate; anterior margin slightly prominent at middle; hind angles backwardly directed and carinate; median basal tubercle indistinct; punctuation moderately small and moderately dense, finer on basal third. Prosternal channel absent. Prosternal spine with subapical small lobe and apex narrowed. Borders of mesosternal cavity narrowed and declivous. Metacoxal plate slightly narrowed laterally; free margin straight. Tibial spurs long; tarsomeres 1-3 lamellate beneath. Scutellum subtriangular elongate. Elytra convex, slightly narrowed on distal $2 / 3$; striae grooved; interstices equal and flat.

Female. Tergite 8 triangular elongate; densely setous. Sternite 8 (Fig. 494) elongate, elliptical; short setae longitudinal medialy, some marginal longer; spiculum gastrale 4.15 times sternite length. Ovipositor with stylus; bursa copulatrix without spines or sclerotized pieces.

Material examined. BRAZIL. Mato Grosso, 1 ex. (MNHN). ECUADOR. 1 ex. (MNHN). ARGENTINA. Santiago del Estero; 55 $\mathrm{Km}$ au N. D'Icano, 2 exs (MNHN). BOLIVIA. Santa Cruz de la Sierra: Chiquitos, 1 ex. (MNHN).

\section{GENUS REMOVED FROMTHE SUBTRIBE}

\author{
Ovipalpus Solier, 1851
}

Ovipalpus Solier, 1851: 9; Lacordaire, 1857: 220; Candèze, 1863: 513; 1891: 59 (cat.); Schwarz, 1906: 60, 71; Schenkling, 1925: 83 (cat.); Blackwelder, 1944: 298 (cat.).

Type-species: Ovipalpus pubescens Solier, 1851, designated by monotypy.

Solier (1851) erected Ovipalpus to $O$. pubescens from Concepcion (Chile). Lacordaire (1857) presented a diagnosis to genus.

Candèze (1863) in the "Additions et Corrections" stated about Ovipalpus: “ ... établi sur une espèce (pubescens) qui me paraît devoir rentrer dans le genre Anoplischius". In 1891, he characterized the genus only with the type-species.

Schenkling (1925) and Blackwelder (1944) catalogued two species to this genus.

Golbach (1953) described a new species, O. schajovskoii and presented a key to the 3 species and one subspecies of the genus. He also presented a discussion among the known species.

The genus Ovipalpus is formed by three species: O. piceus Fleutiaux, 1910, O. pubescens Solier, 1851 (= Cylindroderus chilensis Candèze, 1878; var. ruficeps Fleutiaux, 1910), O. schajovskoii Golbach, 1953. It is recorded from Chile.

Ovipalpus pubescens is characterized by synapomorphies, 3(3) anterior margin of frons fused to nasal, 24(4) galea narrow (tongue-like) and 36(2) lateral margin of metacoxal plate widened laterally and by homoplasies, 2(3) anterior margin of frons straight, 4(4) median anterior region of frons downwards, 18(2) labrum subtrapezoidal, 20(1) mandibles narrow, 27(2) last palpomere elliptical and 58(2) distal margin of tergite 9 of male moderately notched at middle. It is the sister-group of Ctenicera silvatica. It was exclude from Dicrepidiina and also from Ampedini. It is supposed that it belongs to Prosternini (Prosterninae).

Ovipalpus pubescens Solier, 1851

(Figs. 31, 82, 139, 140, 169, 180, 232, 266, 298, 360, 434, 435).

Ovipalpus pubescens Solier, 1851: 10; Schenkling, 1925: 83 (cat.); Blackwelder, 1944: 298 (cat.).

Cylindroderus chilensis Candèze, 1878: 199; Fleutiaux, 1907: 227.

Length: 12-14 mm. General integument black with prothorax yellow. Pubescence grayish, moderately long and dense. Frons not carinate, wider than long; frontally, almost vertical; punctuation coarse and dense. Nasal absent. Antennae (Fig. 31) with 11 antennomeres; in male 2 antennomeres longer than hind angles of pronotum; serrate; scape much shorter than eye; $2^{\text {nd }}$ antennomere globular, $3^{\text {rd }}$ elongate, very short, shorter than $4^{\text {th }}$, last narrowed at apex. Labrum (Fig. 82) subtrapezoidal with rounded angles and setous. Mandibles (Figs. 139, 140) elongate with 3 teeth; penicillus elongate, formed by short setae disposed in mesal area; molar area absent; dorsal region 
with carina and moderately long setae. Maxillae (Fig. 169): galea and lacinia narrow, tongue-like, clothed with simple setae; last palpomere oval. Labium (Fig. 180): prementum with very long setae in front of palpi; anterior margin of ligula notched at middle; postmentum with several moderately long setae. Pronotum (Fig. 232) wider than long; convex; anterior margin straight; lateral margins almost straight and carinate only basally; hind angles strongly divergent and carinate; median basal tubercle transverse and flat; punctuation moderately coarse and dense. Prosternal channel absent. Prosternal spine with subapical lobe. Borders of mesosternal cavity narrow and declivous. Metacoxal plate (Fig. 266) slightly widened laterally; free margin straight. Tibial spurs long; tarsomeres not lamellate beneath. Scutellum subpentagonal elongate. Elytra convex, slightly narrowed on distal half; striae grooved and punctuate; interstices equal and flat.

Male. Tergite 8 slightly longer than wide,with anterior margin rounded; punctuate and marginate by fringe of setae; clothed with microtrichiae. Sternite 8 (Fig.298) transverse, slightly narrowed to apex; anterior margin notched at middle; anterior angles rounded; partially translucent; setae moderately long disposed in lateral bands. Sternite 9: distal half gradually narrowed to apex; distal third setous. Tergite 9 (Fig. 360) : anterior margin strongly notched at middle; sparsely punctuate; tergite 10 shorter than 9, setous at apex. Aedeagus (Figs. 434, 435) elongate, wide; basal piece very short, located above parameres base; parameres separate ventrally; median lobe slightly narrowed apicad, with rounded apex; moderately longer than parameres; parameres with dilated apex, boothlike.

Material examined. CHILE. 1 ex. (MNHN). Provincia de Curicó: Curicó, Cubiilo, 1 ex. (MZSP). Provincia de Talca: (Taka), Vilches, 2 exs (MZSP).

\section{OUTGROUPS}

Chalcolepidius zonatus Eschscholtz, 1829

(Figs. 14, 280, 340, 394, 395, 473, 503).

Chalcolepidius zonatus Eschscholtz, 1829:32; Casari, 2002: 347.

Length: 22-43 mm. Frons not carinate; nasal absent. Antennae (Fig. 14) serrate in both sexes, in male not reaching hind angles of pronotum; scape shorter than eye; $2^{\text {nd }}$ antennomere globular, $3^{\text {rd }}$ triangular elongate, shorter than $4^{\text {th }}$. Labrum transverse, slightly narrowed apicad with long setae. Mandibles robust with one apical tooth; penicillus like narrow band; molar area absent; dorsal region with carina and long setae. Maxillae: galea brush-like with simple setae; last palpomere securiform. Pronotum longer than wide, wider at hind angles, slightly narrowed anteriad from hind angles apex; anterior margin prominent and sinuous at middle; hind angles wide, slightly divergent, with truncate apex, raised laterally forming edge continues with that of lateral margin; median basal tubercle triangular-elongate and very weak or indistinct; convexity moderate; densely micropunctate with sparse umbilicate punctures more concentrate lateroanteriorly. Prostenal channel well developed. Notosternal sutures strongly sinuous. Prosternal spine flattened laterally with rounded apex. Borders of mesosternal cavity wide and horizontal on basal $3 / 4$ and vertical on distal $1 / 4$. Meso-metasternal suture weak.Metacoxal plate moderately narrowed laterally; free margin straight.Tibial spurs absent. Anterior and median tibiae and last tarsal segment of all legs of male bearing fringe of long cilia. Scutellum strongly folded with horizontal basal area triangular, notched anterior- and posteriorly, grooved longitudinal medially on anterior half.

Male. Sternite 8 (Fig. 280) transverse, narrowed apicad, subtrapezoidal, basal margin trilobed (median lobe wider) translucent at median region and two small spots each side. Tergite 9 (Fig. 340) densely punctuate, anterior margin rounded. Aedeagus (Figs. 394, 395): median lobe slightly narrowed near middle, constricted at apex; bearing lateral teeth; subapical region of parameres cleft.

Female. Sternite 8 (Fig. 473) with anterior margin moderately wide and deeply notched at middle; spiculum gastrale 1.40 times sternite length. Ovipositor (Fig. 503) without stylus; bursa copulatrix with three spiny areas; openings of colleterial glands with sclerotized rings.

Material examined. BRAZIL. Pará: Santarém, 1 ex. (MZSP). Goiás: 2 exs (MZSP); Muquém, 1 ex. (MZSP). Mato Grosso: Barra do Tapirapé, 1 ex. (MZSP); Jacaré, Xingu 1ex. (MZSP); Roncador, 1 ex. (MZSP). Minas Gerais: Lavras, 3 exs (MZSP); Mariana, 2 exs (MZSP); Rio Matipó, 1 ex. (MZSP); Santa Bárbara, Serra do Caraça, 1 ex. (MZSP); São José das Ilhas, Faz. Palmeiras, 2 exs (MZSP); Viçosa, 10 exs (MZSP). Rio de Janeiro: 2 exs (MZSP); Angra dos Reis, 2 exs (MZSP); Bocaina, 1 ex. (MZSP); 6 exs (MZSP); Mendes, 1 ex. (MZSP); Petrópolis, 1 ex. (MZSP); Serra dos Órgãos, 1 ex. (MZSP); Teresópolis, 1 ex. (MZSP). Espírito Santo: 1 ex. (MZSP); Santa Teresa, 17 exs (MZSP). São Paulo: Anhembi, 1 ex. (MZSP); Barueri, 1 ex. (MZSP); Botucatu, 2 exs (MZSP); Campinas, 1 ex. (MZSP); Guarujá, 1 ex. (MZSP), Iporanga, 1 ex. (MZSP); Ilha de Búzios, 3 exs (MZSP); Ilha de São Sebastião, 3 exs (MZSP); Ipeúna, 1 ex. (MZSP); Itararé, 3 exs (MZSP); Itatiba, 1 ex. (MZSP); Itu, Faz. Pau d'Alho, 8 exs (MZSP); Jundiaí, 2 exs (MZSP); Manoel da Nóbrega, 1 ex. (MZSP); Pai Mathias, 1 ex. (MZSP); Peruíbe, Estrada do Grajau, 1 ex. (MZSP); Piracicaba, 2 exs (MZSP); Pirassununga, 1 ex. (MZSP); Rio Mombuca , 3 exs (MZSP); Santos, 2 exs (MZSP), Praia Grande, 1 ex. (MZSP), Cidade da Criança, 2 exs (MZSP), Praia do Itaguaré, 1 ex. (MZSP); São Manuel, 1 ex. (MZSP); São Paulo, 5 exs (MZSP), Booklin, 1 ex. (MZSP), Horto Florestal, 3 exs (MZSP), Ipiranga, 4 exs (MZSP), Ubatuba, 1 ex. (MZSP). Paraná: Curitiba, 4 exs (MZSP); Jaguariaiva, 1 ex. (MZSP); Matinhos 1 ex. (MZSP); Paranaguá, 1 ex. (MZSP); Ponta Grossa, 14 exs (MZSP); Porto Cabral, 1 ex., (MZSP). Santa Catarina: 1 ex. (MZSP); Joinville, 12 exs (MZSP), Rio Bracinho, 1 ex. (MZSP); Rio Natal, 4 exs (MZSP); Rio Vermelho, 43 exs (MZSP); São Bento do Sul, 12 exs (MZSP); Timbó, ex-coll. Dirings, 33 exs, (MZSP). Rio Grande do Sul: Vila Oliva, 1 ex. (MZSP).

Ctenicera silvatica (Van Dyke, 1932)

(Figs. 15, 67, 120, 216, 282, 343, 400, 401, 476).

Ludius silvaticus Van Dyke, 1932: 409.

Ctenicera silvatica; Blackwelder \& Arnett, 1974: 48.

Length: 14-22 mm. General integument dark-brown with antennae black. Pubescence long, dense, whith metallic shine. Frons not carinate, wider than long, flat; anterior margin at nasal level; punctuation moderately coarse and dense. Nasal 
wider than long. Antennae (Fig. 15) with 11 antennomeres; in male 2 antennomeres longer than hind angles of pronotum; slightly serrate in both sexes; scape shorter than eye; $2^{\text {nd }}$ antennomere globular, $3^{\text {rd }}$ triangular elongate, longer than $4^{\text {th }}$, last narrowed at apex. Labrum (Fig. 67) semielliptical, with long setae. Mandibles (Fig. 120) robust, with apex wide with one subapical tooth and one lobe between teeth; penicillus narrow, formed by short setae disposed in whole mesal area; dorsal region with carina and moderadely long setae. Maxillae: galea with simple setae; last palpomere securiform. Labium: postmentum with two long setae and several moderately short. Pronotum (Fig. 216) longer than wide, slightly narrowed anteriad; moderately convex; lateral margins carinate; anterior margin almost straight; hind angles divergent and carinate; median basal tubercle indistinct; punctuation moderately coarse and dense. Prosternal channel absent. Prosternal spine with subapical lobe. Borders of mesosternal cavity declivous. Metacoxal plate strongly narrowed laterally; free margin with small lobe, almost straight. Tibial spurs long; tarsomeres not lamellate beneath. Scutellum elongate with posterior margin rounded. Elytra convex, slightly narrowed to apex; striae punctuate and grooved; interstices punctuate, equal and flat.

Male. Tergite 8 wider than long with distal margin rounded; setous; clothed with microtrichiae. Sternite 8 (Fig. 282) transverse, slightly narrowed on anterior angles; anterior margin straight with angles moderately prominent; translucent with lateral and basal irregular bands yellowish; setae concentrate near angles. Sternite 9: distal half gradually narrow to apex and setous. Tergite 9 (Fig. 343) strongly notched at middle; V-shaped; with setae concentrate laterally on distal half; tergite 10 shorter than 9 with apex notched. Aedeagus (Figs. 400, 401) elongate; basal piece short, transverse, located on parameres base; parameres separate ventrally; median lobe narrow, slightly narrowed apicad, with apex rounded; parameres without setae and apex foot-like.

Female. Tergite 8 elongate, triangular; translucent medianbasally; setous laterally and at apex. Sternite 8 (Fig. 476) setous with apex triangular; spiculum gastrale 3.80 times sternite length. Ovipositor with styli; bursa copulatrix without sclerotized pieces or spines.

Material examined. UNITED STATES OF AMERICA. California: Mt Lassen, 4 exs (MZSP); Tehama County: $12 \mathrm{mi} \mathrm{W}$ Minéral, 2 exs (MZSP); 6 mi E Minéral, 2 exs (MZSP).

Melanotus spernendus Candèze, 1873

(Figs. 29, 80, 135, 136, 167, 296, 358, 430, 431, 483, 508).

Melanotus spernendus Candèze, 1873: 21; 1891: 142 (cat.); Lewis, 1894:192; Schenkling, 1925: 281 (cat.).

Length: 15.5-18.5 mm. General integument dark-brown; antennae and legs clearer. Pubescence yellow, dense and moderately long. Frons carinate, wider than long; convex; anterior margin wider and rounded, surpassing nasal in narrow band; punctuation coarse and dense. Nasal short, wider than long. Antennae (Fig.29) with 11 antennomeres; in male one antennomere longer than hind angles of pronotum; slightly serrate in both sexes; scape shorter than eye; $2^{\text {nd }}$ antennomere globular, $3^{\text {rd }}$ cylindrical, shorter than $4^{\text {th }}$, last narrowed at apex. Labrum (Fig. 80) semicircular, with long setae. Mandibles (Figs. $135,136)$ narrow, with subapical tooth; penicillus formed by short setae disposed in whole mesal area; dorsal region with carina and moderadely long setae. Maxillae (Fig. 167): galea with long bristle setae; last palpomere securiform. Labium: prementum with setae in front of palpi; postmentum with two long setae and several moderately short. Pronotum wider than long, narrowed anteriad; moderately convex; convexity decreasing basad; lateral margins carinate; anterior margin Ushaped; hind angles long, backwardly directed and strongly carinate; median basal tubercle flat; punctuation coarse and dense, smaller and denser on median basal third. Prosternal channel present. Prosternal spine with subapical lobe. Borders of mesosternal cavity declivous. Metacoxal plate strongly narrowed laterally; free margin straight. Tibial spurs long; tarsomeres not lamellate beneath; claws pectinate. Scutellum pentagonal with posterior margin rounded. Elytra convex, slightly narrowed to apex; striae punctuate and grooved; interstices equal and flat.

Male. Tergite 8 elongate, slightly narrowed apicad, with distal margin rounded; setous; clothed with microtrichiae. Sternite 8 (Fig. 296) transverse, narrowed on distal half; anterior margin strongly notched at middle; fore angles rounded; translucent with lateral bands yellowish and sclerite transversal basal; setae concentrate on distal half. Sternite 9: distal half gradually narrow to apex and setous. Tergite 9 (Fig. 358) moderately notched at middle; punctuate with setae concentrate near angles; tergite 10 longer than 9 and setous. Aedeagus (Figs. 430, 431) elongate; basal piece shorter than parameres, parameres separate ventrally; median lobe narrowed apicad with apex constricted and rounded; apex of parameres securiform.

Female. Tergite 8 elongate, slightly narrowed apicad with anterior margin rounded; clothed with setae. Sternite 8 (Fig. 483) slightly narrowed apicad, densely clothed with setae; spiculum gastrale 3.82 times longer than sternite. Ovipositor with styli; bursa copulatrix (Fig. 508) very elongate with one spiny area.

Material examined. JAPAN. Nagai-cho, Osaka, 10 exs (MZSP).

Ampedus sanguineus (Linnaeus, 1758)

(Figs. 6, 57, 105, 106, 160, 189, 207, 252, 275, 334, 382, 383).

Elater sanguineus Linnaeus, 1758: 405; Candèze, 1859: 442; Schenkling, 1925: 153(cat.).

Ampedus sanguineus; Dejean, 1833: 104; LeConte, 1884: 32.

Length: 11.5-15.5 mm. General integument dark-brown to black with elytra orange. Pubescence black, moderately long, denser on pronotum. Frons carinate, wider than long, convex; anterior margin rounded and prominent at middle, surpassing nasal; punctuation moderately coarse and dense. Nasal very narrow, wider than long. Antennae (Fig.6) with 11 
antennomeres; in male not reaching hind angles of pronotum; slightly serrate in both sexes; scape shorter than eye; $2^{\text {nd }}$ antennomere globular, $3^{\text {rd }}$ elongate, shorter than $4^{\text {th }}$, last with narrowed at apex. Labrum (Fig.57) semielliptical, notched at middle with long setae. Mandibles (Figs. 105, 106) robust, with one apical and one subapical tooth; penicillus well developed, formed by short setae disposed in wide band in whole mesal area; molar area absent; dorsal region with carina and moderately long setae. Maxillae (Fig. 160): galea with spatulate setae; last palpomere securiform. Labium (Fig. 189): prementum with setae in front of palpi; postmentum with two long setae and several short [represented by punctures]. Pronotum (Fig. 207) wider than long, narrowed anteriorly; moderately convex; lateral margins carinate; anterior margin slightly prominent at middle; hind angles backwardly directed and carinate; median basal tubercle flat; punctuation moderately coarse and dense, finer and sparser on basal third. Prosternal channel short. Prosternal spine with narrowed apex and subapical lobe. Borders of mesosternal cavity narrow and declivous. Metacoxal plate (Fig. 252) strongly narrowed laterally; free margin with well developed lobe. Tibial spurs very long; tarsomeres not lamellate beneath. Scutellum elongate with posterior margin rounded. Elytra moderately convex, slightly narrowed to apex; striae coarsely punctuate, grooved near base; interstices equal and flat.

Male. Tergite 8 wider than long, slightly narrowed apicad, with distal margin rounded; punctuate on anterior half and marginate by setae; clothed with microtrichiae. Sternite 8 (Fig. 275) transverse, slightly narrowed apicad; anterior margin straight with rounded angles; translucent with lateral and basal irregular bands yellowish; setae concentrate near angles and microsetae at middle, near anterior margin. Sternite 9: distal half gradually narrow to apex and setous. Tergite 9 (Fig. 334) strongly notched at middle; punctuate with setae concentrate near angles; tergite 10 longer than 9 with setae on distal 2/3. Aedeagus (Figs. 382, 383) short and wide; basal piece short, located on parameres base; parameres separate ventrally; median lobe narrowed near base and at apex; apex of parameres triangular.

Material examined. SLOVAKIA. Harmanec, 1 ex. (MZSP). Mor., Tkvice, 1 ex. (MZSP). Without locality, 1 ex. (MZSP)

Anchastus digittatus LeConte, 1853

(Figs. 7, 58, 107, 108, 208, 253, 469, 495).

Anchastus digittatus LeConte, 1853: 459; Lacordaire, 1857: 176; Candèze, 1891: 106 (cat.); Schenkling, 1925: 187 (cat.); Blackwelder, 1974: 50 (cat.).

Length: $11 \mathrm{~mm}$. General integument yellowish-brown. Pubescence yellow, moderately long and dense. Frons carinate, wider than long; convex; anterior margin strongly rounded, prominent at middle, surpassing nasal in very narrow stripe; punctuation moderately coarse and very dense. Nasal wider than long. Antennae (Fig. 7) with 11 antennomeres; in female, not reaching hind angles of pronotum; subserrate in both sexes; scape shorter than eye; $2^{\text {nd }}$ antennomere globular, $3^{\text {rd }}$ globular, longer than $2^{\text {nd }}$ and shorter than $4^{\text {th }}$, last with apex narrowed. Labrum (Fig. 58) semicircular, narrowed at base, with long setae. Mandibles (Figs. 107, 108) robust, with one apical and one subapical tooth; penicillus formed by short setae disposed in wide band in whole mesal area; with lobe at base; molar area well developed; dorsal region with carina and moderadely long setae. Maxillae: galea with spatulate setae; last palpomere securiform. Labium: prementum with long setae in front of palpi; postmentum with two long setae, with several moderately long setae. Pronotum (Fig. 208) slightly wider than long, strongly narrowed frontally; moderately convex; lateral margins carinate; anterior margin slightly notched; hind angles backwardly directed and not carinate; median basal tubercle flat; punctuation moderately small and dense. Prosternal channel short. Prosternal spine with sharpened apex and subapical small tooth. Borders of mesosternal cavity narrowed and declivous. Metacoxal plate (Fig. 253) strongly narrowed laterally; free margin with well developed lobe. Tibial spurs very long; tarsomere 3 lamellate beneath. Scutellum subtriangular elongate with posterior margin rounded. Elytra moderately convex, narrowed on distal third; striae coarsely punctuate; interstices equal and flat.

Female. Tergite 8 slightly wider than long, narrowed to apex; distal margin rounded; median basal area translucent; densely setous. Sternite 8 (Fig. 469) triangular, clothed with setae; spiculum gastrale 5.75 times sternite length. Ovipositor with stylus; bursa copulatrix (Fig. 495) narrow, spiraled at apex, with spines innerly.

Material examined. UNITED STATES OF AMERICA. Georgia: Fulton Co. Atlanta, 1 ex. (MZSP)

Physorhinus xanthocephalus Germar 1840

(Figs. 36, 85, 143, 144, 172, 182, 200, 237, 267, 299, 361, $441,442,485,511)$.

Physorhinus xanthocephalus Germar, 1840: 245; Candèze, 1859: 392; 1891: 103 (cat.); Schenkling, 1925:182 (cat.); Blackwelder, 1944: 301 (cat.).

Length: $10-12 \mathrm{~mm}$. General integument brown with frons and lateral irregular band of elytra yellow; anterior margin of frons brown; legs clearer. Pubescence yellow, moderately long and dense. Frons carinate, wider than long; convex; anterior margin wide and rounded, prominent, surpassing nasal; punctuation moderately coarse and moderately dense. Nasal wider than long. Antennae (Fig. 36) with 11 antennomeres; in male 2.2 antennomere longer than hind angles of pronotum; subserrate in both sexes; scape shorter than eye; $2^{\text {nd }}$ antennomere globular, $3^{\text {rd }}$ globular, longer than $2^{\text {nd }}$ and shorter than $4^{\text {th }}$, last with apex slightly narrowed. Labrum (Fig. 85) semicircular with long setae. Mandibles (Figs. 143, 144) robust, with one apical and one subapical tooth; penicillus formed by short setae disposed in wide band in whole mesal area; molar area very well developed; dorsal region with carina and moderately long setae. Maxillae (Fig. 172): galea with spatulate setae; last palpomere securiform. Labium (Fig. 182): 
prementum with short setae in front of palpi; postmentum without two long setae, with several moderately long setae. Pronotum (Fig. 237) wider than long, strongly narrowed anteriad; moderately convex; lateral margins carinate; anterior margin strongly notched; hind angles backwardly directed and carinate; carina very distant from lateral margins; median basal tubercle flat; punctuation moderately coarse and moderately dense. Prosternal channel short. Prosternal spine (Fig. 200) with rounded apex and subapical lobe. Borders of mesosternal cavity raised and declivous. Metacoxal plate (Fig. 267) strongly narrowed laterally; free margin with well developed tooth. Tibial spurs very long; tarsomere 3 lamellate beneath. Scutellum subtriangular elongate with posterior margin rounded. Elytra moderately convex, narrowed apicad; striae distinct only laterally; elytra punctuate with striae marked by coarse punctures only laterally.

Male. Tergite 8 elongate, slightly narrowed to apex; distal margin rounded marginate by setae; clothed with microtrichiae. Sternite 8 (Fig. 299) transverse with lateral margins rounded; anterior margins strongly notched; partially translucent with basal sclerite and 2 lateral bands yellowish; lateral setae near angles. Sternite 9: distal half gradually narrow to apex and setous. Tergite 9 (Fig. 361): anterior margin strongly notched at middle, V-shaped; setous near angles; tergite 10 longer than 9 with setae near apex. Aedeagus (Figs. 441, 442) elongate; basal piece longer than parameres; parameres fused ventrally; median lobe gradually narrowed on apical $2 / 3$ and strongly narrowed on distal third; apex of parameres straight with rounded apex.

Female. Tergite 8 elongate, slightly narrowed to apex; distal margin rounded; densely setous. Sternite 8 (Fig. 485) subpentagonal with apex truncate; clothed with setae; spiculum gastrale 7 times sternite length. Ovipositor with stylus; bursa copulatrix (Fig. 511) narrow with spines innerly; opening of colleterial glands with two sclerotized pieces.

Material examined. BRAZIL. São Paulo: Ilha de Buzios, 1 ex. (MZSP); Juquiá, 1 ex. (MZSP), Paranapiacaba, 2 exs. (MZSP), Salesópolis (Estação Biológica de Boracéia), 1 ex. (MZSP), São Paulo (Ipiranga), 1 ex. (MZSP).

Acknowledgements. I am grateful to the Curators and Institutions listed, by loaning material; to Peterson Lásaro Lopes (MZSP) by helping with NDE, TNT and Winclad programs and also by discussions about cladistic analysis; to Claude Girard by providing the facilities in the collection and for hospitality during my visit to MNHN and also loaning material; to Marcelo Duarte da Silva and Antonio Santos Silva (MZSP), by incentive, comments and suggestions; to two anonymous referees by construtive comments and suggestions.

\section{REFERENCES}

Arnett, Jr., R.H. 1962. The beetles of the United States (a manual for identification). Part III: suborder Polyphaga. Washington, The Catholic Univ. Am. Press 46: 497-512.

Basilewsky, P. 1958. Les Dicrepidiinae du Congo belge (Coleoptera Elateridae). Entomologische Arbein aus dem Museum G. Frey 9: $353-477,20$ figs.

Becker, E. 1961. The North American Elaterid types of Otto Schwarz, with a revision of Ctenicera bivittata (Melsheimer) and allies
(Coleoptera). Canadian Entomologist 93: 161-181, 15 figs.

Blackwelder, R. E. 1944. Checklist of Coleopterous insects of Mexico, Central America, the West Indies and South America. Bulletin of the United States National Museum, 185 280-303.

Blackwelder, R. E. \& R. H. Jr. Arnett. 1974. 4. The buprestid beetles, click beetles, fireflies and related groups. 1-60. In: Blackwelder, R. E. \& Arnett, R. H. Jr. (Associates of the NABF Project). Checklist of the beetles of Canada, United States, Mexico, Central America and West Indies (Red Version). Part 1. North American Beetle Fauna Project. The Biological Research Institute of America, Inc. New York.

Blair, K. G. 1927. The Heteromera and some other families of Coleoptera from Polynesia collected on the "St George" Expedition, 1925. Annual Magazine Natural History 9: 161-174.

Blanchard, E \& A. Brullé. 1843. Insectes de lÁmérique Méridionale, recueillis par Alcide D’Orbigny. In: Voyage dans I'Amérique Méridionale 6: 105-222, $32 \mathrm{pl}$.

Blatchley, W. S. 1910. The Coleoptera or beetles of Indiana. Bulletin Indiana Department of Geology and Natural Resources 1: $1-1386$, illus.

Brown, W. J. 1936. Notes on some species of Elateridae (Coleoptera). The Canadian Entomologist 68: 246-252, 4 figs.

Burgeon, L. 1947. Les Olophoeus et Odontonychus (Col. Elat. Dicrepidiinae) du Musée Congo Belge. Revue de Zoologie et de Botanique Africaines 40: 17-39.

Camargo-Andrade, C. A. 1935. O Genero Loboederus. Revista do Museu Paulista 19: 431-442, figs.

Candèze, E. 1859. Monographie des Élatérides. Mémoires de la Societé Royale de Sciences de Liège 14: 1-543, 7 pls.

Candèze, E. 1863. Monographie des Élatérides. Mémoires de la Societé Royale de Sciences de Liège 17: 1-532, 6 pls.

Candèze, E. 1865. Élatérides nouveaux, I. Mémoires de la Academie Belgique 17: 1-65.

Candèze, E. 1869. Abänderungen vergebener Namen. Col. Hefte, No. 5, p. 122.

Candèze, E. 1878. Élatérides nouveaux II. Annales de la Société Entomologique de Belgique (Comptes-rendus) 21: 1i-cxliii.

Candèze, E. 1887. Note XVIII. Description d'un Élatéride nouveau de l'Amérique Méridionale. Notes from the Leyden Museum 9: 188 .

Candèze, E. 1891. Catalogue Méthodique des élatérides connus en 1890. Liège: H. Vaillant-Carmanne. xii $+246 \mathrm{p}$.

Candèze, E. 1893. Élatérides Nouveaux, $5^{\text {e }}$ fascicule. Mémoires de la Societé Royale des Sciences de Liège 18: 1-76.

Candèze, E. 1894. Elatérides recueillis par M. le docteur E. Modigliani aux bords du lac Toba à Sumatra, de Novembre 1890 a Mars 1891. Annali del Museo civico di Storia Naturali Giacomo Doria 14: $484-504$.

Candèze, E. 1900. Élatérides nouveaux. Septième fascicule. Annales de la Société Entomologique de Belgique 44: 77-101.

Casari, S.A. 2002. Review of the genus Chalcolepidius Eschscholtz, 1829 (Coleoptera, Elateridae, Agrypninae). Revista Brasileira de Entomologia 46: 263-428.

Casari, S. A. 2004. Revision of Loboederus Guérin-Méneville (Coleoptera, Elateridae, Elaterinae, Ampedini). Revista Brasileira de Entomologia 48: 459-466.

Casari, S. A. 2005. Revision of the genus Blauta LeConte (Coleoptera, Elateridae, Elaterinae, Ampedini, Dicrepidiina). Revista Brasileira de Entomologia 49: 448-452.

Castelnau, F. L. N. C. Laporte Comte de. 1840. Histoire naturelle des animaux articulés. Paris, v. 1, $324 \mathrm{p}$.

Champion, G. C. 1894-1895. Biologia Centrali-Americana. Insecta. Coleoptera. Serricornia. Elateridae. London, Taylor \& Francis. Vol. 3, part 1, pp. 258-296 (1894), pp. 297-440 (1895).

Chassain, J.1979. Contribution a la connaissance de la faune entomologique des Antilles françaises (Col. Elat.) (1er note). Bulletin de la societé Entomologique de France 84: 62-65.

Chevrolat, L. A. A. 1867. Coléoptères de 1'Ile de Cuba. (Suite) Notes, synonymies et descriptions d'espèces nouvelles. Septième mémoire 
Famille des buprestides, throscides, eucnémides et élaterides. Annales de la Societé Entomologique de France 7: 571-616.

Cobos, A. 1970. Contribution à la faune du Congo (Brazzaville). Mission A. Villiers et A. Descarpentries. 94. Coléoptères Throscidae, Eucnemidae et Elateridae. Bulletin Institut Fondamental d'Afrique Noire 32: 130-250, 96 figs.

Costa, C. 1968. Descrição de uma espécie nova de Anoplischius (Coleoptera, Elateridae). Papéis Avulsos de Zoologia 21: 161164.

Costa, C. \& S. A. Casari-Chen. 1990. Notas sobre o gênero Achrestus Candèze, 1859 (Elateridae, Dicrepidiinae). Revista Brasileira de Entomologia 34: 303-306.

Crowson, R. 1960. On some new characters of classificatory importance in adults of Elateridae (Coleoptera). Entomologist's Monthly Magazine 96(1960)(1961): 158-161.

Dejean, P. F. M. A. 1833. Catalogue des coléoptères de la collection de M. le comte Dejean, livr. 2, p. 97-176. Paris.

Dolin, V. G. 1975. Wing of click beetle (Col. Elat.) and importance for the taxonomy of the family. Zoologicheskii zhurnal 54: 16181633 .

Eschscholtz, J. F. 1829. Eintheilung der Elateriden in Gattungen. Entomologisches Archiv 2: 31-35.

Fall, H. C. 1925. New species of Coleoptera or recent discovery. Bulletin of the Brooklyn Entomological Society 20: 180183.

Fischer, C. R. 1823. Lettre à Hennig sur le physodactyle. Mémoires de la Société Impériale des Sciences Naturales de Moscou 6: 301-304

Fleutiaux, E. 1892. Note sur les Physodactylyni. Annales de la Societé Entomologique de France 61: 403-411.

Fleutiaux, E.1902a. Description de quelques élatérides nouveaux de ma collection (Col.) (1er mémoire). Bulletin de la Societé Entomologique de France 1902: 112-116.

Fleutiaux, E. 1902. Description de quelques élatérides nouveaux de ma collection (Col.) (2e mémoire). Bulletin de la Societé Entomologique de France 1902: 137-138.

Fleutiaux, E.1905. Voyage de M. Maurice Maindron dans 1’Inde Méridionale (1901) 8e mémoire. Annales de la Societé Entomologique de France 74: 318-330.

Fleutiaux, E.1907. Revision des Elateridae du Chili. Revista Chilena de Historia Natural 11: 160-232.

Fleutiaux, E. 1911. Revision des Trixagidae, Melasidae et Elateridae (Col.) des Antilles françaises. Annales de la Societè Entomologique de France 80: 235-264.

Fleutiaux, E. 1912. Description d'un genre nouveau et d'une espèce nouvelle d’Elateridae [Col.] de la Republique Argentine. Bulletin de la Societé Entomologique de France 1912: 264.

Fleutiaux, E.1918. Nouvelles contributions a la faune de 1'Indo-chine française [Coleoptera serricornia]. Annales de la Societé Entomologique de France 87: 175-278.

Fleutiaux, E. 1919. Insectes Coléoptères XIII. Elateridae, Trixagidae et Melasidae. Pp.1-119. In: Voyage de Ch. Alluaud et R. Jeannel em Afrique orientale (1911-1912). Résultats Scientifiques. Coléoptères XIII, pp 1-120. Paris, Lhomme.

Fleutiaux, E. 1922.Coléoptéres Élatérides. In: Voyage de M. le Baron Maurice de Rothschild em Ethiopie et em Afrique Orientale Anglaise (1904-1905). Paris, Résultats Sientifiques. Animaus articulés 2: 288-598.

Fleutiaux, E. 1928. Les Élatérides de 1'Indochine Française (Catalogue raisonné). Encyclopedie Entomologique Serie BI, Coleoptera 3: 103-107, 2 figs.

Fleutiaux, E. 1932. Contributions à l'étude de la faune du Mozambique. Voyage de M. P. Lesne (1928-1929). 6e note - Coléoptères, Elateridae. Memorias e Estudos do Museu Zoológico da Universidade de Coimbra 55: 5-27.

Fleutiaux, E. 1935a. Coleoptera V. Elateridae. Mission Scientifique de L'Omo 2: 193-217.

Fleutiaux, E. 1935b. Eucnemididae et Elateridae nouveau. Bulletin et Annales de la Societé Entomologique de Belgique 75: 300305.
Fleutiaux, E. 1935c. Description d’Eucnemididae et Elateridae nouveaux provenant du Corydon Memorial Museum de Nairobi, Kenya Colony. Journal of the East Africa and Uganda Natural History 12 (1934)(1935): 90-117.

Fleutiaux, E. 1936. Les Elateridae de 1'Indochine Française (6e partie). Annales de la Societé entomologique de France 105: 279300 .

Fleutiaux, E. 1942. Entomological results from the Swedish Expedition to Burma and British India. Coleoptera: Elateridae recueillis par René Malaise. Arkiv för Zoologi, Stockholm 33A: 1-24, 39 figs.

Fleutiaux, E. 1945. Mission P. Lepesme R. Paulian et A. Villiers au Cameroun. Coléoptères Elateridae. Bulletin du Muséum d'Histoire Naturelle 13: 38-44.

Fleutiaux, E. \& A. Salle. 1889. Liste des coléoptères de la Guadeloupe et descriptions d'espèces nouvelles. Annales de la Societè Entomologique de France 9: 351-484.

Gemminger, M. \& E. von Harold. 1869. Catalogus coleopterorum hucusque descriptorum synonymicus et systematicus, v. 5, p. 1347-1608. Monachii

Germar, E. F. 1839. Ueber die Elateriden mit häutigen Anhängen der Tarsenglieder. Zeitschrift für Entomologie 1: 193-236.

Girard, C. 1971. Les Coléoptères Elateridae de Lamto (Côte d 'Ivoire). Bulletin de I’IFAN, 33 sér.A: 549-650.

Girard, C. 1972. Contribution à l'étude des Elateridae de l'Afrique noire [Col.]. Bulletin de la Societé Entomologique de France 77: $276-283$.

Girard, C. 1974a.Contribution à l'étude du genre Propsephus Hyslop (1) (Coleoptera, Elateridae, Dicrepidiinae). Annales de la Societé Entomologique de France 10: 207-218.

Girard, C. 1974. Contribution à l'étude du genre Olophoeus (Coleoptera, Elateridae, Dicrepidiinae). Annales de la Societé Entomologique de France 10: 721-727.

Girard, C. 1975. Les Elateridae (Coleoptera) récoltés par J. L. Amiet en Mauritanie. Bulletin Institut Fondamental d'Afrique Noire 37: 801-811.

Girard, C. 1976. Contribution a l'étude (1) du genre Propsephus Hyslop (Col. Elateridae Dicrepidinae). Annales de la Societé Entomologique de France 12: 419-431.

Girard, C. 1980. Contribution a l'étude du genre Propsephus Hyslop (Col., Elateridae, Dicrepidiinae). Annales de la Societé Entomologique de France 16: 209-219.

Girard, C. 1985. Deux nouvelles espèces de Dicrepidiinae du genre Rhinopsephus Schwarz (Coleoptera, Elateridae). Nouvelle Revue d'Entomologie 2: 75-78.

Girard, C. 1985 (1986). Quatre nouveaux Elateridae de la forêt de Taï (Côte d'Ivoire) [Coleoptera]. Revue Française d'Entomologie 7: 331-336.

Girard, C. 1986. Sept nouvelles espèces de Dicrepidiinae du genre Propsephus Hyslop (Coleoptera, Elateridae). Nouvelle Revue d'Entomologie 3: 473-483.

Girard, C. 1989. Étude de Propsephus afrotropicaux et description de six espéces nouvelles (Coleoptera, Elateridae). Revue de Zoologie Africaine 103: 329-346.

Girard, C. 1991a. Étude des peuplements d’Élatéridae (Coleoptera) des savanes du Mont Nimba (Guinee, Côte-d'Ivoire), et descriptions de taxa nouveaux. Annales de la Societé Entomologique de France 27: $323-360$.

Girard, C. 1991b. Étude des Propsephus afrotropicaux décrits par E. Candèze (Col. Elateridae). Nouvelle Revue d'Entomologie 8: 307-322.

Girard, C. 1996. Six Propsephus nouveaux de la région afrotropicale (Coleoptera, Elateridae). Bulletin de la Societé Entomologique de France 101: 419-430.

Girard, C. 2003a.Étude des peuplements d’Elateridae (Coleoptera) de la région du mont Nimba et descriptions de taxons nouveaux. In: Lamote M. \& Roy R. (eds), Le peuplement animal du mont Nimba (Guinée, Côte d'Ivoire, Liberia). Mémoires du Muséum national d'Histoire naturelle 190: 393-549, Paris.

Girard, C. 2003b. Étude de quelques especes afrotropicales du genre 
Pantolamprus Candèze et du genre Xantholamprus Fleutiaux et description d'une espèce nouvelle (Coleoptera, Elateridae, Dicrepidiini). Nouvelle Revue d'entomologie 20: 75-94.

Golbach, R. 1953. Ovipalpus schajovskoii sp. n. (Col. Elat.). Acta Zoologica Lilloana Tucuman 13: 387-390, 4 figs.

Golbach, R. 1990. Paraloboderus glaber genero y especie nueva de Elateridae (Col.). Acta Zoologica Lilloana 39: 27-30.

Golbach, R. 1994. Elateridae (Col.) de la Argentina. Historia, Catálogo actualizado hasta 1991 inclusive y clave de subfamilias y de géneros de Centro y Sudamérica. Opera Lilloana 41: 1-48.

Goloboff, P., 1993. Estimating character weights during tree search. Cladistics 9: 83-91.

Goloboff, P., J. Farris \& K. Nixon. 2003. T.N.T. Tree analysis using new technology. Program and documentation, available from the authors and www.zmuc.dk/public/phylogeny.

Guérin-Méneville, F. E. 1831. [Description of Loboederus monilicornis]. Magasin de Zoologie 1: 9.

Guérin-Méneville, F. E. 1938. Insectes du voyage de la Favorite. Magasin de Zoologie 8: 1-80, pls 225-238.

Gurjeva, E. L. 1974. Thoracic structure of click beetles (Coleoptera, Elateridae) and the significance of the structural characters for the system of subfamily. Entomologicheskoye Obozreniye 53: 96113.

Heyne, A \& O. Taschenberg. 1908. Die exotischen Käfer in Wort und Bilt, 27 Lieferungen. Leipzing, 262p., 39 pl.

Hyslop, J. A. 1917. The phylogeny of the Elateridae based on larval characters. Annals of the Entomological Society of America 10: $241-263$.

Hyslop, J. A. 1921. Genotypes of the elaterides of the world. Proceedings of the United States National Museum 58: 621680

Jacquelin du Val, P. N. C. 1857. Insectes. Ordre des coléoptères, Lin. In: Sagra, Histoire ...de 1'Ile de Cuba, v. 7: 137-328.

Johnson, P. J. 2002a. 58. Elateridae. P. 160-173. In: Arnett, Jr., R. H., M. C. Thomas, P. E. Skelley \& J.H. Frank (eds.). American Beetles. Polyphaga: Scarabaeoidea through Curculionoidea. V. 2, CRC Press, 861 p.

Johnson, P. J. 2002b. Lectotype designations for Elateridae (Coleoptera) described by George C. Champion in the Biologia CentraliAmericana. Dugesiana 9: 15-46.

Kishii, T.1990. Taiwanese Elateridae collected by Mr. M. Yagi, with the descriptions on some new taxa (Coleoptera). Entomological Review of Japan 45: 11-27.

Kishii, T.1999. A study on the elaterid beetles of Shibata Collection from Taiwan, 7 (Col., Elat.). On the subfamily Elaterinae: tribe Dicrepidiini. Entomological Review of Japan 54: 5-9.

Lacordaire, J. T. 1857. Genera des Colèoptères. Paris, Librairie Encyclopédique de Roret, v.4, 579 p.

Latreille, P. A. 1834. Distribution méthodique et naturelle des genres de diverses tribus d'insectes coléoptères, de la famille des serricornes. Annales de la Societé Entomologique de France 3: 113-170.

Laurent, L. 1965. Les Elateridae de Belgique (1re Partie). Bulletin de I'Institut Agronomique et des Stations de Recherches de Gembloux 33: 245-290.

LeConte, J. L. 1853. Revision of the Elateridae of the United States. Transactions of the American Philosophical Society 10: $363-$ 403.

LeConte, J. L. 1884. Short studies of North American Coleoptera (no 2). Transactions of the American Entomological Society 12: $1-32$.
Lesne, P. 1940. Remarques sur divers Élatérides [Col.]. Bulletin de la Société Entomologique de France 45: 33-40.

Lewis, G. 1894. On the Elateridae of Japan. Annals and Magazine of Natural History 13: 182-201.

Murray, A. 1878. List of the Coleoptera from Old Calabar, on the West Coast of Africa. Hillside Books, 221, 4 pls.

Nixon, K. C. 2002. Winclada (BETA) ver. 1.00.08. Published by the author, Ithaca, NY.

Nixon, K. C. \& J. M. Carpenter. 1993. On out groups. Cladistics 9: 413-426.

Page, R. 2001. NDE (Nexus Data Editor for Windows) ver. 0.5.0. Published by the author, Glasgow, United Kingdom.

Perty, J. A. M. 1830. Insecta Brasiliensa. In: Delectus animalium articulatorum ... (fasc. 1), pp. 1-60, illus.

Quelle, F.1955. Üeber Sexual-Armaturen weiblicher Elateriden. Elateriden-Studien 3 Deutsche Entomologische Zeitschrift 2 : 152-157.

Schenkling, S. 1925. Elateridae I. Pars 80. In: Coleopterorum Catalogus auspiciis et auxilio W. Junk. Berlin, W. Junk. 263 p.

Schwarz, O. C. E. 1899. Beitrag zur Kenntnifs der Elateriden-Gattungen Psephus Cand. und Olophoeus Cand. nebst Beschreibung einiger neuer Arten. Deutsche Entomologische Zeitschrift: 65-80.

Schwarz, O. C. E. 1900. Neue exotische Elateriden. Deutsche Entomologische Zeitschrift: 305-358.

Schwarz, O. C. E. 1901.Verzeichnifs der von Hrn. Dr. Horn auf Ceylon gesammelten Elateriden nebst Beschreibung neuer Arten. Deutsche Entomologische Zeitschrift 1901: 17-38.

Schwarz, O. C. E. 1902. Aenderung des Gattungsnamens. Deutsche Entomologische Zeitschrift p. 126.

Schwarz, O. C. E. 1906. Coleoptera Fam. Elateridae. Fasc. 46A p. 1112. In: P. Wystman (ed.). Genera Insectorum. Bruxelles, P. Wystman.

Smith, J. W. \& W. R. Enns. 1977. The click beetle subfamilies Agrypninae, Pyrophorinae, and Melanotinae (Coleoptera: Elateridae) in Missouri - Part I. Journal of the Kansas Entomological Society 50: 436-468.

Solier, A. J. J. 1851. Orden III. Coleopteros. In: Gay, Historia física y politica de Chile 5: 1-285.

Steinheil, E. 1875. Beiträge zur Kenntniss der Fauna von NeuGranada (Trixagidae, Eucnemidae, Elateridae). Col Hefte, 14: $107-136$.

Stibick, J. N. L. 1979. Classification of the Elateridae (Coleoptera). Relationships and classification of the subfamilies and tribes. Pacific Insects 20: 145-186.

Suzuki, W. 1988. Record of Ischiodontus kawaii in Chiba Prefecture, central Japan. Elytra 16: 6.

Van Zwaluwenburg, R. H. 1928. Elateridae. Insects of Samoa. The British Museum (Natural History) 4: 111-124, 10 figs.

Van Zwaluwenburg, R. H. 1934. Two new Elateridae from Melanesia. Annals and Magazine of Natural History 10: 262-264.

Van Zwaluwenburg, R. H. 1936. New records and new species of Elaterid beetles from Melanesia. II. Annals Magazine of Natural History 17: $368-376$

Van Zwaluwenburg, R. H. 1959. Some type designations with notes on Pacific Elateridae (Coleoptera). Pacific Insects 1: 347-412, 2 pls, 3 figs.

Vats, L. K. \& R. L. Chauhan. 1992. Two new species of Adiaphorus Candèze from North India (Coleoptera: Elateridae). Journal of Entomological Research: 177-180. 